$$
\begin{gathered}
\text { UNIVERSIDADE DE SÃO PAULO } \\
\text { ESCOLA DE COMUNICAÇÕES E ARTES } \\
\text { PROGRAMA DE PÓS-GRADUAÇÃO EM CIÊNCIAS DA COMUNICAÇÃO }
\end{gathered}
$$

\title{
Produção Partilhada e Reticularidade Fílmica
}




\section{CAIO DE SALVI LAZANEO}

\section{Produção Partilhada e Reticularidade Fílmica}

Tese apresentada à Escola de Comunicações e Artes da Universidade de São Paulo para obtenção do título de Doutor em Ciências da Comunicação

Área de concentração: Teoria e Pesquisa da Comunicação.

Linha de Pesquisa: Comunicação e Ambiências em Redes Digitais

Orientador: Prof. Dr. Sérgio Bairon Blanco Sant'Anna.

São Paulo

2017 
Autorizo a reprodução e divulgação total deste trabalho, por qualquer meio convencional ou eletrônico, para fins de estudo e pesquisa, desde que citada a fonte.

LAZANEO, Caio de Salvi.

PRODUÇÃO PARTILHADA E RETICULARIDADE FÍLMICA / Caio de Salvi

Lazaneo - Orientador: Prof. Dr. Sérgio Bairon Blanco Sant’Anna. - São Paulo, 2017.

$217 \mathrm{f}$.

Tese (Doutorado) - Universidade de São Paulo, Escola de Comunicações e Artes, 2017.

1. Produção Partilhada do Conhecimento 2. Reticularidade fílmica 3. Hipermídia. 4.

Montagem. I. BAIRON, Sérgio. II. PRODUÇÃO PARTILHADA E

RETICULARIDADE FÍLMICA 
LAZANEO, Caio de Salvi. Produção Partilhada e Reticularidade Fílmica. Tese apresentada à Escola de Comunicações e Artes da Universidade de São Paulo para obtenção do título de Doutor em Ciências da Comunicação. Área de concentração: Teoria e Pesquisa em Comunicação.

Aprovado em:

\section{Banca examinadora}

Prof. Dr. Instituição:

Julgamento: Assinatura:

Prof. Dr. Instituição:

Julgamento: Assinatura:

Prof. Dr. Instituição:

Julgamento: Assinatura:

Prof. Dr. Instituição:

Julgamento: Assinatura:

Prof. Dr. Instituição:

Julgamento: Assinatura: 
A Andrea Tonacci

pela humanidade profunda e inventiva 


\section{AGRADECIMENTOS}

Agradeço a minha pequena Ceci, nascida no percurso da construção desta pesquisa. Nestes quase quatro anos em que tive a oportunidade de renascer ao seu lado tornei-me alguém muito melhor. Sou infinitamente grato ao que você, pequena, proporcionou-me no aprendizado diário de observar e partilhar de sua singularidade e sua poesia da infância, um conhecimento que espero nunca desaprender. É por você sempre!

Agradeço à Mariana, por toda parceria, generosidade... por toda a beleza também de seu nascimento como mãe e por dividi-lo comigo. Por oferecer a calma e a paciência para acalentar a angústia, e também o amor sempre que possível... por um saber que vem de longe e que é maduro e que sabe sempre rir da vida.

Agradeço aos meus pais e irmãs pela confiança, apoio e amor, sempre resoluto em todas as minhas viagens... Sejam elas acadêmicas, de vida, das incertezas. Enfim, por nunca terem economizado o afeto nem um só momento.

Agradeço aos amigos Juanahú Iny, Divino Tserewahú e Paulinho Kadojeba, parceiros de Produção Partilhada. Em especial também à comunidade Hawalo. Mareciru, Iexika, Herenaki, Malawiru, a acolhedora família de Jua que é também minha família da Ilha do Bananal.

Agradeço ao meu orientador Prof. Dr. Sérgio Bairon pela amizade, generosidade, acolhimento e, sobretudo, por ensinar-me a arte da escuta e por ensinar-me a perder-me no caminho do equívoco como compreensão.

Agradeço à Prof. Dra. Aivone Carvalho pela amizade da vida, pelos museus vivos, por lutar sempre ao lado das causas boas e significativas, e, por fim, pelas tantas contribuições no exame de qualificação.

Agradeço ao Prof. Dr Victor Aquino por partilhar suas inúmeras histórias de vida e outras tantas contribuições no exame de qualificação.

Agradeço ao prof. Dr. Massimo di Felice, primeiro orientador no doutorado, por quem tenho grande respeito e admiração.

Agradeço aos tantos mestres e mestras, educadores, sujeitos diversos, griôs, com os quais tive a oportunidade de aprender na vida, da maternidade ao doutorado, ao dividirem seus conhecimentos, valores, afetos e contribuírem substancialmente na minha caminhada. $O$ conhecimento, pois, é a espiral da vida. 
Agradeço aos meus colegas de CEDIPP, em especial Jonathas Beck e Érica Nering pelas trocas, conselhos, risos e amizade.

Agradeço aos meus amigos Caio Luiz e Yudji Oliveira por terem participado com tanto empenho e criatividade do trabalho de campo na aldeia Hawalo.

Agradeço ao escritório da Funai de São Félix do Araguaia, em especial ao chefe de posto Kohalue, pelo auxílio em nosso transporte da aldeia Hawalo à aldeia Fontoura.

Agradeço, por fim, à Coordenação de Aperfeiçoamento de Pessoal de Nível Superior (CAPES) pelo financiamento e apoio a esta pesquisa de março de 2014 a fevereiro de 2017. 


\section{RESUMO}

Esta tese apesenta um estudo focado em dois eixos principais: No primeiro, denominado "Reticularidade Fílmica", enfatizamos relações entre as novas medias (MANOVICH, 2001), o documentário digital interativo (GAUDENZI, 2013), a noção de criação de banco de dados fílmicos em Vertov (BAIRON, 2008, MANOVICH, 2001) e a concepção de cinematismo em Eisenstein (BORDWELL 2005, MANOVICH, 2001). Compreendemos a "Reticularidade Fílmica" enquanto um processo de produção e montagem audiovisual em que a aleatoriedade dos acontecimentos em uma ambiência hipermidiática, pode colaborar na construção da compreensão de algo, sobretudo no interior fílmico interativo. 0 segundo eixo compreende o que temos denominado "Produção Partilhada do Conhecimento" (LAZANEO, 2012), onde propomos uma aproximação possível com outros aportes teórico-metodológicos em iniciativas como a Antropologia Partilhada de Jean Rouch (RIBEIRO, 2007; ROUCH, 1995; SZTUTMAN, 2004), a Pedagogia Griô (PACHECO, 2015), a Pesquisa-ação (THIOLLENT, 2011), bem como a noção de dupla ruptura epistemológica" (SANTOS, 2002). A Produção Partilhada envolve processos de produção do conhecimento a partir da inter-relação entre comunidade e universidade. Aqui tratamos especificamente do trabalho desenvolvido junto ao realizador Juanahú Iny, na aldeia Hawalo, da etnia Iny (karajá), localizada no município de Lagoa da Confusão - TO. Durante o trabalho de campo nesta comunidade foram realizados produtos audiovisuais com vistas a construção de ambiências reticulares, descritos nos "Diários de "Partilha".

Pretende-se, deste modo, propor um subsídio dialógico que compreende a Produção Partilhada como um pressuposto teórico-metodológico à Reticularidade Fílmica na lide com comunidades de tradição oral para as quais o texto científico, na matriz verbal, representa um barreira epistêmica. Assim, defendemos o desenvolvimento de ambientes em Reticularidade Fílmica com base na Produção Partilhada, como uma dimensão apropriada a criação de novas epistemologias em Hipermídia.

Palavras-chave: Produção Partilhada do Conhecimento; Reticularidade Fílmica; Hipermídia; Montagem. 


\begin{abstract}
This thesis presents a study focused on two main axes: In the first, called "Filmic Reticularity," we emphasize relations between the new media (MANOVICH, 2001), the digital interactive documentary (GAUDENZI, 2013), the Vertov's notion of database creation (BAIRON, 2008, MANOVICH, 2001), and the conception of cinematism in Eisenstein (BORDWELL 2005, MANOVICH, 2001). We understand "Filmic Reticularity" as a process of audiovisual production and montage in which the randomness of events in a hypermiditic environment can collaborate in the construction of the understanding of something, especially in the interactive filmic interior. The second axis comprises what we have called "Shared Production of Knowledge" (LAZANEO, 2012), where we propose a possible approximation with other theoretical-methodological contributions in initiatives such as Jean Rouch's "Shared Anthropology" (RIBEIRO, 2007; ROUCH, 1995; SZTUTMAN, 2004), "Griô Pedagogy" "(PACHECO, 2015), "Action Research" (THIOLLENT, 2011), as well as the notion of "double epistemological rupture" (SANTOS, 2002). Shared Production involves processes of knowledge production based on the interrelation between community and university. Here we cover the work developed with the director Juanahú Iny, in the Hawalo village, of the Iny ethnic group (karajá), located in the municipality of Lagoa da Confusão - TO. During the field work in this community, audiovisual products were created objectfying the construction of reticular ambiences, described in the "Diaries of Sharing." We intend, in this way, to propose a dialogical subsidy that includes the Shared Production as a theoretical-methodological assumption to the Filmic Reticularity in the dealing with communities of oral tradition for which the scientific text, in the verbal matrix, represents an epistemic barrier. Thus, we defend the development of environments in Filmic Reticularity based on Shared Production, as an appropriate dimension to the creation new epistemologies in Hypermedia.
\end{abstract}




\section{Lista de figuras}

FIGURA 1 - Caio Lazaneo, Cecília Morello Lazaneo, Juanahú Iny e Andrea Tonacci ....................19

FIGURA 2 - Juanahú Iny e Caio Lazaneo trabalham na edição dos filmes Iny ......................29

FIGURA 3 - Três frames de "Pillow book" de Peter Greenaway. Montagem espacial na sobreposição de camadas audiovisuais no mesmo quadro................................................ 46

FiguRA 4 - Les glaneurs, de Agnes Varda................................................ 55

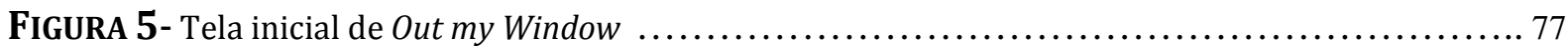

FIGURA 6 - One Highrise. Every window, a diferente city. Entorno principal da hipermídia sugere um prédio com três pavimentos (distribuído com quatro histórias / habitações nos dois primeiros andares e 5

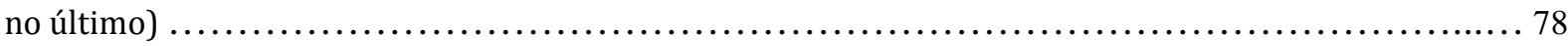

FIGURA 7 - Nesta planta, estão reunidas as quatro imagens reticulares (1. Highrise Squat / 2. Everybody's baby / 3. Pictures of my past / future e 4. Neighbours) que acionam os quatro filmes dentro da habitação

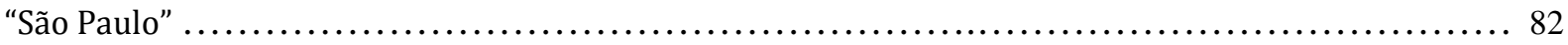

FIGURA 8 - Os quatro ambientes da habitação São Paulo: Fora / Dentro / Fora / Dentro, construídos a partir da colagem de imagens manipuladas. Em cada um, há uma interação possível a partir do clique nas imagens reticulares. Cada ambiente, por sua vez, se relaciona ao outro em circularidade. Arrastando, horizontalmente, cada tela/ambiente - seja em direção à esquerda ou à direita - chegamos à próxima. "Dentro" e "fora" se confundem em uma atmosfera que busca reconstruir "the towers in the world, the world in the towers" (as torres no mundo e o mundo nas torres) . ............................ 82

FIGURA 9 - 0 filme $360^{\circ}$ permite que nos movimentemos junto com a roda que, por sua vez, movimenta-se

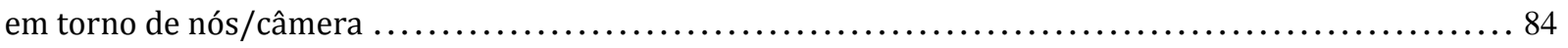

FIGURA 10 - Essa planta mostra as imagens reticulares que acionam os vídeos musicais $360^{\circ}$ sucessivamente em Havana, Amsterdam e Toronto. Em Amsterdam e Toronto, as imagens são dos próprios protagonistas das habitações; em Havana, do microfone do estúdio . ........................... 84

FIGURA 11 - "Monumento às bandeiras", de Victor Brecheret, tingido de tinta vermelha em intervenção guarani

FIGURA 12 - "26 de setembro de 2013, 6 h30 am. Nós indígenas guarani de todas as aldeias de São Paulo fechamos a rodovia batizada com o nome de assassinos de índios"

FGURA 13 - Avistamos uma enorme roda onde os guarani, de mãos dadas, cantam e dançam, enquanto uma fogueira arde e cria uma simbólica cortina de fumaça que torna opaca a visão dos guarani para os brancos do lado de lá e vice-versa 96

FGURA 14 - Plano e contra-plano, próximo à manifestação e distante dela 98

FIGURA 15 - Comentário na página do youtube do filme "Rodovia Rojoko - 0 dia em que paramos a Bandeirantes - CGY" 
FIGURA 16- 11 frames dos jovens guarani-mbya que, em pró-filmia, explicam olhando para a câmera o motivo pelo qual ocuparam a rodovia dos bandeirantes. 101

FIgURA 17- Três hiperlinks nos dão as possibilidades reticulares ao final do vídeo Manifesto: Por que fechamos a Bandeirantes?

FiguRA 18- Plano final do vídeo "Mensagem à bancada ruralista", oferece três hiperlinks...................................................................... 102

FIGURA 19- Fluxograma da reticularidade fílmica guarani ................................... 108

FIGURA 20- Página do financiamento coletivo do filme "Martírio", no Catarse

FigURA 21 - Paulinho Ecerae Kadojeba reflete sobre a não realização do documentário sobre o ritual fúnebre bororo 134

Figura 22 - Espiral da Produção Partilhada do Conhecimento 138

FigURA 23 - Juanahú distribui o dvd "Berahatxi-rbi Olodu Mahadu" para o menino Hariteburé e para seu amigo Uriwau na aldeia Hawalo

FiguRA 24- 0 velho Kurania mostra brincos e artesanatos que confecciona. A foto ao lado mostra o pequeno banco que o homem, de grande sabedoria, costuma se sentar 159

FIGURA 25 - Crianças e mulheres se reúnem para assistir à Berahatxi-rbi Olodú Mahadu, primeiro filme de Juanahú

FIGURA 26 - Pôr-do-sol da Aldeia JK, Ilha do Bananal

FIGURA 27 - Caio Luiz, Juanahú, Caio Lazaneo e Yudji Oliveira. Conversa da equipe sobre o filme em andamento 174

FigURA 28 - Da esquerda para direita Myralu Derahawi (tia-avó), as crianças e Koixaru (avó do bebê), na casa onde se dera a oferta (no caso sabonetes) aos brotyré.

FiguRA 29 - Chegada dos Aruanãs à Hawalo 186

FIGURA 30 - Ritxoco na beira do rio Araguaia 187 


\section{Índice de poesias}

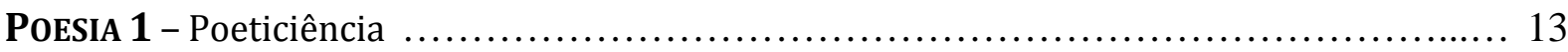

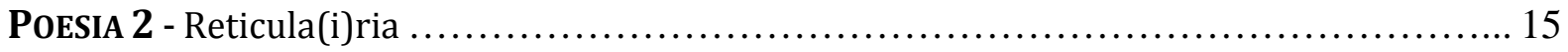

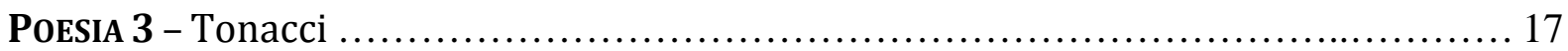

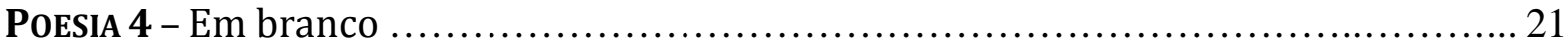

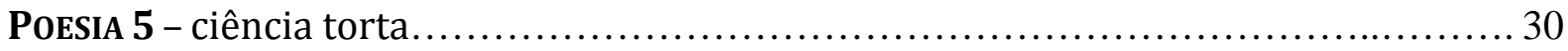

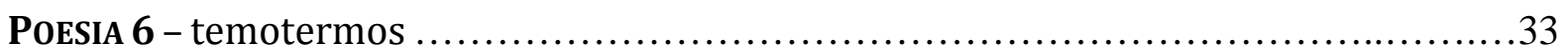

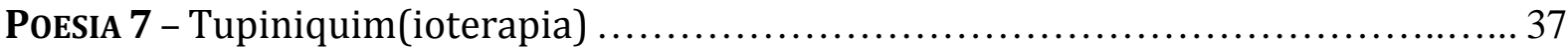

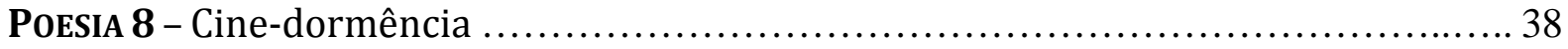

PoEsia 9 - Cinespiral .......................................................... 40

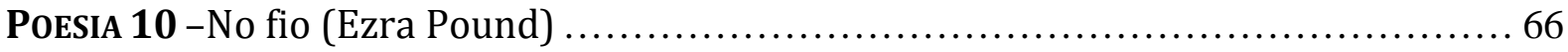

PoEsIA 11 - Ancestral Aleautoralidade ............................................ 70

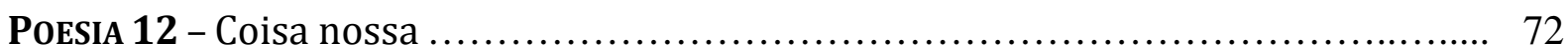

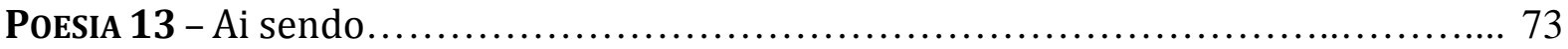

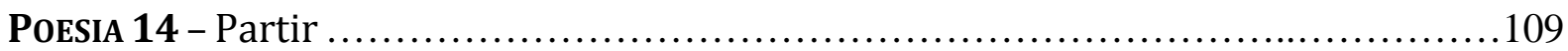

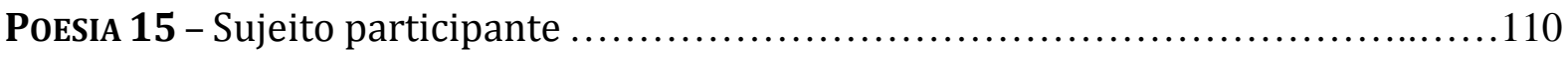

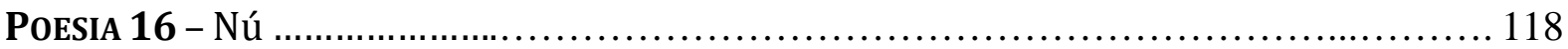

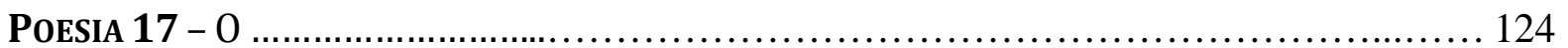

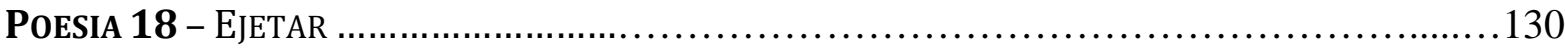




\section{SUMÁRIO}

UM DESENHO LIVRE .......................................................... 13

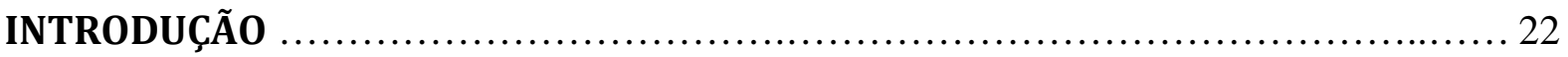

\section{CAPÍTULO I}

RETICULARIDADE FÍLMICA

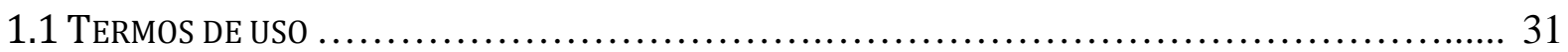

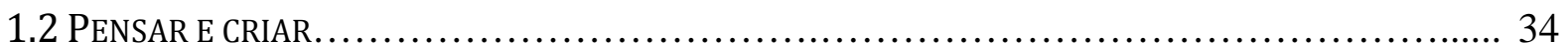

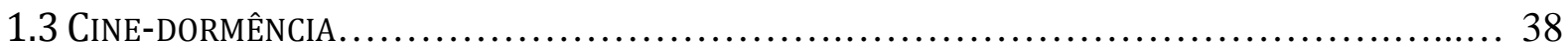

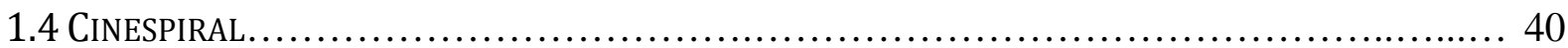

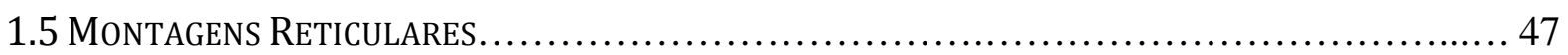

1.6 A RETICULARIDADE NO DOCUMENTÁRIO DIGITAL INTERATIVO ........................... 56

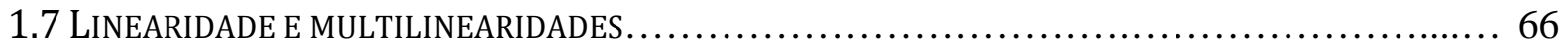

1.8 Da Reticularidade Fílmica À ProduÇão Partilhada do Conhecimento................... 70

\section{CAPÍTULO II}

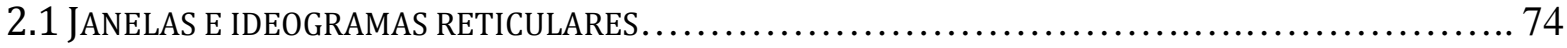

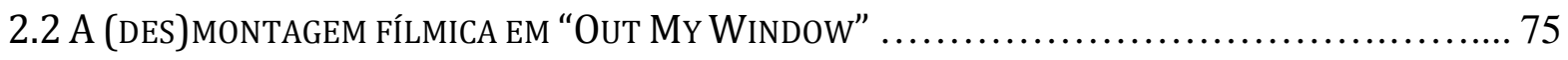

2.3 UM PRÉDIO, CADA JANELA, UMA CIDADE DIFERENTE .................................. 76

2.4 JANELAS DESMONTADAS, DE FOR A DA JANELA PARA A CASA DE VIDRO ......................... 84

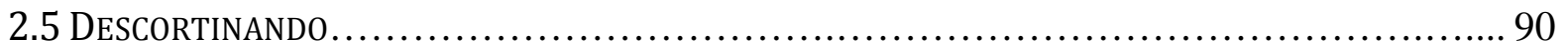

2.6 RETICULARIDADES GUARANI...................................................... 92

2.7 DEIXOU DE SER PEDRA E SANGROU............................................. 93

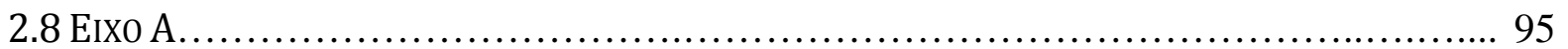

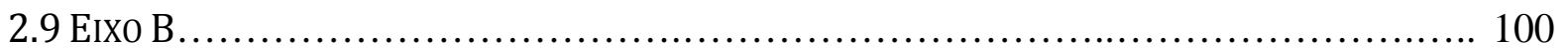

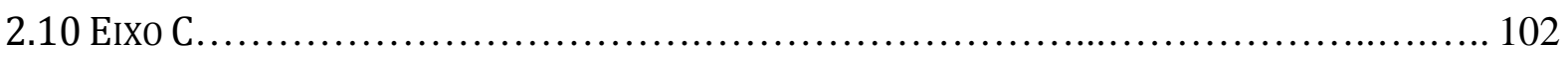

2.11 Reticularidade guarani: Uma Media xondaro .................................. 104

\section{CAPÍTULO III}

3.1 AS BASES RETICULARES DA ANTROPOLOGIA PARTILHADA ............................. 110

3.2 A Pedagogia Griô e a Produção Partilhada ........................................ 123

3.3 PESQuisa-AÇÃo E A ProduÇão PartilHadA ............................................ 130

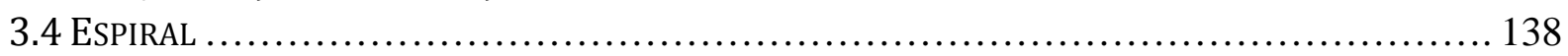




\section{CAPÍTULO IV}

4.1 VIAGEM A HAWALO

139

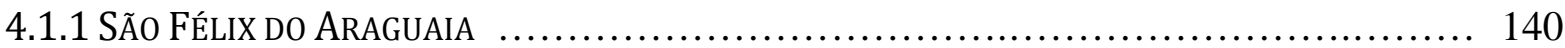

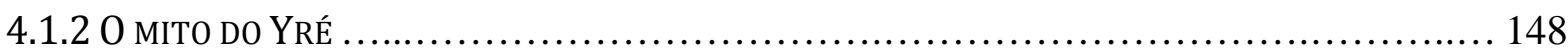

4.1.3 CALMA QUE o BRASIL É NOSSO.................................................... 162

4.1.4 EU ANDO RESPEITANDO A CULTURA .................................................. 171

4.1 .5 ALDEIA FONTOURA ........................................................... 183

4.1.6 DE Volta A HaWALO, ChEgaram os ARUANãs.......................................... 185 


\title{
Um desenho livre
}

\author{
poeticiência \\ Haveria, pois, \\ alguma ineficiência \\ em traduzir a ciência \\ em poesia? \\ Ou haveria, pois, \\ na poesia, \\ uma potência \\ de sabedoria?
}

Guardo comigo uma saborosa lembrança, afetivamente conjugada aos dias onde, de fato, a memória consegue alcançar passagens efetivamente mais "sólidas". Era o tempo onde eu, já com algum domínio da linguagem oral (na casa dos meus 4 ou 5 anos), aguardava ansiosamente pelo prazeroso momento em que a professora da escolinha anunciava: “- Peguem uma folha de papel em branco, hoje faremos um desenho livre!" A ansiedade era tamanha que por vezes nem sempre a folha pousava intacta por sobre a pequena mesinha de estudos, já trazendo consigo alguns amassados de seu percurso.

No entanto, lá estava ela... Branca, livre, aguardando o encontro do acaso, em que eu, inebriado, sulcaria inumeráveis linhas, personagens, histórias, com lápis, gizes, canetas multicoloridas, colagens, dando vazão a um inefável imaginário. Um margem ampliada e amalgamada, amalgamargem. Margem de criança, contra-margem, (i)margem.

Sempre tive comigo, portanto, um lugar muito especial reservado às folhas de papel em branco. Palimpsestos de tempos onde uma certa liberdade na experiência estética poderia tranquilamente alcançar papéis, muros, chão, calçadas, cascas de árvore, até que, evidente, a primeira bronca fosse dada e, assim, alguma margem reafirmada.

Afinal, onde já se viu? Muros não são como papéis e papéis, veja bem, por vezes podem ser intransponíveis documentos. E, não obstante todo um universo ainda a ser rabiscado-criado, à criança são ensinados ${ }^{1}$ e reafirmados seus signos de margem. Há que se refletir portanto sobre as formas de educação que

\footnotetext{
${ }^{1}$ Ensinar, do latim, "insignare", remete à ideia de "transferir um signo a", "aplicar um signo em", ou seja, uma ação daquele que domina determinados signos e os transmite àquele que não os possui.
} 
apostam torrencialmente na gramática no lugar da poesia, na caligrafia no lugar do desenho livre, no ditado no lugar da contação de histórias, fazendo com que, aquela exultante liberdade experimentada passe a ser ao longo dos anos apenas uma memória, vaga ainda que grata, "o tempo do desenho livre".

Não caberia, sobremaneira, esvaziar as funções lógicas atribuídas, por exemplo, ao conhecimento gramatical da língua, bem como ao desenvolvimento da letra cursiva, e assim por diante - instrumentos estes que subsidiam alguma parcela considerável do processo de aprendizado e que inclusive ensejam, de algum modo, um quinhão de autonomia. No entanto, fundamentalmente cabe refletir a propósito de como os processos de produção de conhecimento seguem - sobretudo desde o século XVIII - apartando o ser, envolto em suas margens, das experiências estéticas que o rodeiam.

Deste modo, empreender uma pesquisa, escrever uma dissertação e, posteriormente, uma tese de doutorado, trata-se de um processo contínuo de construção/reafirmação de certas "margens". A margem do livro, em seu formato códice, permeia toda a atividade intelectual (desde sua fundamentação, letrada até a escrita) e assim, tanto nos habituamos a ela, que nem mais nos questionamos sobre seus propósitos e (des)caminhos. A margem da folha, do papel, limitando a matriz verbal (seja na lógica ocidental ou seu imediato inverso), pouco afeita à outras potencialidades de experiência estética, reina uníssona dentro de uma pretensa (des)ordem intelectual. (Des)Ordem esta uma expressão da reticularidade do pensamento, onde os infinitos fluxos, em meio aos processos cognitivos (que executam milhares de operações a cada segundo) comandam sua nau em meio a um oceano de desenhos livres.

Empreender uma pesquisa é, assim, portanto, também um reencontro com a oportunidade de livremente desenhar, a despeito da margem que tão logo se anuncia nas escolhas dos caminho que paulatinamente nos guiarão a partir de metodologias, técnicas, hipóteses, teorias, autores e afins.

É estabelecer e organizar interligações, concatenar referenciais, avançar em um caminho sempre turvo de descobertas, onde, ao fim, vislumbraremos uma ima(r)gem síntese deste caudaloso processo. Tessituras em jogo, texturas em reticularidade. 


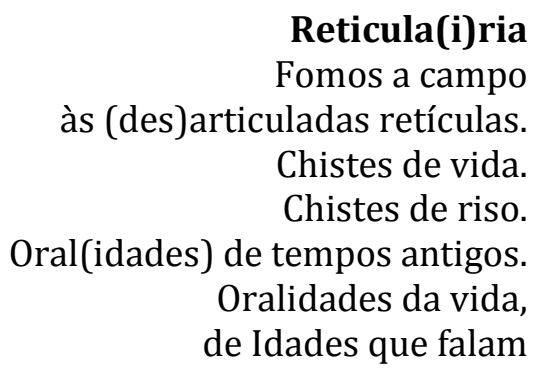

Nos percursos empreendidos nesta pesquisa, amiúde apresentam-se disjunções somente resolutas (ou quiçá, traduzíveis) a partir da marginalidade poética, chispas onde a fuga do hermético texto acadêmico encontrará algum repouso. Inadvertidamente estas se justapõe à medida que as margens do texto científico nos parecerem insuficientes.

O exercício, pois, da produção de conhecimento científico configura-se, tantas vezes, como um trabalho solitário. Do pesquisador e seu tema, seus objetos, sua relação protocolar com seu departamento, com as instituições de pesquisa, com "seu" texto. Embora atravessado por muitas pessoas e vozes, a configuração final de uma dissertação ou uma tese é, na grande maioria das vezes, um registro individual. Um perímetro circunscrito a uma dimensão isolada, bruta, de um fazer solitário, onde poucas vezes se tem a oportunidade de mensurar os desdobramentos, portanto os acionamentos coletivos, decorrentes dos fios propostos e tecidos. Tantas vezes, assim, são oportunos os questionamentos epistemológicos, não sem fundamentos, sobre a ética do retorno - daquilo que Boaventura Souza Santos chamaria de "dupla ruptura epistemológica" - dentro das humanidades, como no presente caso, em uma pesquisa filiada às Ciências da Comunicação.

Não é incomum, pois, sentirmo-nos incomodados, por exemplo, com a lógica dos congressos acadêmicos, onde as mesas por vezes parecem-se mais com palcos solipsistas, como um teatro de vaidades onde, em meio à toada dos monólogos, não raro é observar os outros colegas de congresso e das mesas 
distraindo-se em seus dispositivos móveis, enquanto aguardam o término de mais uma exposição.

Por vezes, porém, a vida nos reserva surpresas memoráveis, até mesmo advindas em alguma medida da camada fria de gelo que recobre nossas perspectivas e desenlaces acadêmicos.

O testemunho no presente percurso de pesquisa se dá na direção dos diálogos estabelecidos com algumas comunidades (sobretudo karajá e xavante), bem como com outros pesquisadores, realizadores e demais interessados na chamada "causa indígena".

Diálogo este sempre muito fértil, para além dos textos e contextos acadêmicos, onde a sua reverberação, portanto, é praticamente impossível quantificar. A devolutiva de um trabalho para as comunidades, seja este um audiovisual, uma hipermídia, ou até mesmo o exemplar de uma dissertação de mestrado - a despeito do inevitável baixo potencial estético do texto -, é sempre algo valoroso.

Neste processo, relembro a gratidão do amigo xavante Divino Tserewahú ao receber o texto "Produção Partilhada do Conhecimento: Uma experiência com as comunidades indígenas xavante e karajá" (LAZANEO, 2012), agradecendo pela memória que estava lá registrada e, dias depois, ligando para atestar de que o texto era respeitoso com sua cultura e, em suas palavras, estava tudo "direitinho". Relembro também a experiência inefável de entregar para o amigo karajá, Juanahú Iny e sua comunidade da aldeia Hawalo, 500 cópias do dvd do filme "Berahatxi-rbi Olodu Mahadu" (O povo que veio do fundo do rio), resultado de um processo de Produção Partilhada do Conhecimento.

Estas experiências transcendem a frieza dos textos, departamentos, assepsias acadêmicas circunstanciais e ampliam inevitavelmente nossos escopos e nossos lugares no mundo. Muito embora, por vezes, seja valoroso também testemunhar a possibilidade da criação de laços a partir um texto. 
Tonacci

Torna-te:

Tomado em ato.

Em um bang-bang contra o bang-bang.

Em um blá-blá-blá contra o blá-blá-blá.

No olho por olho contra o olho por olho.

No olhar pelo coração.

Conversas pelo mundo-mudo.

Olhar como ato de resistência.

Re-existência, como diria Daniel Munduruku. Re-existência diante da desordem do mundo.

Insistência pela estética, que reencontra a ética.

E vice-versa.

E re-existe.

Há de re-existir sempre, em nossos fotogramas da memória, em nossa celuloide do afeto, em nosso coração-índio, em nossa arte.

Cito também a valiosa lembrança de inesperadamente receber um email do grande realizador Andrea Tonacci, em julho de 2015, citando que havia lido o texto "Cinema Indígenas e Trânsitos da Representação", de minha autoria junto ao professor Sérgio Bairon. Tonacci havia gostado do texto, que por sinal analisava brevemente seu filme Serras da Desordem, de 2006, e conseguido meu contato junto aos editores da revista.

Ele pedia humildemente auxílio na curadoria de uma mostra de Cinema Indígena que começava a organizar no contexto do "19ำ Forumdoc - Festival do Filme documentário e etnográfico de Belo Horizonte" 2. Sua perspectiva era absolutamente interessante. Com apoio dos realizadores do festival e de patrocinadores, propunha organizar sessões de cinemas indígenas com a presença de realizadores indígenas brasileiros, bem como das três américas.

0 recorte curatorial propunha pensar um perfil histórico da representação indígena no cinema, exibindo e discutindo desde marcos como "In the land of the head hunters", de 1914, do americano Edward Curts, a partir da perspectiva etnográfica não-indígena, até filmes como, por exemplo, "Karioka" (2014), de Takumã Kuikuro, um ensaio antropológico sobre o Rio de Janeiro a partir do olhar de um kuikuro do Xingú. 0 artigo que proporcionou o diálogo

\footnotetext{
${ }^{2} 0$ 19o Forumdoc aconteceu de 19 a 29 de Novembro de 2015 em Belo Horizonte. A Mostra "Olhar: Um Ato de Resistência", ocorreu paralelamente à programação.
} 
atuava nessa direção, estabelecendo um recorte analítico de filmes sob o viés dos "trânsitos de representação", entre a heterorrepresentação e a autorrepresentação polifônica.

Os encontros e trocas com Tonacci foram demasiadamente férteis. Do meu lado, felicitava-me muito a ideia de contribuir com um realizador por quem nutro tanta admiração, além da rara possibilidade de participar de um encontro notável, com distinta diversidade e um recorte raro que privilegiava, sobretudo, uma tomada de direção por parte dos realizadores indígenas, ao contrário de uma certa exposição "festiva", a qual os festivais e seus públicos estão normalmente habituados. Esta "tomada de direção" propunha o protagonismo aos indígenas realizadores, tanto ao exibirem seus filmes, bem como ao conduzirem os debates posteriores.

Passado este encontro, continuei a estabelecer um diálogo frequente com Tonacci. Em janeiro de 2016 fiz a ele uma visita, junto ao meu amigo realizador Juanahú Iny e minha pequena filha Ceci. Nesta ocasião, Juanahú viera a São Paulo para trabalharmos em novos filmes para os karajá. Tonacci como me expunha, vinha trabalhando em um novo roteiro cuja narrativa se dava, assim como em alguns de seus filmes, em contexto indígena. Deste modo, sempre que podia ampliava o diálogo com os realizadores indígenas também a fim de aprofundar sua pesquisa, de forma que estas visitas lhe eram bastante gratas. Com o passar do tempo, ele confessara-me de que sua ideia era de que um realizador indígena dirigisse este roteiro em desenvolvimento e que pensava, carinhosamente, como o amigo Divino Tserewahú sendo alguém bastante qualificado para tanto. 


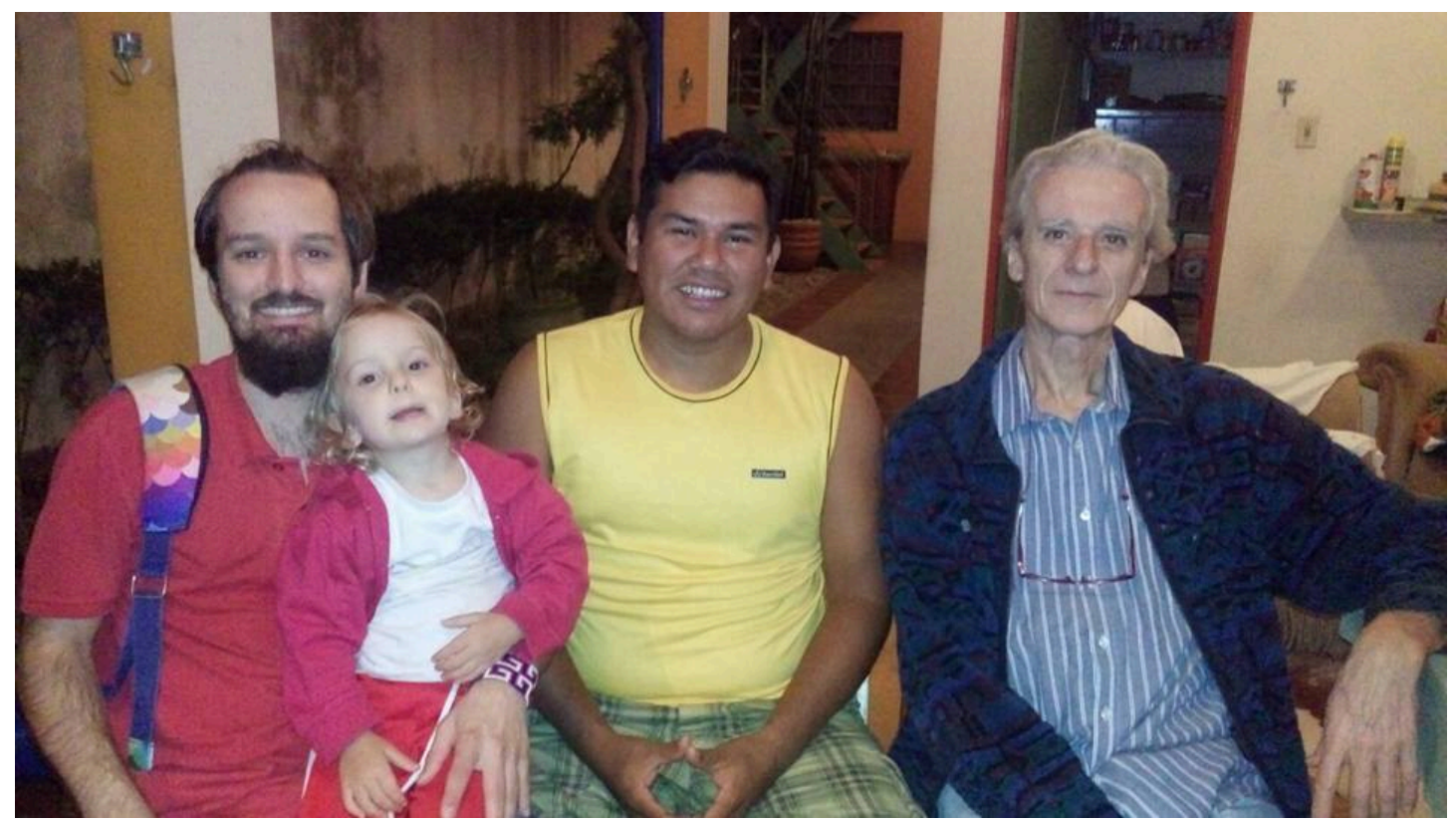

fig 1. Da esquerda para direita Caio Lazaneo, Cecília Morello Lazaneo, Juanahú Iny e Andrea Tonacci. (foto: Yanet Aguilera)

Infelizmente, porém, nos últimos meses Tonacci vinha enfrentando uma doença que de forma muito voraz foi lhe vencendo. Ainda assim, quando o visitei pela última vez, no final de novembro de 2016, a despeito de sua dor, ele ainda encontrava-se sereno e falava sobre o que esperava para este seu último projeto. Tristemente, no dia 16 de dezembro de 2016, Tonacci veio a falecer.

Nos deixando assim um legado imenso, um aprendizado constante, uma singela demonstração da reunião possível entre a ética e a estética substanciadas principalmente talvez naquele que seja seu grande trabalho, o grandioso "Serras da Desordem". Mas também em uma visão de mundo extremamente generosa, solidária, sempre em busca das partilhas possíveis. Na ocasião de sua morte escrevi estas palavras:

"Grande Mestre, querido Tonacci,

Eu deveria começar agradecendo-te por ter feito o maior de todos os filmes brasileiros, o eterno "Serras da Desordem". E assim o faço, com lágrimas nos olhos: Obrigado mestre! Desde que o conheci e também a teus outros filmes, sempre me peguei pensando... Como o cara que fez Bang-bang pode também ter feito Serras da Desordem? Ambos são de uma incrível inventividade, de uma sensibilidade exultante para seu tempo. Seria, pois, necessário mais do que só um gênio para fazê-los, no mínimo, evidentemente, dois. Não sei bem o que ou como me expressar nessa hora. Há três semanas conversávamos sobre os rumos 
que você pensava para teu último roteiro em processo e sobre a possibilidade da visita do Divino para auxiliá-lo (que chega agora, neste domingo, em casa). Perder pessoas assim como você é o atestado da grande desonestidade da vida, que tem como seu pecado maior o controle desatinado do tempo. Mas talvez os xapiris expliquem (ou sintam!), afinal os grandes espíritos devem habitar também os outros horizontes, as outras possibilidades, as outras sensibilidades. Todos os índios tem algo a celebrar pelo que você fez (e todo o MUNDO o tem!) como você sempre, generosamente, agradeceu aos índios pelos modos de vida que tanto lhes ensinaram -, certamente haverá sempre em algum lugar, algum ritual, que de forma festiva celebrará tua existência. Me lembro que certa vez (acredito que no forumdoc no ano passado) você disse algo como: “- É pela crueldade que me oprime que me vejo em fraternidade com o outro". É isso, portanto: um cinema fraterno, como o faz também teu irmão Luiz Rosemberg. Você é assim, um anjo torto, um Carapirú do cinema, um tanto xamã, eterno provocador de gigantesca e admirável sensibilidade. Mas... e que Cinema! Estupendo Cinema! Forte, sensível, reflexivo, humano, para sempre! Que saudade infinita, que dor recorrente será pensar na não existência de um novo filme do Tonacci (em um novo "Jamais visto")... o Cinema é eterno, você portanto vive e viverá, sempre! Obrigado Mestre!"

É certo que as páginas em branco que povoam nossa imaginação na infância e nos enchem de uma esperança criativa, urgente, haverão de, em algum momento, indefinidamente, assim permanecer. Assim como o ideograma "Mú" na lápide do grande cineasta japonês Yasujiro Ozu que representa o nada. 0 vazio. Somos sempre uma nova página em branco na incapacidade de que continuemos, nós mesmos, a preenchê-las. É, pois, assim que ficaremos. Na incompletude inexorável de nossa obra, nossa testamento para o mundo é sempre um devir, uma nova escrita no momento em que nos leem e, para além dos textos, no momento em que nos lembram, como o fazem os povos africanos quando enterram seus griôs anciãos embaixo dos baobás para que suas histórias continuem a fertilizar suas gentes. Grandes lideranças estas que, quando se vão, como diria Ailton Krenak, é como se junto fosse uma biblioteca É, portanto, à 
Andrea Tonacci e toda sua generosidade, da qual seremos sempre admiradores e signatários, a quem dedicamos em especial o presente processo.

Em branco

Como uma infância, eterna... Fugaz, porém. E (rare)feita de nuvem. Afeto de nuvem. Os pensamentos (naus e nus) vem e vão 0 corpo dos livros registram, o corpo dos livres sabem, como as sementes do devir. 


\section{Introdução ou Princípios da Partilha}

Poderíamos elucubrar que esta pesquisa começou pelo idos de 2008, quando eu havia recentemente me graduado e mudado para São Paulo, com um objetivo ainda não muito claro de elaborar uma pesquisa de mestrado. Logo nas primeiras investigações, adaptando-me ainda à vida na nova cidade, deparei-me com o texto "Os movimentos da estética: O cinema de Dziga Vertov como reflexão à Hipermídia" (2008), de autoria do prof. Sérgio Bairon, publicado na "RUA", Revista Universitária do Audiovisual da Universidade Federal de São Carlos.

A leitura do mesmo provocou-me agudamente, já que vinha dedicandome a entender desde meados do curso de graduação e ainda residindo em Piracicaba, interlocuções possíveis entre o cinema vertoviniano e as novas medias (tendo dedicado uma monografia para o tema). A clareza com que o texto e o autor atravessavam questões complexas e decifravam aspectos que tanto me encantavam na montagem de Vertov, despertaram-me de imediato uma vontade de interlocução.

Pois bem, assim de maneira despretensiosa, passei a corresponder-me com o prof. Sérgio Bairon, recém-chegado à Universidade de São Paulo, e a frequentar suas disciplinas no âmbito da pós-graduação em Ciências da Comunicação, na Escola de Comunicações e Artes da mesma universidade.

A princípio cursei (enquanto ouvinte) sua disciplina “Teorias da Produção do Conhecimento em Hipermídia" e posteriormente "Teorias da Produção Partilhada do Conhecimento". Ambas possuíam como eixo epistêmico a dimensão da produção do conhecimento a partir da Hipermídia onde, em linhas gerais, enquanto uma era focada em uma reflexão epistemológica, sobre a própria atividade científica e suas formas de produção de conhecimento (uma reflexão sobre a desvalorização da experiência estética na tradição científica), a segunda apresentava teorias, iniciativas e metodologias de pesquisas partilhadas com comunidades, em uma proposta de construção de conhecimento heterárquico e dialógico, isto é de forma conjunta com estas comunidades e seus interlocutores, utilizando para tanto recursos audiovisuais, hipermídiaticos, 
como valorização da experiência estética e dos conceitos inaugurados por estes encontros, sobre os quais, nota-se, os textos não surtiriam muito efeito.

Seguramente estas aulas jogaram-me ao encontro de uma floresta densa de incertezas, questionamentos, vontades, que, enfim, levaram-me a empreender uma pesquisa de mestrado. Neste percurso, tive a oportunidade de conhecer amigos que, como diria Marco Antonio Gonçalves (2008, p.21), a propósito da perspectiva de Jean Rouch, "o outro é simplesmente outro, não é objeto de estudo, é sujeito, e, antes de tudo, um amigo potencial". A começar pelo prof. Sérgio Bairon, quem desde sempre desfez qualquer possível e pretensa imagem do intelectual enquanto um sujeito instransponível, de um saber burocrático, distanciado e cerceador. Muito pelo contrário, desde sempre mostrou-se muito humano e próximo, amiúde generoso e tranquilizador, como são os bons griôs que sabem que o aprendizado está mais na escuta, na observação calma e harmoniosa das coisas e do mundo. Assim, transpomos rapidamente a linha divisória entre orientando e orientador, e tornamo-nos amigos.

Trago comigo a reflexão de que o que me fez fundamentalmente insistir (ou re-existir) em uma angustiante empreitada acadêmica, foi a oportunidade de ter encontrado o prof. Sérgio Bairon, ao acaso, neste percurso. Não naturalmente pela afinidade temática e conceitual e pela sua admirável trajetória acadêmica mas, sobretudo, por tudo o que está alhures deste perímetro. Sempre olhei com descrença para a figura do catedrático soberano, impassível diante de seus entornos e seguro em suas determinações de um saber individualista e distanciado. 0 prof. Bairon oportunava-me conhecer exatamente o oposto disso, a partir de uma epistemologia generosa, de valorização dos saberes Outros, de formas de vida que estão além dos currículos, dos congressos, dos conchavos sectários, da bajulação egocêntrica, enfim, de tudo aquilo que definitivamente não me interessaria vivenciar.

Pois a partir deste encontro, reticularmente ampliavam-se os caminhos. Conheci a profa. Aivone Carvalho, quem eu distantemente admirava por seu importantíssimo trabalho junto aos bororo e aos xavante em sua proposição de um Museu Vivo nas aldeias, de sua relação extremamente carinhos com a cultura material destes povos e com sua capacidade de ressignificação. Lembro-me sempre de sua fala quando, em 2011, eu saía de sua casa junto com o amigo 
Jonathas Beck para, pela primeira vez, darmos uma oficina de cinema na aldeia xavante Sangradouro. Ela, com um olhar terno e curioso perguntou-me:

- Tem certeza de você vai? Veja bem, uma vez que você for, não terá mais como voltar!

Passados quase seis anos deste episódio, recordo jocosamente o quanto sua assertiva era verdadeira. De fato, uma vez inserido no diálogo com os povos indígenas, em especial os xavante, bororo e karajá, posso dizer que nunca mais pude "voltar" a compreender o mundo como anteriormente a este encontro. Conheci Divino Tserewahú, Paulinho Kadojeba e Juanahú Iny e suas comunidades, com quem pude conviver em várias oportunidades e produzir filmes juntos. Vivenciamos experiências nas aldeias e na universidade, de forma partilhada buscando alicerçar nossas tantas proposições.

Hoje consigo reconhecer que o que mais me motivou a este encontro, tenha sido propriamente descobrir-me em uma alteridade "recoberta", anuviada. A admiração à distância que tinha com "o índio" (aqui tratado genericamente, como um arquétipo mítico infantil), até onde a memória consegue alcançar, vinha desde os tempos de criança e permaneceu talvez pela força de uma insondável filogênese. Em minha ascendência possuo origens europeias, mais especificamente italiana (avô materno por parte de mãe) e croata (avô e avó por parte de pai), no entanto, pelo lado maternal, minha avó propriamente era onde o fio da "história" se rompia, isto é, onde o registro oficial havia apagado suas marcas, suas gentes anteriores que, naturalmente especulamos, teriam origens indígenas. Uma marca atroz de nosso processo colonial, que cria heranças genéticas renegadas, violências compreendidas na expressão aquele que "foi pego no laço".

Pois meus bisavós ou tataravós, por parte de minha vozinha Niquinha, talvez assim o tenham sido. Talvez "pegos no laço", talvez expropriados, talvez perseguidos, talvez tenham tido seus modos de vida e identidades desafiados e renegados, obrigados a uma conversão vital. É esta, talvez, a ancestralidade que me conecta a um modo de vida índio. Embora claramente eu não possa viver deste modo, e embora o processo histórico tenha apagado suas marcas, sem dúvida a alteridade me propõe admirá-lo e respeitá-lo, a estar em sintonia com o 
"povo da borda"3. Sem uma perspectiva iluminista, romântica, mas desafiadora em sua diversidade.

Pois voltando as premonições, a profa. Aivone estava certa, visto que este diálogo nunca mais cessou. É fato que por vezes esfria-se, com a distância e com os descaminhos, com as urgências da vida, com o tempo que corre acelerado quanto mais pensamos sobre ele. Mas todo reencontro é sadio e festivo, afinal, mais do que pesquisa, é afeto. É transformador não só no âmbito epistemológico, mesmo que possamos com segurança defender que as atividades de Produção Partilhada têm sido, sim, efetivas em suas proposições de conhecimento, mas é também transformador porque nos vemos assim, partilhando nossos saberes, valorizando-os, permutando-os, sem sobrepô-los, nem solapá-los.

No ínterim deste processo ritual, quando eu terminava o mestrado e pensava em resguardar algum tempo para amadurecer uma nova pesquisa, tive uma conversa com o prof. Bairon que novamente me desestruturou, jogando-me mais uma vez para a liminaridade, recomendando que eu iniciasse tão logo possível esta pesquisa (assim, evidentemente, que fosse admitido nos exames do doutorado).

Hoje, com alguma distância, compreendo que este incentivo é semelhante, novamente, no saber dos mestre griôs, àquele puxão de orelha que os mais velhos dão em seus aprendizes. Afinal, é necessário sempre adentrarmos a um novo processo para que a espiral possa continuar. Neste entretempo, entre ser admitido e iniciar um novo processo de pesquisa, iniciava-se também a mais importante contribuição de minha vida até então. Pois, tão logo no primeiro ano de pesquisa, mais precisamente em seu quarto mês, nascia minha pequena Cecília.

\footnotetext{
3 Viveiros de Castro, nos posfácio do livro "A Sociedade contra o Estado" de Pierre Clastres, reflete: "Bem, talvez Pierre Clastres não fosse especialmente tolerante. Mas ele pertencia sem dúvida ao povo da borda, em mais de um sentido. Pois o caso é que todos nós precisamos em algum momento, na verdade, a cada momento, escolher entre "tornar-se índio"- habitar a margem e viver nas bordas (não é preciso passar a dormir debaixo da ponte; estamos falando de outra coisa) - ou permanecer no centro fortificado, confortavelmente identificado ao colonizador. Uma questão de, como direi?, "gosto". (in CLASTRES, 2011, 326-327).
} 
O desafio da paternidade conciliado ao desafio do doutorado, resultou, como justaposição, na palavra saudade, um ideograma que, talvez, nem mesmo os chineses tenham. Em uma fase na qual o processo de transformação de uma criança é absolutamente fugaz, tenho saudades dos momentos em que tive de me ausentar, por vezes por mais de um mês. Lacunas estas que hão de ser preenchidas e apaziguadas e que eu hei de recompensá-la narrando as histórias que aprendi.

Voltemos porém aos caminhos desta tese. Os princípios de partilha são estes que nos ligam a esta rede heterárquica, que há mais de uma década vêm trilhando os princípios epistemológicos do que temos denominado "Produção Partilhada do Conhecimento". O registro e reflexões deste processo não são advindos portanto apenas de um percurso de conhecimento individual, mas, senão, a uma rede de pesquisadores e interlocutores tantos das comunidades, quanto da Universidade de São Paulo que, juntos, temos trabalhado na criação de produtos partilhados.

Neste sentido, na interlocução com a Escola de Comunicações e Artes, e também tendo em vista minha formação, os processos de Produção Partilhada inevitavelmente perpassam o audiovisual. Em um primeiro momento, porque entendemos que as matrizes imagéticas e sonoras resultam em um processo efetivo de criação pertinente aos princípios das comunidades de tradição oral (onde há uma ampla valorização da experiência estética), como neste caso, uma aldeia indígena. Assim, a Antropologia Visual como regionalidade científica, há tempos vêm demonstrando a possibilidade de produção de conhecimento a partir do filme, algo que ensejou Bairon e Ribeiro (2007) a pensar também na interlocução entre a Antropologia Visual e a Hipermídia. Em um segundo momento, porque tanto os interlocutores como os pesquisadores demonstram afinidade e vontade de produzir e refletir a partir do audiovisual. Os filmes têm um impacto importante nestas comunidades, onde um texto, sobretudo científico, etnográfico, dificilmente teria.

Assim, o filme constitui um produto singular enquanto expressão de um processo de Produção Partilhada. É neste cerne portanto que concentraram-se nossas investigações. 
O primeiro capítulo "Reticularidade Fílmica”, propõe uma reflexão acerca do filme inserido em uma lógica hipermidiática. Para tanto, recorremos à teorias das novas medias, bem como uma reflexão sobre o cinema e o "fílmico", e propomos pensar a propósito de como a criação de ambiências, nas quais os filmes possuam a possibilidade interativa, poderá colaborar com os processos de Produção Partilhada. A reticularidade fílmica aqui, não corrobora com uma instância técnica de forma fortuita, senão com uma tentativa teóricometodológica de pensa-la inserida em processos, os quais, também alicerçam o cotidiano das comunidades de tradição oral. Onde a interatividade, a autoria do interator, a aleatoriedade como um jogo substanciem este diálogo na experiência estética.

O segundo capítulo trata-se de uma análise de duas propostas de reticularidades fílmicas. A primeira um documentário 360 canadense, “Out my Window", que contou com uma generosa produção da National Film Board, com dezenas de profissionais envolvidos e, logrou êxito, portanto, na criação de uma ambiência pertinente ao conceito que transversalmente perpassa o filme e, o qual, correlacionamos também a realizadores anteriores às novas medias, como Eisenstein e Vertov. O segundo é uma série de vídeos na plataforma youtube de manifestações do guarani-mbya de São Paulo, de autoria da CGY - Comissão Guarani Yvyrupá, ao que chamamos de uma espécie de "ocupação digitalreticular". Um dos eixos possíveis de início é a partir do filme "Rodovia Rojoko Por que ocupamos a Bandeirantes". A análise das duas propostas, estão fundamentadas nos princípios teóricos discutidos no capítulo anterior.

O terceiro capítulo propõe caminhar na construção das bases na Produção Partilhada do Conhecimento, e pensa-la na interlocução com outros princípios teórico-metodológicos, como a Antropologia Partilhada, a Pedagogia Griô e a Pesquisa Ação. Refletimos a propósito dos nós que cruzam os processos de Produção Partilhada e que, invariavelmente, devem envolver o trabalho de campo com comunidades e a universidade em uma redefinição epistemológica. Um percurso onde a ruptura epistemológica não apenas aparte a cientificidade do senso comum e assim permaneça, mas como compreende Boaventura Sousa Santos (2002), que uma dupla ruptura possibilite o retorno deste saber produzido ao "banco de dados" (para ficarmos em um termo caro à 
reticularidade e às novas medias) que a originou, isto é, ao próprio senso comum.

Por fim, o quarto e último capítulo, consiste em uma "etnografia" da Produção Partilhada empreendida junto à Juanahú Iny e sua comunidade Hawalo durante o mês de janeiro de 2015. Chamamos a esta de "Diários de Partilha". Compreendemos aqui que este trabalho é a síntese do que procuramos empreender ao longo desta pesquisa, isto é, o acolhimento por uma comunidade, o desenvolvimento de um trabalho de campo em conjunto com vistas à solução de questões inerentes àquela comunidade e, por fim, a devolutiva deste processo na forma de um produto que seja pertinente ao universo de sentido desta comunidade. Chamamos a estes registros, dos "Diários de Partilha", de etnografia tomando, entretanto, o devido cuidado, para não o inscrevermos à tradição antropológica que dedicou sua etnografia a propósito propriamente da sociedade Iny, seus rituais, sua cosmovisão, etc, e sobre os quais há uma bibliografia relevante. Consideramos, portanto, estes diários como uma etnografia da comunicação, isto é uma descrição de um trabalho de campo de Produção Partilhada, no qual podemos portanto considerar, por exemplo, o interlocutor desta comunidade, no caso Juanahú Iny, como seu principal etnógrafo (e antropólogo visual) e que, assim, os resultados de sua pesquisa estarão materializados em nossos filmes.

Ao longo do texto, optamos por manter as citações em língua inglesa, espanhola e francesa no idioma original, oferecendo nossa tradução nas notas de rodapé. Assim optamos por tratarem-se de textos ou ainda não traduzidos para o português ou consultados no próprio idioma das referidas citações.

Por fim, cabe ressaltar que os principais objetivos deste atual percurso de pesquisa não foram ainda plenamente atingidos. Durante o mês de janeiro de 2016, Juanahú Iny veio à São Paulo a fim de trabalharmos na edição de mais de 100 horas de material captado no ano seguinte. Este trabalho tem sido realizado por uma equipe pequena o suficiente para que as dificuldades aumentem substancialmente. 0 processo de montagem tem sido realizado por mim e por Juanahú. Das 100 horas de material, entre 6 e 8 horas deverão compor o banco de dados fílmico principal, o qual está em processo de tradução para o 
português. Juanahú embora fale fluentemente as duas línguas, não tem tanta facilidade no processo de tradução e depende, portanto, da ajuda de outros iny que detém um domínio técnico maior da tradução. Fora estas questões, ele trabalha regularmente como agente de saúde da Funasa e, nesta ocupação, constantemente viaja a trabalho, o que faz com que sejam relativamente raros os períodos em que passa um tempo maior na aldeia, nos quais pode se dedicar ao processo de tradução.

Entretanto, assim como o processo da pesquisa de mestrado que resultou no filme "Berahatxi-rbi Olodu Mahadu" (O Povo que veio do fundo do rio), e que levou mais tempo para ser concluído do que os dois anos disponíveis para a pesquisa, tínhamos desde sempre a percepção de que os quatro anos de uma pesquisa de doutorado seriam insuficientes para concluir os objetivos fílmicoreticulares que nos propomos. Assim, o texto que transcorre pelas páginas seguintes configura-se uma reflexão e um registro até o ponto onde conseguimos chegar mas que, inevitavelmente, o término do prazo para a conclusão da presente pesquisa não inviabilizará a continuidade da Produção Partilhada. Awire, seguimos!

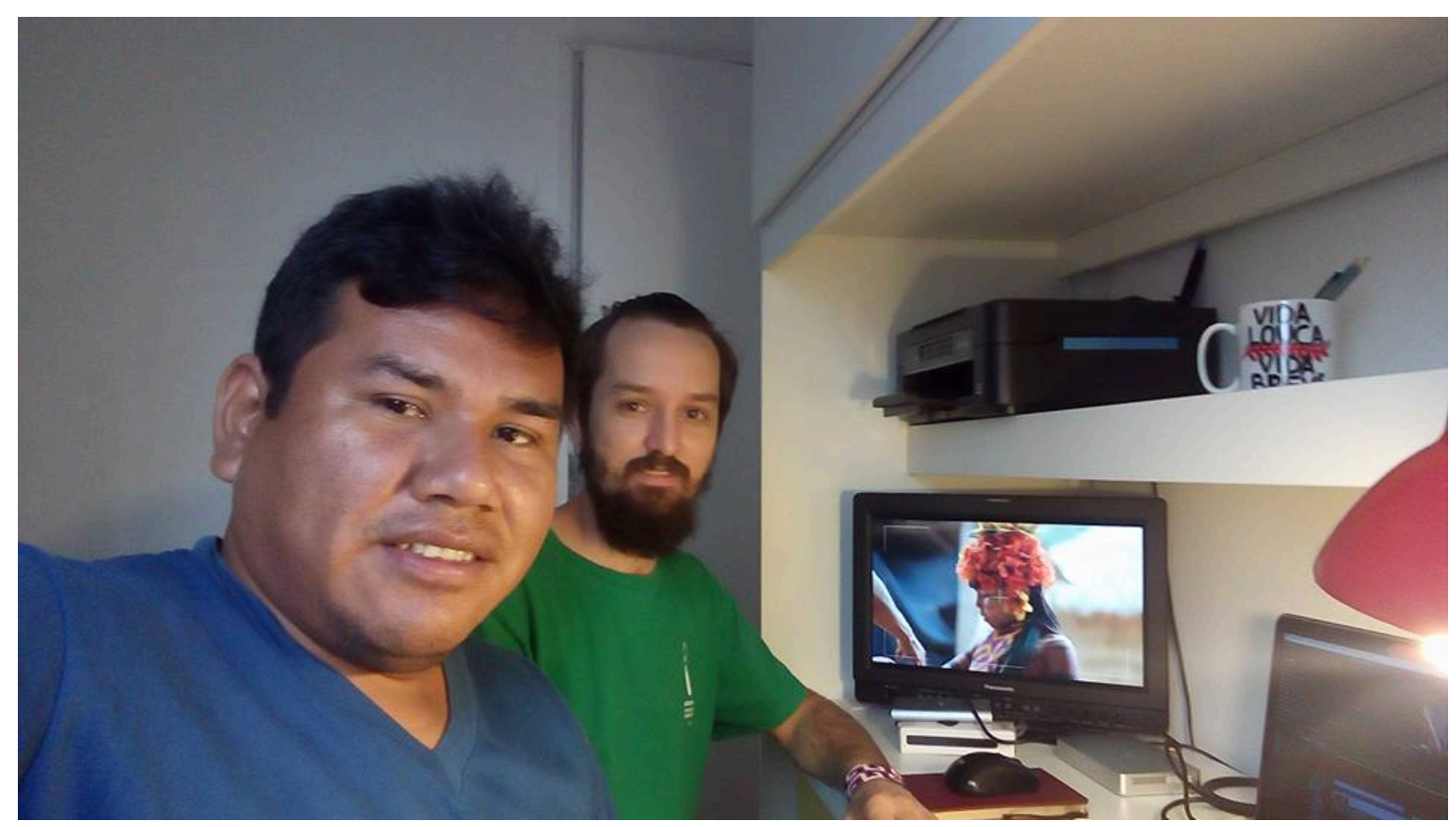

fig. 2. Juanahú Iny e Caio Lazaneo trabalham na edição dos filmes Iny. Janeiro de 2016. (Foto: Juanahú Iny). 


\title{
CAPÍTULO I
}

\section{RETICULARIDADE FÍLMICA}

\author{
ciência torta \\ Ante a retílinea \\ vigilância da epistemologia, \\ não seria desejável \\ a tortuosa \\ mestiçagem \\ da epistemolo(r)gia?
}

Neste capítulo propomos fundamentar o que temos denominado "Reticularidade Fílmica" (BAIRON, LAZANEO, 2013) no âmbito de sua proposição teórica, com ênfase em suas possíveis relações com as Novas Medias (MANOVICH, 2001), o Documentário Digital Interativo (GAUDENZI, 2013), a noção de criação de banco de dados fílmicos em Vertov (BAIRON, 2008, MANOVICH, 2001) e a concepção de Cinematismo em Eisenstein (BORDWELL 2005, MANOVICH, 2001). 


\section{Termos de uso}

Poderíamos de algum modo afirmar que a proposta de uma estrutura fílmicoreticular de Produções Partilhadas - quando construída em interlocução com as próprias comunidades e sujeitos geradores dos bancos de dados, possibilitaria um questionamento à problemática característica que acompanha, sobremaneira, a dimensão tecnológica e sua socialização? Característica esta, qual seja, seu imediato fetiche, o seu esvaziamento horizontal de sentido (reforçado pelo consumo não reflexivo e não protagonizado)?

A este respeito, recordamo-nos da crônica, narrada algumas vezes por amigos karajá, que contam sobre um certo mercado de "encomenda de rituais". De acordo com alguns relatos, certas vezes a comunidade mobiliza-se para executar uma determinada festa e/ou ritual pois o mesmo fora encomendado por uma determinada rede de televisão estrangeira, a fim de veicular em sua grade um documentário televisivo abordando rituais indígenas no Brasil.

Como a própria história das "máquinas de cinema" bem como do desenvolvimento das tecnologias audiovisuais parece estar sempre a atestar, o registro das "atualidades" de um povo, das suas festas, costumes e tradições, a partir da interlocução de um narrador encarregado de traduzir aquela experiência exótica, materializada pelos seus registros e de sua equipe, muitas vezes esteve a serviço de uma premissa colonialista. Assim como Piaut (2000) observa nos liames da antropologia, etnografia e do cinema, que acompanhou a racionalidade positivista e, ao longo do século 20, moldou parte importante do repertório e do pensamento cinematográfico e televisivo.

Há, portanto, públicos dos mais variados, ávidos por consumir e produtores ávidos por produzir, por exemplo, imagens "exóticas" de rituais de índios brasileiros, com amplo apelo ao "ineditismo" das imagens, às "práticas desconhecidas" então reveladas, etc ${ }^{4}$. Ao considerarmos que boa parte desta tradição prescinde, no

\footnotetext{
${ }^{4}$ Como se poderia observar, dentre inúmeros outros casos, a "tensão dialógica" surgida na desrespeitosa série realizada sobre o ritual fúnebre bororo e veiculadas no programa "Fantástico" da Rede Globo de Televisão. E a resposta dos bororo, contida no filme "Boé Eru Kurireu" (A grande tradição bororo), às mesmas reportagens. Cf. SATO, Sérgio. A tensão
} 
documentário, por exemplo de formas mais próximas ao modo reflexivo (NICHOLS, 2012), onde as negociações entre os atores sociais e os realizadores é também um dos objetivos do filme, naturalmente procura-se, de outro modo, solapar do espectador a revelação de que o ritual em questão, por exemplo, poderia ter sido encomendado pela própria equipe de televisão.

A comunidade karajá, como é de se esperar, sub-repiticiamente torna positiva a ocasião em vários sentidos. 0 primeiro é propriamente econômico, uma vez que pela encomenda a televisão pagará um valor acordado. 0 segundo é que, a despeito da ausência de um fator gerador5, inerente à lógica interna do ritual, este "falso-ritual" acaba convertendo-se de igual modo em uma atividade festiva, uma espécie de ensaio celebratório onde, a despeito de estar "a serviço" do olhar estrangeiro, saberá subverter o afã deste pelo espetáculo, em benefício da própria comunidade, ou seja, o "ritual-fake" é também um ritual.

Desta pequena crônica decorre uma reflexão sucinta, embora oportuna. É provável que isto que já foi chamado de "fetiche do exótico", continue a exercer seu fascínio, por exemplo, também em ambientes fílmico-interativos, para além das possibilidades televisivas mais tradicionais. As chamadas novas medias e sua linguagem, não rompem em absoluto com as práticas comuns às medias anteriores, outrossim muitas vezes é possível observarmos, por exemplo, princípios da lógica de criação de banco de dados, em medias analógicas muito anteriores ao digital (MANOVICH, 2001).

Dentre um vasto horizonte de questões pertinentes, refletimos sobre quais são as possbilidades ensejadas pela reticularidade fílmica, no âmbito do audiovisual hipermidiático, que propiciariam pois um rompimento com o que chamamos de esvaziamento horizontal de sentido. Certos meios - ditos "tradicionais" (como o rádio e a televisão) - criados e gestados por povos indígenas, por exemplo, entre outras articulações, existem e co-habitam os espaços midiáticos, fluxos informativos e redes diversas há um tempo relevante. Outrossim, a presença indígena na web passa a ser cada vez maior, ou seja, o digital indigeniza-se ${ }^{6}$. Ambas possiblidades podem atuar no papel

Dialógica entre auto e heterorrepresentação no funeral Bororo na Terra Indígena de Meruri. 2009. Dissertação de Mestrado. Pontifícia Universidade Católica, São Paulo. 2009.

${ }^{5}$ Como por exemplo no ritual do Hetohoky, em que a iniciação de um (ou mais) novo(s) jyré (s) jovens que farão a passagem à vida adulta - é o principal motivo para a realização do ritual.

${ }^{6} \mathrm{~A}$ propósito de uma pesquisa sobre o habitar indígena brasileiro nas redes digitais, em especial a "Rede Povos da Floresta", Cf. PEREIRA, Eliete da Silva. O local digital das culturas: as interações entre culturas, medias digitais e territórios. 2013. Tese (Doutorado em Interfaces 
de uma comunicação heterárquica, na reticularidade da horizontalidade de sentidos. Há portanto nesta confluência um solo extremamente fértil. ${ }^{7}$

Assim, em âmbito digital, o que compete à Produção Partilhada não seria tão somente pensar e propor a construção das ambiências onde a reticularidade possa configurar-se enquanto um encontro inaugural do conceito, gerado na relação universidade e comunidade mas, de igual modo, propiciar a autonomia, a partir da consolidação de redes sólidas e abertas, a fim de compor este processo. Destarte, é essencial que os interlocutores de ambos os vetores sejam capacitados a continuar alimentando estas redes.

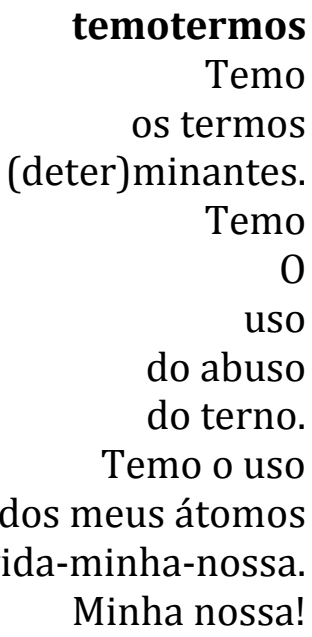

Sociais da Comunicação) - Escola de Comunicações e Artes, Universidad de São Paulo, São Paulo, 2013.

${ }^{7}$ Gaudenzi (2013) relata, por exemplo, a propósito do projeto televisivo do canal BBC2 Video Nation, onde grupos de pessoas foram selecionados e receberam câmeras de vídeo e treinamento específico. A partir disso, construíram registros de suas vidas cotidianas ao longo de um ano e, posteriormente também detinham direito de veto sobre o trabalho dos editores que recebiam os materiais audiovisuais, sem que nada fosse veiculado sem seu consentimento. Experiências como esta do canal inglês tem um importante lastro no cinema verité e seu princípio participativo. Cf. GAUDENZI, Sandra. The Living Documentary: from representing reality to co-creating reality in digital interactive documentary. Tese de Doutorado. University of London. 2013. 


\section{Pensar e criar}

A reticularidade, em ambiências digitais, vem sendo, há algum tempo, produto de ampla exploração mercadológica, como expresso em comerciais de refrigerante, dispositivos móveis, roupas, etc. Esta direção, subentende uma verticalização tecnológica inerente aos princípio dos softwares autorais, das programações em linguagem fechada, que engendrados em uma sociedade do espetáculo, apartam os indivíduos de seus processos de produção. Neste seara, interessa propiciar um consumo interativo, que, sobretudo no âmbito publicitário, propicie ao interator-consumidor uma experiência transmidiática com a marca. 0 interator-consumidor (ou pro-sumer) é convidado a contribuir, isto é "partilhar" conteúdo por ele criado, na medida em que esta ação coadune-se com os objetivos (mesmo que imiscuídos) da campanha8.

Embora muitas das plataformas contemporâneas, como é o caso do youtube, propiciem aos sujeitos uma gama de configurações que, com alguma liberdade, permitem alguma programação bastante básica, é fundamental nos questionarmos sobre seus propósitos e os desdobramentos de nossa ação nas mesmas.

Disto decorrem duas questões basilares: A primeira aponta para a problemática que envolve a relação entre pensamento e criação, entre a margem e a experiência estética: 0 que penso/crio quando crio/penso a partir do youtube, facebook e similares? À medida em que nós, enquanto navegadores, não desenvolvermos a oportunidade de criarmos nossas próprias plataformas e aplicativos e ficarmos à mercê da interação com softwares autorais, de algoritmos que determinam uma navegação mercadológica, prédefinidos, construídos para propósitos muitas vezes genéricos, a que tipo de experiência nos propomos? De fato experimentamos?

A segunda problemática surge no esteio da primeira. Conforme se complexificam os algoritmos que determinam como, com o que e com quem nos relacionamos e interagimos - com os quais concordamos nos indefectíveis "termos de uso" - mais apartados do processo conceitual nos encontramos. Mais somos rifados, "presetados",

8 O termo UGC (User Generated Content), ou seja, Conteúdo Gerado por Usuário, surgiu com a web 2.0 e a popularização da blogosfera, como um princípio de cultura participativa que pressupõe, na relação com os meios digitais, a passagem do usuário para o pro-sumer, isto é, um consumidor prospectivo que também envolve-se no desenvolvimento, no design, e em outras etapas criativas. 
transformados em produtos, ofertados em pequenos leilões das gigantes do Vale do Silício, que nos vendem em blocos aos anunciantes que miram seus públicos alvos, ávidos por cliques.

Ao "subirmos" nossos vídeos, com percepções, experiências estéticas, vivencias das comunidades de tradição oral, em concordância com os modelos de público alvo, direitos autorais, engajamento, ranqueamento, distribuição, reprodução, das empresas fabricantes e gestoras destas redes, não estaríamos (todos os agentes) de algum modo potencialmente folclorizando - transformando em produto - estas mesmas comunidades? Por outro lado, esta visibilidade potencializada não seria importante, para não dizer algumas vezes fundamental, para o reconhecimento e, por vezes, alguma forma de subsistência das mesmas?

Estas parecem-nos questões cruciais. Um fenômeno que assemelha-se à dinâmica demonstrada por Canclini (1983) no caso do artesanato de povos tradicionais mexicanos, em que as chamadas "culturas populares" passam a adequar-se às demandas mercadológicas dos processos de globalização, a fim de que seus produtos tenham maior penetração e aceitação comercial. Embate este, de certo modo, recorrente e nem sempre resoluto no contexto contemporâneo, inclusive em seus desdobramentos jurídicopolíticos por exemplo. Não são poucos os exemplos de marcas que estabelecem estratégias publicitárias, e fazem o uso de patrimônios culturais de determinados povos, como por exemplo grafismos de etnias xinguanas, para "enfeitar" - não haveria talvez outra palavra - seus produtos. Em um caso recente, uma famosa fabricante brasileira de sandálias, foi processada por associações indígenas, por estampar, em uma série de chinelos, grafismos de povos xinguanos, sem a autorização expressa dos mesmos. 0 mesmo estende-se à marcas de carro (quando desejam criar alguma associação ao aspecto "aventureiro" de seus veículos), grifes de roupas, etc.

Afinal, como refletiria Davi Kopenawa (2015), os povos indígenas estão sempre à mercê do "povo da mercadoria", sua sucinta definição para a sociedade do consumo. Outro paralelo possível: Quando uma empresa "visionária" adquire créditos de carbono - os REDD (Redução de Emissões por Desmatamento e Degradação florestal) -, junto à comunidades indígenas da Amazônia, por exemplo, a quem se está beneficiando?

Em uma direção poderíamos supor que a comunidade estaria sendo diretamente beneficiada, uma vez que o dinheiro proveniente dos créditos potencialmente poderia ser utilizado para auxiliar a infraestrutura das aldeias, na diminuição do êxodo em busca 
de trabalho nas cidades, etc. Por outro lado, este mercado, evidentemente inserido em um capitalismo sofisticado mais especificamente em sua faceta conhecida como "capitalismo do desastre" (SCHMIDLEHNER, 2013), compreende que, para tornar-se um produto atraente, os créditos deverão estar centrados e ofertados em regiões que ofereçam "risco", o que potencializaria seu valor de aquisição, ou seja, o investidor capitalista, consequentemente poluidor que busca "neutralizar" suas emissões, somente teria interesse em adquirir créditos de áreas com potencial destrutivo, o que alimenta a lógica perversa da especulação, do caráter nefasto da "adicionalidade de medo".

Além desta característica, as comunidades indígenas sujeitas aos contratos autoritários dos REDD, transfigurariam-se, nas palavras de Schmidlehner (p. 30) , em "espantalhos culturais", uma vez que, concordando com os termos das empresas que adquirem estes créditos, ficariam inviabilizadas de continuar com seus modos de vida tradicionais, que envolvem a pesca, a caça, o roçado, etc, pelo impacto consequente nestas áreas "preservadas". E, um terceiro fator (ainda muito questionado), estariam contratualmente reféns de empresas que nutrem especial interesse por patentes de plantas, princípios ativos naturais, e etc, originários das florestas tropicais.

Esta configuração do capitalismo que sorrateiramente camufla suas intenções, não cessa, no entanto, de aflorar as violentas marcas, herdeiras de um amplo processo colonialista. Não podemos deixar de lembrar que, de acordo com relatório "Em solo perigoso" (WITNESS, 2016), da ONG Global Witness, o Brasil lidera sucessivamente, desde 2011, o ranking 9 de assassinatos violentos no campo motivados por disputa de terra; Em sua maioria campesinos, ribeirinhos e indígenas. Estes, muitas vezes, envolvidos em movimentos sociais e organizações contrárias à projetos políticoeconômicos de construção de barragens, estradas, mineração, agropecuária, portos, grilagem, etc. O relatório chama ainda atenção ainda de que, em 2015, indígenas representavam $40 \%$ destas mortes no mundo.

Nos parece oportuno, portanto, refletir que o conflito posto entre os povos tradicionais, povos originários, povos da floresta frente às dinâmicas políticoeconômica-culturais, levadas a cabo por governos de todas as esferas, empresas e indústrias de todos os setores, podem e devem ser também enfrentados no que convencionamos compreender enquanto "mundo digital", propício este àquilo que

\footnotetext{
${ }^{9}$ Disponível em https://www.globalwitness.org/en/reports/terreno-peligroso/. Acesso em: 05/09/2016.
} 
Shohat e Stam (2006) chamariam de "media jiu-jitsu", ou o que chamamos aqui - em relação aos guarani-mbya - de mída xondaro, ou seja, ao poder de reverter forças contrárias a seu próprio favor; um locus onde estes mesmos povos, em contexto frequente de hibridização e em uma perspectiva não-hegemônica, criem estratégias de "reconversão" (CANCLINI, 2013).

Tupiniquim(ioterapia) No genoma, o gênesis Da gema, geme, nasce, nascente, (Pausa) Estirpa, tira, arranca a tripa Constrói a nação-barbárie.

Tupiniquimioterapeutas aos poucos retiram o que consideram tumores da indigênesis. Aos muitos, retiram os rumores dos tubérculos das terras.

Das terras que são gentes, gêneses. Retiram os tubérculos de ouro, pratas, minérios, matas, Matam e espalham mercúrio e bandeiras Bandeirantes da (tupini)quimioterapia, Carangueijos em caravelas e cruzadas, Sardinhas com espadas na mão, Prontas para a próxima sessão De medicina colonial. Papada a sardinha do papa, Contra tua tupiniquimioterapia asceta, Lança-se a seta do xamã, antropofágica, Do povo-terra frente ao povo-mercadoria. 


\title{
Cine-dormência
}

\author{
o sonho \\ conjuga \\ um dor meeting \\ na door mente, \\ porta mental de portmanteau, \\ do do(r)mínio da vazão.
}

Entre fluxos, nos pegamos a pensar sobre a dimensão onírica a envolver o espectador em meio a um filme em que, exausto, não consegue vencer suas pálpebras vacilantes e, permitindo-se principiar em seu sono, vê-se imerso aos muitos sentidos, outrora audiovisuais, agora já produtos do inconsciente - não obstante, também fartamente visual. Ora, assistir a um filme e acordar em meio a este mesmo filme, possibilitando com que as justaposições do sonho liguem-se às do novo trecho que se projeta, jamais será igual a assistir um filme sem dormir.

O filme que vemos entre as intermitências do sono é irreproduzível, é algo portanto mágico, aurático, único. Sem que façamos aqui nenhum juízo a propósito do grau de apreensão dos signos fílmicos, expressos sobretudo, comumente, em sua estrutura narrativa e sua linguagem, não obstante consideramos a cine-dormência também, por excelência, como um processo de montagem reticular, isto é, cinedormência como jogo, como mecanismo de acionamento do além-fílmico. Neste sentido o cinema já nasceria, por assim dizer, com alguma potencial reticularidade na cinedormência, no banco de dados que alimenta nosso sonho e, por conseguinte, interliga-se a uma possível estrutura fílmica.

A psicanálise ${ }^{10}$ bem como outras áreas do pensamento humano dedicaram especial atenção à dimensão onírica com a qual flerta o ritual cinematográfico. Estar imerso em uma sala escura, em um ambiente recolhido e silencioso, olhando para uma

\footnotetext{
${ }^{10}$ As correspondências entre o surgimento do cinema, no final do século 19, e da psicanálise são muitas. 0 ano de 1895, por exemplo, data da primeira exibição dos filmes dos irmãos Lumière, é o ano em que Sigmund Freud e Joseph Breuer lançam "Estudos sobre a histeria", que inaugura a teoria psicanalítica. Há uma diversidade de autores que baseam-se na teoria psicanalítica para o estudos do cinema. Metz (1980), por exemplo, utiliza elementos da análise psicanalítica (condensação e deslocamento, metáfora e metonímia), sobretudo de Freud e Lacan, e da semiótica para o embasamento da análise cinematográfica.
} 
tela grandiosa seria como, de algum modo, propiciar uma situação onírica (ou, em alguma instância, propensa para tal).

Walter Murch, salienta esta característica em seu livro, a propósito da montagem cinematográfica, "Num piscar de olhos" (2004), quando narra, em meio ao processo de montagem de um filme, que teria tido lido uma entrevista com John Huston, onde o diretor destacava exatamente este mesmo aspecto: 0 cinema funciona na medida em que apresenta-se como um processo semelhante ao sonhar, isto é como projeção, o filme enquanto sonho, para além da enfadonha vida "ordinária”. Esta percepção, em Murch, despertou também um "olhar" para a característica psico-fisiológica do piscar dos olhos nos atores; o que passou a considerar, em alguma medida, como algo que contribuiria substancialmente para a apreensão fílmica e, consequentemente, para o procedimento criativo da montagem.

Esta filiação entre o cinema e o sonho - o cinema em flerte com a matéria prima do inconsciente -, com q qual concordam por Huston e Murch, não no sentido híbrido no (na intermitência) da cine-dormência, mas em seu potencial simulacro do dispositivo fílmico, isto é, como um "sonhar de olhos abertos" (enquanto se assiste a um filme), enseja-nos refletir sobre o cinema nos interstícios do regime da linearidade narrativa bem como (no perder-se) da multilinearidade e multiplicidade hipermidiática. Como se dão os fluxos do desejo inconsciente ${ }^{11}$ que configuram a elaboração onírica quando tratamos das distintas formas?

Não obstante não tenhamos a premissa de encontrar respostas para este jogo, ou melhor, mais do que buscar respostas tenhamos a premissa de jogar (e portanto perguntar), há outra pergunta que nos rodea: Como se relacionam a tríade sujeito (espectador ou interator), o sonho e o fílmico, com a narrativa e com o banco de dados, considerando a "passividade" contemplativa pressuposta na linearidade frente à ação exteriorizada pressuposta na multilinearidade superlativa?

Alhures da questão do "cinema-sonho", Eisenstein, defenderia, por exemplo, o uso do monólogo interior como mais apropriado ao cinema, ou seja às questões

11 Zizek (2009, p. 215) lembra que a propósito da intepretação dos sonhos freudiana, "o verdadeiro núcleo do sonho não é o pensamento latente que é deslocado/traduzido na textura explícita do sonho, mas o desejo inconsciente que, por intermédio da distorção do pensamento latente, inscreve-se na textura explícita do sonho". 
coletivistas, até mesmo do que para a própria literatura (XAVIER, 1983, p.177) ${ }^{12}$, como reflete Deleuze

O monólogo interior vai além do sonho, que é individual demais, e constitui os segmentos ou os elos de um pensamento realmente coletivo. Desenvolve uma força de imaginação patética que chega aos confins do universo, um 'uso desregrado de representações sensoriais', uma música visual que cria massa, jorrar de creme, fontes de águas luminosas, fogos faiscantes, ziguezagues formando cifras, como na célebre sequência de $O$ velho e o novo. ${ }^{13}$ (1995, p.193)

\section{Cinespiral}

um espirro

como um lance

de dados.

o espirro é o acaso

do kino.

No princípio dos anos 90 do século XX, Jean Claude Carriére, notável roteirista cinematográfico, refletia a propósito de possíveis processos criativos que envolvem a aleatoriedade de escolha em um ambiente de polifonia fílmica:

E se estou uma noite em casa, assistindo a um filme na tevê (pois é nela que geralmente vemos os filmes ou os revemos pela segunda vez), e perco a paciência com o tipo de quietude de que me desacostumei, ou estou aborrecido com a intrusão inesperada de um comercial, rapidamente, com o controle remoto, mudo para outro canal. E, se acho um filme interessante, esqueço tudo sobre o primeiro; o novo filme me prende totalmente a atenção.

\footnotetext{
12 Eisenstein teria inclusive se encontrado e discutido sobre o monólogo interior com James Joyce em suas viagens por Estados Unidos e Europa em 1932 e 1933. Cf. EISENSTEIN, Sergei, apud XAVIER, Ismail (org.). A experiência do cinema. Ismail. A experiência do cinema: antologia. Rio de Janeiro: Graal: Embrafilme, 1983. Sobre Eisenstein e o monólogo interior Cf. o pensamento e o Cinema. in DELEUZE, Gilles. A imagem-tempo. Tradução Eloisa de Araujo Ribeiro. São Paulo: Brasiliense, 2005, pp. 189-198.

${ }^{13}$ Itálico do autor.
} 
Assim - como autor incidental, favorecido pelo acaso -, recrio, com uma só mão, o caos de imagens e sons que hoje em dia constituem a textura de tantas de nossas noites. 0 zapping se tornou uma forma objetiva de criação. Goste-se ou não disso, o aparelhinho preto de controle remoto é o mais recente instrumento individual de realização de filmes. Por isso, essa conquista individual que, em certos casos, já pode ser chamada de auto-expressão e que, algum dia, poderá ser chamada de arte, essa 'afirmação pessoal' que se realiza ao apertarmos o botão do controle remoto, quase sempre de modo inconsciente, é a última palavra em criação cinematográfica; o mais recente avatar de uma linguagem que nos era desconhecida cem anos atrás. (2006, p. 26-27)

No zapping, esta capacidade de imediata interferência fruitiva, ao que Carrière considerava a última palavra em "criação", ou enquanto "instrumento individual de realização" (a câmera propriamente também não o seria?), teríamos, portanto, uma dimensão fulcral de um processo de montagem reversa que, certo modo, conduzido pelo espectador, reivindicaria a partir de uma espiral fílmica, um acaso objetivo, obedecendo a uma justaposição mental, na qual, a vida doméstica converte-se, de alguma maneira, em live cinema, isto é, um cinema montado no instante, de acordo com a vontade de seu interator.

É certo que, em termos tecnológicos, muito se avançou desde quando Carrière descreveu sua percepção a propósito da liberdade experimentada com a mediação de um controle remoto. Hoje é possível, por exemplo, o uso de dispositivos que, acoplados aos ecrãs, são capazes de mapear o foco de atenção do espectador e sugerir (a partir de um algortimo imputado sobre o banco de dados), com base no deslocamento de seu olhar pelo quadro, um novo desdobramento para sua fruição fílmica. Uma espécie de controle remoto hibridizado à retina. Outrossim, tags, palavras chave, cookies rastreiam as navegações na web de forma sofisticada e sorrateira, e filtram nossos gostos, particularidades, e sugerem listas (e montagens) daquilo que consideram condizente às nossas subjetividades.

$\mathrm{Na}$ passagem da lógica do filme linear narrativo à multilinearidade do banco de dados, há outra característica fundamentalmente distintiva em relação à fruição de cada contexto. Na web, de modo geral, os filmes parecem explorar um tempo curto de duração, já não mais ofertando ao espectador - convertido em interator, ou em 
"navegador" (Chartier, 1998) ${ }^{14}$, em sua relação com as texturas eletrônicas - a ênfase em uma fruição prolongada, como na lógica de um longa-metragem em uma sala de cinema. Esta mesma dimensão, de um tempo reduzido, acompanha também a tendência dos serviços de streaming onde, ainda que se ofertem séries em que duração de cada episódio é semelhante aos filmes comerciais ou formatos padronizados pela televisão comercial, o espectador tem a possibilidade de interrompê-lo e, após um intervalo, retomá-lo em outro dispositivo, vivenciando uma "reprodutibilidade técnica" da narrativa.

O formato longa-metragem (feature film no inglês), por excelência, guarda ainda, sobretudo em línguas latinas, a ideia literal de uma metragem estendida (que passa a ser assim considerada a partir de algo em torno, a depender da convenção, de 1.500 metros de filme finalizado - quanto a um parâmetro analógico - ou a partir de 70 minutos de duração). Generosos quilômetros de linearidades pré-compostas. Já o zapping subversivo atua como uma tesoura nas mãos de um montador que, em uma ilha de edição analógica, corta o filme.

A partir desta possbilidade, como anunciava Carrière, já vilumbrava-se de forma ampliada para o comsumo doméstico (muito além do âmbito, por exemplo, de um filme interativo em um museu, restrito a um número pequeno de pessoas) a característica fragmentária da percepção do sujeito na fruição audiovisual, "do perder-se" exponencializado pelas novas medias e sua lógica de banco de dados, um fenômeno ao qual Lipovetsky e Leroy (2009) chamariam de "a tela global”, isto é, o ecrã onipresente, uma "ecranosfera", não mais um ecrã contemplativo (a ocupar o espaço central das salas das casas das pessoas), mas relacional, locativo, transitivo, em contiguidade, tangível, com plena possiblidade de interação.

0 artista hipermidiático britânico Peter Greenaway considera que o modelo que sustenta o modo de produção cinematográfico e sua linguagem, estaria há muito superado. Sua leitura permite supor que o cinema, talvez, nunca tenha sido devidamente

14 Para Chartier (1998, p. 187): “A revolução do nosso presente é, com toda certeza, mais que a de Gutenberg. Ela não modifica apenas a técnica de reprodução do texto, mas também as próprias estruturas e formas do suporte que o comunica a seus leitores. 0 livro impresso tem sido, até hoje, o herdeiro do manuscrito: quanto à organização em cadernos, à hierarquia dos formatos, do libro da banco ao libellus; quanto, também, aos subsídios à leitura: concordâncias, índices, sumários etc. Com o monitor, que vem substituir o códice, a mudança é mais radical, posto que são os modos de organização, de estruturação, de consulta do suporte do escrito que se acham modificados. Uma revolução desse porte necessita, portanto, outros termos de comparação." 
experimentado: "[...]A bem da verdade, hoje tendo a achar que o cinema nunca esteve vivo. Tudo o que nós vivemos até agora foram cento e tantos anos de texto ilustrado" (BARCINSKI, 2007). Em sua inquietude, pergunta: "Could is not travel on the road where Joyce, Eliot, Borges and Perec have already arrived?"15 Ao passo que ele mesmo permitese responder "the linear pursuit - one history at a time told chronologically - is the standard format of cinema" 16 .

A estas provocações, adicionaríamos mais perguntas: 0 que temos visto, em larga escala, nos últimos cento e poucos anos da tradição cinematográfica - sobretudo desde sua consolidação enquanto um modelo de negócio em escala industrial (após o período conhecido como Primeiro Cinema) -, de modo geral, não é algo senão um amplo e irrestrito uso do texto (ou da matriz escrita) a balizar a cinematografia (fundamentalmente em sua dimensão narrativa)? Não seria esta característica o que converteria, consequentemente, ao desenvolvimento da linguagem audiovisual um papel de ilustração, a partir desta metodologia amparada no texto?

Ao que Greenaway amiúde nos chama provocativamente atenção, como por exemplo na compreensão de que "[...] o cinema tem a curiosa desvantagem de ser, como eu disse, uma ilustração. Ilustração é uma palavra suja. Eu não quero ilustrar, eu quero criar. A linguagem do cinema é extraordinária, mas ela é desperdiçada no cinema". (BARCINSKI, 2007). Neste sentido, pois, far-se-ia necessário adentrarmos a uma "préhistória" do cinema, isto é, de sua redescoberta à margem da tradição escrita

A despeito de sua verve constantemente provocadora, o que traz uma corrente de desafetos, Greenaway tem contribuído com uma valiosa obra inerente ao que consideramos um cinema inserido na lógica dos bancos de dados (MANOVICH, 2001), uma implosão da univocidade de sentido sustentada unicamente na narrativa. A abrangência de suas realizações vai além do espaço circunscrito às salas de cinema, privilegiando também museus e locais voltados para a criação de instalações, o que Greenaway compreende como o "cinema além do cinema".

15 Tradução nossa: "Não poderíamos viajar pela estrada que Joyce, Eliot, Borges e Perec alcançaram?" (citado por Manovich 2001, p. 237).

16 Tradução nossa: "A perseguição pela linearidade - uma história no tempo contada cronologicamente - é o formato padrão do cinema". (citado por Manovich 2001, p. 237). 
A propósito do que Bairon e Torres (2009, p.12) refletem sobre o afastamento do barroco pelo iluminismo ${ }^{17}$, na perspectiva da incompletude que frontalmente desafiava a racionalidade discursiva emergente da época, compreendemos como possível, na contemporaneidade, estabelecer um paralelo com o cinema de Greenaway, em particular por sua lógica de criação na incompletude do banco de dados que desafia a convenção hegemônica da narrativa. Seu cinema não só busca referências no barroco histórico ${ }^{18}$, bem como alia sua poética à características que seriam próprias de um "neobarroco" (CALABRESE, 1987; CHIAMPI, 1998) da contemporaneidade.

Este "resgate" configura-se processo de seu próprio jogo, enquanto uma lógica também inerente à criação em novas medias. Ao tratar da forma, Greenaway dá vazão à sua herança plástica da estética barroca, sobretudo ao pensar a luz e as cores, onde “a expressão estética deste diretor constrói uma singularidade autoral, demonstrando sua opção por um cinema de referências, isto é, um certo tipo de obra de arte contemporânea marcada pelas citações da história da arte e recriada a partir de sua contextualização paródica" (GARCIA, p.74, 2000).

Sua filiação, como reiteradamente manifestada, privilegia uma interlocução com o cinematismo eisensteiniano, onde fundamentalmente "o pensamento humano é montagem e a cultura humana é resultado de um processo de montagem onde o passado não desaparece e sim se reincorpora, reinterpretado, no presente" (AVELLAR, p.8, in EISENSTEIN, 2002) ${ }^{19}$.

Greenaway, à parte sua insubordinação aos métodos da ilustração, não cria uma ruptura irreconciliável, mas em sentido híbrido propõe a criação de obras no liame entre o banco de dados e a narrativa.

\footnotetext{
17 "A barroca linguagem de fragmentar e mutilar o sentido tornou-se trivial e condenada, mesmo tendo criado uma das artes mais expressivas da nossa história ocidental (devemos lembrar que a arte barroca até Wölfflin era considerada 'arte decadente'). No entanto, a reação iluminista frente à ainda considerada desideração barroca foi cruel: estabeleceram a convenção, a correção e a propriedade dos direitos de autor".

${ }^{18}$ Como ele próprio faz questão de afirmar: "Meu panteão de heróis não é de cineastas [...]. Meus heróis seriam os grandes pintores barrocos como Rembrandt, Caravaggio e Velásquez. São pessoas extraordinárias, com grande senso de visão, o que dificilmente encontramos no cinema". A exceção para Greenaway seria propriamente Eisenstein, quem segundo ele "é o único que poderia ser comparado com Beethoven e Shakespeare sem passar vergonha" (BARCINSKI, 2007). 0 diretor também dedica obras aos pintores barrocos que o inspiram, como "Ronda Noturna", de 2007, e "Rembrandt J'Accuse", de 2008 (ambos a propósito de Rembrandt). E seu último filme (2015), na mesma direção, trata-se de uma cinebiografia de Eisenstein ("Eisenstein en Guajanuato").

${ }^{19}$ EISENSTEIN, Sergei. A forma do filme. Apresentação, notas e revisão técnica de José Carlos Avellar. Rio de Janeiro: Zahar. 2002.
} 
Assim também envereda sua experimentação para a construção de "bancos de dados espacializados" (distribuindo elementos em espaços, desordenados, sem um nexo causal), como em sua instalação de 1992 "100 Objects to represent the world", que consiste mais em uma obra de cunho "catalográfico" do que narrativo mas que, no entanto, culminava em uma ópera onde o personagem-narrador, Adam, utilizava dos mesmos objetos da instalação para criar uma narrativa sequencial (MANOVICH, 2001). Lógica semelhante a sua outra obra hipermidiática finalizada em 2005 e intitulada "The Tulse Luper Suitcases", que resumidamente consistia em três longas metragens (The Tulse Luper Suitacases: The moab story / Vaux to the sea / From sark to finish), uma série de televisão com 16 capítulos, uma websérie interativa ${ }^{20}$ e também uma instalação onde as 92 maletas do protagonista ficavam dispostas ${ }^{21}$. A obra é guiada pela história de Tulse e sua vida é reconstruída a partir das 92 malas encontradas ao redor do mundo. 0 protagonista é descrito por Greenaway como um "prisioneiro profissional", onde o artista propõe tratar do conceito de "prisão" 22 de uma forma metafórica, compreendendo que

It may be that we are all prisoners of something - love, money, sex, fame, religious belief, power, ambition, greed, debt, a job, a garden, a dog, train-time-tables, a mortgage, perhaps just the grocery bill. Consequently most prisons are not rooms with a barred window and a locked door. ${ }^{23}$

Alguns de seus filmes como "O livro de cabeceira" (1996), trabalham com a reticularidade da montagem em multicamadas, como janelas com tempos distintos, alargados, em uma sucessão de temporalidades e de sugestões em um mesmo quadro. Sua espiral coloca o espectador à mercê das múltiplas histórias disponíveis em um banco de dados sendo ofertadas ao mesmo tempo e, embora obedeça uma

\footnotetext{
${ }^{20}$ A websérie anteriormente podia ser acessada pela página http://petergreenaway.org.uk/cgibin/axs/ax.pl?http://www.digiscreen.ca/weblers/tulse/flash.html. No entanto, não encontra-se mais disponível no servidor.

21 No site do artista é possível acessar mais informações sobre a obra: http://petergreenaway.org.uk/tulse.htm. Acesso em: 10/10/2016.

${ }^{22}$ Esta temática, a prisão, mais especificamente a noção de tempo na prisão, também fora tratada em uma hipermídia brasileira, chamada "Valetes em Sllow Motion", de Kiko Goifman, de 1998.

23 Tradução nossa: "É possível que sejamos todos prisioneiros de algo - amor, dinheiro, sexo, fama, crença religiosa, poder, ambição, ganância, dívida, um trabalho, um jardim, um cão, horários de trem, uma hipoteca, talvez apenas a conta do supermercado. Consequentemente a maioria das prisões não são quartos com barras na janela e uma porta trancada". Cf. GREENAWAY, Peter. Tulse Lupper in Turim. 2002.
} 
sequencialidade diacrônica, investe em uma sincronização dos diversos plots/janelas a partir da montagem. Greenaway explora assim a sincronia na diacronia e vice-versa em que, como já apontado por Manovich, centra-se na intersecção do banco de dados e a narrativa. As múltiplas janelas compõe uma montage espacial, a qual (MANOVICH, 2001, p.322), "represents an alternative to traditional cinematic temporal montage, replacing traditional sequential mode with a spatial one"24.
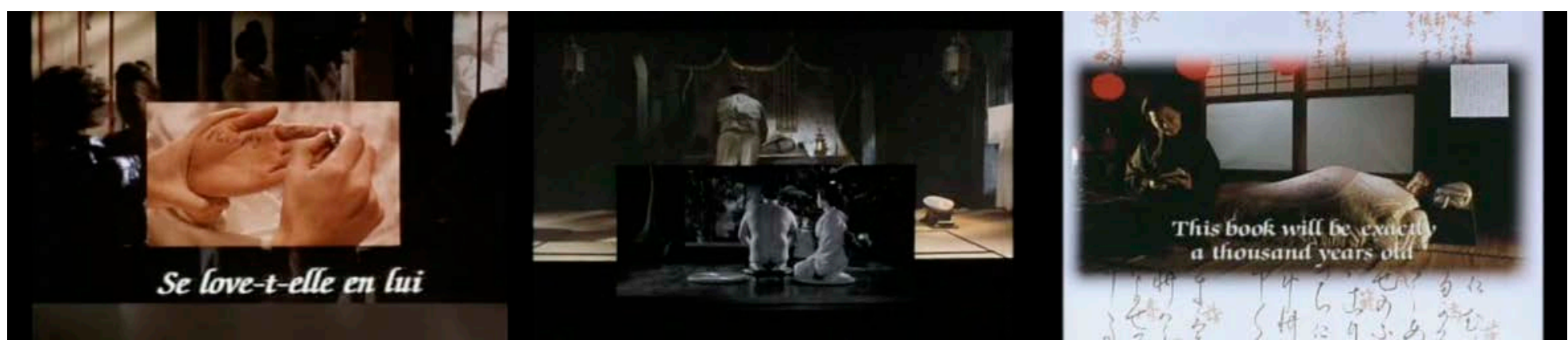

fig. 3 - Três frames de "Pillow book" de Peter Greenaway. Montagem espacial na sobreposição de camadas audiovisuais no mesmo quadro.

O entendimento pleno e unívoco desfaz-se na miríade de nodais que atravessam a história. Do ponto de vista poético, Greenaway acentua ainda uma espécie de intertuaxlidade com a montagem eisensteiniana, em sua relação com a escritura ideogramática que, como escrita no corpo, perpassa todo o filme.

Como Eisenstein já apontava em textos desde a década de 192025 , a lógica multiplicativa do ideograma japonês (e chinês) seria muito mais apropriada às composições cinematográficas do que o princípio fonético das línguas ocidentais. A "montagem", forma de composição, inerente aos ideogramas, pressupõe justapor dois ou mais hieróglifos, onde cada um representa um signo distinto, e o resultado é um produto diferente do que seria simplesmente sua soma. Assim, Eisenstein visualizava uma relação plena com sua intenção de um cinema intelectual, que pudesse provocar o pensamento.

24 Tradução nossa: "Representa uma alternativa à tradicional montagem temporal cinematográfica, substituindo o tradicional modo de sequencialidade por uma espacial".

25 Cf. "Fora de quadro" in EISENSTEIN, Sergei. A forma do filme. Rio de Janeiro: Zahar, 2002. pp. 35-48. Neste artigo, publicado originalmente em 1929, Eisenstein discorre sobre as características da cultura japonesa que lhe parecem oportunas para 0 pensamento cinematográfico. 


\section{Montagens reticulares}

During editing, the editor constructs a film narrative out of this database, creating a unique trajectory through the conceptual space of all possibles films that could have been constructed. From this perspective, every filmmaker engages with the database-narrative problem in every film, althought only a few done so self-consciously. ${ }^{26}$ (Manovich, 2001, p. 237-238)

Para os estudos das novas medias, Manovich sugere a apropriação dos conceitos sausserianos de sintagma e paradigma ${ }^{27}$, compreendendo que em uma narrativa cinematográfica linear, o banco de dados sob o qual a mesma é construída (o seu "material bruto"), uma vez implícito, corresponderia ao paradigma, já a narrativa, ela própria, uma vez explicitada, corresponderia ao sintagma.

No entanto, as novas medias teriam a capacidade de reverter estas posições, onde "database (paradigm) is given material existence, while narrative (syntagm) is dematerialised.28"(MANOVICH, 2001, p. 231). Neste caso, a narrativa seria, portanto, "virtual", desmaterializada, em potência, já o banco de dados seria de onde precederia a "materialidade"29, é portanto material. 0 que nos parece importante desta compreensão é entender que a partir das múltiplas possibilidades de acionamento - sua cadeia de possibilidades -, nas novas medias, podemos aproximar o controle do paradigma do sujeito-interator, este não mais tão somente circunscrito ao autor. Nas novas medias a materialidade precede a virtualidade, ou seja, a materialidade é devir, composta a partir de uma relação interativa.

\footnotetext{
${ }^{26}$ Tradução nossa: "Durante a edição, o montador constrói uma narrativa fílmica fora deste banco de dados, criando uma trajetória única através do espaço conceitual de todos os possíveis filmes que poderiam ter sido construídos. Nesta perspectiva, todo cineasta se envolve com o problema da banco de dados / narrativa em cada filme, embora apenas alguns o façam de forma consciente."

${ }^{27}$ Para uma maior compreensão a propósito destes conceitos dentro da semiologia francesa, Cf. BARTHES, Roland. Elementos da semiologia. São Paulo: Cultrix, 2006.

28 Tradução nossa: "Banco de dados (paradigma) é dar a existência ao material, enquanto a narrativa (sintagma) é desmaterializada."

${ }^{29}$ Manovich (2001) endossa ainda esta posição ao frisar a lógica com que operam os softwares de composição gráfica, sonora e audiovisual nas novas medias, onde, para ele: "A narrativa é construída ligando os elementos desse banco de dados em uma ordem particular, que é projetar uma trajetória onde um elemento leva ao outro. No nível material, a narrativa é apenas um conjunto de links; Os próprios elementos permanecem armazenados no banco de dados. Assim, a narrativa é virtual enquanto o banco de dados tem existência material" (p.231). (tradução nossa).
} 
Nesta lógica, o sujeito-interator detém um novo privilégio, um predomínio "paradigmático". Não seria exagero, portanto, endossarmos a perspectiva de que aquele que controla o banco de dados é, em alguma medida, um montador. Ou um "montador de montagens". Ou seja, na insuficiência da narrativa frente ao banco de dados, é o antigo espectador, agora o montador e maestro da fruição.

Para continuarmos na amplitude da dimensão da montagem nas novas medias, é preciso retrocedermos e observamos a potência para qual Eisenstein eleva o cinema e, por conseguinte, a montgem. A partir de seu conceito de cinematismo, afirma paradoxalmente como sendo a especificidade cinematográfica a sua própria abertura, isto é, seu potencial de inter-relacionar-se com diferentes expressividades estéticas, que não só aquelas convencionalmente afiliadas à tradição cinematográfica (como a literatura e o teatro). A propósito desta concepção em Eiseinstein, Bordwell (2005, p.270) 30 pontua que,

Like Aristotle, he asked certain central questions. At bottom, what is this art of cinema? Eisenstein proposed that it is a form of audiovisual spectacle drawing on representational processes akin to those in literature, music, theatre, and the graphic and plastic arts. How are films made? That is, what are the constituent parts of film, and how do those parts form signifficant wholes? Eisenstein disclosed many suggestive relations of part to part and part to whole: not only various types of editing but also 'montage within the shot', dominant/overtone interactions, 'vertical' sound/image relations, a polyphonic weave of 'voices', and, at the largest scale, motivic 'representations' that contributed to the emergence of an emotion-laden 'image'. And, like Aristotle, Eisenstein asks about the characteristc means ans ends of the art in question. He suggests that the formal devices and systems that he discloses aim ate the maximal excitation of the spectator perceptual stimulation, emotional transport, intellectual awareness; at the limit, ecstasy." 31

\footnotetext{
${ }^{30}$ BORDWELL, David. The Cinema of Eisenstein. Cambridge, MA: Harvard University Press. 2005.

31 Tradução nossa: "Como Aristóteles, ele fez algumas perguntas centrais. No fundo, o que é esta arte do cinema? Eisenstein propôs que se trata de uma forma de espetáculo audiovisual que se baseia em processos representacionais semelhantes aos da literatura, da música, do teatro e das artes gráficas e plásticas. Como os filmes são feitos? Ou seja, quais são as partes constituintes do filme, e como essas partes formam totalidades significativas? Eisenstein revelou muitas relações sugestivas da parte para a parte e da parte ao todo: não apenas vários tipos de montagem, mas também a "montagem dentro do plano", interações tonais/ atonais, relações de som / imagem "verticais", teias polifônicas de "vozes" E, na maior escala, "representações" motivadas que contribuíram para o surgimento de uma "imagem" carregada de emoção. E, como Aristóteles, Eisenstein pergunta sobre os meios característicos e os fins da arte em questão. Ele sugere que os dispositivos e sistemas formais que ele revela, visam a excitação máxima do espectador estimulação perceptiva, transporte emocional, consciência intelectual; No limite, o êxtase."
} 
Nesta compreensão poderíamos afirmar que o cinema não é, portanto, um fenômeno específico, ou que sua especificidade extática é, com suas fronteiras porosas, pois, multíplice, hipermidiática em sua essência: 0 cinema, para Eisenstein são os quadros de El Greco, a lógica de composição ideogramática da escrita japonesa e chinesa, a poesia de Maiakovski e os haikais, o teatro kabuki, a música de Debussy e Scriabin, etc. O cinematismo, portanto, é uma espiral de sentidos, um alicerce da razãosensível para seu objetivo de proposição de uma montagem intelectual. Como refletiria Deleuze (2005, p.192),

Eisenstein lembra constantemente que o 'cinema intelectual' tem por correlato o 'pensamento sensorial' ou a 'inteligência emocional', e se não for assim não vale nada. 0 orgânico tem por correlato o patético. 0 mais alto da consciência da obra de arte tem por correlato o mais profundo do subconsciente, conforme um 'duplo processo' ou dois momentos coexistentes.

Este princípio cinemático é decisivo para a cinematografia eisensteiniana. A indefinição propriamente do campo o coloca em uma perspectiva híbrida, que, como visto em Greenaway, enfatiza a expressão do "cinema além do cinema".

A vanguarda soviética que notadamente primeiro redefiniu a dimensão da montagem, evidenciou, nesta, sua característica sintética, isto é, de sugerir ao espectador a possibilidade de preencher as "lacunas mentais" que podem não estar imediatamente relacionadas, onde há uma articulação possível que solicita um princípio interativo, a ser desenvolvido nos interstícios de fruição, como uma ação de resposta à incompletude ${ }^{32}$. Outrossim, a escultura e a arquitetura, por exemplo, sugerem àqueles que as visualizam, movimentarem-se pelo seu espaço de exibição, interagindo desta forma com o mesmo.

É este reencontro inaugural que durante a década de 1920 constitui a base fértil dos construtivistas. Frente à dimensão de uma arte acabada, tem-se como resposta uma espiral cinemática, hipermidiática, que desencadeia a heterogeneidade, a incompletude. Como em Vertov, potencializa-se a perspectiva de um desvelamento possível, que correlato às suas concepções ideológicas, seria por ele chamado de "decifração comunista do mundo". Em seu filme, “O homem com a câmera" (1929), como pontua

$32 \mathrm{~A}$ possibilidade de um reflexo condicionado a um determinado estímulo, é uma das apropriações que os cineastas soviéticos fazem, em linhas gerais, da teoria comportamental de Pavlov, em voga à época, buscando aproximá-la da montagem. 
Manovich (2001, p. 241), “o paradigma é projetado sob o sintagma”, isto é, o filme opera sob a mesma lógica da criação de bancos de dados, onde

Just as new media objects contains a hierarchy of levels (interfce content, operating system - application, Web page - HTML code, high-level programming language - assembly language - machine language), Vertov film's contains at least three levels. One level is the story of a cameramen shoting material for the film. The second level consists of the shots of the audience watching the finished film in the movie theater. The third level is the film itself, which consists of footage recorded in Moscow, Kiev and Riga, arranged according to the progression of a single day: waking up work - leisure activities. ${ }^{33}$

Além destas características, podemos compreender que a perspectiva que alinhava a cinematografia de Vertov (sobretudo de "O homem com a câmera") a uma relação profícua com a hipermídia, está conjugada propriamente a um devir, em que "tal como Vertov já definira para o cinema, temos também na hipermídia mais uma expansão da incompletude do olhar humano." (BAIRON, 2008). Isto é, o cine-olho é uma potencial relação com o mundo, sempre transitiva e aberta, que expressa e valoriza a dimensão do cotidiano. É o "homem todo mundo" (ibid, 2008), que coordena a ação ordinária da vida na cidade, e que detém, portanto, seu protagonismo.

Bairon (ibid), nota outra possível afinidade na proposição de Vertov com a hipermídia, qual seja, a necessidade constante de dar sentido ao que falta, em que

“[...] A condição à toda criação de sentido está vinculada à renúncia de qualquer condição constituída de linearidade narrativa. A falta constitutiva que se manifesta neste conjunto de rupturas é o que faz daquele que está navegando co-editor da montagem."

\footnotetext{
33 Tradução nossa: "Assim como os objetos das novas medias contêm uma hierarquia de níveis (interfce - conteúdo, sistema operacional - aplicativo, página da Web - código HTML, linguagem de programação de alto nível - linguagem assembly - linguagem da máquina), o filme de Vertov contém pelo menos três níveis. Um nível é a história de um cinegrafista registrando material para o filme. 0 segundo nível consiste nas tomadas da audiência assistindo ao filme terminado na sala de cinema. 0 terceiro nível é o filme em si, que consiste em imagens gravadas em Moscou, Kiev e Riga, organizados de acordo com a progressão de um único dia: acordar trabalhar - e ter lazer".
} 
Bairon (2008) compreende que o desafio da criação de ambiências em hipermídia pressupõe um passo além da dimensão "intracine", pois um filme está para a hipermídia como o fotograma está para um filme, isto é, na hipermídia, há a necessidade de possibilitar o diálogo, por exemplo, entre múltiplas camadas audiovisuais, enquanto no filme, propriamente, há a necessidade de construir uma montagem que conjugue as relações entre suas partes. Manovich (2001) aproxima-se desta compreensão ao pressupor que criar um trabalho nas novas medias, de modo geral, corresponde a pensar interfaces para bancos de dados. Interfaces estas que implicam em construções de montagens sobre montagens. Na lógica digital, a potencial abertura (em uma interatividade aberta), mais do que uma interação cognitiva de uma intra-montagem, sugere ao interator uma ação de registro, de feeddack, "associação exteriorizada" às possibilidades previstas pelo banco de dados.

Fluxos informacionais interativos, camadas de montagens, desmontagens ${ }^{34}: \mathrm{A}$ montagem reticular, quando explorada em ambiências fílmico-reticulares, acentua as características de que as "[...] new media abandons thus 'human-centered' representation altogheter - to put represented time fully under human control. Time is mapped onto two-dimensional space, where it can be managed, analyzed, and manipulated more easily 35 (Manovich, 2001, p. 50).

Em linhas gerais, Vertov ${ }^{36}$, bem como Eisenstein ${ }^{37}$, Rouch $^{38}$, Tonacci ${ }^{39}$, Rosemberg 40 , Tserewahú ${ }^{41}$, Godard ${ }^{42}$, entre tantas outras e outros realizadores, já nos

\footnotetext{
${ }^{34}$ Chamamos de "desmontagem" a noção de descontrução, a partir da reticularidade, da montagem clássica, pressuposta em uma estrutura linear narrativa unívoca. Se nas novas medias o interator atua também enquanto um "montador", em sua montagem condicionada ao banco de dados, a "desmontagem", traduz-se pelo "descontrole", isto é, uma anti-estrutura, consentida em uma potencial partilha da autoria da montagem. A montagem da montagem resulta em desmontagem. Desmontar para montar. Manovich (2001, p. 320), compreende que o interator na novas medias caracterizaria-se como "montador", mas não em sua capacidade de "cortar" - no sentido "tradicional" - senão de "remodelar".

35 Tradução nossa: "[...] novas medias abandonam assim a representação "centrada no ser humano" - para colocar o tempo representado sob o controle humano. 0 tempo é mapeado no espaço bidimensional, onde pode ser gerenciado, analisado e manipulado mais facilmente."

36 As relações entre a criação de banco de dados (BAIRON, 2008, MANOVICH, 2001), como exposto - lógica posteriormente incorporada pelas chamadas novas medias -, e o pensamento cinematográfico foi algo amplamente desenvolvido por Vertov e o Conselho do Três (constituído por ele próprio, sua companheira Elizaveta Svilova e seu irmão Mikhail Kaufman).

37 Embora, em alguma medida, como veremos no capítulo II, talvez os filmes com maior potencial reticular de Eisenstein não tenham sido propriamente produzidos (como por exemplo "Glass House"), seu conceito de cinematismo, como exposto, destacado por Manovich (2001), Bordwell (2005), é fundamental para o alicerce das proposições fílmico-reticulares, em sua espiral de sentidos que aponta para uma compreensão hipermidiática do cinema.
} 
deram inumeráveis mostras de que, a despeito de terem realizado obras "fechadas" em sua possibilidade de navegação interativa, souberam despertar, nas mesmas, um pensamento que está alhures da limitação do suporte.

Este pensamento impulsiona a montagem para o que consideramos aqui, em um primeiro âmbito, enquanto um processo reticular. Seu poderio multíplice de

38 Como veremos no capítulo III, a cinematografia assim como as proposições de Rouch inspiram-nos sobretudo de duas formas: A primeira é no tocante à Antropologia Partilhada, tendo o cinema como sua força-motriz. A segunda é sua constante provocação a propósito da porosidade que permeia o cinema na possibilidade da produção do conhecimento, junto aos próprios sujeitos e comunidades, em um campo onde o livro, por exemplo, seria uma media insuficiente.

${ }^{39}$ Andrea Tonacci, realizador ítalo-brasileiro conhecido a princípio em um período denominado "Cinema de Invenção" (Ferreira, 2016) realiza inúmeras obras relevantes, das quais as que mais nos interessam, aqui, são sobretudo aquelas produzidas na interlocução com povos indígenas. Seu grande filme "Serras da Desordem" (2006), uma espécie de etno-ficção nos moldes de Rouch, consiste em uma audaciosa proposta composta como um complexo jogo de espelhos, que instabiliza as identidades "nativas", do "realizador", bem como explora os limites esponjosos entre as chamadas ficção e não-ficção. A saga de Carapirú e a reencenação de seus (des)caminhos, a plena dialogia entre realizador, equipe e atores sociais, oportuna pensar no liame entre ética e estética a partir do cinema, horizonte este sempre destacado na obra de Tonacci. Seus filmes de temática indígena propiciam reflexões inúmeras a propósito das tragédias produzidas pelo processo colonial no Brasil. O exemplo de "Serras da desordem" (Cf. BAIRON, LAZANEO, 2013) enseja também reflexões sobre possíveis relações entre a reticularidade fílmica e a reflexividade, bem como, antes endossado, da dimensão ética e estética na partilha dos propósitos fílmicos.

${ }^{40}$ Luiz Rosemberg Filho, também realizador do cinema de invenção brasileiro, já realizou mais de 70 filmes. Há algumas décadas dedica-se sobretudo ao curta-metragismo e dispõe toda sua produção integralmente na web, em canais de youtube. Sua lógica de criação fílmica reflete seu processo de colagens manuais, criadas a partir de postais, fotos, recortes de jornal, etc. Embora Rosemberg não produza propriamente estruturas reticulares, é como se no interior de cada uma de suas colagens fílmicas, heterogêneas e descontínuas, encontrássemos sempre à disposição novas possibilidades de ligação e, portanto, de (re)montagens. Sobre sua obra Cf. COELHO, Renato; ESTEVES, Leonardo. (Org.). Rosemberg 70 - Cinema de afeto. 1ed.: , 2015.

${ }^{41}$ Divino Tserewahú é um cineasta indígena xavante com quem dialogamos e criamos conjuntamente há quase uma década no âmbito do Cedipp (Centro de Comunicação Digital e Pesquisa Partilhada). Formou-se como realizador no projeto "Vídeo nas Aldeias". As articulações possíveis de suas obras com os fundamentos da reticularidade fílmica podem ser enfatizadas na dimensão do "filme-processo", como explorado destacadamente em "Sangradouro", de 2008 (Cf. BAIRON, LAZANEO, 2013) e "Mulheres xavante sem nome" de 2009. É como se o processo, invariavelmente sempre inerente à experiência fílmica (seja na dimensão da produção ou da recepção), fosse o objetivo a ser alcançado. Para tanto, Tserewahú utiliza metodologias, como o princípio de feedback, caras à Antropologia Partilhada de Jean Rouch por exemplo.

${ }^{42}$ A obra de Godard compreende um vasto e fundamental compêndio na História do Cinema, com estilos, investigações de linguagem, inflexões inúmeras. Sua natureza reflexiva e multimidiática, inerente a grande parte de sua cinematografia, é o que sublinhamos enquanto um horizonte necessário à reticularidade fílmica. Como lembra Manovich (2002), desde a década de 1960, Godard apresentava em seu cinema uma profusão de "imagens icônicas, música, voz, textos e, por vezes, algo gráfico". Suas "Histoire(s) du Cinèma" (1980-1988), enciclopédias audiovisuais fragmentadas, polifônicas, espiraldas e profundamente filosóficas, são talvez em sua obra aquelas que mais nos apontam uma intersecção entre o cinema e as novas medias. 
acionamento, não restringe-se somente à camada audiovisual, bem como poderíamos considerar que nenhum filme restringir-se-ia tão somente a ela. Não obstante, atua não tão somente como um exercício de preenchimento das lacunas intermitentes, mas a ênfase à reticularidade habita sempre um devir, onde, como exemplo nos autores citados, a limitação do suporte faz com que este processo continue pois no pensamento, em espiral, como refletiria Deleuze em relação ao cinema de Eisenstein, em que

O todo é a totalidade orgânica que afirma opondo e sobrepujando suas próprias partes, e que se constrói como a grande Espiral, seguindo as leis da dialética. 0 todo é o conceito. Por isso o cinema é dito 'intelectual', e a montagem, 'montagempensamento'. A montagem é no pensamento o próprio 'processo intelectual', ou o que, ante o choque, pensa o choque. (DELEUZE, 1995, p. 191)

Assim como são pertinentes as associações entre o cinematismo eisensteiniano, a lógica de criação de banco de dados em Vertov, também compreendemos que algumas das características inerentes às novas medias, de algum modo já podiam também ser vislumbradas em experiências pré-cinematográficas, ao longo século XIX. 0 fenaquitiscópio, o zootropio, o zoopraxiscópio, o fuzil cronofotográfico de Marey, etc, dispunham diferentes imagens ao redor de um círculo. Este princípio de imagens em circularidade nos apontam para lógicas processuais que balizam os modos de funcionamento das novas medias, e comunicam-nos, consequentemente, no princípio da "reticularidade fílmica", como algo não circunscrito tão somente à possibilidade "digital", isto é, operada por processos computadorizados (Interações humano-computador), embora, naturalmente, as ambiências digitais configurem um entorno propício a sua experimentação.

É, neste sentido, portanto, que reforçamos o potencial da "reticularidade fílmica", mais do que relacionada às características imediatas da "interatividade" $H C I$, senão também com a possibilidade da aleatoriedade dos sentidos, presentes com grande ênfase na tradição oral e seu banco de dados do cotidiano . É, neste âmbito, que o saber do mestre griô, que os terreiros da tradição oral, constituem, por excelência, uma amplo território reticular. Na percepção de que as histórias da tradição oral, entrecuzam-se em um leque amplo de possibilidades, valendo-se de diferentes medias (como a própria corporeidade, os instrumentos tonais e atonais utilizados em rituais, cânticos, procissões, etc), obedecendo à justaposições não necessariamente sequenciais, lógicas, 
predeterminadas, mas reivindicando ao seu participante uma potencial "associação exteriorizada". Neste sentido, Manovich adverte para o embate entre a narrativa e o banco de dados, em um sentido que não nos parece distante da tradição oral, em que

[...] as cultural form, the database represents the world as a list of items, and it refuses to order this list. In contrast, a narrative creates a cause-and-effect trajectory of seemingly unordered item (events). Therefore, database and narrative are natural enemies. Competing for the same territory of human culture, each claims an exclusive right to make meaning out of the world. ${ }^{43}$ (Manovich, 2001, p.225).

É este o modo como um hyrít4 karajá, invariavelmente, compartilhará uma história, sentado a frente de seu hetô, próximo ao Rio Araguaia. Dispondo de um diversificado banco de dados, o ser (tão) oral ${ }^{45}$ estará sempre a trair nossa presunçosa objetividade causal. Ao longo dos dias, não sabemos ao certo se os aruanãs ${ }^{46}$ chegarão à aldeia, ou quando chegarão à aldeia, afinal sua vinda depende de uma série de fatores multinaturalistas, nos termos de Viveiros de Castro a propósito do perspectivismo amerídino. A uma pergunta sobre o porquê uma determinada festa vem enfrentando problemas para ser realizada, o hyrí, como quem esquiva-se por uma outra possibilidade de navegação, uma nova janela, em seu feedback, nos conta sobre outro assunto, como quando o espírito do aruanã o "pegou" em uma lagoa e fez assim com que ele desenvolvesse seu dom. Se estivéssemos em uma ambiência hipermidiática, em um percurso fílmico a propósito da investigação sobre um ritual, seria o equivalente a escolhermos um outro percurso, que nos apresentaria histórias outras deste hyrí.

Esta possibilidade poderia ser imediatamente enfrentada por uma suposta linearidade? Compreendemos que sim - como observado em Vertov - na proposição de

\footnotetext{
43 Tradução nossa: "Como forma cultural, o banco de dados representa o mundo como uma lista de itens, e se recusa a ordenar esta lista. Contrariamente, uma narrativa cria uma trajetória de causa e efeito de itens aparentemente desordenados (eventos). Portanto, banco de dados e narrativa são inimigos naturais. Competem pelo mesmo território da cultura humana, cada um reivindica um direito exclusivo de fazer sentido mundo afora".

${ }^{44}$ Como veremos adiante, nos diários de partilha, o hyrí dentro da sociedade iny (karajá) é o correspondente ao xamã.

45 Pegamos aqui emprestado o poético ideograma proposto por Sergio Bairon e José da Silva Ribeiro no filme "Ser tão oral. 0 Ser, tão oral" (2014), a propósito das adjacências que envolvem o ritual de Coroação de Reis Congo que, nas palavras dos autores "são momentos que conversam e versam com o Sertão". Este filme, bem como a série de filmes realizados pela dupla em Brejinho, Minas Gerais, são por sua vez inspirados pela narrativas de Guimarães Rosa. 0 filme está disponível em: https://www.youtube.com/watch?v=qpdiUA3DtOc\&t=83s . Acesso em: 20/09/2016.

46 Os aruanãs (ijasó), como veremos nos "Diários de Partilha", são os espíritos que regulam a vida da sociedade iny.
} 
filmes que conjuguem horizontalidades de sentidos como se pensados fossem na lógica da criação de bancos de dados. Assim como quando somos levados pelos devaneios de Agnes Varda, em seu profícuo documentário “Les Glaneurs et la Glaneuse” (1999), no qual a atividade da "recolha" (também traduzida por "respiga") - objeto central do filme - constitui uma metáfora da própria atividade cinematográfica (subentendida em sua forma de "recolha" de amostras, tomadas do mundo, das pessoas, das histórias a serem contadas) e, por que não, da própria vida e do acaso, sua intangível força-motriz. A realizadora francesa, munida de sua mini-câmera ${ }^{47}$, empreende uma poética investigação a propósito dos sentidos conjugados ao ato de "recolher" aquilo que é dispensado por outrem. 0 filme, portanto, naturalmente depende dos deslocamentos, das escolhas, da sensibilidade da autora, as quais são propostas, não obstante, de um modo reflexivo, compartilhando-as com o espectador que - embora impossibilitado de escolher os caminhos a serem percorridos - torna-se seu cúmplice.

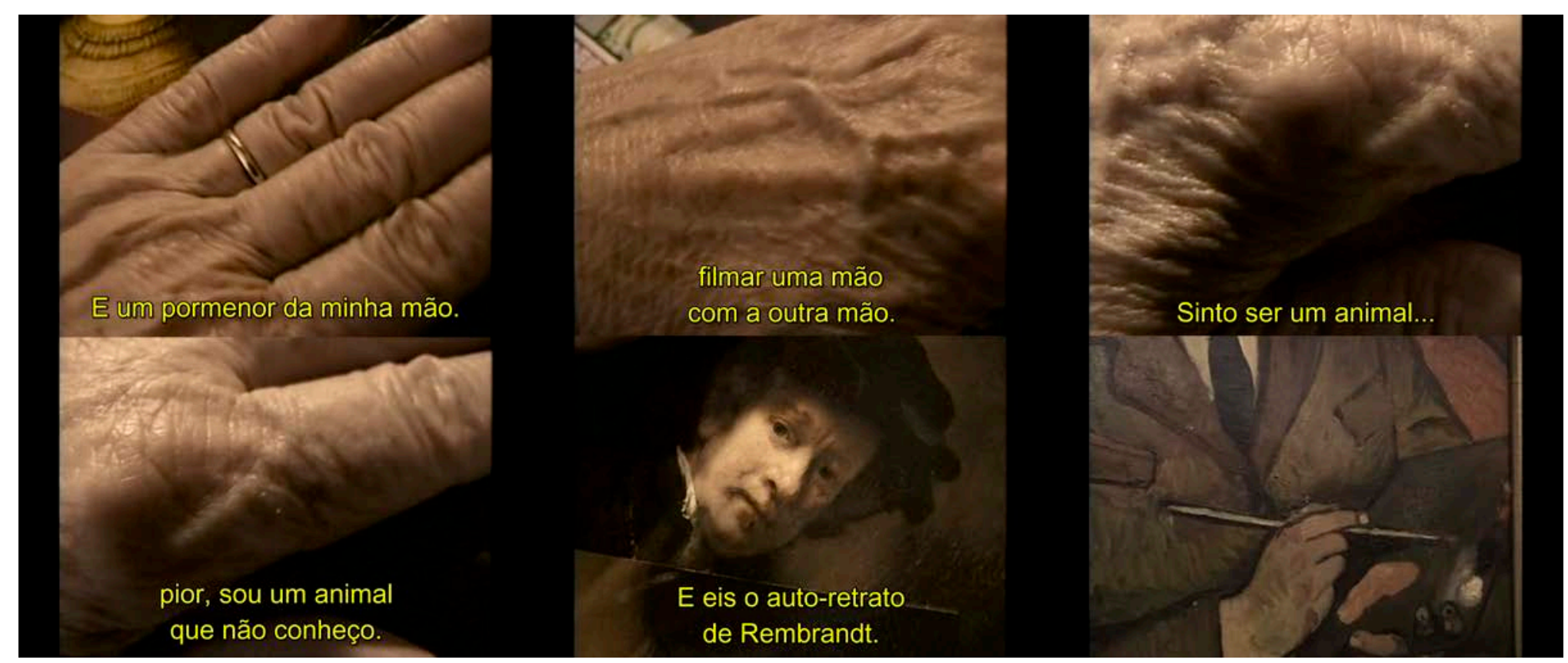

fig. 4 - “É um pormenor da minha mão. E este é meu projeto: filmar minha mão com a outra mão. Entrar nesse horror. Acho extraordinário. Sinto ser um animal, pior, sou um

${ }^{47}$ Ressaltamos que esta característica técnica que poderia passar desapercebida (o uso de uma câmera extremamente portátil), traduz uma sensibilidade necessária à dimensão do sentido do filme. O gesto da "recolha" , da captura do "sensível" (do material ou propriamente do imaterial), demanda parcimônia, leveza, observação sutil. Uma cena notável no filme que aqui destacamos constitui uma reflexão ontológica da realizadora, ao filmar uma de suas mãos, onde a outra naturalmente encontra-se segurando a câmera portátil, ou seja, a reflexão advém também de algum modo da possibilidade de mediação com a pequena câmera. 
animal que não conheço. E eis o auto-retrato de Rembrandt. Trata-se do mesmo e é igualmente um auto-retrato."

Trânsitos de representação em uma sequência de montagem reticular: A reticularidade em Varda propõe o trânsito reflexivo da câmera que observa e faz tomadas de sua própria mão, motor da operação-mental. Esta mesma câmera-sujeito reflete de modo perspectivista: "sinto ser um animal". Ao final da sequência, o autoretrato de Rembrandt é revelado por um movimento sutil da mão que sai do quadro e cria um elo dialógico entre a auto-representação da pintura e a mesma nas tomadas da mão pela câmera coordenada pela outra mão. Do rosto de Rembrandt, passamos para um plano próximo das mãos de Maurice Utrillo, em retrato pintado por Suzane Valladon, em 1921, representações em jogos de espelhos.

\section{A reticularidade no documentário digital interativo}

\section{Dos modos aos novos meios}

Bil Nichols (2012) compreende o documentário sob seis possíveis e distintos modos de representação. Estes modos seriam respectivamente, o poético, o expositivo, o observativo, o participativo, o reflexivo e o performático. Embora não sejam compreendidos de forma diacrônica, visto que tendências de um e de outros modos entrecruzam-se ao longo do desenvolvimento do campo, o autor relaciona as questões pertinentes a cada um dos modos à princípios culturais, sociais, tecnológicos, etc, inerentes à determinadas épocas. É inegável, por exemplo, que haja uma relação principiada a partir de meados da década 1950, com a facilidade de manuseio das novas câmeras portáteis de $16 \mathrm{~mm}$, a capacidade de registro síncrono do som, unida à tendência do modo participativo que veio a se desenvolver no cinema verité francês, bem como do modo observativo, no direct cinema americano e canadense. Assim como, o modo expositivo desenvolveu-se com ênfase no final da década de 1920 e ao longo de toda década seguinte, como um elo entre o cinema e a possibilidade de empreender, a partir do meio, uma "educação das massas"; Portanto uma linguagem clara, objetiva e 
didática fazia-se necessária. Outra contribuição autêntica de Nichols (1991) ${ }^{48}$ aos estudos do documentário é sua definição do campo como uma espécie de jogo entre três perspectivas possíveis: a do realizador, do texto e do espectador.

Na perspectiva do realizador, que seria propriamente autoral, o documentário é visto como um filme realizado por alguém considerado enquanto "documentarista" e, este mesmo, exerce um controle, portanto um jogo de poder sobre o que filma enquanto filma (e edita consequentemente) - embora pudéssemos aqui objetar que esta característica, o controle, não seria evidentemente distintiva na realização de um filme considerado ficcional.

Ao mirarmos a dimensão do "texto", o documentário poderia ser compreendido da mesma forma como um "gênero", o que Nichols coloca como uma definição demasiadamente simplicada, tendo em vista que os diferentes modos percebidos perspectivam ao campo uma vasta heterogeneidade, sob a qual seria redutor construir características genéricas que possam ser comuns a todos os documentários. Já na terceira perspectiva, a do espectador, o documentário deve implicar em uma indexilidade, ou seja, atestar a propósito das relações que suas imagens e sons têm com o mundo histórico, o que, em última instância, deve ser factível para o espectador e, portanto, convincente para o mesmo.

Esta proposta de Nichols, embora pareça-nos conceitualmente atraente, não seria de todo suficiente, pois como o próprio autor sugere, definir conceitualmente "documentário", não é mais fácil do que definir, por exemplo, o conceito "amor"49. Entretanto, sua compreensão dos seis modo possíveis, como salientado anteriormente, sugere uma complexidade ampla à análise do campo e, frequentemente, evidencia as contradições a acompanhar as distintas noções para cada realizador, cada escola, cada documentário e, consequentemente para a recepção.

Por exemplo, a perspectiva do "modo observativo" reafirmava a ideia de que os "[...] documentaristas sempre tiveram o ideal da câmera como um observador imparcial e não incômodo, captando imagens e sons da vida real" (Reynolds apud Da-Rin 2004) ${ }^{50}$.

48 Cf. NICHOLS, Bill. Representing realities. Issues and concepts in Documentary. Bloomington: Indiana University Press. 1991

${ }^{49}$ Cf. NICHOLS, Bill. Introdução ao documentário. Campinas;Papirus, 2012.

50 Esta assunção de uma pretensa "imparcialidade", pressuposta na "objetividade" da captação da "vida real", ensejou valorosos debates também em Antropologia Visual. Um bom exemplo é o artigo que mostra princípios opostos a propósito do uso do tripé em campo, a partir de um diálogo entre Gregory Bateson, Margareth Mead e Stewart Brand, Cf: MEAD, Margaret; 
Rouch, em pressuposto frontalmente oposto, pensa na dinâmica do improviso na condução da câmera e recorre, para tanto, à alusão ao jazz, em que "apenas a posso comparar a esses momentos excepcionais de uma jam session entre o piano de Duke Ellington e o trompete de Louis Amstrong" (Rouch apud Colleyn, 2004).

Da-rin (2004, p. 141) chama atenção para o que seria uma "releitura teleológica da tradição documentária" presente nas premissas dos realizadores e ideólogos do "cinema direto" (como Albert e David Maysles, Pennebaker, Leacock, etc), mais circunscritos às dinâmicas do modo observativo, reencontrando em alguma medida as primeiras experiências dos Lumière, nos primórdios do cinematógrafo. Já Rouch e a tradição do cinema verité - alicerce do "modo participativo" - subentendem que a verdade do encontro é sempre o produto da relação, portanto contrário a uma pretensa objetividade da câmera, os realizadores do cinema-verdade invariavelmente participam, interagem, revelam-se também enquanto atores sociais do todo complexo do filme.

Estas distintas compreensões dizem respeito ao mesmo campo, o do documentário, e evidenciam, portanto sua incompletude, onde talvez repouse sua maior qualidade, sua incessante busca por sentidos.

Não pretendemos, porém, enveredar por certames amiúde irresolutos, tanto na tradição dos realizadores bem como no âmbito teórico, não obstante toda a riqueza conceitual implicada nestes debates. Mas, de outro modo, salientar características que contribuam para a fundamentação do conceito de "reticularidade fílmica", o qual, embora não se restrinja ao campo "não ficcional", portanto do "documentário"51, é neste escopo, onde encontramos um amplo lastro para a proposição da Produção Partilhada do Conhecimento.

Neste sentido, uma contribuição importante pode ser encontrada na direção do documentário digital interativo, sobretudo nos aspectos salientados por Gauzenzi de que

a digital interactive documentary not only uses a digital support (that could be anything from digital video to mobile phones or the Web...) but it also demands some embodied interactivity from the

BATESON, Gregory. "'For God's sake, Margaret', conversation with Gregory Bateson and Margaret Mead" (by Stewart Brand). The CoEvolution Quarterly, California, University of Pensylvania, 1976, June, no. 10 (published by the Whole Earth Catalog), pp. 32-44. 1976

51 Ainda sobre esta tentativa de definição do campo, Cf. CAIXETA, Rubens, GUIMARÃES, César. Pela distinção entre documentário e ficção, provisoriamente. In: COMOLLI, Jean-Louis. Ver e poder A inocência perdida: Cinema, Televisão, Ficção, Documentário. Belo Horizonte: Editora UFMG. 2008. 
user-participant (in other words a participation that is more than the mental act of interpretation)..$^{52}$ (2013, p. 14)

A autora compreende que no âmbito do documentário digital interativo, o usuário seria "agenciado", nos termos de Murray53, o que o tornaria propriamente um "interator" ou "atuante":

For example, their interactive nature demands an active participation of the user who, de facto, becomes a doer, rather than a viewer. The user needs to act on, interact with, the interactive documentary for it to materialize itself into a new screen. The user is therefore not external but rather internal, "part of" the system." 54 (GAUDENZI, 2013, p.15)

Sucintamente propõe que "qualquer projeto que deseje documentar o 'real', e o faça utilizando uma tecnologia digital interativa, pode ser considerado um documentário interativo"55, (GAUDENZI, 2013, pp.31-32), sugerindo que este princípio está baseado na característica "nativo-interativa" e na "intenção de documentação" por parte do autor. Outra característica distintiva entre o documentário "linear" e o "interativo", não seria propriamente a passagem do analógico para o digital mas, mais do que isto, a passagem da linearidade para a interatividade, o primeiro demandando uma participação cognitiva (interpretativa) do espectador, e o segundo "decisões que são traduzias para uma ação física como movimentar, clicar, falar, comentar, etc" (ibid, p. 32).

Uma outra contribuição da autora, diz respeito a uma interlocução proposta com Nichols em que, se na tradição do documentário o autor compreende os seis "modos de

\footnotetext{
52 Tradução nossa: "Um documentário digital interativo não só usa um suporte digital (que pode ser qualquer dispositivo de vídeo digital para telefones celulares ou a web), mas também exige alguma interatividade incorporada do usuário-participante (em outras palavras, uma participação é mais do que um ato mental de interpretação). Neste excerto a autora, de forma sintética, introduz características dos modos do documentário interativo, onde, por exemplo, "interatividade incorporada" corresponde ao modo experiencial.

53 Murray, Janet. Hamlet on the Holodeck. The Free Press. 1997. Citado por GAUDENZI (2013).

54 Tradução nossa: "Por exemplo, sua natureza interativa exige uma participação ativa do usuário que, de fato, se torna um realizador, ao invés de um espectador. 0 usuário precisa agir, interagir com o documentário interativo para que ele se materialize em uma nova tela. 0 usuário não é, portanto, externo, mas sim interno, parte do sistema".

550 destaque na palavra "real" da própria autora, que é compreendido para ela enquanto "qualquer material mediado (onde a mediação possa acontecer a partir de nossos sentidos, nossa mente ou nossa media), que façamos sentido por - ou façamos sentido através estabelecer uma relação de significado com o que nos rodeia." (GAUDENZI, 2013, p. 32) (Tradução nossa).
} 
representação", para Guadenzi, há na interatividade do documentário, portanto, os "modos de interação". Sua taxionomia propõe os modos conversacional, hipertextual, participativo e experiencial.

O modo conversacional pode ser primeiramente notado nas experiências ocorridas no âmbito do Negroponte's Medialab. Nos idos dos anos de 1970, este medialab desenvolveu filmes interativos que focavam na possibilidade de simular situações, como por exemplo andar pela cidade de Aspen, em “The Aspen Movie Map"56, embora, como salienta Gaudezni, este nunca tenha sido abertamente considerado um documentário interativo.

O modo conversacional coloca o interator em função semelhante a de um jogador, e espera dele as ações em uma realidade simulada digitalmente. A conversação, na acepção da autora, compreende que "[...] to interact with a world is like conversing with it: it is open to endless possibilities (impression of infinite database) and both the user and the environment react in real time to each other"57 (GAUDENZ, 2013, p.41), este princípio que define o modo é herdeiro da concepção de Lippmann de que o modelo a inspirar a HCI é o da "conversação" em lugar da "leitura"58. A autora identifica uma clara aproximação com a estrutura dos "games", reconhecendo que o documentário interativo conversacional pode possuir "a lógica de um game", em que "it is only when a factual game, or narrative, tries to simulate reality through a designed $3 \mathrm{D}$ world that I will consider it a conversational documentary"59 (ibid, p. 43).

No modo hipertextual, a lógica da "co-criação" entre interator e autor que baliza o modo conversacional dá lugar ao papel do "convidado". 0 interator é como um

${ }^{56}$ Cf. NAIMARK, Michael. Aspen the Verb: Musings on Heritage and Virtuality. Special issue on Virtual Heritage. MIT Press. 2006. Disponível em: http://www.naimark.net/writing/aspen.html. Citado por Gaudenzi (2013). Acesso em: 10/07/2016.

57 Tradução nossa: "[...] interagir com um mundo é como conversar com ele: esta aberto a infinitas possibilidades (impressão de banco de dados infinito) e tanto o usuário como o ambiente reagem em tempo real uns aos outros."

${ }^{58} \mathrm{HCI}$ - Human Computer Interaction, Interação Humano-Computador. Gaudenzi cita esta definição de "conversação" para Lippmann, diretor do "The Aspen Movie Map", a partir de uma conversa com Brand publicada no livro The Media Lab. Cf. BRAND, Stewart. The Media Lab. London: Penguin. 1998.

59 Tradução nossa: "é somente quando um jogo factual, ou narrativa, tenta simular a realidade através de um mundo projetado em 3D que considerarei um documentário conversacional." 
convidado a navegar por um "conjunto de possibilidades", articuladas em uma ambiência de fruição hipertextual. A autora atribui a este modo a noção de "hitchhiking", isto é de "carona", é como se o interator pegasse carona durante sua navegação nas possibilidades ensejadas pelo autor, em que "what all hyperlink projects have in common is the attempt to portray a factual reality through a searchable archive, or database"60 (ibid, p. 53). Este modo em especial, talvez traduza aquilo que Manovich (2001, p.66), compreende enquanto uma forma de funcionamento das novas medias que assemelha-se às operações mentais.

\begin{abstract}
Interactive computer media perfectly fits this trend to externalize and objectify the mind's operation. The very principle of hyperlinking, which form the basis of interactive media, objectifies the process of association, often taken to be central to human thinking. Mental process of reflection, problem solving, recall, and association externalized, equated with following link, moving to a new page, choosing a new image, or a new scene. Before we would look at an image and mentally follow our own private association to other images. Now interactive media asks us instead to click on a image in order to go to another image. Before, we would read a sentence of a story or a line of a poem and think of other lines, images, memories. Now interactive media asks us to click on a highlighted sentence to go to another sentence. In short, we are asked to follow pre-programmed, objectively existing associations. ${ }^{61}$
\end{abstract}

Assim, são as pré-definições articuladas pelo autor que suscitarão as escolhas do interator a partir do clique em uma palavra, da resposta a um enunciado, do movimento do mouse, de uma escolha em um menu, etc, em que diferentemente do modo conversacional, "[...] the environment is not unpredictable anymore, it is just explorable.

60 Tradução nossa: "O que todos os projetos de hiperlink têm em comum é a tentativa de retratar uma realidade factível através de um arquivo ou banco de dados pesquisável".

61 Tradução nossa: "A media interativa computadorizada encaixa-se perfeitamente nesta tendência para externalizar e objetivar o funcionamento da mente. 0 próprio princípio dos hiperlinks, que forma a base da media interativa, objetiva o processo de associação, muitas vezes considerado fundamental para o pensamento humano. Processo mental de reflexão, resolução de problemas, rememoração e associação exteriorizada, equiparado com o próximo link, movendo-se para uma nova página, escolhendo uma nova imagem ou uma nova cena. Antes, olharíamos para uma imagem e mentalmente seguiríamos a nossa própria associação para outras imagens. Agora, a media interativa nos pede para clicarmos em uma imagem a fim de irmos para uma outra imagem. Antes, leríamos uma frase de uma história ou uma linha de um poema e pensaríamos em outras linhas, imagens, memórias. Agora, a media interativa nos pede para clicarmos em uma frase destacada para irmos para uma nova frase. Em suma, somos convidados a seguir associações pré-programados objetivamente existentes." 
The logic is the one of conscious choice"62 (ibid, p. 50). Por fim, podemos compreender que o modo hipertextual valoriza uma forma de ação processual em que "gives no guarantee of arriving at destination, or of having an interesting journey, it assumes that the journey is the most important part of the experience, and that the user enjoys constructing her itinerary"63 (GAUDENZI, 2013, p. 53).

Esta última compreensão, no entanto, não nos parece distintiva apenas a este modo, senão uma característica peculiar ao documentário interativo (e por extensão, ao diálogo entre o cinema e as novas medias) em que poderíamos considerar, de forma geral, o processo como dimensão fulcral, na medida em que cada navegação é resultado de escolhas, sejam elas conscientes ou inconcientes, a partir de cliques, ou a partir dos olhares ou movimentos em um espaço ou mesmo na nosso própria participação locativa, em que cada interator desenvolve um ação distinta e, a soma destes percursos, em sua fruição tecnológica, parece conferir-lhe um sentido diferenciado, na direção daquilo que compreende Canevacci64 (2012), isto é da característica de que a cultura digital possui em "criar" uma "aura ubíqua", presente na possibilidade de uma "RAD" (Reprodutibilidade Aurática Digital), irreproduzível e reproduzível no mesmo espaçotempo.

No modo participativo, sua diferença fundamental para o modo hipertextual constitui a noção de que, embora possua uma lógica semelhante de navegação a partir de hiperlinks, expande seu banco de dados à medida que mais conteúdos são adicionados pelos interatores. Em sua estrutura o "[...] author decides on the tools and rules and lays down the first layer of bricks, but there is room for collaboration and expansion. The function of the user is both explorative and configurative"65 (GAUDEZNI,

62 Tradução nossa: “[...] o ambiente não é mais imprevisível, é apenas explorável. A lógica é a da escolha consciente".

63 Tradução nossa: "Não oferece a garantia de chegar ao destino, ou de ter uma viagem interessante, assume que a viagem é a parte mais importante da experiência e que o usuário aprecia construir o seu itinerário".

${ }^{64}$ CANEVACCI, Massimo. Digital Auratic Reproducibility: Ubiquitous Ethnographies and CommunicationalMetropolis, An Ethnography of Global Landscapes and Corridors, Diponível em: http://www.intechopen.com/books/an-ethnography-of-global-landscapesandcorridors/digital-auratic-reproducibility . 2012. Acesso em: 03/03/2016.

65 Tradução nossa: "O autor decide sobre as ferramentas e regras e estabelece a primeira camada de tijolos, mas há espaço para colaboração e expansão. A função do usuário é explorativa e configurativa". Nota: Utlizamos "explorativa" e "configurativa", na tradução para o português, 
2013, p. 56). Neste modo, participação não é sinônimo apenas de interação, mas pressupõe processos de criação, modificação e circulação do conteúdo de forma partilhada. Estas ações, no entanto, não resumem-se apenas ao momento de navegação pelo documentário interativo já que podem, de outro modo, compreender a participação em seu processo produtivo (por exemplo na pré-produção). Isto fica evidente no caso de documentários interativos como "Out My Window"66, em que sua interface apresenta a lógica do modo hipertextual, mas, no entanto, seu processo de criação foi amplamente participativo. Um outro exemplo é "ConText"67, em que

[...] content is presented when the system detects idleness from the viewer. Thus, the story moves only when the viewer stops interacting. Content continues to be presented until the viewer stops it by clicking or moving the mouse over the interface to alter the story context. ${ }^{68}$ (ibid, p. 54)

O modo interativo experiencial cria espaços dinâmicos, os quais a autora nomeia de "espaços de experiência afetiva". Este modo subentende uma media locativa, isto é, uma media que detém uma relação com um espaço físico, um lugar, e o processo experienciação se dá nesta co-relação física e digital. Em suma, o modo experiencial deve "affects the perception of physical space, and therefore transforms it for the user"69 (GAUDENZI, 2013, p. 65). São documentários interativos onde o sujeito somente poderá acessar ou recuperar determinado conteúdo quando estiver andando por uma localidade determinada. De acordo com a autora (ibid, p.63), "when a physical environment is mediated by a locative documentary new constraints, and new affordances, are added to the relation participant-environment"70. Este princípio do

visto que na nossa compreensão, "exploratório" e "configurável" poderiam sugerir sentidos imprecisos para o enunciado.

66 No capítulo seguinte analisaremos "Out my Window", um documentário 360ำ decorrente do Highrise Project.

${ }^{67}$ Elaborado a partir de 1995 pelo grupo de cinema interativo do MIT. É também compreendido como um "documentário evolutivo" e que permite novas inserções em seu banco de dados.

68 Tradução nossa: "o conteúdo é apresentado quando o sistema detecta a ociosidade do visualizador. Assim, a história se move apenas quando o espectador deixa de interagir. 0 conteúdo continua sendo apresentado até que o espectador o pare clicando ou movendo o mouse sobre a interface para alterar o contexto da história".

69 Tradução nossa: "afetar a percepção do espaço físico, e depois transformá-lo para o usuário".

70 Tradução nossa: "Quando um ambiente físico é mediado por um documentário locativo, novas restrições e novas percepções são adicionadas à relação participante-ambiente". Nota: Aqui traduzimos o conceito "affordances" para "percepção". A palavra, sem tradução precisa para o 
documentário interativo pressupõe uma "interação incorporada", o que configuraria uma experienciação do espaço tomando uma nova consciência a seu propósito.

Diante da definição dos modos e da amplitude do documentário digital interativo, de outa forma, nos parece necessário refletir sobre aquilo que Manovich adverte como o perigo de uma interpretação literal contida na ideia da interatividade enquanto expressa tão somente pelas relações configuradas por dispositivos tecnológicos ("apertando um botão, escolhendo um link, movimentando seu corpo", etc) ${ }^{71}$. Deste modo, propõe situála conceitualmente de forma não restritiva às novas medias, que operam com diversas formas de interatividade. Outrossim, é certo que Gaudenzi (2013) compreende a interatividade em uma abrangência maior, no entanto busca situá-la em relação à $I H C$ (Interação humano-computador). Assim, na perspectiva de Manovich, a interatividade poderia, por suposto, ser pensada desde o teatro, das orquestras musicais, das artes visuais, a partir da intenção, por exemplo, de Eisenstein - em seu projeto de filmar “0 Capital” de Marx - de propor uma espécie de interação, pré-configurada, objetivando "externalizar" e "controlar" o pensamento do trabalhador, a fim de que se pudesse ensiná-lo a pensar dialeticamente.

O que nos parece importante notar no escopo do documentário digital interativo e sua taxionomia, como proposto por Gaudenzi, são as diferentes formas como a interatividade se adequa às proposições fílmicas e cria novas percepções e possibilidades. Neste sentido compreendemos que os modos sugeridos pela autora são desejáveis para as ambiências que compreendam processos de Produção Partilhada e Reticularidade Fílmica.

português, diz respeito à qualidade do indivíduo em perceber a função de um determinado objeto em um ambiente, seja de forma intuitiva ou por experiência anterior.

${ }^{71}$ Neste sentido, Manovich trata com cautela o que chama de "mito da interatividade", ou seja a ideia associada às novas medias de que "em contraste com as velhas medias onde a ordem de apresentação é fixa, o usuário pode agora interagir com um objeto midiático. No processo de interação o usuário pode escolher quais elementos exibir, ou que caminhos seguir, gerando assim um trabalho único. Desta forma, o usuário torna-se co-autor do trabalho" [tradução nossa] (2001, p. 55). 0 autor, precavidamente prefere evitar - ou sempre utilizá-los acompanhados de alguma qualificação - o uso do conceito "interatividade", assim como "digital", por considerá-los demasiadamente amplos de significação. Sugere, para ser mais específico, conceitos como "interatividade baseada em um menu", "escalabilidade", "simulação", "interface-imagética", "imagem-instrumento", "interatividade aberta" e "interatividade fechada". (ibid, p. 56). 
O modo conversacional, por exemplo, adequa-se à princípios da tradição oral em seu pressuposto de uma interatividade dinâmica, que produz uma navegação imersiva, indefinida, como uma “conversação" em que há a impressão de uma intangível finitude.

O modo hipertextual opera como uma lógica cognitiva, a partir de uma espiral possível de escolhas, em que o intertor, enquanto convidado, descobre o habitar na medida em que relaciona-se com o mesmo. Pelo princípio da predeterminação, atua também na direção de propor uma navegação orientada a possíveis princípios causais que, não obstante estejam no vasto horizonte de sentidos à disposição do interator, podem contribuir para a compreensão de algo, como proposições que envolvam epistemologias construídas conjuntamente entre universidade e comunidade, um princípio caro à Produção Partilhada do Conhecimento.

O modo participativo com amplo lastro em uma proposição participativa, indica uma dimensão necessária às Produções Partilhadas em potencialmente configurarem-se enquanto redes abertas, dialógicas, onde a reticularidade fílmica assuma efetivamente uma perspectiva de co-criação, e que portanto a heterarquia pressuposta na ambiência e na forma de produção, legitime o processo de produção de conhecimento.

0 modo experiencial, por fim, endossa em perspectiva semelhante ao conversacional, um princípio imersivo que pode colaborar a uma redefinição dos loci que perpassam o filme e a narrativa dos sujeitos / atores sociais, isto é, potencialmente gerar novas formas de participação e criação que explorem os limites entre a virtualidade e a não-virtualidade, o material e o imaterial, e que, por exemplo, possam traduzir dinâmicas culturais, rituais, experiências estéticas, reflexões diversas, aos locais onde estas manifestações de algum modo pertençam e ocorram. 


\title{
Linearidades e multilinearidades
}

\author{
No fio \\ de teia, navalha ou lira \\ de linha de língua ou linguagem \\ na alça ou massa de mira \\ DO DESAFIO72 \\ (Ezra Pound)
}

Curiosamente, no léxico das novas medias, da comunicação digital e do cinema, são mais comumente compreendidas enquanto "não lineares" narrativas onde os plots não apresentam um encadeamento lógico causal, em que reine o princípio da causaefeito. No âmbito das narrativas digitais não-lineares, um "texto não-linear" é, para Aarseth (1994, p.57), "a work that does not present its scriptons in one fixed sequence, whether temporal or spatial" - where a 'scripton' is 'an unbroken sequence of one or more basic elements of textuality' $\left(1994\right.$, p.57) ${ }^{73}$

No tocante às ambiências fílmico-reticulares, parece-nos importante dissociarmos a ideia de linha da ideia imediata de sequência. Isto é, o que consuetudinariamente tem-se chamado de "não linear", atrela-se à ideia de uma pressuposta "não-sequencialidade", embora possamos em alguma medida entendermos que as linhas não deixam de existir. Destarte, privilegiamos contrariamente a noção de "multilinearidade" frente à "alinearidade", onde a primeira apresenta uma horizontalidade de possibilidades, enquanto a linearidade ${ }^{74}$ e seu antônimo, a nãolinearidade (alinearidade), configuram uma verticalidade de sentidos de algum modo rígida e predeterminada em seu suporte. A esta noção de que “[...] numa rede hipertextual não há centro nem linearidade. Entrecruzam-se vários centros, vários

\footnotetext{
72 Pound, Ezra. Os cantos. Tradução de José Lino Grünewald. Nova Fronteira: 2006. p. 20.

73 Tradução nossa: "Uma obra que não apresenta seus scriptons em uma seqüência fixa, seja temporal ou espacial" (Aarseth, 1994). O autor entende por "scripton", "uma seqüência ininterrupta de um ou mais elementos básicos de textualidade" (ibid, p.57). Cf. AARSETH, Espen J. Nonlinearity and Literary Theory. In: Landow, George ed. Hyper/Text/Theory. Baltimore: John Hopkins University Press. 1994. pp. 51-86.

${ }^{74}$ Em língua portuguesa, o substantivo feminino linha, de onde deriva linearidade (seu caminho), pode, por exemplo, ser compreendida como a linha constituída por um fio, material este que pode, invariavelmente, ao longo de seu percurso, não configurar-se enquanto uma reta. Isto é, linha e reta não são sinônimos. A "linha torta", aquela que foge do padrão, condenada nos ensinos de caligrafia, seria, por suposto, o desejável no "perder-se reticular" em uma "espiral de sentidos". A linha torta é mais do que a parábola e a elipse.
} 
caminhos e sentidos" (PAIS apud NUNES 2008, p. 39), contraporíamos na perspectiva de que as linhas (portanto caminhos) não deixam de existir mas, pelo contrário, multiplicam-se na fruição orquestrada pelo interator no instante da navegação. Algo já foi dito na perspectiva mcluhaniana de que no digital, isto é, na reticularidade do mundo, não há centro nem periferia. Haveria portanto uma dimensão operativa de fluxos e a comunicação entre os mesmos é, pois, um cruzamento ininterrupto de linhas e de nós.

Portanto, parece-nos que nas ambiências fílmico-reticulares não é a ideia de linha que deva ser desdita, já que este binômio mostra-se insuficiente; senão reafirmada a ideia das distintas potencialidades, onde o domínio da linearidade é aquele por onde se apresentam estruturas sólidas e verticais de linhas exíguas e pré-compostas, rígidas em função de sua perspectiva espaço-temporal, e o domínio da multilinearidade é aquele que exponencializa sentidos horizontalmente, onde opera sobre a capacidade de "controle" do interator, um "descontrole" da sequencialidade predeterminada, portanto da efetivação de uma narrativa, onde as potencias determinantes atuam no âmbito do paradigma (MANOVICH, 2001), de múltiplas sugestões de novas linhas e composições. Invariavelmente, portanto, linha é linguagem, e fenomenologicamente não há como fugirmos dela.

Seria pois importante repetirmos, de outro modo, a mesma questão: A aleatoriedade (com que se configuram as relações, os encontros, os sentidos com o mundo) é, de algum modo, possível de ser expressa em um percurso fílmico linear?

A ocupação territorial (portanto material) empreendida pelos guarani-mbya de São Paulo, e traduzida em uma experiência fílmica reticular (uma "ocupação digital"), seria possível dentro das limitações da linearidade? Nos parece que sim, embora de outros modos, é evidente.

Suspeitamos de que, nestes caminhos, a grande contribuição das ambiências reticulares, construídas com o objetivo de abrigar propostas fílmicas, reside não em sua dimensão narrativa ${ }^{75}$ (embora pudéssemos - e seria desejoso - enveredar pelas

\footnotetext{
75 Manovich (2001, p. 228) com base nos estudos da narratologia de Mieke Bal, vai além e critica o pressuposto de que, nas novas medias, bastaria construir uma ligação entre os registros de um banco de dados onde mais de uma trajetória fosse possível, para construir uma "narrativa interativa". De acordo com o autor, "[...]merely to create these trajectories is of course not sufficient; the author also has to control the semantic of the elements and the logic of their
} 
inúmeras hipóteses acerca da recepção de narrativas lineares frente às multilineares ${ }^{76}$ ), senão em sua relação ambivalente, alargada, construída durante a fruição, onde nossas escolhas, enquanto montadores (e portanto articuladores de linguagem), determinarão a vitalidade e os sentidos desta experiência ${ }^{77}$.

Assim como propõe Manovich (2001, p. 293), "the challenge that computer media pose to cinema extends far beyond the issue of narrative. Computer media redefine the very identify of cinema"78. Ou seja, ao instabilizar o princípio que vincula cinema e narrativa (em seu potencial interativo), as novas medias propiciam à reticularidade fílmica uma abertura a interstícios de linguagem, onde o fílmico, como em Greenaway e Eisenstein (em seu sentido cinemático) por exemplo, pode converter-se à fruição da cultura visual (da tradição das artes plásticas), ou mesmo de ruídos/texturas sonoras, de textos conceituais, poéticos, etc.

Não estaríamos de algum modo a experimentar a aleatoriedade da cotidianeidade ao perpassar um percurso fílmico que levaria, em algum caminho, a um texto poético? A um quadro de Velasquez? A um grafismo karajá? A uma experiência de transe (que desafia os limites da etnografia), alhures de um compromisso narrativo, como nas distorções visuais e efeitos gráficos largamente utilizados no filme xamânico "Xapiri"79?

connection so that the resulting object will meet the criteria of narrative" (tradução nossa: "meramente criar essas trajetórias não é, evidentemente, suficiente; 0 autor também tem que controlar a semântica dos elementos e a lógica de sua conexão de modo que o objeto resultante satisfaça os critérios de narrativa").

${ }^{76}$ Qual é o grau de apreensão do conteúdo fílmico, portanto da sucessão de seus eventos, e seus sentidos em uma narrativa multilinear frente à linear? Como se dá a fruição do espectador em uma narrativa linear e como se dá a fruição do interator em um ambiente de reticularidade fílmica (uma vez explorados semelhantes bancos de dados)? Como se dão as fruições coletivas e individuais nas duas propostas? A reticularidade fílmica é mais adequada a uma experiência individual? Estas são algumas das perguntas que poderiam ser realizadas em uma investigação futura.

77 Embora fosse possível objetar que o espectador "clássico" (aquele diante do regime da linearidade narrativa) também tenha em mãos algum controle sob a vitalidade de sua experiência, este goza de uma gama muito pobre de recursos como, em linhas gerais, (sem nos prendermos a demais abstrações) avançar, retroceder, pausar e interromper a fruição. É importante salientar, evidentemente, que nas salas de exibição cinematográficas estas possibilidades encontram-se normalmente ainda mais reduzidas.

78 Tradução nossa: "O desafio que a media computadorizada coloca ao cinema vai muito além da questão da narrativa. A media computadorizada redefine a própria identidade do cinema".

${ }^{79}$ De acordo com Bruce Albert (etnólogo que trabalha há décadas junto aos yanomami), Xapiri, de 2012 - dirigido por Gisela Motta, Leandro Lima, Laymert Garcia dos Santos, Stella Senra e Bruce Albert - é "[...] um filme experimental, inspirado no xamanismo yanomami. Suas imagens foram registradas por ocasião de dois encontros de xamãs na aldeia de Watoriki, Amazonas, em 
Não obstante, não buscamos apartar rigidamente a reticularidade fílmica da tradição cinematográfica que domesticou a linearidade narrativa aos seus propósitos e que convencionou a linguagem audiovisual a seu perímetro de fruição. Como observado no fenômeno das novas medias, a reticularidade fílmica também, pois, hibridiza, ressignifca, redimensiona, paradigmas de medias anteriores, sem atuar em direção imediatamente (ou necessariamente) contrária. 0 que seria proporcional a dizer que, na horizontalidade de possibilidades constituinte dos ambientes fílmico-reticulares, ou seja, na multilinearidade há, inevitavelmente, linearidades, ou seja, nos termos de Manovich (2001, p. 227) "a traditional linear narrative is one among many other possibles trajectories, that is, a particular choice made with a hypernarrative." 80.

Esta compreensão ampliada, como exposto, não vincula à multilinearidade apenas um desenvolvimento tecnológico circunscrito ao digital -, onde a aleatoriedade é sempre um convite - senão, também, e em igual medida, às dinâmicas das culturas de tradição oral, o que nos leva à composição de um ideograma multiplicando os conceitos de aleatoriedade, autoria e oralidade, resultando na proposição da aleautoralidade, isto é, uma dimensão híbrida experimentada na ênfase que a oralidade confere aos seus múltiplos autores, perspectivas coletivas e aleatórias em múltiplas digressões (interrupções, justaposições, sobressaltos narrativos).

março de 2011 e abril de 2012. Entretanto, o trabalho realizado sobre estas imagens escapa do registro documentário a fim de produzir uma simulação tecnológica livre a partir do universo visual e conceitual do xamanismo yanomami. Xapiri não pretende descrever e muito menos explicar o trabalho dos xamãs Yanomami. Deve ser considerado como uma tentativa de tornar sensíveis, através de nossas imagens digitais, certas ideias yanomami sobre as imagens xamânicas (utupë), sua ontologia e sua estética, sua transdução e mutabilidade nos corpos. Trata-se, antes de tudo, de uma homenagem visual à riqueza intelectual e poética do xamanismo yanomami". Este excerto encontra-se na descrição do trailer do filme em uma página do vimeo, disponível em: https://vimeo.com/79411469 Acesso em: 05/11/2016. Em nossa leitura, o filme constitui também um exercício de Produção Fílmico Partilhada na perspectiva de que alguns yanomani, como Davi Kopenawa, trabalharam, enquanto consultores, em estrita cooperação com a equipe de realização. Ou seja, no âmbito estético, a legitimidade conferida por um xamã yanomami aos processos de criação, circunscreve o filme em uma inerente vinculação aos princípios e tradições deste povo, que não são narradas e explicadas dentro de postulados lógico-conceituais, senão oferecidas à sensibilidade do espectador. Em "Xapiri" há, portanto, um valioso encontro entre ética e estética.

80 Tradução nossa: "Uma narrativa linear tradicional é uma entre muitas outras possíveis trajetórias, isto é, uma escolha particular feita com uma hipernarrativa". 
Permutamos gramas de ideogramas à granel, na feira de grãos de linguagem:

Aleatório-autoral-oral, como um portmanteau que alicerça, sem cercear.

Aleautoral.

O aleatório é a senhora do tempo da fala.

Justapõe e espirala novos sentidos, novos autores, novas línguas, e sortilégios do tempo.

Permutamos gramas de ideogramas à granel, na feira de grãos de linguagem: Ancestral-aletatório-autoral-oral.

Nos autos da oralidade na transitória idade, a cama feita de grama, é onde repousa, a aleautoralide.

\section{Da Reticularidade fílmica à Produção Partilhada de Conhecimento}

Como demonstramos em análise a propósito dos trânsitos de representação do filme à hipermídia a partir da temática indígena (BAIRON, LAZANEO, 2013), a reticularidade fílmica, concebida em ambiente acadêmico e com a vista à Produção Partilhada, "questiona as estrutura rígidas e formais da produção do conhecimento científico, que elege as narrativas acadêmicas como o protagonista do Saber", deste modo em um "mesmo ambiente habitam polifonias, em diferentes autoridades de níveis taxionômicos, discursivos e estéticos, sendo que o texto acadêmico continua em sua matriz textual e o produto indígena é o filme". 
Disto decorre uma compreensão de que na proposição híbrida da Reticularidade Fílmica (portanto da criação de ambiências fílmicas hipermidiáticas) com a Produção Partilhada do Conhecimento há, ao menos, uma tendência reequilibradora das assimetrias $^{81}$ produzidas pelo meio científico e sua estrutura político-institucional. Ao relativizar a noção de "verdade" do "método científico", como propõe por exemplo Gadamer (2011) na filosofia da ciência, ou a "verdade" do "erro" como o faz Latour (1994), em sua proposição da antropologia simétrica e na antropologia da ciência, na produção digital-reticular partilhada, não estamos a desvalorizar a importância da ciência, ou melhor, da cientificidade. De outro modo, estamos a valorizar um processo onde a pergunta é construída na interrelação, seja esta entre o sujeito com quem se relaciona o texto / filme / produto científico - onde a navegação pode leva-lo sempre alhures - ou mesmo com as comunidades com quem o conhecimento é partilhadamente construído, como valorizam Bairon e Torres (2009, p. 19), "no âmbito das possibilidade dos média digitais, o leitor/utilizador, longe de se prender na dimensão de uma suposta apreensão de uma verdade qualquer, situa-se muito mais no interior da pergunta do que da resposta".

Neste sentido, a experiência estética configura-se enquanto um vetor essencial e as metodologias de aproximação que (re)valorizam as tradições e medias que vão além do texto, como propriamente a imagem, o som, a voz, o corpo, o batuque, o canto, a batida, a poesia, o chacoalhar de uma maraca, a roda, devem ser indefinidamente buscadas.

A partir da (multi)perspectiva da reticularidade fílmica, enfatizamos, portanto, a potencialidade de que a aleatoriedade dos acontecimentos - onde a possibilidade da (des)montagem fílmica sugira sempre novas composições - pode colaborar com a construção da compreensão de algo, sobretudo no interior fílmico-reticular.

O saber é fruto de um percurso reticular, a reticularidade fílmica é antes, senão, o desdobramento de uma reticularidade epistêmica, de um zapping cognitivo. Para além

\footnotetext{
${ }^{81}$ A propósito da noção de simetria, na antropologia, Viveiros de Castro (2002), reflete sobre que, em uma proposição de antropologia reversa - i.e, aquela realizada a partir do "nativo" -, "a simetria não cancela a diferença, pois a reciprocidade virtual de perspectivas em que se pensa aqui não é nenhuma 'fusão de horizontes'. Em suma, somos todos antropólogos, mas ninguém é antropólogo do mesmo jeito"(p. 141).
} 
do suporte clássico, imersos em reticularidades interativas os sujeitos-naus derivam em um imenso e obscuro oceano, amiúde ressignificado pela montagem do sujeito interator em seu cotidiano. 0 contexto das ditas "novas medias", e sua superlativa capacidade de reunião de "bancos de dados", e o aleatório de seu "jogo de dados", nos imputa à inequívoca condição do devaneio. 0 contexto da oralidade, de uma porção de vida que não obedece fielmente aos ditames da sociedade do trabalho (onde aquilo que chamaríamos "trabalho" opera de outras formas) nos imputa à inequívoca condição do flanar.

Em um simples passeio por uma aldeia, quantas narrativas nos são ofertadas, quantas prosas nos são generosamente narradas? Em um simples passeio pelas ambiências digitais, quantas abas, janelas, novos desdobramentos e fluxos de conhecimento perpassamos ou, esperançosamente, expandimos? A cada simples e nova deriva? A cada novo filme, a cada nova fricção audiovisual, quantas impermanências?

coisa nossa

De tanto heideggarear, o cóisico, em fuga do cógito, precisou tomar um ar.

Estava já sentindo-se sem sentido.

Ficar na Europa? Parto, logo existo!

Juntou suas coisas, e foi para a América do Sul.

Trouxe de presente sapatos de Van Gogh. Morou na Amazônia, tomou ayahuasca com os índios, e depois disso tudo ficou sem saber coisa alguma. 


\section{CAPÍTULO II}

\section{ANÁLISE DE RETICULARIDADES FÍLMICAS}

Neste capítulo recorremos à análise de duas propostas fílmico-reticulares, o documentário 360 "Out My Window" e a manifestação-fílmica-reticular guarani, intitulada "O dia em que paramos a Bandeirantes", assinadas por Katerina Cizek (e o núcleo interativo da NFB) e pela Comissão Guarani Yvyrupa CGY ${ }^{82}$, respectivamente. Para tanto, buscamos relacionar estas análises aos princípios teóricos e taxionomias vistos no capítulo anterior.

Aisendo

Ai se Einstein, Cinematopéico fizesse, Quânticas ideogramarias?

Ai se Eisenstein, Física fizesse, Cânticas ideogramarias?

Ideogramarias, Ideogramar iriam, Ririam, justaporiam, fissurados! Físi(a)calma com cine(a)maria, Física(maria) com cineman'alma

Perguntar ririam... Quântico pesa o grama? Em qual cântico está a alma?

A resposta, justaposta: fuja do gra(as)mático! Aquele que nem ideogramar iria. Já a resposta, bem composta, $\mathrm{Na}$ linguagem estaria.

82 O documentário interativo "Out My Window", pode ser acessado em: http://outmywindow.nfb.ca/ . "Rodovia Rojoko - 0 dia que paramos a bandeirantes pode ser acessado em: https://www.youtube.com/watch?v=JCBOU4wQmR8 . Entretanto, como veremos adiante, a ambiência reticular pode ser também acessada a partir de seus outros eixos (que aqui chamamos de "B" e "C"). 
Quando Eisenstein, em seu período mexicano, resolutamente filmava rolos e mais rolos de filme a fim de finalizar seu projeto, conta-se que seu produtor, Upton Sinclair, em Hollywood, desesperava-se. Afinal, com os quatrocentos quilômetros rodados, que filme se poderia de lá extrair? Quanto maior a quantidade, maior a dificuldade de síntese preza a regra de um eficiente produtor.

A despeito da possibilidade de que incontáveis fatores tenham contribuído para tal, aventamos a hipótese de que o insucesso do projeto ${ }^{83}$ tenha lugar, paradoxalmente, na ideia de que este processo deveria resultar em um filme ${ }^{84}$, além, é claro, da subordinação do cineasta ao pedido de regresso feito por Stalin (que após um ano da filmagem, manifestava à Sinclair que Eisenstein seria já um potencial desertor).

Mais uma vez, a imensa capacidade cinemática de Eisenstein, quando somente impressa a uma rígida sequência de celuloide, mostraria-se insufieciente para o êxito de um projeto auspicioso em sua horizontalidade, em sua dimensão ampliada, multilinear. Seria a forma a contrapor o conteúdo? Ou melhor, estaria o suporte a limitar a proposição, estabelecendo uma margem a este tão fértil cinematismo? A mesma pergunta poderia se fazer a propósito de seu projeto Glass House que, em igual medida, não logrou êxito. Diferente, no entanto, de "Que Viva México!" o projeto da casa de vidro não saiu do papel.

Antes, porém, de nos atermos ao projeto de Eisenstein, estabeleceremos uma outra ligação possível com uma obra contemporânea intitulada "Out my Window" (2010), onde interessa-nos, sobretudo, o diálogo proposto tanto com a linguagem cinematográfica quanto com a comunicação digital, a partir do qual sugeriremos correlações possíveis com os pressupostos da teoria da montagem

\footnotetext{
83 "Insucesso" no sentido de que Eisenstein nunca o finalizou. As montagens posteriores foram feitas utilizando o material bruto do filme após sua morte. De acordo com Bordwell (2005), Eisenstein permaneceu extremamente consternado pelo fracasso do projeto até seus últimos dias de vida (16 anos depois do período mexicano), tendo mantido por todo esse tempo o telegrama de Sinclair - que anunciava o término do projeto -sobre sua mesa de trabalho.

${ }^{84}$ Ainda que composto por diversos episódios, com o objetivo de perpassar a história mexicana dos tempos pré-colombianos, atravessando a conquista espanhola e chegando até a contemporaneidade, onde cada episódio seria dedicado a um diferente artista mexicano, de Posada à Orozco. (Bordwell, 2005).
} 
de Eisenstein e Vertov, assim como metodologias apropriadas à investigação hipermidiática.

\section{A (des)montagem fílmica em "Out My Window"}

Este filme reticular ou - como propõe sua diretora - o "documentário $360^{\circ}$ ”, retrata o cotidiano de famílias habitantes de prédios ao redor do mundo, em 13 diferentes cidades. Poderíamos também compreendê-lo, na taxionomia proposta por Gaudenzi, como um documentário interativo nos modos hipertextual e participativo.

São Paulo, Havana, Praga, Istambul, Bangalore, Phnom Penh, Tainan, Joanesburgo, Beirut, Amsterdam, Toronto, Montreal e Chicago. São 13 as cidades/janelas descortinadas pela diretora canadense Katerina Cizek e sua equipe à frente do projeto Out My Window. Nascido a partir do Highrise Project ${ }^{85}$ - um "documentário multimídia" - configurou-se como um amplo esforço colaborativo - crowdsourcing 86 - de produção, envolvendo jornalistas, filmmakers, fotógrafos, dentre outros interessados, que colaboraram diretamente com a equipe realizadora.

0 percurso, que levou um ano de pesquisa até que a produção efetivamente começasse (em agosto de 2009), selecionou, a partir de uma ampla base de banco de dados, 22 histórias - das quais restaram as 13, das cidades

85 Produzido pela National Film Board, do Canadá, o projeto Highrise é resultado da residência de 5 anos da diretora Katerina Cizek na instituição. A NFB / OFC (National Film Board / Office du film) é uma agência de cinema estatal canadense, fundada, dentre outros pelo documentarista John Grierson, em 1938. Com um núcleo bastante atuante em filmes interativos, a NFB tem se destacado em produções envolvendo o cinema e as chamadas novas tecnologias.

${ }^{86}$ Formada pela junção de crowd (multidão) e source (fonte), a ideia de crowndsourcing compreende um modo online e colaborativo de produção e gestão para diferentes finalidades, como sites, filmes, pesquisas, projetos empreendedores, etc,. Para uma maior problematização: Cf. BRABHAM, Daren. Crowdsourcing as a Model for Problem Solving: An Introduction and Cases. Convergence: The International Journal of Research into New Media Technologies, pp. 75-90, 2008. Gaudenzi (2013), elabora uma reflexão a propósito dos conceitos de crowdsourcing, open source e peer-sourcing, considerando-os imprecisos para se trabalhar com documentários participativos a partir de plataformas digitais, uma vez que, convencionalmente, estes termos ficaram mais associados a criação e gestão de softwares, blog, enciclopédias. 
citadas - e que compõe, assim, um mosaico glocal a propósito da temática da habitação em moradias verticais, em grandes cidades.

Embora as demandas de produção sugerissem um esforço logístico monumental, o método da diretora e de sua equipe compreendeu a criação e montagem a partir de imagens e sonoridades enviadas pelos protagonistas das histórias, via internet ou mesmo correio.

Deste modo, a maior parte do projeto fora solidificado sobre bancos de dados distintos, construídos em rede.

Conforme as histórias foram sendo selecionadas, a equipe e a diretora estabeleciam uma comunicação frequente com os protagonistas e os colaboradores, realizando reuniões e entrevistas à distância, via internet. Em algumas cidades em especial (Havana, Toronto e Amsterdam), a equipe optou por registrar cenas com câmeras $360^{\circ}$ (um mecanismo multi-perspectivista feito a partir da junção de cinco objetivas) que permitem ao interator a possibilidade de uma livre navegação pelo entorno fílmico à medida que o filme avança.

\section{Um prédio, cada janela, uma cidade diferente}

Ao todo, Out my Window traz 49 histórias (das 13 cidades) que totalizam 90 minutos de material a ser descoberto. Diante de tamanha diversidade, inconcebível de ser resumida em uma linearização arbitrária, preestabelecida, descobrimos - e desmontamos - pouco a pouco, sua pluralidade.

Em entrevista concedida à pesquisadora Sandra Gaudenzi, em 2011, a diretora Cizek afirma que:

This is a story that would not necessarily translate well into a 90 minutes feature film. People that are doing films are looking for extremely strong characters that are going through some sort of life changing transformation. There is a beginning, middle and an end to what we witness in the story. Whereas here [in $O M W]$ the units are really very small, they speak about the details, the minutia of everyday life. And that is what I love about the Web, because it honours that everyday experience. I 
think [...]it opens up a whole new series of opportunities in storytelling. (Cizek apud GAUDENZI, 2013, pp. 206-207). ${ }^{87}$

A diretora reafirma, assim, nesse excerto, a vocação absolutamente cotidiana dessa modalidade de cinema. Não estamos nós, por suposto, diante de personagens homéricos, de grandes histórias, vivenciadas por pessoas maravilhosas em caminhos repletos de clímax e redenção.

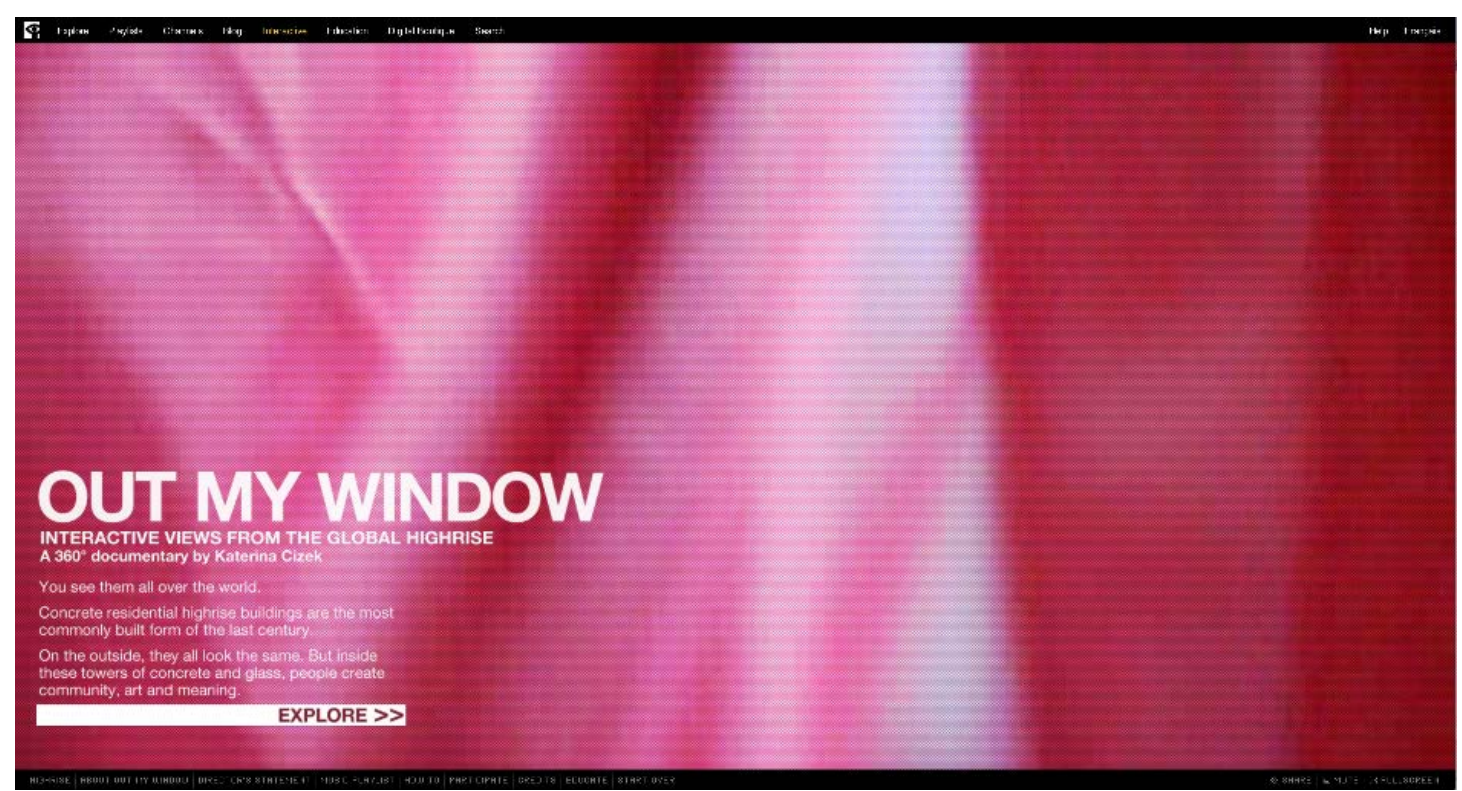

Fig. 5 - Tela inicial de Out my Window.

Logo na recepção ao entorno de Out My Window, avistamos uma cortina balançando ao sabor do vento. 0 clique em "Explore" - sugere a primeira tela -é o que descortinará as experiências propostas. No canto inferior esquerdo, uma breve sinopse comunica: "Vistas interativas de arranha-céus globais. Um documentário $360^{\circ}$ de Katerina Cizek. Você os vê por todo o mundo. Prédios residenciais são a forma mais comum de construção do último século. Por fora,

87 Tradução nossa: "Esta é uma história que não seria necessariamente bem traduzida em um longa-metragem de 90 minutos. As pessoas que estão fazendo filmes estão à procura de personagens extremamente fortes que estejam passando por algum tipo de transformação, de mudança de vida. Há um começo, um meio e um fim para o que nós testemunhamos na história. Enquanto aqui [no OMW - Out my window] as unidades são realmente bastante pequenas, falam sobre os detalhes, as minúcias da vida cotidiana. E isso é o que eu amo na Web, porque honra a experiência cotidiana. Eu acho que ( ... ) ele abre toda uma nova série de oportunidades em contar histórias". (Cizek, entrevista gravada por Gaudenzi em 16.09.11). 
são todos parecidos. Mas no interior dessas torres de concreto e vidro as pessoas criam comunidades, arte e significado" (tradução nossa).

As texturas sonoras polifônicas da tela de abertura combinam diferentes camadas de sons de cidades, pessoas, músicas, sons de pássaros, etc. Embora, neste ambiente, não exista ainda uma proposta de aleatoriedade sígnica durante a interação - já que a mesma camada de imagem e de som são executadas em loop constante -, há, ao menos, a cada nova entrada, uma nova textura sonora sendo executada diante da tela com a mesma cortina.

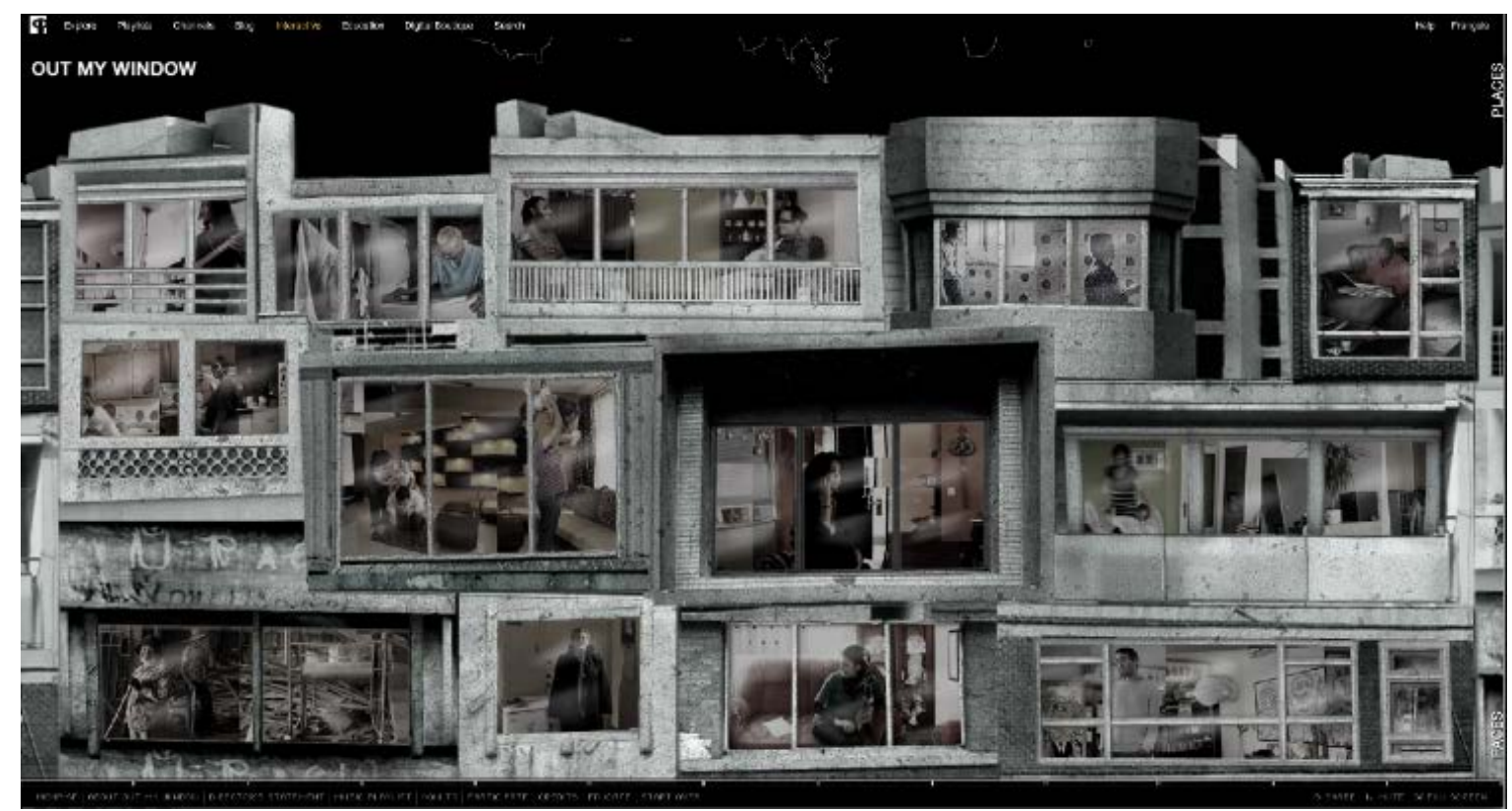

Fig. 6 - One Highrise. Every window, a diferente city. Entorno principal da hipermídia sugere um prédio com três pavimentos (distribuído com quatro histórias / habitações nos dois primeiros andares e 5 no último).

Conforme decidimos efetivamente navegar pelo ambiente - ao clicar em "explore" -, somos levados a um mosaico/composição/montagem de um prédio (cf. Fig.6 ), edificado a partir de três "pavimentos", sendo o primeiro e o segundo com quatro habitações/entorno cada e o terceiro, com cinco, totalizando as treze histórias.

De imediato, muitas possibilidades de navegação descortinam-se a partir das imagens do(s) prédio(s) que se edificam diante de nós. 0 áudio, de modo mais tímido - e cacofônico -, apenas ilustra o passeio livre do mouse, acionando o mesmo caco sonoro quando, respectivamente, estamos com o cursor em cada uma das diferentes habitações. Bairon (2006) sugere, no âmbito técnico- 
metodológico ${ }^{88}$, três diferentes categorias de classificação das imagens que podem fazer parte de um banco iconográfico pertencente a uma estrutura hipermidiática. São as imagens citadas, manipuladas e reticulares.

Para o autor, a imagem citada não pode meramente constituir uma representação de determinado conceito. Deve, contudo, possibilitar ao interator “a ação imersiva da navegação" (BAIRON,2006:57), tal como se "estivéssemos no interior de uma obra de arte". O autor, por fim, classifica as imagens citadas, inseridas em um ambiente hipermidiático, como peças dos “jogos de linguagem”.

A imagem manipulada reforça o aspecto de montagem, colagem enquanto pressuposto da "circularidade sígnica" e "componente essencial" de toda imagem. A manipulação da imagem vai ao encontro de seu próprio esvaziamento, ou seja, da condição de assumirmos a sua incompletude, sobretudo no interior hipermidiático. A "manipulação", nesse sentido, reforçaria a insuficiência das imagens estáticas, expandindo "sempre sua significação para outro lugar, da mesma forma que ocorre com qualquer acontecimento artístico".

A imagem reticular, ou também imagem aberta, imagem caminho, multimargem imagética, deve ser, por excelência, permeada de conexões, como nodais de uma rede "na qual algo de inconsciente tem a oportunidade de continuar sua teia de significações". (BAIRON,2006:58). Sua característica fundamental não deve ser "introdutória", senão interlocutora de novas possibilidades e aberturas.

Em Out My Window, estamos constantemente transitando por essas imagens. 0 prédio global, nosso segundo ambiente de navegação, está edificado por imagens citadas. A obra, em seu menu, é dividida em Places, spaces, faces (lugares, espaços e faces/pessoas), o que nos permite - para acessarmos cada nó - três diferentes possibilidades de ligação. Como principal entorno desse ambiente, o prédio conduz também à ação imersiva e que se dá propriamente na escolha de qual morada (places) primeiramente conheceremos - cada qual, com o passar do cursor, destaca-se, ganhando maior saturação.

88 É importante salientar que a taxionomia, proposta pelo autor, visando contribuir com critérios para avaliação de produções em hipermídia, pressupõe relações filosóficoteóricas, teórico-metodológicas, metodológicas-teóricas e técnico-metodológicas. Cf: BAIRON, Sérgio. Tendências da Linguagem Científica Contemporânea em Expressividade Digital. Cibertextualidades, Portugal - Porto, v. 1, n. 1, p. 53-106, 2006. 
Um mapa global subitamente desce da margem superior da tela (quando passeamos com o cursor por seu cabeçalho), sendo também possível escolhermos uma habitação fílmica diretamente por sua localização nele. 0 percurso aleatório do cursor traz as "faces/pessoas", que emergem da margem inferior, do rodapé, onde também podemos escolher entre os sujeitos protagonistas dos lugares aos quais as histórias referem-se.

Ao passo que selecionamos uma das "faces" (na margem inferior), o mapa (na margem superior) faz notarmos, em vermelho pulsante, a qual lugar do globo pertence cada sujeito. Estratégia não desvelada quando passeamos, ainda sem adentrar, pelas fachadas da habitação (places), que no passar do cursor não encontram correspondência imagética no mapa (spaces) nem nos sujeitos (faces), apenas uma legenda textual no canto superior esquerdo informando-nos a cidade e o país correspondente. Algo que nos sugere que o prédio, como um rizoma edificado, consiste uma metonímia babélica, ao passo que as pessoas e espaços, portanto as identidades étnicas, locais, culturais, raízes (roots) estão inexoravelmente conjugadas às diferentes rotas (routes). Não obstante, como peças dos jogos de linguagem, as imagens citadas dos rostos, lugares e espaços confundem-se, desterritorializando uma pretensa representação. 0 que, de fato, poderia representar cada contexto? Os lugares, as pessoas ou seus espaços no mundo? O signo, dessa forma, reafirma-se três.

Out My Window expõe diversos dilemas glocais, nas diferentes habitações, como o caso dos hijackers em Joanesburgo, África do Sul, onde, narrando em primeira pessoa ${ }^{89}$, John fala sobre um prédio "sequestrado" que ele avista de sua janela (inclusive já tendo vivenciado uma situação similar), no qual os inquilinos convivem com ameaças frequentes em uma cultura bastante violenta, em que qualquer atraso no pagamento é justificativa para dolorosas punições. Assim como o caso do menino Caion, que, junto de sua mãe, fora acolhido pelos moradores de uma ocupação do centro de São Paulo. Na mesma habitação, Ivaneti, a partir da imagem reticular "Pictures of my past/future" narra a

\footnotetext{
${ }^{89} \mathrm{~A}$ narrativa em primeira pessoa, a partir dos interlocutores já conhecidos desde as "faces" da tela inaugural, é uma constante em todas as habitações fílmicas e, naturalmente, consiste um método explorado pela diretora, que, como no Cinema verité, de Jean Rouch, sugere às próprias pessoas falarem de si mesmas e de suas experiências com seu entorno.
} 
complexa questão da moradia no centro de uma metrópole repleta de problemas sociais, onde as camadas mais pobres são constantemente ameaçadas pela gentrificação dos projetos de "revitalização", que tão bem atendem aos interesses da especulação imobiliária.

As imagens manipuladas aqui assumem a função de alimentar uma circularidade sígnica inaugurada desde as colagens na abertura de cada habitação, que, por sua vez, elaboram, de forma palimpséstica, uma complexa sobreposição de imagens e historicidades do entorno. Como puzzles de justaposições em uma montagem flertando com o aleatório, desestabilizam uma relação naturalista, de uma pretensa continuidade do espaço tridimensional. 0 tridimensional, não obstante, atua como uma fruição reticular para o propósito da imersão que, concordando com Bairon (2006), compreendemos com

[...] o processo deflagrado a partir da relação entre a subjetividade expressa na criação dos ambientes digitais e a possível acolhida da subjetividade alheia, fundamentalmente, na forma de relações dialógicas como estranhamentos, buscas, referencias ao cotidiano, abstrações configuradas e interações programadas conceitualmente. Imersão, portanto, é a condição de habitação revelada por toda experiência de construção, que se expressa por meio do jogo da relação de sentido entre ambiente e usuário, entre conceito e experiência. (BAIRON, 2006:56). 


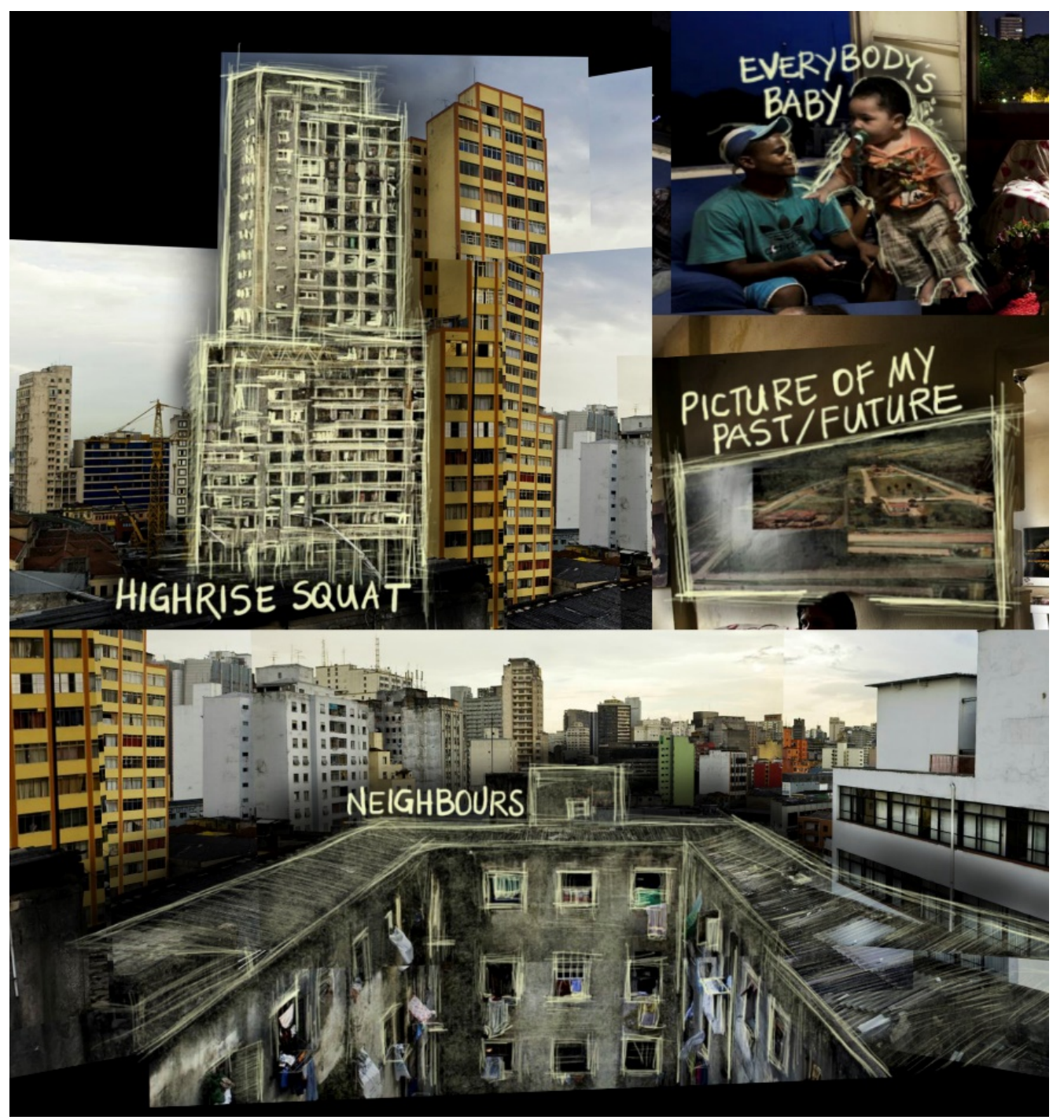

Fig. 7 - Nesta planta, estão reunidas as quatro imagens reticulares (1. Highrise Squat / 2. Everybody's baby / 3. Pictures of my past / future e 4. Neighbours) que acionam os quatro filmes dentro da habitação "São Paulo".

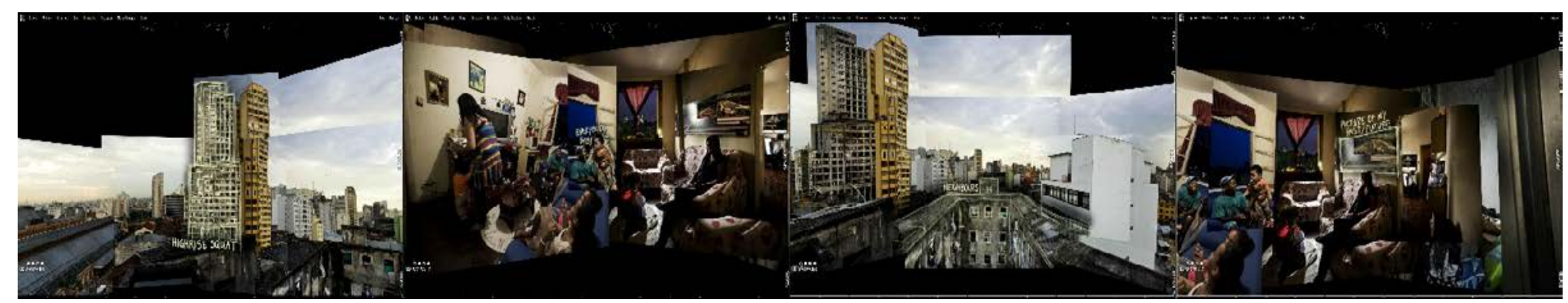

Fig. 8 - Os quatro ambientes da habitação São Paulo: Fora / Dentro / Fora / Dentro, construídos a partir da colagem de imagens manipuladas. Em cada um, há uma interação possível a partir do clique nas imagens reticulares. Cada ambiente, por sua vez, se relaciona ao outro em circularidade. Arrastando, horizontalmente, cada tela/ambiente - seja em direção à esquerda ou à direita - chegamos à próxima. "Dentro" e "fora" se confundem em uma atmosfera que busca reconstruir "the towers in the world, the world in the towers" (as torres no mundo e o mundo nas torres). 
A partir de imagens manipuladas, estamos em Toronto, Canadá, onde crianças em roda interagem com a música tibetana ao redor da câmera. 0 apartamento, de modo alegre, está contagiado. Nosso movimento em 360ำ $(\mathrm{em}$ tempo real durante a execução do filme na timeline) testemunha, embora de um ponto fixo, a circularidade da música, talvez inconcebível senão a partir de uma compreensão (e de um passeio aleatoriamente) circular. A câmera aqui adquire nova dimensão ontológica, uma constituição híbrida que, enquanto nos possibilita "rodar com a roda" (ou melhor, como na capoeira se diria: jogar com a roda), cria também novas condições de autoria. Quem é o diretor quando cabe ao próprio "navegador" a escolha de um ponto de vista (podendo estender essa pergunta à montagem)?

Embora pudéssemos argumentar que a questão da perspectiva parte sempre de uma relação subjetiva daquele que vê (e sente!), a tradição do plano fixo ${ }^{90}$ no cinema efetivamente contempla, a priori, uma perspectiva do diretor do filme (e uma métrica, ritmo, controle, etc, exercidos pelo montador). Aqui, instabilizando a margem do quadro, é como se Cizek convidasse-nos a participar dessa roda. Não à toa, parece-nos, a diretora escolhe realizar os registros com a câmera $360^{\circ}$, em três contextos musicais, em que, de algum modo, música e roda confundem-se, assim como conceito e técnica.

São manipuladas as imagens, ou melhor, imagens manipuladas à nossa disposição (que manipulamos), lembrando-nos do fato da insuficiência das imagens estáticas. São "centrifugacidades", que reforçam que toda escolha, todo enquadrar, pressupõe abdicar de algo. Aqui, uma possível reconciliação com o "real" baziniano, já que, mais do que a escolha deliberada do "recorte", estamos diante da possibilidade de "recortar" no instante em que a(s) câmera(s), multiperspectivista(s), captura(m) tudo, “[...] e que a decupagem é comandada então pelos aspectos dessa realidade". (BAZIN, 2014:94).

\footnotetext{
90 Compreendendo aqui enquanto plano fixo, os planos em que não há a possibilidade de troca de ponto de vista pelo navegador, o que abarca praticamente toda a tradição da linguagem cinematográfica. Portanto, ainda que o plano traga algum movimento (como, por exemplo, um plano sequência), na impossibilidade de explorarmos novas perspectivas, consideramos este plano enquanto "fixo".
} 


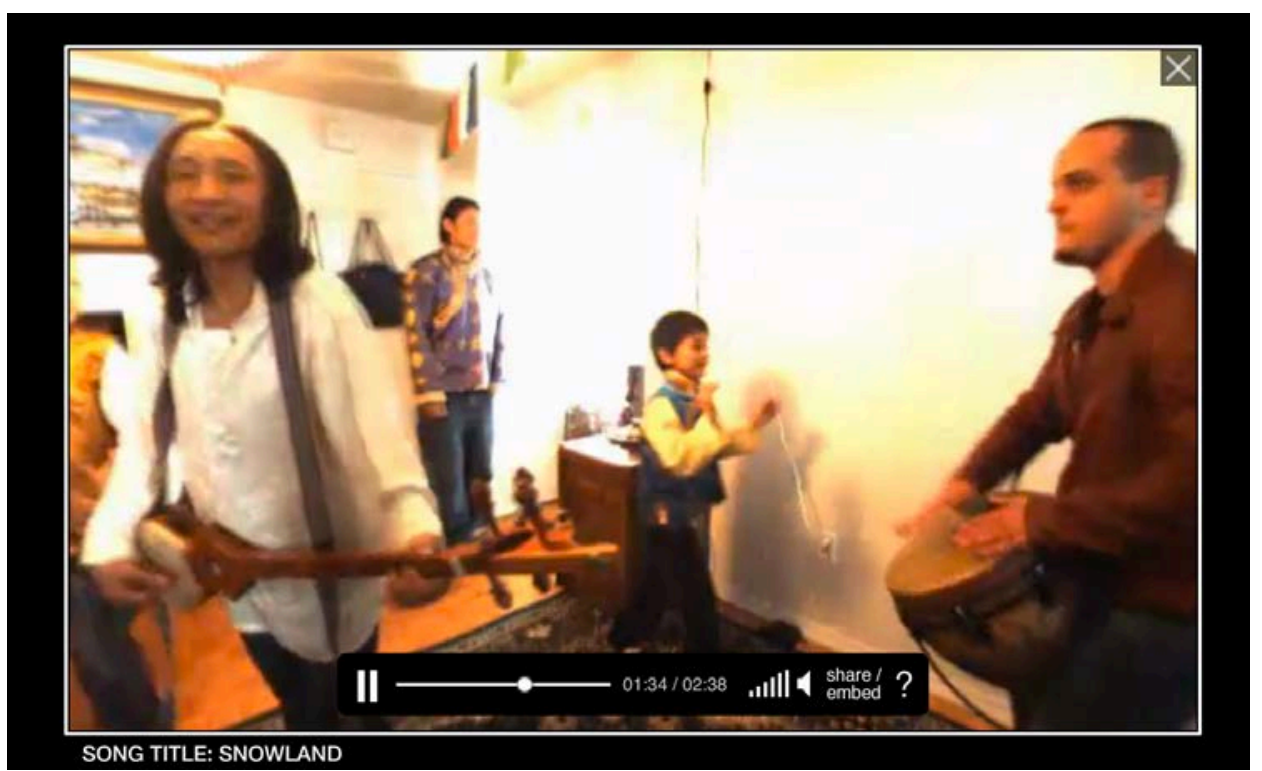

Fig. 10 - 0 filme $360^{\circ}$ permite que nos movimentemos junto com a roda que, por sua vez, movimentase em torno de nós/câmera.

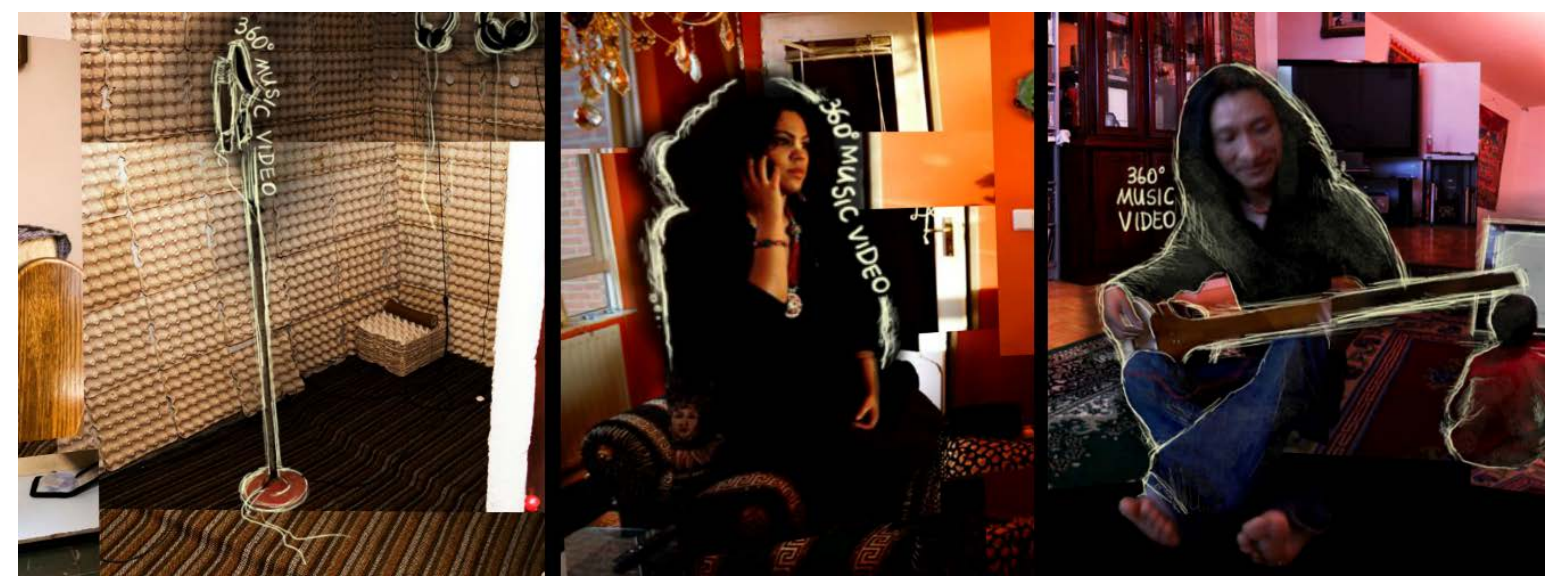

Fig. 11 Essa planta mostra as imagens reticulares que acionam os vídeos musicais 360oㅡ sucessivamente em Havana, Amsterdam e Toronto. Em Amsterdam e Toronto, as imagens são dos próprios protagonistas das habitações; em Havana, do microfone do estúdio.

\section{Janelas desmontadas: De fora da janela para a casa de vidro}

A obsessão pela montagem, comum a Vertov faz do mundo um puzzle de imagens tão só para reconstruir num novo conjunto mais exaltante. Desmontar para remontar. (Comolli apud BAIRON, 2008) ${ }^{91}$

Tal como pontua Gaudenzi (2013), Out My Window - e sua experiência de documentário em $360^{\circ}$ - é uma experiência tributária de uma estética e

${ }^{91}$ Cf. COMOLLI, Jean-Louis. O Futuro do Homem. 0 homem da câmera de filmar. in: 0 Olhar de Ulisses. 0 Homem e a Câmara. Cinemateca Portuguesa. 2001. pp. 47-67. 
metodologia largamente utilizadas pelo Cinema Verité $^{92}$. Ao passo que também nos parece pertinente apontar possíveis convergências com categorias e proposições ligadas à teoria da montagem eisensteiniana, bem como à lógica de criação de banco de dados fílmicos vertoviniana.

Experiências como a do documentário canadense chamam a atenção no tocante à sintaxe fílmica, para uma característica talvez pouco salientada na teoria da montagem: a compreensão de que aleatoriedade dos acontecimentos, em uma estrutura reticular, de múltiplos acionamentos, é semelhante à cotidianeidade da vida, em que, a partir de categorias previamente estipuladas, cabe ao sujeito jogar, desvendar, imiscuir, vivenciar, isto é, praticar sua linguagem.

É como se conceitualmente dialogássemos, de algum modo, com o projeto da Glass House ${ }^{93}$, idealizado pelo realizador soviético Sergei Eisenstein, no qual, a partir de uma compreensão expandida da montagem, subvertendo uma gramática fílmica mais rígida, seríamos capazes de observar a vida cotidiana através dos vidros (e espelhos?) de um edifício transparente.

Solução cenográfica que, por sua vez, a partir da simultaneidade de acontecimentos, constituiria uma metonímia - a casa desvelada - a esboçar a crítica visão do diretor a propósito do exacerbado individualismo estimulado pelo capitalismo. Bulgakowa (2005), nota que

The director confronts the spectators with all these views; now, cinematic space is not assembled as a montage space bridging the breaks and gaps. The experimental space is naturalised, acentric - with

\footnotetext{
92 Sobreutdo com ênfase em sua característica participativa/interativa que envolve, portanto, a inter-relação entre os realizadores e os sujeitos filmados.

${ }^{93}$ Em viagem à Berlin, em 1926, para a estreia de "Encouraçado Potemkin", Sergei Eisenstein principiou o projeto de uma audaciosa obra cinematográfica intitulada "Glass House". Segundo Bulgakowa (2005), Eisenstein teria visitado Fritz Lang em plena filmagem de "Metrópolis", o que teria lhe servido de inspiração a sua obra, assim como, dentre outras referências, a arquitetura transparente de Bruno Taut. Não obstante, a empreitada, cujo ideia fora a primeira apresentada por Eisenstein a Paramount - após ter assinado um contrato de produção -, não ter sido realizada, no âmbito teórico sua proposta é frequentemente lembrada por representar um pressuposto proto-interativo à especificidade cinematográfica, que subvertendo a misé-en-scene e, consequentemente, a narrativa, atribuiria à câmera o principal "papel" de conduzir a história, dotando-a, de modo evidente, de alguma "subjetividade". A propósito do Palácio de Cristal, de Bruno Taut, explorado a partir da hipermídia Bauen im licht Cf. BAIRON, Sérgio. op. cit. (2007).
} 
rotating figures, figures that are floating in space without the force of gravity. Windows, walls, ceilings, floors do not limit the image; the distinction between above and below, near and far, inside and outside are removed and the view is open. ${ }^{94}$ (Bulgakowa, 2005).

A partir dessa concepção, ao ampliar (e evidenciar!) de forma centrífuga ${ }^{95}$ o espaço cinematográfico, Eisenstein parece propor-nos uma espécie de "desmontagem" fílmica. Embora as categorias de montagem por ele sugeridas (métrica, rítmica, tonal e atonal), assim como o estágio máximo da montagem intelectual, constituíssem, stricto sensu, uma prerrogativa para se pensar e conceber o filme à luz da duração de seus planos, do ritmo dentro dos "quadros", da tonalidade de "sons" harmônicos e fisiológicos, de uma percepção ampliada, de uma base ideogramática de linguagem, etc., sugerindo assim um controle bastante preciso da montagem, o esboço da Glass House propõe, com base em sua própria virtualidade ${ }^{96}$, uma estrutura "desmontada", aberta, cabendo ao espectador/câmera estabelecer, em sua experiência, seu próprio percurso (centrífugo) de montagem. A essa característica dinâmica, (im)permanente e labiríntica no projeto do filme, acrescenta Bulgakowa (2005) que

The first version of script (1926-7) unfolds a drawn storyboard of an experimental abstract movie, with the mobile camera and an elevator serving as the protagonists: the elevator moves between planes, floors and ceilings, modifying the view of the observer (i.e., the camera). The camera alone is capable of seeing this building, with its blind inhabitants. The transparency of the structure, the change and changeability of viewpoints, creates the basic principle of visual dramaturgy, which becomes the narrative structure. Eisenstein defined it as

\footnotetext{
94 Tradução nossa: "O diretor confronta os espectadores com todos esses pontos de vista; agora, o espaço cinematográfico não é combinado como um espaço de montagem fazendo a ponte entre as lacunas e intervalos. 0 espaço experimental é naturalizado, descentrado - com figuras rotativas, flutuando no espaço -, sem a força da gravidade. Janelas, paredes, tetos e chão não limitam a imagem; a distinção entre acima e abaixo, perto e longe, dentro e fora são removidos e a visão é aberta."

95 À noção centrífuga do quadro cinematográfico, Bazin (2014), diferencia o que compreende como uma relação centrípeta do quadro da pintura. Para o autor, o quadro da imagem cinematográfica pode ampliar-se ao infinito, constituindo - o enquadramento da objetiva - apenas enquanto recorte da realidade. Já a pintura "polariza o espaço em direção seu interior".

${ }^{96}$ Compreendendo aqui o "virtual ", em sua acepção próxima à potência (virtus), portanto "em potencial”. Cf. LÉVY, Pierre. O que é o virtual? São Paulo: Editora 34, 1996.
} 
a comedy of situations that are treated literally as various positions of the camera and its constantly changing points of view. ${ }^{97}$ (BULGAKOWA, 2005).

Contemporaneamente à efusiva experiência cinematográfica que consistia o projeto Glass House, o diretor soviético pensou e propôs a criação de um "livro esférico", uma proposta de diálogo com uma circularidade do pensamento, uma vez que compreendia a insuficiência do livro, em seu formato códice, como um processo/margem a ser superado. 0 códice, por excelência, como uma espécie de músculo atrofiado, relegou ao pensamento verbal um reinado da linearidade no Ocidente, sempre com o movimento da esquerda para direita, de cima para baixo, consistindo, desse modo, no pilar fundamental da metodologia científica. Bulgakowa (2005) salienta ainda que o projeto do livro esférico de Eisenstein configuraria uma resposta radical à fragmentação do pensamento científico, separado em (estanques) campos e áreas de conhecimento. Em um ambiente esférico, não encontraríamos problemas em pensar (ou iríamos ao encontro de) um habitar fragmentado e dispersivo para a compreensão, uma característica bastante condenada pela ciência moderna. Como refletia Eisenstein, a bidimensionalidade do livro (em seu formato códice) implicaria abnegar, dentre outras possibilidades, a uma percepção sistemática da simultaneidade.

It is very hard to write a book. Because each book is twodimensional. I wanted this book to be characterised by a feature that does not fit under any circumstances into the two-dimensionality of a printing element. This demand has two aspects. First, it supposes that the bundle of these essays is not to be regarded successively. In any case, I wish that one could perceive them all at the same time, simultaneously, because they finally represent a set of sectors, which are arranged around a general, determining viewpoint, aligned to different areas. On the

\footnotetext{
97 Tradução nossa: "A primeira versão do roteiro (1926-7) revela o desenho de um storyboard de um filme abstrato experimental, com uma câmera móvel e um elevador que servem como protagonistas: o elevador se move entre os planos, pisos e tetos, modificando o ponto de vista do observador (ou seja, a câmera). A câmera é a única capaz de ver neste edifício, com os seus habitantes cegos. A transparência da estrutura, a alteração e mutabilidade de pontos de vista, cria o princípio básico da dramaturgia visual, que vem a ser a estrutura narrativa. Eisenstein definiu-a como uma comédia de situações que é tratada literalmente com várias posições da câmara e seus pontos de vista em constante mudança." (Bulgakowa, 2005). Mais à frente no texto, a autora diz que Eisenstein referia-se ao projeto como "uma comédia do e para o olho" e, por fim, a versão final do roteiro dessa "comédia do olho" fora substituída por uma tragédia de dois sonhadores utópicos.
} 
other hand, I want to create a spatial form that would make it possible to step from each contribution directly into another and to make apparent their interconnection... Such a synchronic manner of circulation and mutual penetration of the essays can be carried out only in the form (...) of a sphere. But unfortunately, books are not written as spheres ... I can only hope that they will be read according to the method of mutual reversibility, a spherical method - in expectation that we will learn to write books like rotating balls. Now we have only books like soap-bubbles. Particularly on art." (Eisenstein apud BULGAKOWA, 2005). ${ }^{98}$

Assim como o conceito de Glass House (em sua "desgramatização") sugeriria uma espécie de "desmontagem fílmica", o esboço do (que seria o) livro esférico de Eisenstein, em texto de 1929, proporia uma deslinearização - ainda que textual -, ou uma "esferalização" do pensamento, antevendo, de algum modo, o próprio conceito de hipertexto. Algo que, no âmbito digital, somente pôde ser melhor desenvolvido (enquanto pressuposto teórico-tecnológico) a partir de hipermídias em que pese, de acordo com Bairon (2006, p.84) que

A experiência na interatividade deve apresentar uma pertença de sentido que não está somente relacionada a um aspecto particular, mas adota e transmite um conjunto de sentidos que se apresenta diante da navegação. 0 que é proporcional a dizer que toda experiência estética é uma experiência inacabada e, sobretudo, inacabável com o sentido, ainda que teórico.

${ }^{98}$ Cf. Sergej Eisenstein. Drei Utopien - Architekturentwurfe zur Filmtheorie, pp. 31-32. Tradução nossa: "É muito difícil escrever um livro. Porque que cada livro é bidimensional. Eu gostaria que este livro pudesse ser caracterizado por um traço que não se encaixasse em nenhuma circunstância na bidimensionalidade de um elemento de impressão. Essa demanda tem dois aspectos. Primeiro, supõe que o fascículo destes ensaios não é para ser considerado sucessivamente. Em todo caso, eu gostaria que se pudesse percebê-los todos ao mesmo tempo, simultaneamente, porque, finalmente, representam um conjunto de setores que são organizados em torno de um geral, determinante ponto de vista, alinhado às diferentes áreas. Por outro lado, quero criar uma forma espacial que tornaria possível passar de uma contribuição diretamente a uma outra e tornar visível a sua interconexão... Essa forma sincrônica de circulação e penetração recíproca dos ensaios pode ser realizada apenas na forma (...) de uma esfera. Mas, infelizmente, os livros não são escritos como esferas... Só posso ter esperança de que eles serão lidos de acordo com o método de reversibilidade mútuo, um método esférico - na expectativa de que vamos aprender a escrever livros como bolas giratórias. Agora temos apenas livros como bolhas de sabão. Particularmente na arte." 
Nesta compreensão, os sentidos construídos pela navegação e, consequentemente, pela interatividade, constituem propriamente um processo de montagem, portanto, de pertença. É como se estivéssemos montando Glass House, bem como o livro esférico, no exato momento de nossa interação/leitura. É como se, de algum modo, repetíssemos a cine-montagem inaugural de Vertov, em $O$ homem com a câmera (1929), em que

A condição à toda criação de sentido está vinculada à renúncia de qualquer condição constituída de linearidade narrativa. A falta constitutiva que se manifesta neste conjunto de rupturas é o que faz daquele que está navegando co-editor da montagem. (BAIRON, 2008). ${ }^{99}$

Embora Eisenstein e Vertov divergissem de modo bastante marcante a propósito de suas concepções cinematográficas, no âmbito de uma metodologia fílmica visando à formação de banco de dados, sobre a qual versa tanto a Glass House, de Eisenstein, quanto “0 homem com a câmera” (1929), de Vertov, é possível encontrarmos importantes correlações. Bairon (2008) a propósito do sistema de programação presente na metodologia de Vertov - em especial no filme citado -, salienta que a própria concepção de um banco de dados age como uma espécie de "protagonista" do filme. Algo que enseja a reflexão de que a montagem é "[...]a presença mais representativa do superlativo hipermidiático que nos traz este tipo de conceito cinematográfico. Sobreposição de montagens" (ibid, 2008).

O banco de dados, em "O homem com a câmera", é a expressão superlativa do cotidiano, que somente pode ser conjugada à luz da montagem, da sensibilidade e do filtro do cine-olho. Por sua vez, a transparência da Glass House, convidando ao jogo da câmera-sujeito dinâmica (aqui, também dotada de uma potencial função "decifradora", como em Vertov), enseja a reflexão sobre o alémmargem fílmico, na insuficiência do ser diante da linguagem e, ao mesmo tempo, da câmera diante da montagem, enquanto dispositivos em incessante acionamento dos diferentes ângulos, tomadas, caminhos (e pressupostos) dentro

\footnotetext{
${ }^{99}$ Algo que, em Out My Window, torna-se possível por seus mecanismos que buscam ampliar o quadro cinematográfico, convidando o interator a passear (em exercício de montagem,) por dentro/fora de seu entorno.
} 
do prédio de vidro, assim como na vida cotidiana de uma cidade em plena efervescência (ou de cidades e habitações, como em Out My Window).

Bulgakowa (2005) lembra que "the space of Eisenstein's Glass House is non-hierarchical; distance and the sensation of time are abolished"100. A ausência de um espaço efetivamente hierárquico no projeto de Eisenstein afirma, pelo contrário, uma comunicação heterárquica, portanto reticular e multiperspectivista 101, ensejando um diálogo ainda que introdutório com o pensamento hipermidiático para o qual, "compreender é entender-se na comunicação heterárquica" (Bairon \& Petry, 2000). No entanto, como assinala Bulgakowa (2005)

Narrative is a linear construction that could not be brought together with the materialised multi-layeredness of the visual space. Only hypertext would be an appropriate form for this; such a text would reconfigure the reader, forcing him to follow the cross connections. From this point on, Eisenstein starts to write his texts as hypertexts, thus making them extremely difficult to publish. ${ }^{102}$. (BULGAKOWA, 2005)

Embora prementes, as pretensões de Eisenstein não puderam ser efetivamente concretizadas, já que, à sua época, não haveria à disposição recursos para um pleno enfrentamento da hegemonia da linearidade.

\section{Descortinando}

As soluções em 360ำ exploradas em Out My Window permitem-nos alargar ainda mais o título do projeto. De que "janela" falamos, quando consideramos as "janelas de fora" (ou do que está "de fora", além da "minha" janela)? Poderíamos, do ponto de vista técnico, referirmo-nos à janela da tela

\footnotetext{
100 Tradução nossa: "o espaço na Casa de Vidro de Eisenstein é não hierárquico: distância e a sensação do tempo são abolidas".

${ }^{101}$ A propósito de uma interessante leitura que relaciona o cinema Eisensteiniano e o perspectivismo ameríndio Cf. Gonçalves, Marco Antônio. Sensorial throught: Cinema, perspective and Anthropology. Vibrant. V9, n.2. p. 160-183.

102 Tradução nossa: "A narrativa é uma construção linear, que não poderia conduzir, juntas, as multicamadas materializadas do espaço visual. Apenas o hipertexto poderia ser uma forma adequada para tanto; tal texto reconfiguraria o leitor, forçando-o a seguir as ligações cruzadas. Deste ponto em diante, Eisenstein começa a escrever seus textos como hipertextos, tornando-os extremamente difíceis de publicar."
} 
cinematográfica - em sua acepção na língua portuguesa ${ }^{103}$ - já que, em todo o espaço fílmico, há uma profusão de diferentes (e exteriores) "janelas"? Poderíamos também referir-nos à "janela" como expressão maior da reticularidade da vida, condição imprescindível do cotidiano? Em uma compreensão filosófica que vislumbra que toda janela é o pressuposto da abertura de uma nova, sucessivamente, ad infinitum. Portanto, "dentro" e "fora" (inside e outside) são, assim, planos indistintos de um mesmo locus. Out My Window atua como um jogo, ou melhor, como a condição de jogar, sob a qual não temos plenamente o domínio, mas que, enquanto o modo de ser da linguagem, somos jogados.

Em uma caminho bastante profícuo, compreendemos que filmes interativos (hipermídias fílmicas), com amplo desenvolvimento em reticularidade, como é o caso de Out My Window, ampliam discussões outrora ainda incipientes - embora encaradas com plenitude conceitual - (como exposto) para dois dos mais propositivos pensadores cinemáticos - Eisenstein e Vertov. Todavia, no âmbito do documentário participativo (Nichols, 2012) metodologia largamente explorada pelo Cinema Verité -, Out My Window também constrói uma interlocução sui generis, pois, se para o documentário participativo, “[...] o que vemos é o que podemos ver apenas quando a câmera, ou o cineasta, está lá em nosso lugar" (ibid, p.155), mostrando "a verdade de uma forma de interação", a interação aqui metamorfoseia-se em interatividade, entre o cineasta, os sujeitos fílmicos/filmados e nós, ampliando essa forma de negociação, pois somos nós, também os montadores do filme, que lá estamos (em todas as habitações) a abrir e descortinar novas janelas.

Por fim, aludindo ao poema "Acompanhando Max Bense em sua visita à Brasília”, de 1961, de João Cabral de Melo Neto, quando escreve propósito da visita do filósofo Max Bense à cidade de Brasília, seria também possível dizermos sobre Out My Window: “[...] eu também de visita ia: ao edifício do que

\footnotetext{
${ }^{103}$ Em termos técnicos, compreende-se a janela do filme por sua proporção horizontal $\mathrm{x}$ vertical, ou seja, o espaço ocupado pela tela (por exemplo 1.77:1, 1.33:1, 2.35:1, etc). Em inglês utiliza-se a noção de aspect ratio.
} 
ele dizia: edifício que, todavia, de duas formas existia: na de edifício em que se habita e de edifício que nos habita"104. (Bense, 2009)

\section{Reticularidades Guarani}

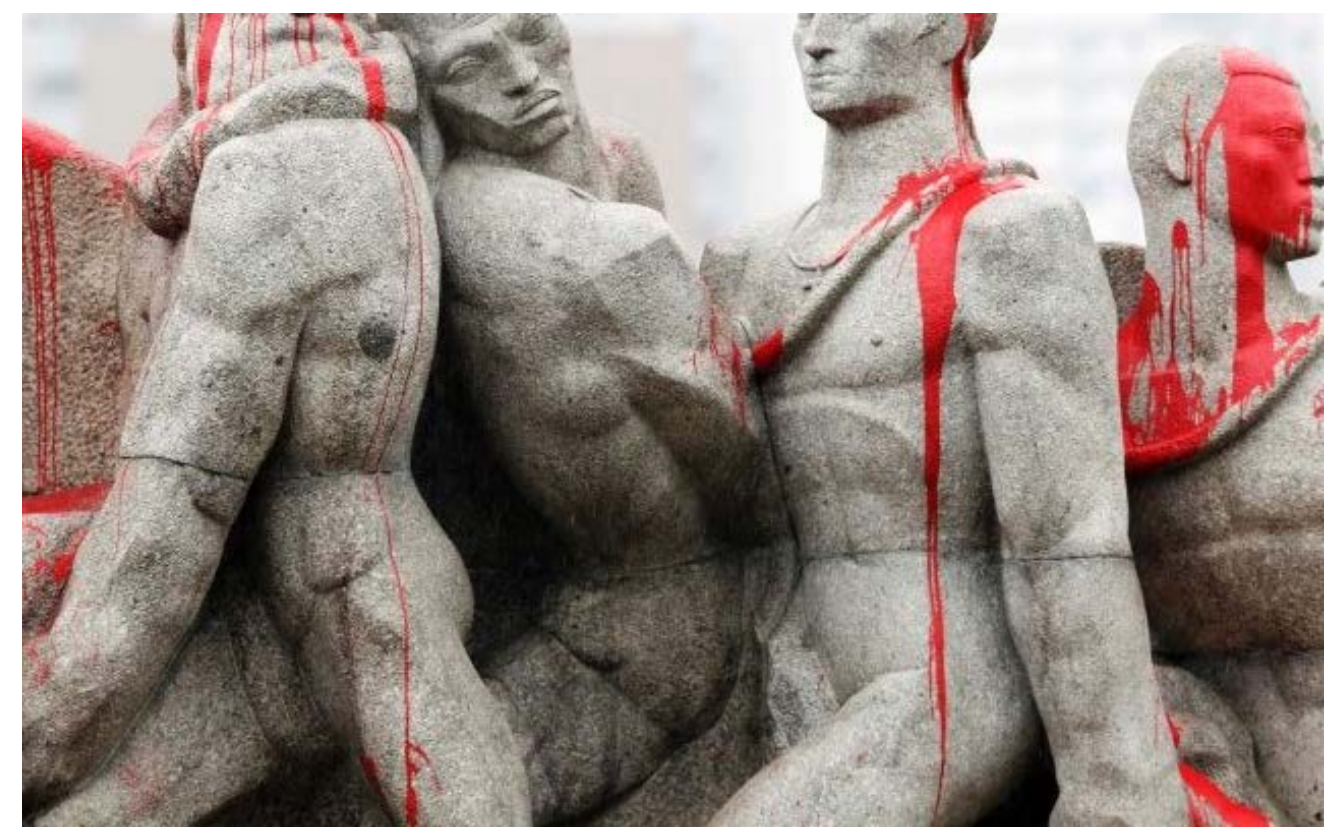

fig. 11 - "Monumento às bandeiras", de Victor Brecheret, tingido de tinta vermelha em intervenção guarani.

Vão dali, próximos ao pântano, da árvore apodrecida. Vão dali, empunhando armas.

Vão dali sangrando a terra, derrubando a estrutura que segura.

Quem segura os alicerces do céu?

(Se) Vão daqui, como uma pintura gasta, velha, cada vez mais, translúcida,

(Se) vão os índios.

Vãs filosofias frente aos dentes do ocidente, vão-se frente ao progresso que os extirpa, que tira as cores de suas tintas.

Vagarosamente vão anunciando que aqueles que vem dali, São os verdadeiros vândalos.

104 Grifo nosso. 


\section{"Deixou de ser pedra e sangrou"}

Reticularidades cotidianas: inadvertidamente lemos a notícia, em 2013, de que o "Monumento às bandeiras", paquidérmica escultura de Victor Brecheret, sofrera uma intervenção por parte dos guarani-mbya, moradores da capital de São Paulo. Em procissão desde a Avenida Paulista - metonímia do progresso econômico do país - os guarani-mbya chegam em frente ao parque do Ibirapuera $^{105}$, onde se situa a estátua. De lá, ressignificando-a fazem sangrar, jogando tinta vermelha sobre os rostos e corpos de pedra de seus algozes:

Ela deixou de ser pedra e sangrou. Deixou de ser um monumento em homenagem aos genocidas que dizimaram nosso povo e transformou-se em um monumento à nossa resistência. Ocupado por nossos guerreiros xondaro, por nossas mulheres e crianças, esse novo monumento tornou viva a bonita e sofrida história de nosso povo, dando um grito a todos que queiram ouvir: que cesse de uma vez por todas o derramamento de sangue indígena no país! (TUPÃ, 2013) ${ }^{106}$

Nesta mesma terra deste chão (terra e chão seriam aqui sinônimos?), que fora algum dia um locus para as almas ameríndias, a normativa imprensa assegura de que o monumento em homenagem aos bandeirantes, patriarcas colonizadores, sofrera "vandalismo".

Os filhos bandeirantes desta "pátria mãe gentil", plugados em seus dispositivos móveis, são bombardeados por reticularidades noticiosas que dão o veredicto: A estátua, "pobre coitada", sofrera vandalismo. Os jornalistas apressam-se em perguntar aos transeuntes que, pegos de surpresa, se põe a condenar àqueles que "vandalizam" as artes, àqueles que "enfeiam" a cidade e os monumentos oficiais, da história oficial. "Mereceriam estar na cadeia!”, dizem. Os guarani-mbya e sua Comissão Yvirupá, como em uma autêntica media jiu-jitsu (SHOHAT; STAM, 2006), ou poderíamos dizer, nos seus termos, uma "media xondaro", contra-atacam a hegemonia midiática-bandeirante, contrapõe a sua

105 Do tupi ypi-ra-ouêra, que siginifca árvore apodrecida. 0 parque ocupa uma região alagadiça, que pertencia a um antigo aldeamento indígena.

106 Disponível em: http://www.revistaforum.com.br/2013/10/05/monumento-asbandeiras-homenageia-genocidas-que-dizimaram-nosso-povo-diz-lideranca-indigena/. Acesso em: 04/04/2014. 
força e, a partir do audiovisual, em reticularidade, explicam o passado e resistem para o futuro ou, como diria magistralmente Daniel Munduruku107 (informação verbal), "re-existem" para o futuro. Configuram coletivamente, assim, modos de re-existência.

É pertinente observamos que a partir do ano de 2012, em especial, os guarani-mbya habitantes da cidade de São Paulo lançaram-se em uma contra ofensiva, articulando diversas ações a fim de pressionar a opinião pública e autoridades competentes a se posicionarem favoravelmente quanto as emissões de Portarias Declaratórias, para o referendamento da ampliação da demarcação de suas Terras Indígenas ${ }^{108}$. Todas as conquistas dos guarani-mbya no ano de 2015 e 2016, foram o resultado de uma ampla mobilização que explorou dois tipos de "ocupação". A primeira, de forma tradicional, constituiu a ocupação de espaços públicos como órgãos federais, estradas, avenidas, etc, a fim de

107 Em palestra proferida no contexto do encontro Mekukradjá no Itaú Cultural em 29/09/2016.

${ }^{108}$ Em 19 de Abril de 2012, a presidência da Funai (Fundação Nacional do Índio), publica no Diário Oficial da União seu relatório em que recomenda a ampliação da "Terra Indígena Tenondé Porã", no extremo sul de São Paulo, passando de 26 ha para 15.969 ha. Já em 30 de abril de 2013, a Funai publica no Diário Oficial da União um outro relatório em que recomenda a ampliação da "Terra Indígena Jaraguá" - até então a menor Terra Indígena em extensão do país -, na zona norte da cidade, passando de 1,7 ha para 532 ha. Ambas publicações dizem respeito à demandas iniciadas e cobradas pelos guarani desde a década de 1980. Após a publicação dos relatórios por parte da Funai, os guarani iniciam uma série de protestos e mobilizações a fim de garantir as assinaturas das Portarias Declaratórias pelo Ministério da Justiça. Depois dos guarani exercerem diversas formas de pressão, no dia 29 de maio de 2015 o então Ministro da Justiça, José Eduardo Cardozo, assina a portaria declaratória para a ampliação da "Terra Indígena Jaraguá", seguindo para homologação presidencial. Em 5 de maio de 2016, após contínua pressão dos guarani, que chegam a ocupar o escritório da presidência da República em São Paulo, o Ministro da Justiça Eugênio Aragão assina a portaria declaratória ampliando a "Terra Indígena Tenondé Porã”, que segue para homologação presidencial. 0 Diário Oficial da União, de 19 de Abril de 2012, com o relatório da Funai favorável à ampliação da "Terra Indígena Tenondé Porã" está disponível em: http://pesquisa.in.gov.br/imprensa/jsp/visualiza/index.jsp?data=19/04/2012\&jornal= 1\&pagina=18\&totalArquivos=104 . O Diário Oficial da União de 30 de Abril de 2013, com o relatório da Funai favorável à ampliação da "Terra Indígena Jaraguá", está disponível

em: http://pesquisa.in.gov.br/imprensa/isp/visualiza/index.jsp?data=30/04/2013\&jornal= 1 \&pagina $=52$ \&totalArquivos $=112$. Acesso em 05/03/2016. Para uma problematização dos processos políticos e jurídicos que envolveram a demarcação dos territórios em São Paulo e a estratégia de organização dos guarani-mbya, Cf. FARIA, Camila Salles de. A luta Guarani pela terra na metrópole paulistana: contradições entre a propriedade privada capitalista e a apropriação indígena. Tese (Doutorado) - Faculdade de Filosofia, Letras e Ciências Humanas da Universidade de São Paulo. Departamento de Geografia. São Paulo, 2015. 
reivindicar a atenção da opinião pública às suas pautas. A segunda ocupação é o que aqui compreendemos como uma "ocupação digital-reticular", que baseou-se em uma articulação frequente a partir de redes sociais e ambiências interativas, como o facebook e youtube. A série de vídeos em reticularidade faz parte, portanto, deste conjunto de ações digital-reticulares.

\section{EIXO A - Rodovia Rojoko - O dia em que fechamos a Bandeirantes}

A partir do acesso à pagina de youtube do filme "Rodovia Rojoko - 0 dia em que fechamos a Bandeirantes - CGY"109, o processo reticular inicia-se no que denominamos eixo $\mathrm{A}$, com o cacarejo de um galo, que nos remete às previsões da rezadora guarani-kaiowá, relatadas por Danowski e Viveiros de Castro (2014)110, sobre os diversos sinais do fim dos tempos, dentre eles o fato de que "os galos haviam se posto a cantar sistematicamente fora de hora".

Algo sugere que o cacarejo do galo, a funcionar enquanto signo do "desajuste", anuncie em um âmbito a inevitável derrocada, em outro, no entanto, desperte os guarani para a luta. Em um movimento rítmico, o galo sai de quadro e um letreiro-manifesto anuncia:

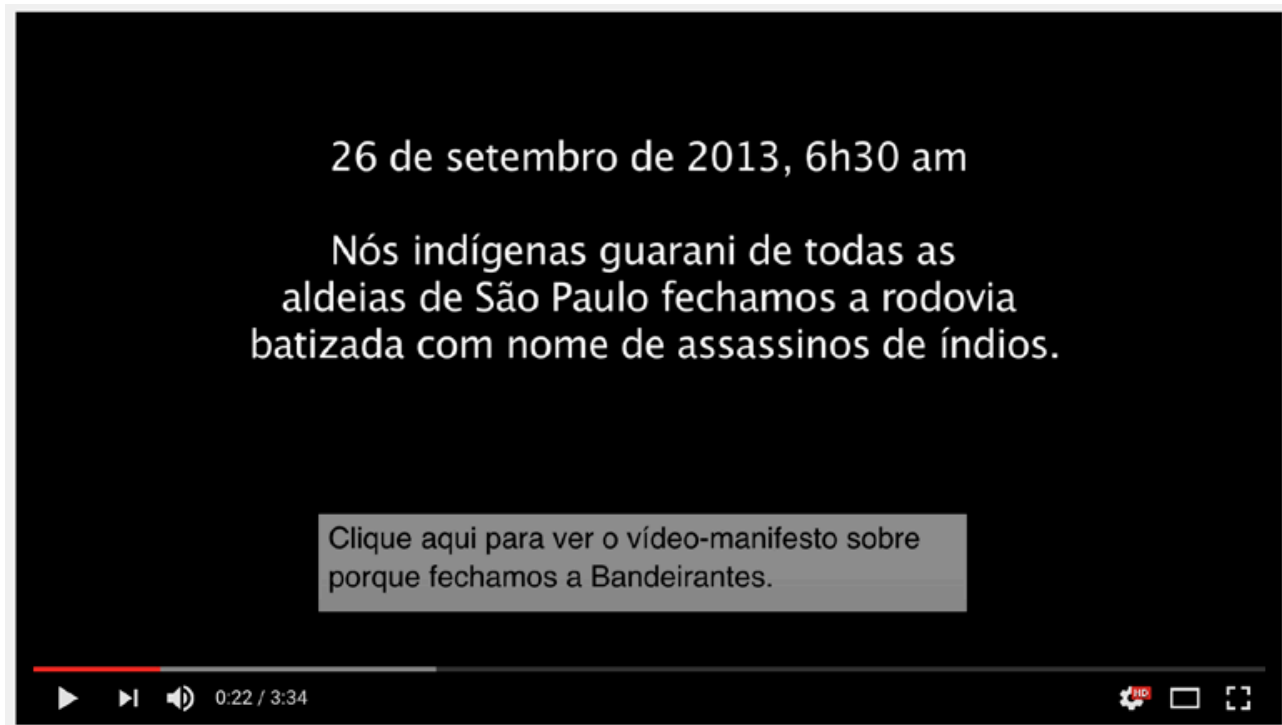

fig. 12 - "26 de setembro de 2013, 6h30 am. Nós indígenas guarani de todas as aldeias de São Paulo fechamos a rodovia batizada com o nome de assassinos de índios."

109 Disponível em: https://www.youtube.com/watch?v=JCBOU4wQmR8 . Acesso em: 04/04/2014.

110 Cf. DANOWSKI, Débora, CASTRO, Eduardo Viveiros de. Há mundo por vir? Ensaios sobre os medos e os fins. Desterro (Florianópolis): Cultura e Barbárie: Instituto Socioambiental. 2014. 
Ao mesmo tempo, a possibilidade reticular se apresenta, logo aos 17 segundos, a partir do nodal "Clique aqui para ver o vídeo-manifesto sobre porque fechamos a Bandeirantes". Podemos optar por um caminho que nos prepara para a "luta" ou, como advoga a outra possibilidade, conhecermos os motivos que fundamentam a mesma. São duas, aqui, as camadas sobrepostas, cuja justaposição caberá ao interator escolher. Se persistirmos no primeiro caminho, após o letreiro-manifesto, somos levados à manifestação na rodovia, locus aqui da reocupação, re-existência, guarani- mbya.

Em um grande plano geral, avistamos uma enorme roda onde os guarani, de mãos dadas, cantam e dançam, enquanto uma fogueira arde e cria uma simbólica cortina de fumaça que torna opaca a visão dos guarani para os brancos do lado de lá, que em seus carros aguardam o término do protesto, e vice-versa. É como se esta cortina de fumaça, embora fugaz, alardeasse: Há uma barreira entre nós; entre aqueles que são atravessados pela mesma rodovia e que é, para uns, signo do progresso e do futuro, para outros um atestado permanente da crueldade colonizadora do passado e do presente. Fumaça esta que, em sua quase transparência, separa o indígena e o não-indígena, o mundo do "capital" e o do "povo da borda".

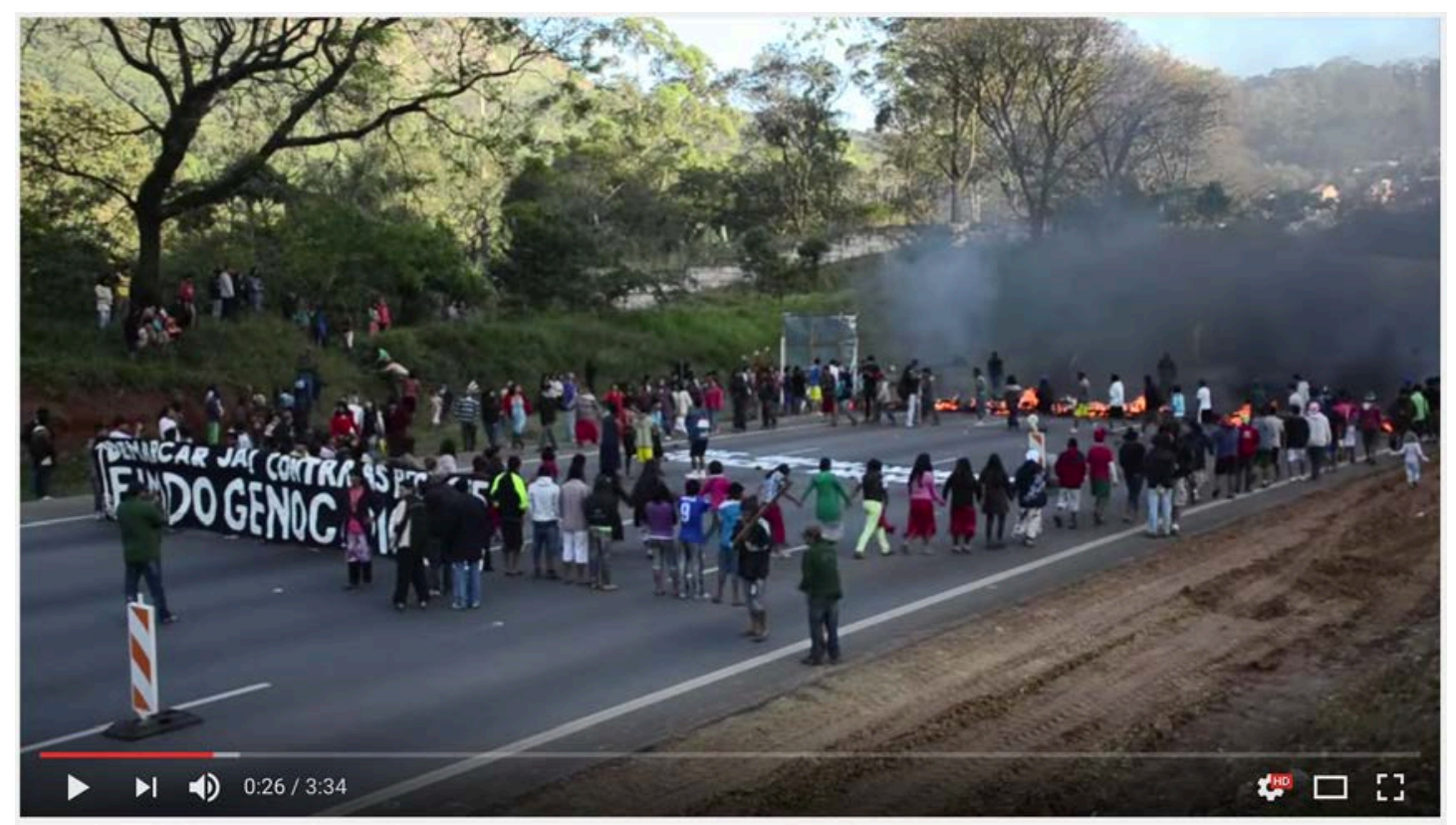

fig. 13 - Avistamos uma enorme roda onde os guarani, de mãos dadas, cantam e dançam, enquanto uma fogueira arde e cria uma simbólica cortina de fumaça que torna opaca a visão dos guarani para os brancos do lado de lá e vice-versa. 
Bordunas e faixas que clamam pelo fim do genocídio dos povos indígenas também são empunhadas. Após alguns cortes, notamos também uma grande faixa estendida no chão da rodovia - que cruza terras guarani e homenageia, no nome, os seus algozes -: “GUARANI RESISTE DEMARCAÇÃO JÁ!”.

Como quem anuncia aos céus, a faixa, que só pode ser vista de cima, é um claro recado tanto aos brancos e sua política excludente (que poderiam visualizála a partir de helicópteros com as imagens transmitidas pelas emissoras de televisão) quanto, poderíamos inferir, ao cosmos.

As faixas seguradas pelos guarani afirmam-se também contrárias às PEC 215 e 237, bem como ao projeto de lei $227^{111}$ que, em ampla escala, propõe uma

111 As PEC (Proposta de Emenda à Constituição) 215 e 237 e o Projeto de Lei 227 propõem, em bases gerais, redefinições a propósito do uso e das demarcações dos territórios tradicionais indígenas. A PEC 215, aprovada no ano de 2015 pela "Comissão Especial da Demarcação de Terras Indígenas da Câmara" dos deputados (em uma primeira instância), propõe (assim como a PEC 38/1999) transferir a decisão sobre a demarcação de terras indígenas, territórios quilombolas e unidades de conservação do Poder Executivo para o Poder Legislativo, além de modificar o sistema indenizatório sobre as áreas demarcadas. A PEC 237 "permite que produtores rurais, por meio de concessões, tomem posse das terras indígenas, dessa forma, possibilitando a abertura dessas áreas ao agronegócio" (ROSA, 2014, p.6), e o PLP 227 "pretende legalizar a existências de latifúndios, assentamentos rurais, estradas, mineração, empreendimentos econômicos dentre outros, em áreas indígenas" (op. cit). Decorre disso a reflexão de que o poder legislativo é historicamente dominado por bancadas que representam setores hegemônicos da sociedade brasileira, com amplo lastro na economia - tais quais os segmentos políticos ligados ao agronegócio -, assim como os segmentos políticoreligiosos com grande representatividade e, consequentemente, uma agenda que procura atender diretamente seus interesses mais próximos (ambos os casos compreendem as chamadas "bancada ruralista" e "bancada evangélica"). No preâmbulo destes projetos há também a recorrente tentativa de se aprovar a chamada tese do "marco temporal", segundo a qual as "terras" indígenas (para uma distinção dos conceitos de "terra" e "território", Cf. GALLOIS, 2004) seriam apenas aquelas ocupadas por indígenas quando se deu a promulgação da Constituição de 1988. As associações ligadas aos direitos indígenas (Como a APIB - Articulação dos Povos Indígenas do Brasil, o Instituto Socioambiental, entre outros), bem como pesquisadores sobretudo nas áreas da antropologia e do direito, vêm sistematicamente alertando para os perigos que representam essas medidas no âmbito político-jurídico, que privilegiarão vorazmente os setores hegemônicos e acirrarão ainda mais a violência no campo, em detrimento das populações historicamente fragilizadas no processo colonialista, alvos de constantes investidas. Para uma maior problematização Cf: GALLOIS, Dominique Tilkin. Terras ocupadas? Territórios? Territorialidades? In: RICARDO, Fany (org.) Terras Indígenas e Unidades de Conservação da Natureza: o desafio das sobreposições. São Paulo: Instituto Socioambiental, 2004, p. 37-41. e ROSA, Marilse. 0 ativismo político indígena no Brasil pós-1988 e os desafios à garantia dos seus direitos. $8^{\circ}$ Encontro da ANDHEP - Políticas Públicas para a Segurança Pública e Direitos Humanos. Faculdade de Direito USP. São Paulo, 2014. Também a propósito de questões que tangenciam estes assuntos e focam na dimensão político institucional da causa indígena, são de absoluta 
retirada de direitos históricos das populações indígenas brasileiras. Aos um minuto e treze segundos, em um outro grande plano geral é possível notar, quase desapercebidamente que, no segundo plano por trás de uma linha de frente composta por homens guarani, um funcionário da rodovia parece, com seu celular, filmar a manifestação.

Após sete segundos, curiosamente, o contra-plano da mesma cena sugere evidenciar a perspectiva oposta, qual seja, a posição / ponto de vista próximo a deste funcionário (sem que o visualizemos). Estaria este olhar guarani propondo, a partir da montagem, um câmbio de perspectiva em uma afirmação da alteridade presente no olhar? Evidenciando, ao acaso, o fato de que enquanto filmam são também são filmados? Ou de que enquanto festejam e manifestam-se, são também notados?

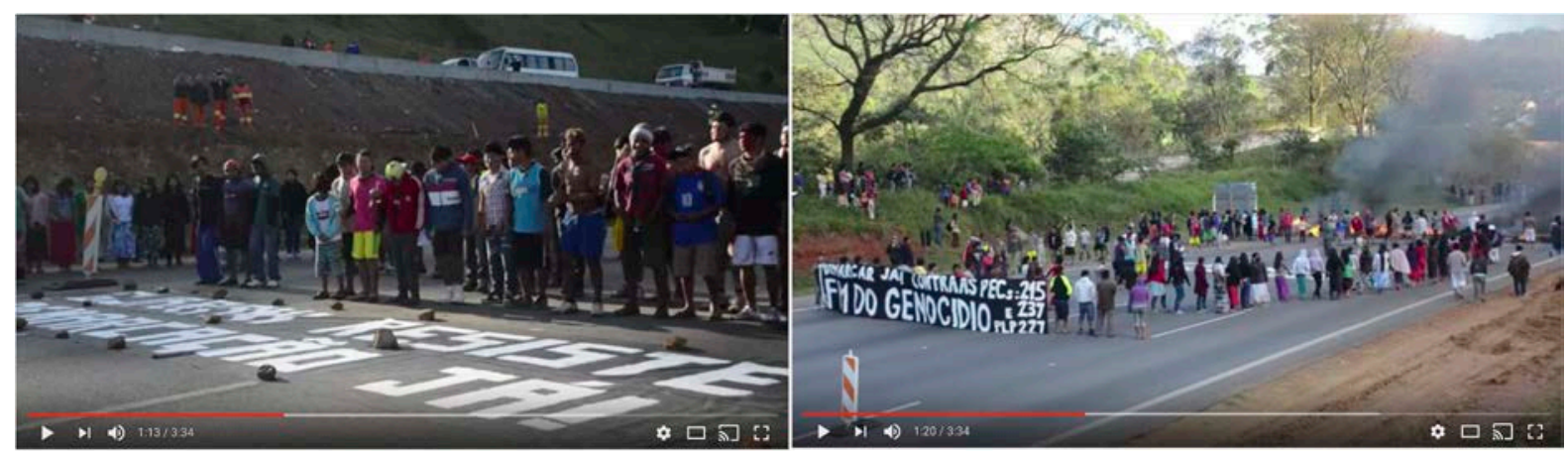

fig. 14 - Plano e contra-plano, próximo à manifestação e distante dela.

De modo geral, o filme apresenta-se em moldes semelhantes a um videoclipe (característica acentuada sobretudo pela canção guarani que acompanha toda a narrativa audiovisual), aspecto que o aproxima de uma linguagem amplamente explorada pelas novas medias e, ao mesmo tempo, circunscreve-o a uma dinâmica ritual inerente, onde a música e o canto tem um valor profundo para às manifestações de cunho político e espiritual dos guaranimbya $^{112}$.

Sua montagem, não obstante, evidencia frequentemente tomadas nos moldes do cinema direto observativo e, por vezes, embora prefigure uma situação nada confortável in loco, onde naturalmente não haverá possibilidade

relevância dois filmes do realizador Rodrigo Siqueira Arajeju: Índios no Poder (2015) e Índio Cidadão (2014).

112 Para uma etnografia da sociocosmologia guarani-mbya, Cf. PISSOLATO, Elizabeth. A duração da pessoa: mobilidade, parentesco e xamanismo mbya (guarani). São Paulo: Unesp Editora: Pronex: Nuti/ ISA, 2007. 
de um controle mais rígido da situação filmada, há uma importante reafirmação identitária que parece funcionar bem aos olhos e mãos dos não indígenas, como é possível notar no feedback elaborado por uma interatora francesa (por volta de junho de 2016), que solicita ao autor do filme a possibilidade de utilização de trechos em um outro filme de sua autoria.

Bomdia,

Eu sou uma francêsa que fez um documentário sobre os povos indígenas e o desmatamento no Brasil.

É um projeto voluntário e não comercial a ser transmitido gratuitamente na internet.

Eu falo um pouco do povo guarani e quer ter imagens para ilustrar o meu assunto.

Você me autorizar a reutilização de alguns segundos deste vídeo por favor? Vou enviar-lhe o filme com seu nome nos créditos.

Agradecemos antecipadamente

Mostrar menos

Responder •

fig. 15 - Comentário na página do youtube do filme "Rodovia Rojoko - 0 dia em que paramos a Bandeirantes - CGY". Disponível em: https://www.youtube.com/watch?v=JCBOU4wQmR8 Acesso: em 10/08/2016.

Há aqui um convite à reticularidade na evidência do comentário enquanto testemunho da intenção de continuidade, de proposição de um diálogo. Não há, até a data em que se recolhem estes dados, retorno por parte dos guarani ao comentário, no entanto não é difícil de se presumir que potencialmente as imagens deste filme tenham sido baixadas e reutilizadas e, por sua vez, ressignificadas no contexto de outros filmes.

Outro ponto a se destacar é o fato de que a interatora reporta-se a um sujeito individual, supostamente aquele que gerencia o canal onde os vídeos são veiculados, mas, no entanto, o próprio nome do canal sugere uma autoria coletiva, plural, a partir do usuário que o assina “Comissão Guarani Yvyrupa CGY". Isto nos chama atenção para aquilo deve ser uma característica fulcral nos processos de Produção Partilhada do Conhecimento, qual seja, a possibilidade de auto-gestão das ambiências, operacionalizadas pelos diversos interlocutores.

Ao final do filme, mais precisamente aos 2:49, a imagem em movimento dos guarani congela-se no exato instante em que um dos xondaro ${ }^{113}$ arma seu

\footnotetext{
113 Xondaro (pronuncia-se xondáro) é um termo guarani que abarca uma série de compreensões e sentidos pertinentes ao seu modo de vida e cosmovisão. Os próprios guarani assim refletem sobre o mesmo: "A palavra xondaro, em geral, vem do povo guarani, é muito comum ouvir esta palavra entre nós. A cultura guarani é muito complexa e rica - por abranger vários elementos e rituais sagrados que são de grande
} 
arco em direção ao extraquadro. Todos estão em torno novamente da faixa que pede pela demarcação dos territórios guarani e pelo fim dos projetos de lei e de emenda à constituição. No quadro seguinte, os dizeres: "Neike, xondaro kuery! Neike, xondaria kuery!", conclama os xondaros e xondarias para luta. Neste mesmo quadro, a possibilidade reticular se apresente no hiperlink "Participe!" que, ao ser clicado, nos levará à página da web da CGY. O vídeo segue com a convocatória dos atos de protesto. 0 final nos leva novamente à possibilidade explorar o segundo eixo, a partir do hiperlink "Clique e veja o vídeo-manifesto". Ao escolhermos esta opção e não a sequência automaticamente escolhida pelo youtube, passamos portanto ao eixo b.

\section{EIXO B - Manifesto: Por que fechamos a Bandeirantes? Comissão Guarani Yvyrupá}

O eixo B erige-se sob a justificativa dos motivos que levaram os guaranimbya a ocupar a rodovia dos bandeirantes a fim de ressignifcar este espaço. Se no eixo A tínhamos uma espécie de videoclipe, no eixo $B$, o vídeo se propõe a formar uma espécie de jogral em que 22 jovens alternadamente discursam ${ }^{114} \mathrm{em}$

importância para nós. 0 xondaro, por exemplo, é um dos elementos da nossa cultura. Consideramos o xondaro como certa prática para guerrear, mas nem mesmo nós sabemos ao certo como defini-la. Para saber e entender algo sobre o xondaro, precisamos primeiramente estar próximos dessa prática, porque é vivenciando, observando e praticando que nós aprendemos. Xondaro parece ser uma palavra sem importância, mas se nos aprofundarmos na pesquisa, a palavra começa a ter vários sentidos e significados, vai ficando muito complexo e difícil de se entender, pois o termo xondaro é um conceito que se refere à dança, a uma função e a um modo de se comportar" (p. 28) [itálico dos autores]. Cf: XONDARO Mbaraete: a força do xondaro. Coordenação editorial: Centro de Trabalho Indigenista (CTI). São Paulo: 2013.

114 Os 22 jovens dizem sequencialmente: "Hoje nós indígenas guarani de todas as aldeias de São Paulo fechamos pacificamente a rodovia dos bandeirantes, que passa sobre uma de nossas aldeias. Fizemos isso para vocês brancos saberem que nós existimos e que estamos lutando por nossas terras. Porque precisamos de terra para ter onde dormir e criar nossas crianças. Esse nome, "bandeirantes", para nós significa a morte dos nossos antepassados. Mas muitos de vocês brancos que estão aí tem muito orgulho deles e dos seus massacres contra nossa povo. Em homenagem a eles, vocês batizaram o palácio do governador e levantaram estátuas por toda parte. Há muitos que querem repetir o que fizeram os bandeirantes no passado nos exterminando e roubando nossas terras para enriquecer. Os políticos ruralistas, aliados do governo, querem aprovar a PEC 215, para suspender todas as demarcações que ainda faltam e ainda roubar terras que já estão 
pro-filmia, isto é, assumindo uma posição frontal em relação à câmera (o que revela sua existência enquanto dispositivo), aqui como um recado direto e objetivo. Este mesmo enquadramento que submetia povos indígenas ao crivo positivista (TACCA, 2002), quando em 1917 o Major Luiz Thomaz Reis os filmava em posição frontal e perfilados ${ }^{115}$, com o objetivo de registrar (duplamente) a antropometria, é agora ressignificado: As câmeras nas mãos dos guarani-mbya elaboram uma nova antropologia, reordenando o mundo visível no audiovisual do contexto pós-colonial.

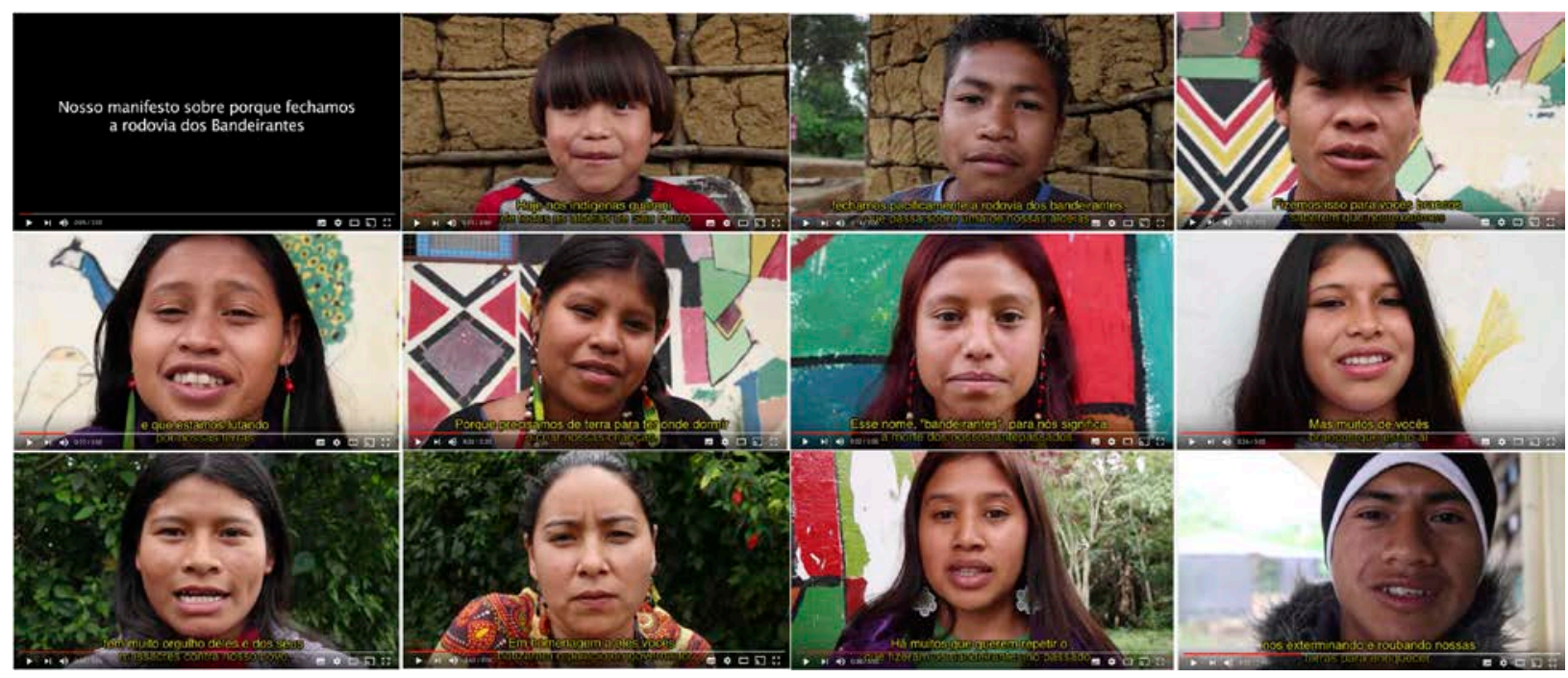

fig. 16 - 11 frames dos jovens guarani-mbya que, em pró-filmia, explicam olhando para a câmera o motivo pelo qual ocuparam a rodovia dos bandeirantes.

O filme prossegue a todo momento com canções guarani acompanhando a fala dos jovens. Ao final, mais especificamente em 2:39, a partir de três hiperlinks

demarcadas. Nossos guerreiros vão continuar resistindo e faremos o que for necessário para termos uma parte de nossas terras de volta. Nós somos os primeiros habitantes deste território. Será que há muita terra para pouco índio? Não é essa a nossa realidade. Vivemos no pouco que sobrou da Mata Atlântica, nossas terras são minúsculas e somos muitos. Enquanto que alguns políticos e empresários tem muita terra e ainda querem mais. Com este ato pacífico que fazemos agora exigimos: - Que os deputados arquivem a PEC215, e parem de tentar destruir nossos direitos. - Que o Ministro da Justiça publique as portarias declaratórias das Terra Indígenas Jaguará e Tenondé Porã. - Que o Governador do Estado retire as ações judiciais contra nossos parentes que têm áreas em sobreposição com Parques Estaduais. Juntos com nossos parentes do litoral faremos um grande ato na Avenida Paulista, no dia 2 de outubro, no vão livre do MASP. Convocamos todos os movimentos sociais e todas as pessoas que são contra a devastação da natureza e são contra a concentração de riqueza do país na mão de poucos latifundiários. Vamos às ruas nesse dia para mostrar que nesse país deve ter espaço para todos!"

115 Nos referimos aqui ao filme "Rituaes e festas bororo" de 1917 realizado pelo Major Luiz Thomaz Reis, a frente da "Secção de Photographia e de Cinematographia da Comissão Rondon". 
que surgem na tela, é possível voltarmos para o eixo A, irmos para o eixo C ("Mensagem à bancada ruralista"), ou nos direcionarmos à página da web da Comissão Guarani Yvyrupá.

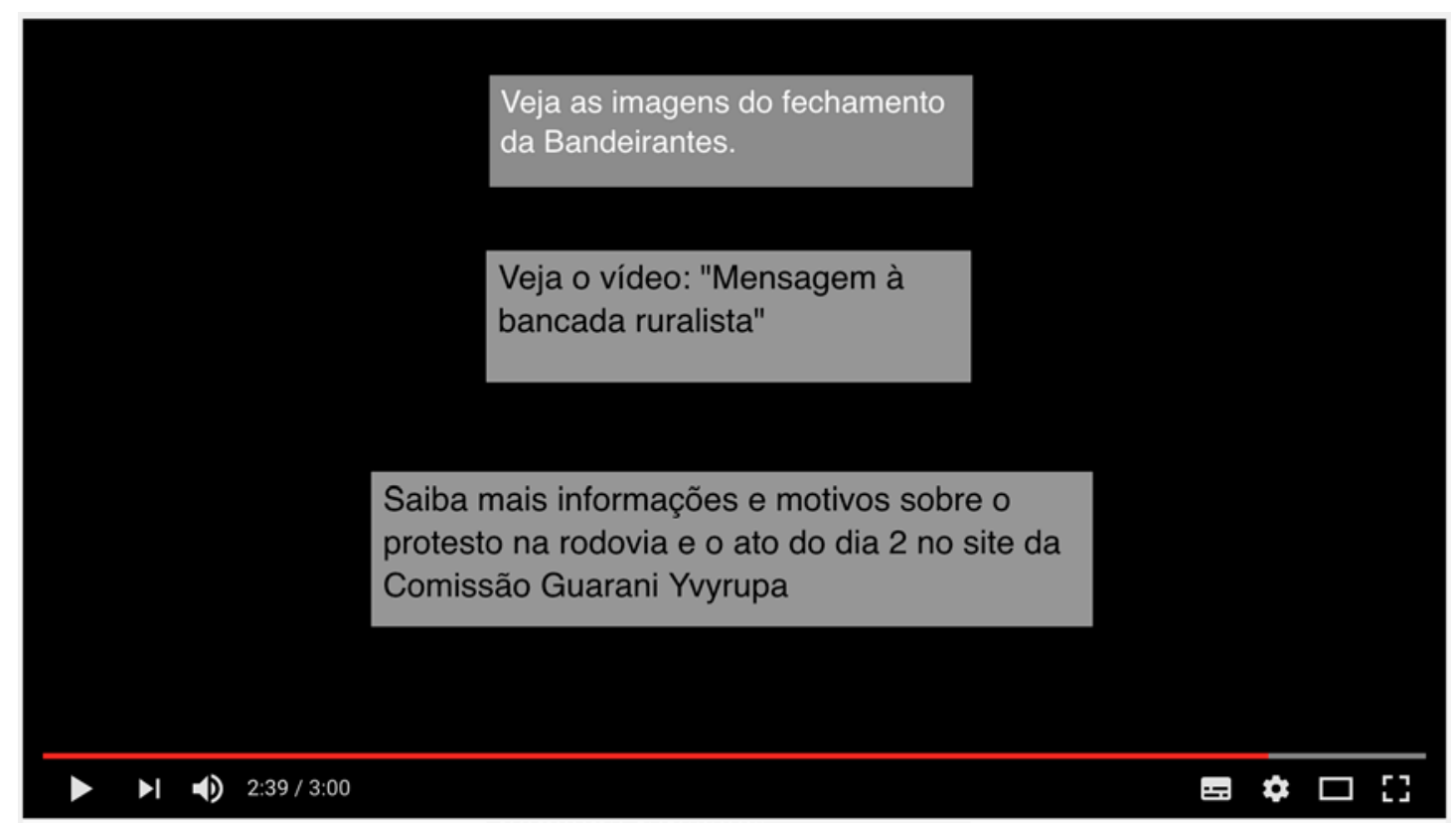

Fig.17 - Três hiperlinks nos dão as possibilidades reticulares ao final do vídeo Manifesto: Por que fechamos a Bandeirantes? Comissão Guarani Yvyrupá

\section{EIXO C - Mensagem à bancada ruralista}

Diferentemente do eixo $A$ e do eixo $B$, em que apenas o jovens protagonizam as demandas dos guarani-mbya, o eixo $\mathrm{C}$ apresenta uma mensagem do ancião Pedro Vicente Karai Mirĩ que endereça sua mensagem aos deputados do Congresso Nacional (sobretudo aos que propõem a alteração dos termos da Constituição relacionados as demarcações de terras indígenas) ${ }^{116}$.

${ }^{116}$ Diz Karai Mirĩ: "Eu sou do povo guarani. Meu nome é Karai Mir̃̃. Eu vivo aqui na aldeia Tenondé Porã, no município de São Paulo. Perto da cidade de São Paulo. Eu falo para vocês deputados que são donos de terra, que não mudem a Constituição, que não inventem mais leis para nos atrapalhar. Eu não estou de acordo com isso, não quero isso. Não quero nem um pouco. Então eu falo para vocês deputados que estão aí que me vejam, que me escutem enquanto eu falo. Foram vocês que criaram essa terra para si mesmos? Eu não fiz a terra onde vivo, e nem vocês fizeram. Vocês também não pagaram nada para Nhanderu (Nosso Pai). Mesmo assim, vocês querem levar toda a terra para 
Karai Mirĩ tranquilamente fuma um cachimbo e com serenidade discorre sobre assuntos que transversalmente perpassam a visão dos guarani-mbya a propósito da terra em conjunto com sua espiritualidade e sua cosmovisão. Em momentos singulares, Pedro inquire os deputados sobre como poderiam vender e apossarse de terras, incapazes que seriam de cria-las. Para Karai Mirĩ a estratégia é clara e não há o que temer. 0 corpo, como atesta nosso processo colonial, pode ser vitimado, mas para o guarani-mbya o não-indígena não terá a capacidade de tocar em seu espírito.

Ao final do eixo $\mathrm{C}$, não temos hiperlinks que possibilitem retornarmos ao eixo A. Temos, no entanto, a opção de voltarmos ao eixo B, assistirmos novamente à mensagem de Karai Mirĩ com legendas em inglês ou, como terceira opção, irmos para o vídeo "Baixa a bola ruralista!". Este último no entanto não é uma produção da CGY, mas uma animação de 7 minutos e 32 segundos - do canal

vocês como se vocês a tivessem criado. É só para ter essas coisas no coração que vocês se tornam deputados. Só para a cada quatro anos se preocuparem com a eleição. E por isso vocês querem destruir as leis que nos protegem. Acham que se nos exterminarem ficará melhor para vocês. Acham que Nhanderu vai cuidar melhor de vocês assim. Com isso eu fico furioso. Nem um pouco eu quero isso. É para termos onde dormir, para termos onde criar nossos filhos. Para isso querermos terra. Mas como não vendemos terra, vocês não querem devolvê-la para nós. Parece até que vocês fizeram essa terra, que vocês que fizeram as matas, que vocês que criaram a água. Nas cidades de vocês, se quisermos água, nós temos de compra-la. Temos que pagar para tomar água. Mas vocês não pagam para Nhanderu. Só querem tudo para vocês. É só para ficar ricos que vocês querem ser deputados, o pensamento de vocês está tomado por uma ganância descontrolada. Onde fica o coração de vocês? Quem de vocês se preocupa com os seus parentes que não tem onde dormir? Quem se importa com isso? Vocês não se importam, não sabem i que é ser solidário. 0 coração de vocês é ruim. É apenas para maldade que ele serve. Vocês não querem nem ver os pobres, quando os veem, vocês sentem nojo. Não é isso que Nhanderu quer. Ele quer que cuidemos todos uns dos outros, que tenhamos compaixão entre nós. Esta terra não é minha e não é de vocês. Não foram vocês que a fizeram e não fui eu. A terra que está aí é de Nhanderu! As matas e os pássaros que nela vivem. Mas não há mais árvores frutíferas para os pássaros se alimentarem. Vocês destruíram os animais de caça. Vocês destruíram tudo. Vamos viver numa terra deserta, devastada? Sem nada do que antes havia sobre ela, sem ter o que comer? E por isso estou bravo com vocês brancos, com os deputados. Por quê vocês só querem maltratar aqueles que sofrem? Colocar mais leis que dificultam a nossa vida? Como vamos ficar agora? Vamos todos nos destruir? Vocês querem enganar todos os índios. Querem me enganar. Se quiserem me matar, podem me matar. Mas o meu espírito vocês não podem matar. Ele vai voltar para a morada do meu pai celestial. Ele vai buscar meu espírito. 0 meu corpo vocês podem matar, hoje, amanhã, no dia que quiserem. Mas o meu espírito vai à morada de Nhanderu. É isso que eu tenho para dizer. Obrigado". 
homônimo ao vídeo -, que procura explicar as questões indígenas à luz dos direitos constitucionais e do âmbito econômico e político.

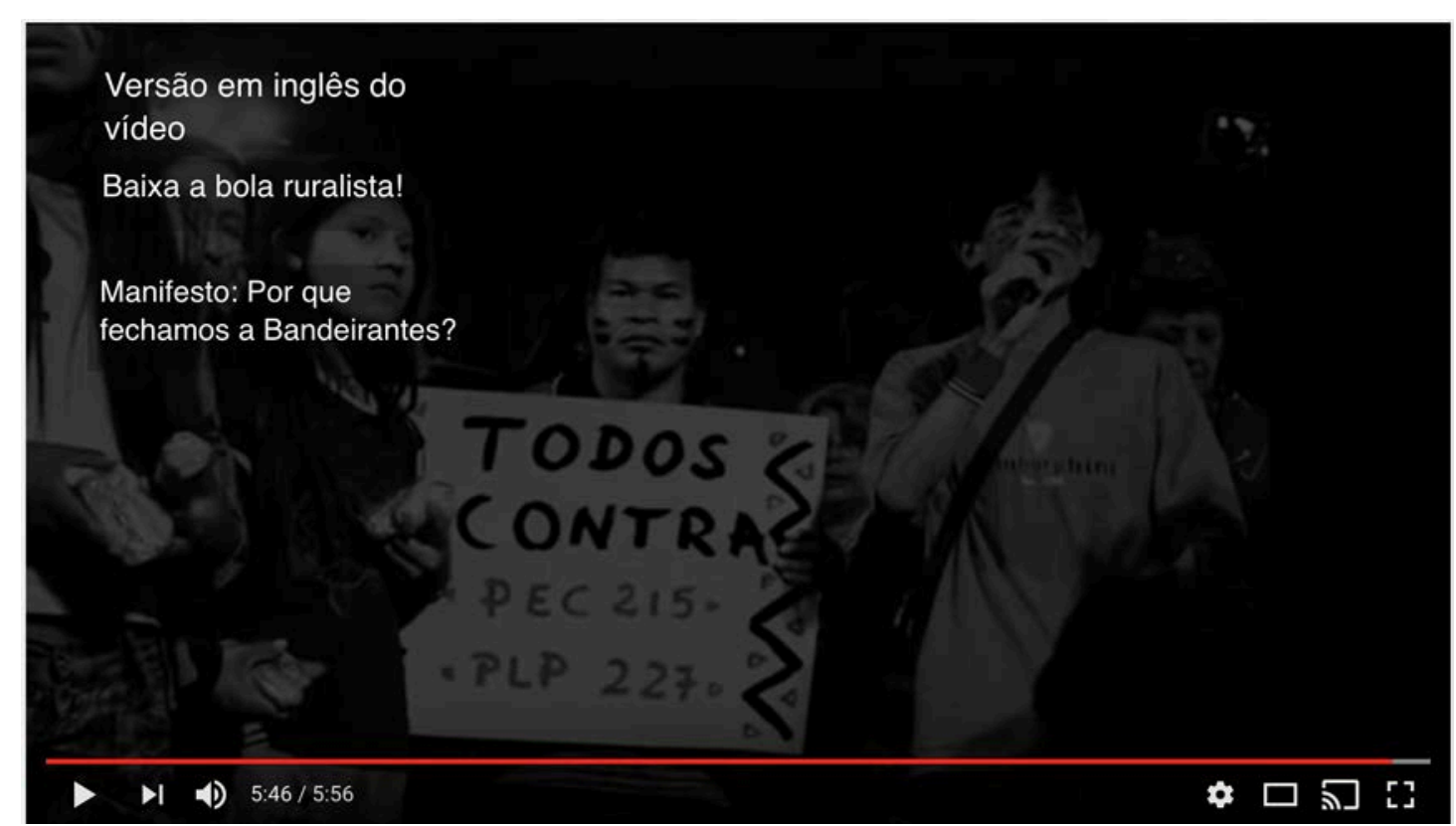

fig. 18 - Plano final do vídeo "Mensagem à bancada ruralista", oferece três hiperlinks.

\section{Reticularidade guarani: Uma media xondaro}

Os três vídeos acima citados, produzidos pela Comissão Guarani Yvyrupá, foram postados cronologicamente do seguinte modo: 0 "eixo C" (Mensagem à bancada ruralista), foi postado em 10 de setembro de 2013. O "eixo B" (Manifesto porque ocupamos a bandeirantes), foi postado no próprio dia da ação na rodovia, ou seja, no dia 26 de setembro de 2013. Já o "eixo A" (Rodovia Rojoko: O dia em que paramos a bandeirantes), foi postado no dia 30 de setembro, quatro dias após a ação. Compreendemos que, a despeito da cronologia inversa a da ordem das postagens, que aqui propusemos nossa navegação, há um percurso compreendido neste documentário hipertextual que nos leva a perpassar, por uma forma de ação, em um segundo momento uma justificativa para esta mesma ação (ambas protagonizadas pelos jovens xondaros 
e xondarias) e a escutarmos a opinião de um ancião (ou o imediato oposto em uma navegação principiando-se no eixo C). Naturalmente qualquer um dos vídeos poderia ser o primeiro exibido a partir dos mecanismos de busca da plataforma. No entanto, esta montagem hipertextual pressupõe a articulação entre a justificativa (o eixo do meio) e os dois outros vídeos (que aqui nomeamos eixo A e C). Isto significa que tanto ao começarmos pelo eixo A, quanto pelo eixo $\mathrm{C}$, temos a possibilidade de perpassar os três vídeos, sendo o eixo B esta articulação possível.

Embora o que aqui estamos chamando, com base na taxionomia de Gaudenzi (2013), de documentário hipertextual, apresente uma estrutura de navegação bastante simples e faça uso de um banco de dados pequeno, nos parece oportuno pensar sobre as estratégias de articulação que compreendem também as ambiências digitais enquanto um locus propício a um debate público e, portanto, a demandas de visibilidade para causas e populações historicamente alijadas dos processos políticos e decisórios que impactam sobre seus modos de vida. Como podemos notar, esta articulação tem-se mostrado, como no caso dos guarani-mbya, um importante fenômeno. 0 que aqui sugestivamente chamamos de media xondaro, vai na linha do que Shohat e Stam (2006) denominam "media jiu-jitsu", quando pensam as estratégias de resistência à dominação produzida a partir dos "dominados", isto é, as formas de ressignificação midiática de paradigmas da cultura dominante. Talvez ao pensarmos a estratégia guaranimbya, a sugestão da media xondaro mostre-se conceitualmente oportuna. Afinal, como pensam os guarani,

\footnotetext{
o xondaro faz parte de tudo na vida guarani: ele é o responsável por cuidar da aldeia, pela caça dos animais que comemos, ajuda no plantio e na colheita, ajuda xeramoi e xejaryi kuery (nossas lideranças espirituais) nos rituais da casa de reza, e ensina os mais jovens. Além disso, o xondaro é muito importante na nossa luta política, pela demarcação de nossas terras e pela garantia dos nossos direitos. Junto com nossas lideranças, é o xondaro que vai fazer manifestação política e mostrar nossa força. 0 xondaro também tem uma dança, que chamamos de xondaro jeroky Ela é uma forma de treinar e mostrar aos mais novos sobre aquilo que eles devem
} 
saber para ser xondaro, exercitando a força, agilidade, resistência, atenção e esquiva. 117

Assim, a figura do xondaro e xondaria pressupõe uma atuante interlocução, tanto nos assuntos que dizem respeito a vida na aldeia, como a um modo de expressar-se politicamente, isto é, na forma como de relacionar-se com o entorno, com os juruá (não-indígenas). A media xondaro que aqui analisamos, traduz as mesmas características inerentes que são atribuídas pelos guaranimbya aos seus guerreiros e guerreiras. A força empreendida em uma série de atos que pressupõe um objetivo partilhado; A agilidade demonstrada em uma media que rapidamente ocupou ambiências a fim de consolidar suas agendas; A resistência expressa sempre na iminência de uma nova desapropriação, de uma nova violência, de uma deslegitimação (assim como também se dá, no contexto digital, na violência a partir de comentários registrados nos vídeos). Como nas palavras de Karai Mirĩ, sua cosmovisão não teme uma espécie de apagamento / morte do corpo; neste âmbito pensamos que o digital potencialmente convertese na presença imanente de seu espírito, isto é, de suas ideias partilhadas a despeito do que as disputas de terra possam fazer consigo; A atenção circunscrita a um método que propõe uma articulação eficiente entre a ocupação territorial e a ocupação digital-reticular; A esquiva, como uma característica primordial de defesa ${ }^{118}$, da capacidade de desvencilhar-se de ataques inimigos, na media xondaro está expressa a partir da própria ocupação digital guarani, pois esta presença midiática indígena é uma forma de esquivar-se do tratamento que tradicionalmente recebem das medias hegemônicas, normalmente aliadas aos grandes setores econômicos: Estar presente é necessário, pois, para esquivar-se.

A população guarani-mbya que vive na cidade de São Paulo compreende por volta de duas mil pessoas ${ }^{119}$. A somatória dos três vídeos analisados,

\footnotetext{
${ }^{117}$ AGOSTO Indígena, 2015. Texto de autoria desconhecida, divulgado no contexto da Exposição "Agosto Indígena” na Galeria Olido em 2015.

${ }_{118}$ Aqui, naturalmente, lembramos também de uma outra manifestação cultural, a Capoeira, que compreende na "esquiva" um princípio importante.

119 De acordo com o Censo 2010 do Instituto Brasileiro de Geografia e Estatística (IBGE), disponível em:

http://www.ibge.gov.br/home/estatistica/populacao/censo2010/caracteristicas gerais indigenas/default caracteristicas gerais indigenas.shtm. Acesso em 05/02/2016.
} 
totalizam algo em torno de 12 mil visualizações. Há portanto, o equivalente a seis visualizações dos vídeos reticulares para cada guarani-mbya vivendo na cidade de São Paulo. Isto pode ser considerado um dado expressivo levando em conta novamente a baixa representatividade política e social de que gozam as populações indígenas no Brasil ${ }^{120}$. Neste sentido, poderíamos entender que a estratégia guarani, em sua ocupação digital-reticular, tem sido bastante efetiva. Como dito anteriormente, no ano de 2015 e 2016 foram alcançadas as metas da Comissão Guarani Yvyrupá quanto à assinatura das Portarias Declaratórias que demarcaram e posteriormente homologaram a "Terra Indígena Jaraguá" e a “Terra Indígena Tenondé Porã”. Outros processos e estudos encontram-se em curso e as mobilizações certamente continuarão a ocupar ambiências digitais e físicas.

120 Para uma análise histórica da relação das populações indígenas com o processo colonial na cidade de São Paulo, Cf. MONTEIRO, John Manuel de. Dos Campos de Piratininga ao Morro da Saudade: a presença indígena na história de São Paulo. In: Porta, Paula. História da cidade de São Paulo: a cidade colonial. vol.1. São Paulo, Paz e Terra, 2004. 
EIXO A

Rodovia rojoko - O dia em que fechamos a Bandeirantes - CGY

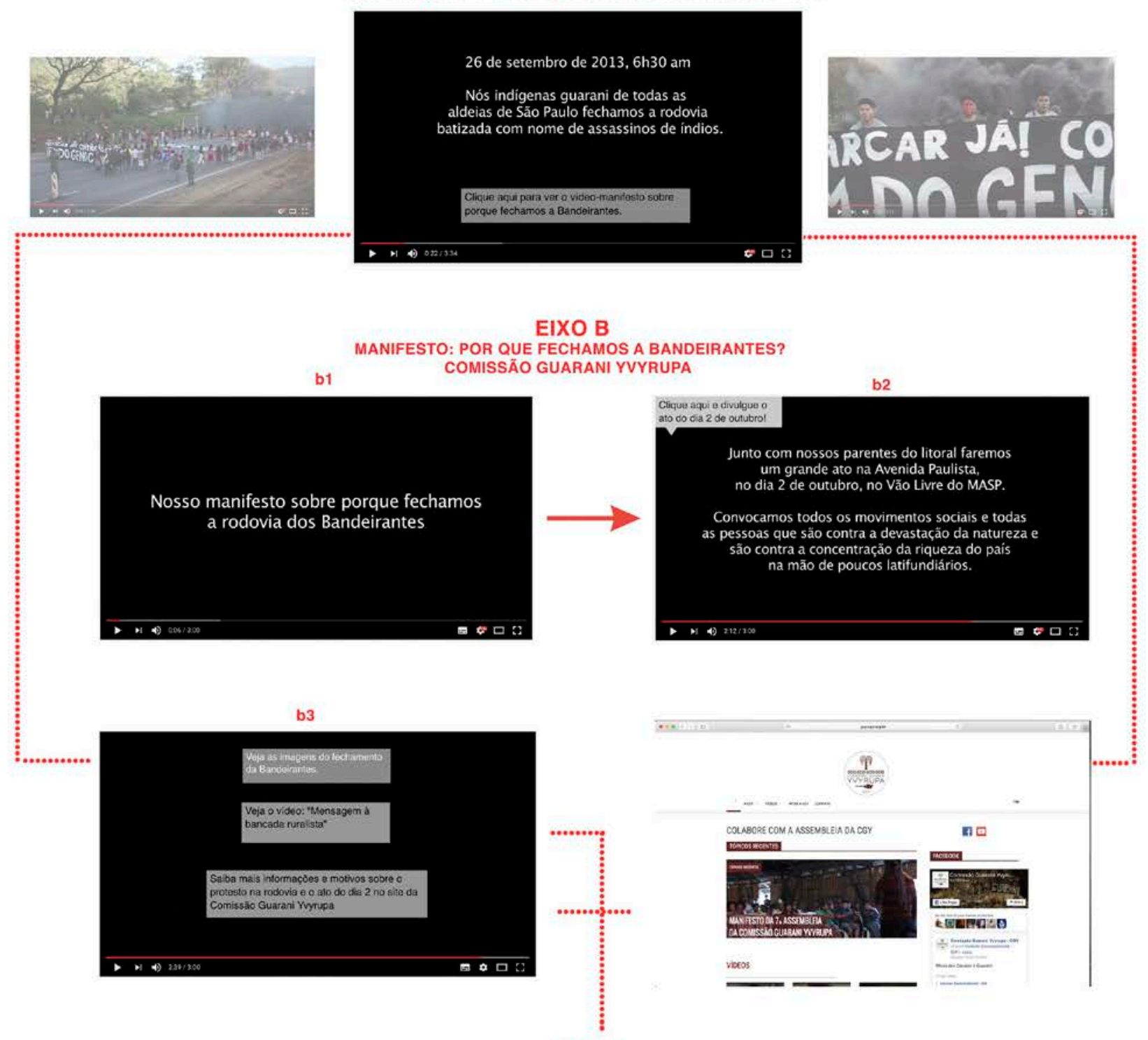

EIXO C

Mensagem à bancada ruralista
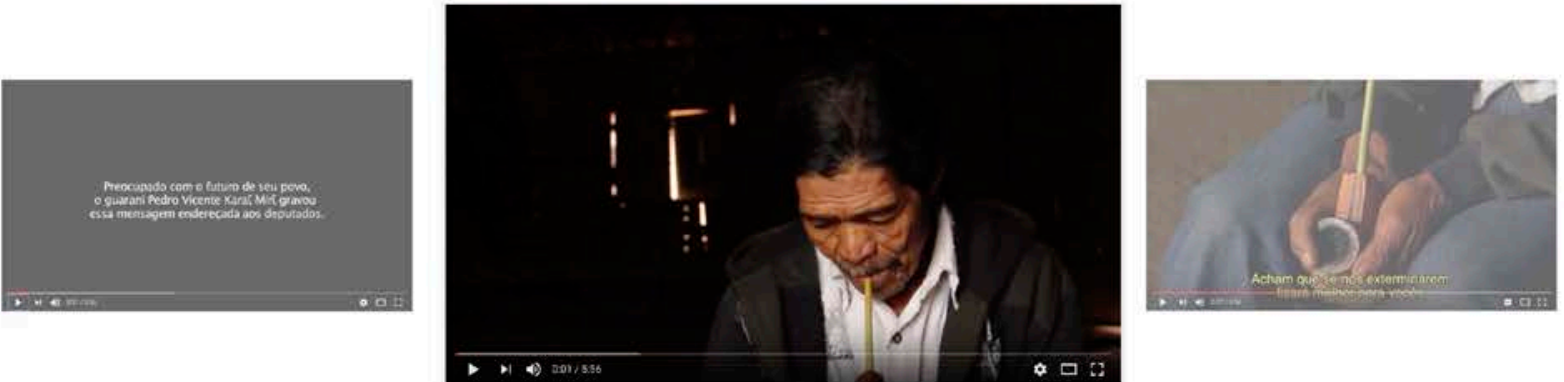

fig 19. Fluxograma da reticularidade fílmica guarani. 


\title{
CAPÍTULO IV
}

\section{PRODUÇÃO PARTILHADA DO CONHECIMENTO}

\author{
partir \\ Partir \\ da ilha \\ dos pensamentos \\ isolados \\ dos departamentos \\ apartados. \\ Partir \\ da ilha \\ para os campos \\ sensíveis do \\ conhecimento \\ da Partilha.
}

Neste capítulo, propomos transitar entre bases/fios epistemológicos que suscitam interlocuções possíveis a partir da Produção Partilhada do Conhecimento. Esta tarefa consiste em um esforço evidentemente amplo e que, invariavelmente, escapa às conjecturas de uma única pesquisa. Trata-se aqui de contribuir para o processo fulcral de pensamento do que temos denominado "Produção Partilhada do Conhecimento". Neste sentido, compreendemos uma aproximação possível e necessária com outros aportes teórico-metodológicos em iniciativas como a Antropologia Partilhada de Jean Rouch (RIBEIRO, 2007; ROUCH, 1995; SZTUTMAN, 2004), a Pedagogia Griô (PACHECO, 2015), bem como a Pesquisa-ação (THIOLLENT, 2011).

é necessário, pois,
que desfaçamos
o tratado
das torpes ilhas, anunciado no descobrimento da moderna ciência. 


\title{
As bases reticulares da Antropologia Partilhada
}

\author{
sujeito participante \\ O particípio \\ do sujeito \\ não é sujeitado. \\ o sujeito \\ do particípio, \\ multivíduo, \\ é um sem jeito, \\ insubordinado.
}

Nos idos dos anos de 1950, Jean Rouch consolidava sua transição para o cinema, mais especificamente em estrita relação com a etnografia - embora, desde então, permaneça, até o fim de sua vida, em uma espécie de fronteira porosa (e subversiva!) entre o cinema e a antropologia - fruto sobretudo de sua larga experiência em campo na África ${ }^{120}$. Podemos compreender que a aproximação do cinema e da antropologia, concordando com Piault (2002, p.25) está na “[...] designación de lo humano a través de sus diferentes identificaciones, la aprehensión de sus limites, de sus variantes, las modalidades de su inserción y de su control del entorno que lo condiciona, las condiciones generales de su adaptación y de su compresión del mundo"121, premissas estas que transcorrem toda a cinematografia de Rouch.

Enquanto signatário de Flaherty e Vertov no documentário - aqueles que seriam, segundo ele, seus "pais totêmicos" -, sua prática viria a consolidar-se como uma experiência de "cinema-verdade", ou como ele definiria posteriormente: "Não um Cinema Verdade, mas a verdade do cinema"122 (ROUCH 1995). Edgar Morin, parceiro de Rouch naquele que talvez tenha sido o principal experimento do cinema verité - o filme

120 Jean Rouch, engenheiro de formação, conhece a África em 1941, mais especificamente trabalhando na construção de estradas e pontes na República do Níger. Esta vivência é fundamental para sua transição da engenharia para o cinema e a antropologia. Em 1947 principia seu doutorado em Etnologia na Sorborne, com orientação de Marcel Griaule, com uma pesquisa sobre a feitiçaria, possessão e sacrifício entre os Songhay.

121 Tradução nossa: "designação do humano através das suas diferentes identificações, a apreensão dos seus limites, das suas variantes, as modalidades da sua inserção e do domínio do meio que o condiciona, as condições gerais da sua adaptação e compreensão do mundo".

122 ROUCH, Jean. "Entrevista com Jean-Paul Colleyn". Cadernos de Antropologia e Imagem (1), Rio de Janeiro, UERJ, 1995. A propósito das distinções e aproximações entre o cinema-verdade e o cinema-direto Cf: DA-RIN, Silvio. Espelho Partido: Tradição e transformação no documentário. Rio de Janeiro: Azougue Editorial, 2004, sobretudo os capítulos 7 "Uma testemunha discreta" e 8 "Verdade e Imaginação". 
"Crônica de um verão", de 1960 - sintetiza a definição a propósito desta corrente no entendimento de que

Il y a deux façons de concevoir le cinéma du réel: la première est de prétendre donner à voir le réel; la seconde est de se poser le problème du réel. De même, il y avait deux façons de concevoir le cinéma vérité. La première était de prétendre apporter la vérité. La seconde était de se poser le problème de la vérité. ${ }^{123}$

Na compreensão de Rouch e Morin, esta verdade seria uma construção, subsumida, um reencontro com a verdade a partir da cine-montagem como em Vertov, e, sobretudo, parte de um processo em que os sujeitos produzem questionamentos diante do mundo, a respeito do mundo e a respeito de si mesmos. Morin assim sintetiza a experiência proposta em Crônica de um Verão:

0 tema da cidade em Crônica de um verão era implícito, [...] esse lado implícito era muito forte, porque o tema do filme... 0 filme deveria se chamar 'Como tu vives?' ou seja, como cada um se confronta com seus problemas, não somente materiais, mas também psicológicos, morais, afetivos, etc. E, evidentemente, todas essas pessoas que entrevistamos se encontravam na cidade grande: Paris. Na capital. E cada um tinha encontrado obstáculos lá vez ou outra. Então, se assim se quiser, eles todos foram confrontados com o problema da cidade, ou seja, uma cidade que é às vezes atrativa - é o tema da Cidade Luz -, e, após, uma cidade que continuando Cidade-Luz, torna-se uma cidade tentacular, uma cidade que sufoca e, no fundo, é talvez essa ambivalência que se sobressai no filme. Então, a cidade, no fundo é o concentrado de toda a civilização, é aí que se encontram todas as ambivalências e todos os problemas e, no fundo, o tema, quando fizemos a pergunta 'Você é feliz?' - era uma pergunta um pouco estimulante, um pouco ingênua -, vê-se muito bem que essa pergunta desconcerta a maioria das pessoas. Ou seja, elas não estão acostumadas a poder falar da felicidade, ou seja, daquilo que há de mais importante na vida. ${ }^{124}$

Nesta experiência de cinema-verdade, Rouch e Morin valorizam no filme a dimensão de uma subjetividade relacional, isto é, buscam aleatoriamente e incessantemente propiciar o encontro entre sujeitos que, a partir desta proposição,

123 Tradução nossa: "Há duas maneiras de conceber o cinema do real. A primeira é a pretensão de se ver o real; a segunda é se colocar o problema do real. Da mesma forma, havia duas maneiras de entender o cinema verité: A primeira reivindicando a verdade. A segunda foi colocar o problema da verdade". “CINÉMA ET VÉRITÉ PAR EDGAR MORIN (1980)” Disponível em: http://piermarton.info/cinema-et-verite-par-edgar-morin-1980/ Acesso em: 05/03/2015. 124 FRONTEIRAS DO PENSAMENTO, 2015. Entrevista com Edgar Morin, disponível em: https://www.youtube.com/watch?v=yQUMFJIh3bw Acesso em: 10/09/2015. 
passam (e passamos enquanto espectadores) a vivenciar semelhanças e divergências e a tecer portanto relações com esta experiência da verdade do cinema. Esta premissa é herdeira, pois, da compreensão de Vertov, com grande ênfase à especificidade cinematográfica por ele (e por seu grupo, os kinoks) defendida, na qual o cine-olho deveria, sem fazer concessões,

[...] mostrar pessoas sem máscara, sem maquiagem, captá-las com o olho da câmara no momento em que não representam, ler os seus pensamentos revelados pela câmara. O Cine-Olho como possibilidade de tornar visível o invisível, límpido o suave, evidente o que é escondido, manifesto o que é mascarado. Substituir o jogo pelo não jogo, a falsidade pela verdade, pelo 'Cinema- Verdade'”125.

O aparente paradoxo contido neste excerto de Vertov passa pela premissa de que, para ele, fundamentalmente, o cinema é montagem e, portanto, esta "verdade" - a cinematográfica -, estaria propriamente submetida a um exercício de montagem, onde o deciframento do mundo somente é possível a partir dela. É a montagem em conjunto com o cine-olho que é capaz de "tornar visível o invisível", "evidente o que é escondido", uma vez que possui a capacidade de reordenamento do mundo visível e, portanto, da construção de novos sentidos não previstos na causalidade dos acontecimentos. Neste sentido, ressaltamos que o motor da cinematografia vertoviniana é, por excelência, a ideia do acaso, da vida de improviso, onde a montagem atua como uma espécie de maestro a reger o cotidiano ${ }^{126}$.

A tradição da chamada vanguarda soviética havia de certo modo conjugado o cinema em uma relação mais próxima com a cientificidade, seja em proposições teóricas bastante elaboradas como no caso de Eisenstein, ou na concepção cinematográfica que inter-relacionava-se com a engenharia, o design, e outras áreas do pensamento humano, como em Vertov e a escola construtivista. Os soviéticos contribuíam assim para inserir o

125 Disponível na língua em:

http://revuemanifeste.free.fr/numeroun/manifestedv.html. (Tradução nossa). Acesso em: 01/10/2016. Alguns dos manifestos de Vertov e do Conselho do Três encontram-se disponíveis, em língua portuguesa, em "Dziga Vertov" In: XAVIER, Ismail (org.). A experiência do cinema. Rio de Janeiro: Graal, 1983. pp. 245-266.

126 É importante ressaltarmos que a percepção sonora do mundo teve grande influência no conceito de montagem elaborado por Vertov. Como destaca Bairon (2008), Vertov, ainda na década de 1910 - antes de suas primeiras experiências cinematográficas - "criou o Laboratório do Ouvido que visava a pesquisa e o registro sonoro dos mais variados fenômenos do cotidiano, como falas, ruídos etc. Nesta época, fez várias experiências com gravação da recitação de poemas, tendo ao fundo uma grande variedade de sons". 
cinema enquanto uma mola propulsora adaptada aos questionamentos das mais diferentes naturezas, bem como às possibilidades de desvelamento do mundo.

Este pretenso hibridismo no cinema, para além do que convencionamos chamar de "arte", certamente influenciou Rouch e sua geração. Em 1972, em um diálogo com Marcorelles ${ }^{127}$, Rouch afirma sua descrença quanto à "objetividade científica"128 ao mesmo tempo em que magistralmente compreende-se em uma posição híbrida, produto de alguma indefinição dos campos: "Eu me considero ao mesmo tempo como cineasta e etnólogo. Eu acho que a etnologia é poesia. Não acredito muito nas ciências humanas, como já disse várias vezes. Afinal de contas, as ciências humanas são algo terrivelmente subjetivo" (ROUCH apud DA-RIN, 2004).

Partilhamos, pois, também de outra percepção de Rouch, quando salienta, “[...] eu já havia refletido muito sobre o absurdo de escrever livros inteiros sobre pessoas que nunca teriam acesso a eles, e aí, de repente, o cinema permitia ao etnógrafo partilhar a antropologia com os próprios objetos de sua pesquisa"129. (ROUCH apud MONTE-MOR in TEIXEIRA, 2004). A partir destes excertos recolhidos, encontramos um sujeito que atua sobremaneira em duas direções; A primeira questiona os princípios do método científico, associados evidentemente à pesquisa em ciências humanas e, outrossim, questiona a insuficiência do livro, enquanto suporte para uma Antropologia Partilhada. A segunda direção compreende pois uma insuficiência na antropologia como até então pensada. Isto é, não uma insuficiência em uma premissa epistemológica, posto que isto é inerente à todas as ciências, mas quiçá uma insuficiência naquilo que ele passa a defender enquanto um princípio de feedback. Em conversa com José da Silva Ribeiro, Rouch diria que:

No filme etnográfico, para mim, a coisa mais importante é o feedback, isto é a devolução às pessoas que filmámos do filme que fizemos sobre elas. Tal não acontece a maior parte das vezes na Etnografia clássica, na Etnografia dos outros... Poucas pessoas filmadas por quem quer que seja viram os seus filmes. Nenhuma das pessoas observadas por Boas, Margaret Mead, Griaule, LeroiGourhan, Lévi-Strauss, puderam ter acesso aos livros que fizeram sobre eles. (ROUCH in RIBEIRO, 2007)

127 L'Avant Scene, no123, 1972 (citado por DA-RIN, 2004).

128 Piault (2002) chama de "tentação fantasmática da objetividade" à tendência de suprimir da captação aquele que a registra.

129 Percepção esta relacionada ao suporte "livro" que, como vimos no capítulo anterior, enseja alguma aproximação com a ideia do livro esférico defendida por Sergei Eisenstein, embora a crítica de Rouch centre-se a propósito do hermetismo do texto científico. 
Por outro lado, para Lévi-Strauss, por exemplo, o cinema, na interface com a antropologia, não poderia ser encarado com seriedade maior do que os registros dos cadernos de campo antropológicos, como expôs em uma entrevista na Cahiers $d u$ Cinema, em 1964: "Eu admito o cinema-verdade, mas no mesmo nível que os cadernos do etnólogo ou do sociólogo trabalhando no campo. À diferença de nós, antropólogos que não publicamos as nossas anotações, são de uso interno" (LÉVI-STRAUSS apud SZTUTMAN, 2004). Rouch, a seu modo, avançava portanto em um terreno que lhe demandava um desafio vertiginoso frente à sua contestação a uma certa tradição academicista francesa (embora esta mesma lhe fosse proveitosa com relação à tradição anticolonialista presente em sua antropologia), inaugurando assim tendências filiadas propriamente a um certo pensamento pós-estruturalista ${ }^{130}$.

Como destaca Sztutman, Rouch rejeitava a antinomia ciência x arte, visto que definia "o filme etnográfico como aquele que alia a arte da exposição cinematográfica ao rigor da enquete científica" (ibid, p. 51). Além desta fértil composição, Rouch aprimora a partir de sua Antropologia Partilhada a noção de feedback, propondo um reencontro, no liame do cinema e da antropologia, entre ética e estética no esteio da forma partilhada como concebe sua produção. Esta noção pode ser notada em sua pequena crônica a respeito da recepção de seu filme sobre a caçada dos hipopótamos no Niger - Bataille sur le grand fleuve (um de seus primeiros filmes africanos) - em que reflete:

Tinha feito em 1951 um filme sobre a caça ao hipopótamo e tinha apresentado esse filme aos pescadores. Eles nunca tinham visto cinema na vida deles. Instalámos um pequeno gerador eléctrico, pusemos a máquina em movimento, colocamos um lençol numa casa e pusemo-nos todos à volta da máquina. Depois esperámos que anoitecesse. A noite chegou os presentes aperceberam-se do que estava lá, que não era a câmara. Olharam e reconheceram-se.

130 Marco Antônio Gonçalves (2008), por sua vez, entende que há no cinema de Jean Rouch uma filiação bastante próxima ao surrealismo: "É no próprio texto de Breton (1948) que encontramos a valorização da criação enquanto produção, o que nos remete diretamente à proposta de Rouch. Destaca-se, nas palavras de Breton, uma ênfase da criação sobre a imitação e do vivido sobre o pensado. Desta forma o surrealismo, tal qual proposto por Breton a partir de seu próprio método baseado na escrita automática, dava maior liberdade à criação, produzindo um triunfo da arte da imaginação e da criação sobre a arte da imitação. Neste sentido, o surrealismo propunha algo novo, da ordem da imaginação, da liberdade de criação, da criatividade, do vivido [...] A concepção de filme e, mesmo, de câmera para Rouch, procurava realçar este universo criativo desembocando num novo estilo de fazer Antropologia ao deixar fluir este automatismo e, consequentemente, a criatividade no momento mesmo em que a câmera era ligada". (pp.79-80). Cf: GONÇALVES, Marco Antônio. 0 real imaginado. Etnografia, cinema e surrealismo em Jean Rouch. Rio de Janeiro, Topbooks/ Capes, 2008. 
Em menos de um minuto compreenderam a linguagem. Puseramse entretanto a chorar, porque uma das pessoas que viam tinha já falecido. [...] Os participantes que tinham vindo ver o filme foram buscar à aldeia a viúva de um das pessoas falecidas. Pôs-se a chorar ao ver o seu marido quando ainda o víamos vivo. Depois fizemos outras projecções nessa noite e ao fim da sétima eles ouviram. Pela primeira vez essas pessoas que eu estudava, que conhecia, há muito tempo, criticaram-me. Disseram-me: "Não está bem"! Eu tinha-lhes enviado a minha tese, eles conheciam-me como engenheiro, construí uma estrada na terra deles, e eles pensavam que, depois da guerra, eu tinha enlouquecido, como os antigos combatentes. Tinha máquinas estranhas, tomava notas, mas afinal, não era má pessoa. Por isso, estava tudo bem e de repente, eles compreenderam e disseram-me: "Não está bem!". Não se veem hipopótamos suficientes. 0 que eles me pediam era para fazer como Cousteau - ir para debaixo da água. Bom, tinham razão. Segundo, disseram-me uma coisa que é muito importante para mim. Disseram-me: "Mas, tu puseste música, na caça?" Aí eu defendi-me. Disse: Sim, é uma música que dá coragem aos caçadores. Eles disseram-me: "Então mas tu não sabes que o hipopótamo debaixo de água ouve, e se ouve música vai-se embora. ${ }^{131}$

Neste sentido, Rouch alargava o terreno inaugurado por Flaherty, que em suas experiências de campo também consultava-se com os atores sociais dos filmes (a propósito do próprio filme), como os inuits durante a rodagem de "Nanook of the North". E desenvolve assim as bases de sua Antropologia Partilhada, com ênfase primeiramente na noção de feedback, mas que paulatinamente cresce para proposições, por exemplo, da co-autoria, como em Moi, un noir ${ }^{132}$, de 1958. No lugar do imaginário colonial da "descoberta", da revelação dos segredos ocultos, da surpresa exotizante diante dos modos de vida nativo, seu processo de produção de conhecimento, em antropologia a partir do cinema (e vice-versa), enseja

[...] este permanente cine-diálogo que me parece um dos ângulos interessantes do atual progresso etnográfico: conhecimento não é mais um segredo roubado para ser mais tarde consumido nos templos ocidentais de conhecimento. É o resultado de uma busca interminável onde etnógrafos e etnografados se encontram num caminho que alguns de nós já chamam de 'Antropologia Compartilhada'.133 (ROUCH apud GONÇALVES, 2008).

\footnotetext{
131 RIBEIRO, 2007.

132 Nota-se que, a despeito de investir em um processo de co-autoria narrativa, neste citado filme um dos letreiros iniciais anuncia "Un film de Jean Rouch".

133 In ROUCH, Jean. "Jean Rouch with Enrico Fulchignoni”. In: Feld, S. CineEthnography - Jean Rouch. (Visible Evidence, 13). Minneapolis, University of Minneapolis Press. pp. 147-187. 2003
} 
No interior destas proposições, Rouch realiza um desvio do curso caudaloso da antropologia de terreno - bem como poderíamos compreender, grosso modo, de grande parte das ciências humanas. Onde esta, ao lidar com as comunidades e interlocutores a partir dos quais se estabelece sua produção de conhecimento, empreende pesquisas em que, como diria Viveiros de Castro (2002, p.115), "o discurso do nativo não detém o sentido de seu próprio sentido", e para além, "o conhecimento por parte do sujeito exige o desconhecimento por parte do objeto" (p. 116). Circunscrito ao âmbito da Antropologia, Viveiros de Castro compreende ainda que

\begin{abstract}
A relação diferencial do antropólogo e o nativo com suas culturas respectivas, e portanto com suas culturas recíprocas, é de tal ordem que a igualdade de fato não implica uma igualdade de direito - uma igualdade no plano do conhecimento. 0 antropólogo tem usualmente uma vantagem epistemológica sobre o nativo. 0 discurso do primeiro não se acha situado no mesmo plano que o discurso do segundo: o sentido que o antropólogo estabelece depende do sentido nativo, mas é ele quem detém o sentido desse sentido - ele quem explica e interpreta, traduz e introduz, textualiza e contextualiza, justifica e significa esse sentido. (2002, pp. 114-115)
\end{abstract}

Trata-se aqui do cerne do método científico, que amparado nos moldes da ciência moderna, crê que a divisão entre o sujeito do conhecimento e os sujeitados a este mesmo, onde um é o motor da episteme e o outro seu combustível, seria uma forma eficiente de produzir o conhecimento. Como lembra Santos (2005, p.22), a ciência moderna que principia a determinar o que é o conhecimento válido sobre o mundo a partir, sobretudo, do século XVII, "conquistou o privilégio de definir não só o que é ciência, mas muito mais do que isso, o que é conhecimento válido". De fato, assim tem-se mostrado, ao menos no seio de toda a estrutura que erigiu-se desde então, subsidiada pois em uma ampla tradição com base nestes mesmos fundamentos.

Marília Librandi Rocha (2014), no âmbito dos estudos literários, por exemplo, a partir do que chama de uma "literatura com terra e das gentes", reivindica o direito à presença da carta Guarani-Kaiowá134 (da comunidade Pyelito Kue) na Literatura Brasileira, e pensa no que seria uma "terceira vereda", enquanto potencial referencial pós-colonial, para pensar o texto indígena dentro do campo literário, compreendendo-o como espaço discursivo de acolhimento e produção de diferenças, fugindo deste modo do afã de uma violência tradutora. Rocha lembra, portanto, que o que tradicionalmente 
se compreende como o marco inaugural da literatura brasileira, é a carta de Pero Vaz de Caminha, no princípio da ocupação portuguesa135. Como aponta Rocha (2014) a literatura no meio científico tratou de afastar de seu cânone tudo o que diz respeito ao texto extraocidental. Seria possível pensarmos, a partir de sua perspectiva, em uma literatura partilhada com terra e das gentes, na qual o texto coletivo, comunitário, opera de outros modos. Rocha (2015) também cria uma poética composição ao que chama de "escritas de ouvido", na qual considera "uma qualidade distintiva da literatura brasileira: seu ouvido aguçado, ou em outras palavras, a proximidade de sua escrita com a captação de timbres e de nuances, acentuados no interior de uma cultura em que a oralidade e a música predominam" (ibid, p. 132). A literatura com terra e das gentes partilha também os princípios da oralidade e da experiência estética.

Sob o risco do "epistemocídio" (SCHOLTE apud CASTRO, 2002), isto é da contínua deslegitimação da ciência "não científica" da perspectiva do "nativo", como necessária para legitimar a "ciência" do investigador em ciências humanas (ele, de outro modo, também o "nativo" do "nativo"), incorre uma reflexão premente sobre epistemologias outras, como nos termos de Latour (1994), de uma "antropologia simétrica", ou da investigação, na interface entre a antropologia e o cinema, uma "antropologia partilhada", como proposto por Rouch.

Poderíamos de algum modo refletir que, em Produção Partilhada, o pesquisador é também um "nativo" para o "nativo", e o habitualmente considerado "nativo" é também ele um "pesquisador". Isto é, afinal, visto que empreende, a seu modo, suas formas específicas de investigação. Esta premissa, porém, não fundamenta-se nem sob uma ideia de homogeneização do conhecimento (supostamente entre o pesquisador e o nativo, um binômio insuficiente como vimos) e nem, tampouco, de exclusão da diferença mas, de outro modo, da conjugação dos sentidos, afetos e diferentes formas possíveis de produção do conhecimentos inauguradas pelo encontro.

Há ainda, um outro aspecto que valorizamos nas proposições de Rouch em suas relações com a Produção Partilhada. Trata-se da dimensão sensível atribuída ao pesquisador/realizador, em campo, a qual traduz-se em uma relação íntima, transitiva,

${ }^{135}$ A este propósito, Rocha (2014, p. 167) diz: "A Carta Guarani Kaiowá não pertence de modo algum ao campo do ficcional, mas pode pertencer ao campo do literário, assim como a carta de Pero Vaz de Caminha, as Cartas Jesuítas, os Sermões do Padre Vieira, os muitos tratados descritivos, relatos de viagem e outros documentos histórico-sociais que integram o acervo da literatura produzida no Brasil, pois alcançaram uma dimensão que ultrapassou seu território de inscrição inicial". 
com a experiência estética e as dinâmicas das culturas orais. A isto, Rouch chama de cine-transe, isto é, uma ideia que “[...] deve ser pensada não só de forma metafórica, mas como resultado de uma experiência sensorial que resulta numa prática cinematográfica onde o corpo do cineasta é afetado pelos fenômenos que observa, uma cine-antropologia corpórea, sensível” (HIKIJI, 2013, p. 117). Rouch (2003, p.43) assim definiria,

Thus instead of using the zoom, the cameraman-director can really get into the subject. Leading or following a dancer, priest, or craftsman, he is no longer himself, but a mechanical eye accompanied by an electronic ear. It is this strange state of transformation that takes place in the filmmaker that I have called, analogously to possession phenomena, "ciné-trance." 136

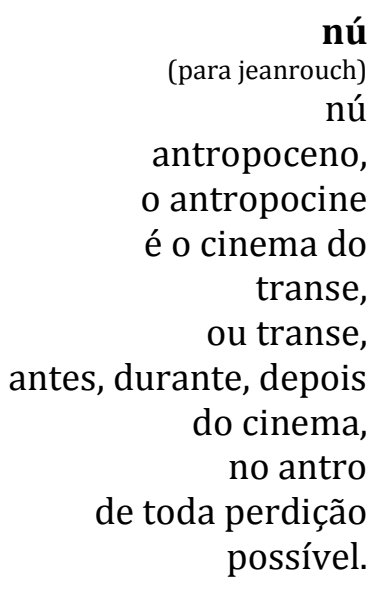

Ao responder à José da Silva Ribeiro (2007,), que lhe pergunta sobre qual deveria ser a formação para alguém que quer fazer filmes etnográfico, Jean Rouch diz, inusitadamente, que seria essencial aos etnógrafos aprender o latim. Afinal, o verso latino é composto pelas últimas palavras para se obter a rima. E, no seu entendimento, "o cinema é isso [...] Assim monta-se um filme ao contrário. Parte-se da última imagem e faz-se a montagem para sabermos para onde vamos. E é assim que eu faço a montagem e é também assim que faço a realização" (ibid, p.39). Bem como vimos, de forma semelhante, Rouch compara o cinegrafista (em cine-tanse!), em situação de rodagem,

136 Tradução nossa: Assim, ao invés de usar o zoom, o cinegrafista-diretor pode realmente aproximar-se do sujeito. Dirigindo ou seguindo um dançarino, padre ou artesão, ele não é mais ele mesmo, mas um olho mecânico acompanhado por uma orelha eletrônica. É este estranho estado de transformação que ocorre no cineasta que chamei, analogamente aos fenômenos de posse, "ciné-transe". 
com um músico que improvisa em um jazz. Compreende-se portanto na câmera-transe de Rouch um híbrido poético- musical.

Com base em Rouch e na Antropologia Partilhada, passamos pois a perímetros que nos são mais próximos. No Brasil, o trabalho envolvendo a produção de vídeos junto aos povos indígenas, tem possibilitado, como vimos, o enfrentamento de questões políticas, jurídicas, territoriais, culturais, etc. Esta proposição, desenvolvida com ênfase desde pelo menos o advento do VHS (graças também a uma maior portabilidade dos equipamentos de registro), conseguiu principiar uma democratização da realização audiovisual e dotar de visibilidade muitos povos, visto que a produção em vídeo não depende da complexa logística envolvida no registro em material sensível e a posterior revelação. 0 trabalho dos kayapó junto ao antropólogo Terence Turner, a partir da década de 1980, é um exemplo desta apropriação necessária.

Outro trabalho a se destacar, consiste na trajetória de mais de três décadas da ONG indigenista "Vídeo nas Aldeias"137 - que para Bernadet (ARAUJO, 2011) trata-se de uma verdadeira "filosofia da alteridade" - como também um marco no uso do audiovisual a favor dos povos indígenas. Ambas experiências foram fortemente inspiradas na perspectiva da Antropologia Partilhada138. Práticas estas que também inspiraram antropólogos, documentaristas, comunicadores, no ensino e aprendizado da etnografia tendo como base o documentário no mundo todo.

1370 projeto Vídeo nas Aldeias se desenvolve, a partir de 1986, como um desdobramento do trabalho do CTI (Centro de Trabalho Indigenista), e sua proposta consiste na capacitação de indígenas para operar as tecnologias de registro que possibilitem processos de autonomia e autodeterminação na produção do discurso fílmico a partir dos próprios realizadores indígenas. Para mais informações sobre o Vídeo nas Aldeias Cf. "Vídeo nas Aldeias: 25 anos" (2011) organizado por Ana Carvalho Ziller Araujo, Ernesto Carvalho e Vincent Carelli.

138 Como lembra Ribeiro (2007), no final da década 1970 e começo da década de 1980, Rouch promoveu "ateliers" de Cinema (em super8 sonoro) em Maputo, Moçambique (e antes disso em Portugal), visando instrumentalizar trabalhadores do Centro de Estudos de Comunicação da Universidade Eduardo Mondlane, para a realização de documentários. Estas iniciativas estão na gênese dos Ateliers Varan que depois se espalharam pelo mundo. Embora Vincent Carelli, fundador do Vídeo nas Aldeias, com seu notável autodidatismo, ateste ter se jogado em suas primeiras experiências audiovisuais - quando realizou seu documentário "A festa da moça", em 1987, entre os Nambiquara -, em uma espécie de "vídeo-transe", "sem jamais ter ouvido falar de Jean Rouch ou no Cinema Verdade" (ARAUJO, p. 46), é fato que o Vídeo nas Aldeias aproximou-se substancialmente do repertório teórico-metodológico do antropólogo francês, amplamente desenvolvido em seu Ateliers Varan. 
O xavante Divino Tserewahú, por exemplo, teve sua formação ainda muito jovem, a partir do "Vídeo nas Aldeias". Neste encontro, a ética pressuposta na Antropologia Partilhada, encontrou aquilo que Divino compreende, em sua língua e em sua cultura, como Iwaimrãmiwe, isto é, a necessidade prática na vida cotidiana de se reportar aos anciãos a fim de se buscar a aprovação - em processos de negociação ética e estética sobre a forma como se apresentam os rituais, experiências e vivencias do povo xavante, para o próprio povo xavante (auwé uptab) e para os não indígenas (waradzu). A Antropologia Partilhada, portanto, encontra lastro também no cotidiano, ou como diria Bairon (2014), no "senso comum cultural" do povo xavante, habitante do cerrado brasileiro.

No tocante a uma aproximação entre a Antropologia Partilhada e uma potencial reticularidade, vemos em "Martírio", de 2016, o último filme dirigido por Vincent Carelli (coordenador da ONG), um exemplo substancial e inspirador de um uso pleno do potencial de engajamento e articulação a partir das redes. 0 filme, que trata dos processos de retomada dos territórios tradicionais (tekoha) dos guarani-kaiowá, no estado do Mato Grosso do Sul, e consequentemente toda violência (institucional, física, política, etc) sofrida historicamente por este povo, foi em grande parte financiado via crowdfunding, isto é, a partir de um financiamento coletivo. Centenas de pessoas de diversos estados brasileiros e do exterior solidarizaram-se com o projeto e contribuíram financeiramente com pequenas quantias que, em grande parte, ajudaram a subsidiar o longa-metragem. Dos oitenta mil reais que a produção almejava para a realização do filme, a campanha arrecadou um total de quase oitenta e seis mil, atingindo $107 \%$ da meta. 


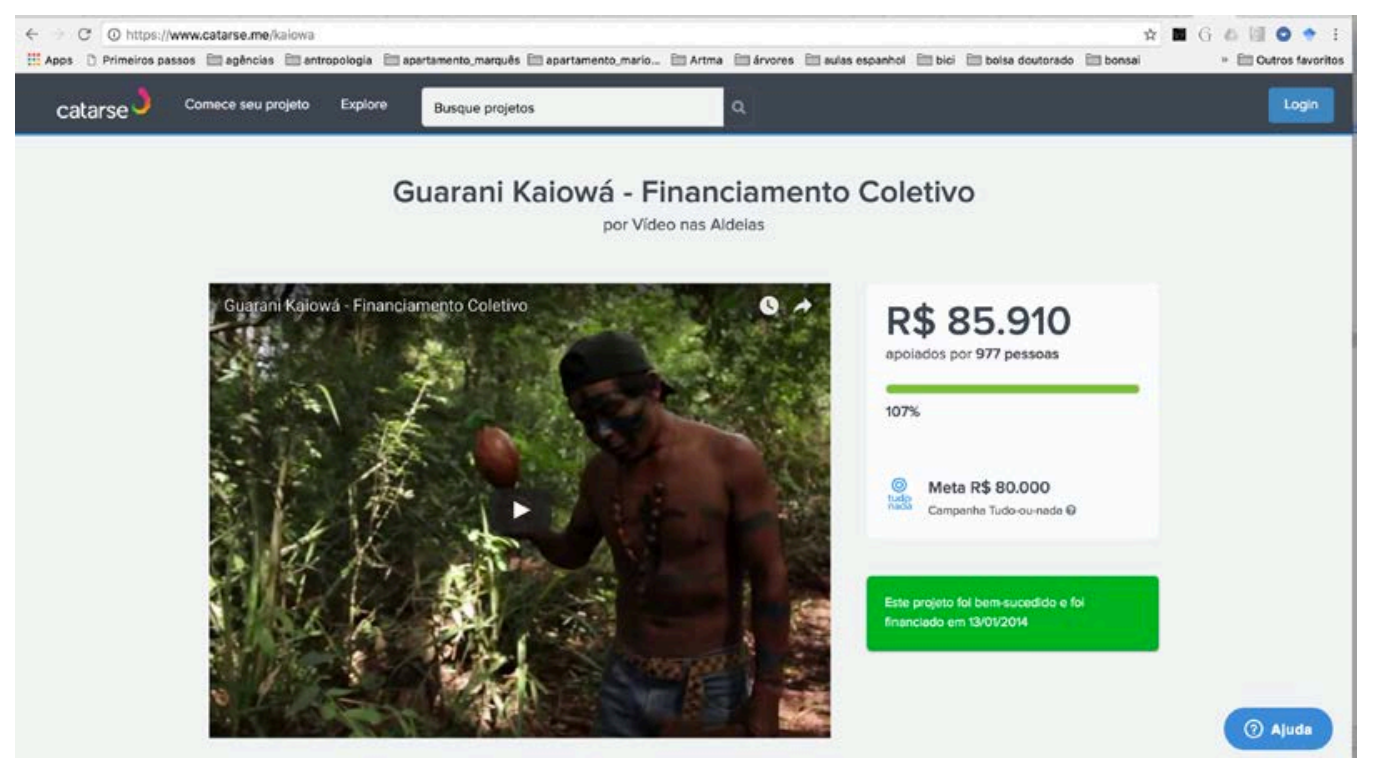

fig.20 - Página do financiamento coletivo do filme "Martírio", no Catarse.

As assembleias guarani-kaiowá, a partir das chamadas Aty Guassu (grandes assembleias), vinham reunindo-se desde o final da década 1970, a fim de articular estratégias de "re-existência", dadas as frequentes ofensivas do estado e de grupos paramilitares (organizados por fazendeiros e posseiros). Este trabalho de décadas persistiu distante dos centros urbanos e dos holofotes midiáticos, a despeito da contínua violência com que eram atacados. Somente recentemente é que a luta dos guaranikaiowá ganhou uma grande visibilidade e repercussão, sobretudo desde 2012, quando se deu a publicação da carta da comunidade de "Pyelito Kue"139, que anunciava a possibilidade de um suicídio coletivo, haja vista que nada mais restava a este povo, historicamente perseguido e que, já sem esperanças, desejava assim morrer em sua terra. A solidariedade se estendeu às redes sociais, quando milhares de usuários da rede facebook passaram a adotar em seus nomes o etnômio Guarani-kaiowá. Vincent Carelli, no entanto, também vinha trabalhando esporadicamente com os kaiowá desde a década de 1980 e presenciou todo tipo de violência a qual este povo fora submetido. Em suas palavras: “'Agora com essa tragédia com os Guarani Kaiowa, é preciso fazer algo, e o cinema é uma ferramenta poderosa, aprendi isso com Corumbiara. Não é por gosto que tenho tratado do tema da violência contra os índios, é por imposição dos acontecimentos" (MILANEZ, 2016).

139 VER Apêndice A. 
Ao mesmo tempo em que a campanha corria (centrada no site de financiamento colaborativo "Catarse"), pequenos vídeos eram postados nas redes sociais vinculadas ao "Vídeo nas Aldeias", a fim de despertar a percepção de potenciais "financiadores" que, por sua vez, também compartilhavam a campanha em suas redes. 0 filme, por fim, é a segunda parte de uma trilogia sobre a questão indígena no Brasil, iniciada por “Corumbiara” (de 2009) e que, deverá ser finalizada com “Adeus, Capitão”, a propósito dos gavião do Pará e, em especial, o líder Krokenum (conhecido também por Capitão).

Neste caso singular, temos o exemplo de um filme que soube fazer um uso da reticularidade a partir de uma articulação entre ambiências, utilizando-se para tanto diferentes redes. Embora aqui não configure-se propriamente como um exemplo da "reticularidade fílmica", trata-se no entanto de um processo reticular-digital com propósitos fílmicos.

De volta à Rouch, em 1995 ele antevia as possibilidades da Antropologia Partilhada na relação com as inovações tecnológicas e a facilitação das formas de produção audiovisual,

And tomorrow? ... Tomorrow will be the day of self-regulating color videotape, of automatic video-editing, of the instant replay of the recorded picture ("immediate feedback"). The dreams of Vertov and Flaherty will be combined into a mechanical cine-eyeear which is such a participating camera that it will pass automatically into the hands of those who were, up to now, always been in front of it. The anthropologist will no longer monopoliza the observation of things; Instead, both he and his culture will be observed and recorded. In this way ethnographic film will help us to "share" anthropology...140 (ROUCH, 1995, p. 98)

Segundo Ruby (2007, p.12) ${ }^{141}$, o futuro da Antropologia Visual passará pelo "desenvolvimento de etnografias digitais interativas". Esta perspectiva, embora ainda desenvolva-se de modo parcimonioso no meio científico, pode no entanto ser cada vez

\footnotetext{
140 Tradução nossa: "E amanhã? ... Amanhã será o dia do auto-ajuste do vídeo em cores, de edição automática do vídeo, da repetição instantânea da imagem gravada ("feedback imediato"). Os sonhos de Vertov e Flaherty serão combinados em um cine-olho-ouvido mecânico que é uma câmera tão participante que passará automaticamente nas mãos daqueles que, até agora, sempre estiveram na frente dela. 0 antropólogo não monopolizará mais a observação das coisas; Em vez disso, tanto ele como sua cultura serão observados e registrados. Desta forma, o filme etnográfico nos ajudará a "compartilhar" a antropologia".

${ }^{141}$ RUBY, Jay. Los últimos 20 años de Antropología visual - una revisión crítica. Revista Chilena de Antropología Visual. número 9. Santiago. junho 2007. Disponível em http://www.rchav.cl/imagenes9/imprimr/ruby.pdf Acesso em: 15/04/2016
} 
mais notada nas interfaces com o cinema interativo e as novas medias. Outrossim, em um percurso que compreenda, pois, a Antropologia Partilhada em contexto digital, estamos diante de possibilidades inclusivas que ensejam o desenvolvimento de um modo integralmente participativo, como antevisto por Rouch, na construção de ambiências em reticularidade fílmica. Como pontua Gaudenzi (2013),

Beside co-authoring and co-producing there is another way to include the participant in the production of an interactive documentary: co-initiating content. This happens when the collaboration is placed in the pre-production phase of both the video material and the interactive artefact. In this case the participant is not a "user" of a launched interactive artefact but a potential "subject" of a project in its shaping. This type of collaboration come neither from the peer-sourcing of open software, nor from the crowdsourcing of Wikipedia and YouTube, but rather from the participative school of Cinema Vérité of the 1960 's and it is often linked to a social activist cause. ${ }^{142}$ (p. 203)

Os documentário e as etnografias em reticularidade fílmica podem propiciar, portanto, a tríade: co-criação, co-produção e co-inicialização. A noção de feedback de Rouch é novamente ampliada e passamos portanto ao paradigma da Produção Partilhada em reticularidade fílmica.

\section{A pedagogia griô e a produção partilhada}

Os primeiros arquivos ou bibliotecas do mundo foram o cérebro dos homens. Antes de colocar seus pensamentos no papel, o escritor ou o estudioso mantém um diálogo secreto consigo mesmo. Antes de escrever um relato, o homem recorda os fatos tal como lhe foram narrados ou, no caso de experiência própria, tal como ele mesmo os narra. (HAMPATE BÁ, 2010 p. 168) (143 $^{14}$

142 Tradução nossa: "Além da co-autoria e co-produção, há outra maneira de incluir o participante na produção de um documentário interativo: co-iniciar o conteúdo. Isso acontece quando a colaboração é colocada na fase de pré-produção do material de vídeo e da ambiência interativo. Neste caso, o participante não é um "usuário" de uma ambiência interativa, mas um "sujeito" potencial de um projeto na sua formação. Este tipo de colaboração não vem nem do peer-sourcing de software aberto, nem do crowdsourcing da Wikipedia e YouTube, mas da escola participativa do Cinema Vérité da década de 1960 e muitas vezes está ligada ao ativismo em causas sociais."

${ }^{143}$ História geral da África, I: Metodologia e pré-história da África / editado por Joseph Ki-Zerbo. - 2.ed. rev. - Brasília : UNESCO, 2010. 992 p. 
como uma roda ioruba nú rio da vida, como nús nascemos. grito de gente que nasce da gente nascente. oba, O, baobá, que nasce griô uma sumaúma na Amazônia é como 0 xapiri que segura a queda do céu. rãri karajá é parte bicho arara, boto é parte gente. tambor do coração de griô semente de terra, de vida, de gentes índio com coração de flauta, de flecha,

$$
\begin{array}{r}
0 \\
\text { io } \\
\text { rio } \\
\text { griô } \\
\text { griot }
\end{array}
$$

Certa vez o amigo documentarista Rodrigo Arajeju (informação verbal) ${ }^{144}$ contou estar presente a um encontro onde, durante uma roda de conversa, um sujeito decidiu perguntar a Álvaro Tukano, tradicional liderança Tukano do Alto do Rio Negro - AM, o que era exatamente "ser índio". Álvaro então teria respondido que "ser índio, é como ser um músico, dançante, poeta, mágico, tudo ao mesmo tempo", ou seja, que "ser índio" é como "ser híbrido". Algo como um "perder-se" em uma ciranda perspectivista e vivenciar cotidianamente diversificadas possibilidades de experiências estéticas. Apesar da aparência sucintamente genérica e até, em alguma medida, folclorizante, a fala de Álvaro traduz a percepção de um sujeito que não logrou o estado limítrofe e estanque dos compartimentos de saber da ciência moderna. Concordando com Latour (1994), poderíamos dizer, portanto, que ser índio, jamais foi "ser moderno".

Este "ser índio", assim definido por Alvaro Tukano, remete-nos à perspectiva do "ser griô" e, mais apropriadamente, à aproximação que propõem Lilian Pacheco e Marcio Caires do griô africano, sujeito síntese de saberes, com os mestres de tradição oral das diversas culturas que consistem o "povo novo" brasileiro. Como definimos anteriormente,

O saber do Mestre Griô é um nome-síntese de trajetórias agregadoras, múltiplas, híbridas, mestiças e inovadoras do povo brasileiro. 0 saber do Mestre Griô não representa uma unidade

${ }^{144}$ Na ocasião da exibição de seu filme "Índios no Poder" (2015) no "cine-clube Kinoks", na Universidade Anhembi Morumbi, em agosto de 2016. 
cultural, ao contrário, expressa a diversidade de um povo que aprendeu a construir sua identidade com o Outro. 0 saber do Mestre Griô é um nome que age como uma metáfora de que o "eu" é sempre o resultado do diálogo com o "outro", ou melhor, o eu é também o outro. 145

Na tradição da África saariana, mais especificamente das regiões do Mali e da Guiné, os griots ${ }^{146}$ a partir da oralidade possuíam “[...] a função de transmitir a tradição histórica: eram os cronistas, genealogistas, arautos, aqueles que dominavam a palavra, sendo, por vezes, excelentes poetas; mais tarde passaram também a ser músicos e a percorrer grandes distâncias, visitando povoações onde tocavam e falavam do passado (COSTA, LIMA, 2015, p.223). Pacheco (2015), compreende nesta dimensão, um conceitosíntese da diversidade, e propõe pensar a partir dele uma articulação entre os diversos saberes e os processos de educação formal. É nesta espiral que surge portanto a Pedagogia Griô.

A pedagogia griô enfatiza a ancestralidade da oralidade - onde os saberes necessariamente transcendem as peles de papel $^{147}$, e na dimensão ritual, corporal, a pele é media e a roda é seu dispositivo - que fundamenta certos modos de vida em comunidade. Sua proposição, portanto, mostra-se afeita a lidar com os saberes destas mesmas diversificadas oralidades, onde os interlocutores e autores são, por excelência, griôs de saber notório, de uns trans-saber, que atravessa como flecha, superfícies rígidas, estratificadas camadas de um saber vernáculo, moldado, estanque, criando assim reticularidades. Lilian Pacheco (2015) compreende que esta

é uma pedagogia da vivência de rituais afetivos e culturais que facilitam o diálogo entre as idades, a escola e a comunidade, grupos étnico-raciais, tradição e contemporaneidade, interagindo e mediando saberes ancestrais de tradição oral e as ciências formais, por meio do reconhecimento do lugar social, político e econômico dos mestres Griôs na educação, para a elaboração do

145 BAIRON, BATISTELLA, LAZANEO, 2015, p.249.

${ }^{146}$ A despeito das outras interpretações possíveis, Niane (1982) considera o termo griot como sendo um termo de origem francesa. De acordo com Hampaté Ba (2010), os griots pertencem às castas dos "Dieli", sendo assim também conhecidos.

147 Davi Kopenawa, em "A queda do céu" (ALBERT, KOPENAWA, 2015), explica que assim os yanomanis reportam-se às páginas dos livros escritos pelos brancos, seriam elas "peles de papel". "As páginas escritas e, de modo mais geral, os documentos impressos contendo ilustrações (revistas, livros, jornais) de utupa siki ("peles de imagens"). [...] Referem-se à escrita com termos que descrevem certos motivos de sua pintura corporal: oni (série de traços curtos), turu (conjunto de pontos grossos) e yãkano (sinusoides). Escrever é, assim, "desenhar traços", "desenhar pontos" ou "desenhar sinusoides", e a escrita, $t$ ë ã oni, é um desenho de palavras." (ALBERT, KOPENAWA, p.610, 2015) 
conhecimento e de um projeto de vida que tem como foco a expressão da identidade, o vínculo com a ancestralidade e a celebração da vida." (p. 66)

Podemos compreender que a Pedagogia Griô fundamenta-se, de modo geral, em dois pilares básicos. A Identidade, com ênfase em sua ontogênese e a ancestralidade, por sua vez, na filogênese. A identidade circunscreve o ser no âmago de sua diferença, ou seja, o sujeito "é" porque reconhece-se diferente, ou melhor, em diferença. É, pois, a diferença aquilo que substancia e identifica, que portanto dota de especificidade. A ancestralidade é tratada em uma dimensão de uma reconexão, um devir-comunal, “transcendente a um território, família-comunidade, um povo” (PACHECO, 2015, p.86), enquanto filogênese, entre o ser e o que lhe antecede, suas tradições, seus saberes comuns que, por sua vez, herdam os modos de vida e compreensões comunitárias, dos ambientes onde se inserem, onde sua história, pluralmente, se edifica.

No âmbito da pedagogia griô, esta compreensão imerge no interior dos binômios hegemônico x contra-hegemônico ${ }^{148}$, incluído x excluído, como um produto resultante deste incessante conflito, em espiral. Assim,

A Pedagogia Griô nasce destas relações entre o incluído e o excluído, deste campo aberto e infinito de dicotomias óbvias, contradições veladas, erros epistemológicos. E o foco de reflexão se dá nas dualidades propostas pelo pensamento da ciência e da cultura moderna, entre vivência e consciência, mente e corpo, popular e erudito, emoção e razão, instituição e comunidade, tradição e contemporaneidade, mito e realidade, identidade e ancestralidade, eu o outro e a totalidade." (PACHECO, p.38)

Identidade e ancestralidade, emergem de uma dialética entre o ser, em sua singularidade, e o ser em sua pluralidade, seu senso communis, seu saber social ou seu senso comum cultural, constituindo princípios fundamentais para um efetivo processo de reconhecimento, onde as vivências oportunamente principiam-se com o questionamento fundamental: - Quem sou? Portanto: - Quem somos? Identidade e ancestralidade seriam os polos a nortear, ou melhor, a auxiliar na composição de uma "epistemologia do sul" - para ficarmos em uma oportuna sugestão geográfica -, traduzindo na produção de conhecimento as experiências estéticas da tradição oral.

As mestras e mestres são, portanto o alicerce reticular - se assim podemos dizer ,

148 Pacheco (2015, p.36) situa, por exemplo, a Produção Partilhada do Conhecimento enquanto um parâmetro de uma cultura contra-hegemônica, no âmbito do que denomina "Educação comunitária". 
o fio condutor dos saberes griôs, os protagonistas destes que são os bancos de dados do "senso comum cultural". Compreendem o elo erigido com base na ancestralidade e na identidade em que,

O saber do Mestre Griô é a própria experiência enquanto produtora do texto, pois toda aproximação maior com as manifestações culturais se origina no homem ordinário e se revela no momento em que este se torna o narrador, exatamente porque é dele que se define o lugar (comum) do discurso e do espaço (anônimo) de seu desenvolvimento. ${ }^{149}$

$\mathrm{Na}$ metodologia da Pedagogia Griô, é também fundamental o papel da interlocução entre as mestras e mestres da tradição oral e os processos de produção e partilha de seus conhecimentos. Nesta inter-relação atua o griô-aprendiz, que representa

[...] mais do que um lugar social e político de mediação. Ele é antes de tudo, um arquétipo, ou seja, um personagem mítico, um encantado de alguém que doa sua corporeidade como lugar de registro, biblioteca viva e transmissão dos saberes e fazeres de comunidades, grupos e povos de tradição oral, garantindo assim a continuidade da rede de transmissão oral. (PACHECO, 2015, p. 73)

Nas pesquisas em Produção Partilhada que aqui relatamos, compreendemos que aqueles que poderiam ser assim chamados, griôs-aprendizes, atuam sobremaneira na interface da transmissão dos saberes destas bibliotecas vivas, atualizando-as a partir de processos que envolvem, principalmente, a produção audiovisual. É assim, por exemplo, que Juanahú Iny, entre os iny (karajá), busca registrar a memória viva dos velhos a propósito de seus rituais e costumes. A participação dos griôs aprendizes neste processo partilhado é fundamental, pois seu lugar de pertencimento legitima uma abordagem coerente, em contextos onde recorrentemente

alguns grupos artísticos e de pesquisa copiam ou registram (por meio escrito, fotográfico ou audiovisual) práticas e saberes de tradição oral compreendendo que estão executando um trabalho de resgate da oralidade. Ao pretender-se resgatar algo, cria-se o papel daquele que resgata e daquele que é resgatado. Só que o papel de resgatado é o de objeto do registro, do conhecimento e da ação. (PACHECO, 2015, p.81) 150

149 BAIRON, BATISTELLA, LAZANEO, 2015, p.261.

150 Pacheco, propõe ainda outra importante reflexão tendo como base a entrevista enquanto método. Segundo ela: "A entrevista pode ser oral, mas cria a relação sujeito objeto que não pode ser considerada dialógica, então, não é fundada na oralidade que, mesmo no silêncio, cria sentidos profundos em relação ao poder da escuta e da palavra. Um registro fundado na 
Esta reflexão faz-se necessária sobretudo em um contexto onde as tecnologias audiovisuais de registro tornam-se cada vez mais comuns nas práticas dos pesquisadores em campo. No entanto quando são encaradas sob um viés instrumental, aproximam-se de forma semelhante ao uso do texto científico, ou seja, também configuram-se como formas de produzir o conhecimento com base na clássica divisão entre o sujeito do conhecimento e o "sujeitado" a este conhecimento (seu objeto). Quando porém, investimos coletivamente o esforço em uma direção dialógica, na criação de produtos que articulem saberes distintos em ambiências heterárquicas,

0 resultado é que a produção de conhecimento passa a ser produto de um conjunto reticular de conversações e convivências, equiparando conceitos e estéticas acadêmicas à oralidade e corporeidade do estar no mundo do senso comum cultural. Trata-se da soma de dois modos de vida já arcaicos: de um lado, o acadêmico que não olha mais para as comunidades como "fontes documentais", mas como parceiros; do outro lado, o saber centenário do conhecimento, corporificado no senso comum, que é apresentado por meio da vitalidade de suas dimensões epistemológicas já acostumada a domesticar as técnicas. (BAIRON, 2014, p.69)

Destarte, interessa-nos nas relações da Pedagogia Griô com a Produção Partilhada, destacar o encontro entre o saber do mestre griô, a comunidade que acolhe esta horizontalidade de sentidos e a proposição dialógica que enfrenta, pois, a habitual rejeição do cientificismo aos saberes deste senso comum. Isto é, a proposição dialógica que busca inserir os saberes das vivências da corpo-oralidade na educação formal.

Não desvalorizamos a possibilidade da presença do saberes da tradição oral, em contextos acadêmicos, a partir do audiovisual, ou mesmo a partir da transcrição literária de suas narrativas, ou mesmo, de pesquisas que etnografam rituais, compreensões das singularidades culturais dos povos, etc. Entretanto, enquanto os saberes da não cientificidade permanecerem subsumidos, controlados por uma episteme hierárquica (que é quem os dota de sentidos) e os transforma em livros e filmes de intransponíveis autorias que não lhes pertencem, estaremos a desperdiçar a inifnitude sígnica da experiência estética, o diálogo entre epistemologias diversas, a circularidade da

oralidade, tem a linguagem de registro que é a vivência, o movimento, a dança, o canto, a corporeidade afetiva, a memória oral, o diálogo. É assim que ao longo dos séculos a tradição oral garante a sua transmissão oral de geração em geração. Um registro escrito tem sua função de valorização, mas não significa uma prática fundada na oralidade, nem que garante sua transmissão" (p. 81). 
socialização do conhecimento acadêmico nas comunidades, a socialização do conhecimento das comunidades na academia e o encontro de ambos em ambientes reticulares de gestão partilhada.

Em 2012, buscamos durante uma semana aproximar esta diversidade epistêmica na proposição de um curso de extensão vivencial, intitulado "Pedagogia Griô e Produção Partilhada do Conhecimento"151. Durante esta semana partilharam seus saberes mestras e mestres de tradição oral (representantes de comunidades indígenas, territórios quilombolas, etc), griôs aprendizes, educadores, alunos das diferentes escolas e departamentos e demais interessados. Este encontro na Universidade de São Paulo inaugurou um processo fértil de interlocução com estes saberes outros que, na condição de sua notoriedade, conduziram as "aulas" - aqui um conceito insuficiente - isto é, as vivências da corpo-oralidade

Na perspectiva de Lilian Pacheco (2015, p.47) que endossamos, temos hoje à disposição novas perspectivas epistemologicamente redefinidoras que, para além do próprio campo, demandam dos sujeitos conexões, articulações, composições múltiplas, em partilha.

As bases sociais da nova tendência da educação não se concentram em pesquisas de autores isolados e acadêmicos, mas na espontaneidade criativa e vivencial de autores, grupos de pesquisa e estudo, grupos de ação comunitária, movimentos sociais e culturais que se reencantam e produzem de forma compartilhada, interdisciplinar, transdisciplinar e em rede.

1510 curso foi oferecido no prédio de Geografia da Faculdade de Filosofia, Letras e Ciências Humanas da Universidade de São Paulo, de 05/12 a 10/12 de 2012, e organizado por uma rede de professores da Escola de Comunicações e Artes e da FFLCH (USP), da Universidade Griô, da Universidade Livre Fora do Eixo, do CEACA (Centro de Estudos da Capoeira) e do Ponto de Cultura Nina Griô. Dois pequenos vídeos resumem o que consistiu essa semana: "Curso Pedagogia Griô e Produção Partilhada na USP" que pode ser acessado em: https://www.youtube.com/watch?v= Z7hN4dGWGo e "A Universidade e a Pedagogia Griô", que pode ser acessado em: https://www.youtube.com/watch?v=TCSiE FH5Jo 


\section{Pesquisa-ação e a produção partilhada}

ejetar

0 sub jeito

do sujeito

desobedece

o objetivo.

0 jeito

do objeto,

então,

é virar

subjetivo.

Como temos abordado, o saber acadêmico institucionalizado, subsidiado pela consolidação da ciência moderna, vê-se diante de uma constante crise de paradigmas. Diante disso, é preciso pois que a ciência, ou mais propriamente o fazer científico, esteja afeto a uma (re)configuração de suas lógicas, de seus modos de operar, de seus pressupostos metodológicos estanques, em que a transdisciplinaridade não possa mais ser prescindida, isto é, que se proponha propriamente um pacto. Um pacto da ciência que leve, consequentemente, a uma ciência do pacto. Se há um objetivo de se pactuar por alguma transformação, há portanto que se produzir epistemologias desta mesma transformação. É preciso pois que as ciências múltiplas reafirmem pactos, tanto entre si quanto entre o mundo das culturas vivas, dos saberes populares, do saber griô, ancestral - negligenciado pela educação formal. Do eu, privilegiado, aos nós partilhado. Nós que tecem diálogos disciplinares entre aqueles que habitam o cotidiano acadêmico e sua estrutura enrijecida, bem como os nós que superem a dicotomia saber científico/senso comum, ou melhor, dos saberes locais e plurais.

Acreditamos que as proposições que englobam uma Produção Partilhada do Conhecimento, utilizando como substrato pontos de convergência com a metodologia da pesquisa-ação (THIOLLENT, 2011), vão ao encontro da necessidade do desenvolvimento de pesquisas empíricas como condição, sine qua non, para sua sustentação conceitual. Embora, via de regra, em uma pesquisa convencional faz-se necessária a elaboração de um sistema de hipóteses, a

[...] pesquisa-ação seria um procedimento diferente, capaz de explorar as situações e problemas para os quais é difícil, senão impossível, formular hipóteses prévias e relacionadas com um pequeno número de 
variáveis precisas, isoláveis e quantificáveis. É o caso da pesquisa implicando interação de grupos sociais no qual se manifestam muitas variáveis imprecisas dentro de um contexto em permanente movimento. (THIOLLENT, p. 40)

A despeito de concordarmos com a dificuldade da construção de um rígido sistema de hipóteses específicas, sobretudo considerando o pleno dinamismo de uma pesquisa-ação, gostaríamos, contudo, lembrar de hipóteses gerais que tem norteado-nos em pesquisas de Produção Partilhada: 1. No contexto da "ciência pós-moderna” (Santos, 2002), é possível proporcionarmos um processo de “dupla ruptura epistemológica” em que a hipermídia, atuando enquanto uma comunidade de comunicação, estabeleça-se como um local/ambiente de encontro entre um saber científico (formal) e os saberes do senso comum. 2. A multilinearidade de um filme em reticularidade, em que suas possibilidades de navegação sejam negociadas entre os atores e autores da pesquisa, aproxima e possibilita que as distintas formas de compreensão de mundo reconheçam-se em seu cotidiano, isto é na expressividade da experiência estética.

A partir da hipermídia, defendemos a possibilidade de expansão do diálogo no contexto da produção científica, em que novas possibilidades interdisciplinares, de produtos reticulares, de hibridismo de linguagens (sons, textos, imagens) possam, ser mais exploradas.

Boaventura de Souza Santos (2002), compreende que uma ciência pós-moderna deve zelar pelo exercício do retorno daquilo que é produzido no contexto científico para o senso comum ${ }^{152}$. Neste sentido, encontramos na pesquisa-ação um aporte que se apresenta enquanto interface de um caminho que, nesta pesquisa, tem início na

\footnotetext{
152 Segundo o autor em sua obra "Introdução a uma ciência pós moderna" (2002), a metodologia racionalista - amplamente calcado no contexto da ruptura epistemológica em que "objetos" do senso comum necessitam passar por um ruptura para que elevem-se à condição de cientificidade - deve, no contexto pós-moderno, repensar-se de forma a possibilitar que a primeira ruptura que permitiu a estruturação da produção de conhecimento, passe por uma nova ruptura (a chamada dupla ruptura epistemológica) que proporcione seu retorno ao senso comum. Nas palavras do autor: "[...] a verdade é que se a primeira ruptura torna possível a teoria crítica, só a segunda ruptura torna possível que a crítica seja prática. Uma teoria crítica não se torna prática pelo mero efeito de uma qualquer concretização. É necessário que tal concretização ocorra criticamente, ou seja, segundo um critério; este na concepção que aqui defendo, é o da superação da distinção entre ciência e senso comum e da transformação de ambos numa nova forma de conhecimento, simultaneamente mais reflexivo e mais prático, mais democrático, e mais emancipador do que qualquer deles em separado." (ibid, p.85-86)
} 
experiência estética, isto é, considerando-a como a expressividade epistemológica de um contexto de tradição oral.

Trazemos aqui como referência seis importantes passos definidos por Thiollent (2011) sobre a pesquisa ação:

“a) há uma ampla e explícita interação entre os pesquisadores e pessoas implicadas na situação investigada" (ibid, p. 22)

Na proposição da Produção Partilhada, os fluxos de interação são parte fundamental do processo de produção do conhecimento e da reflexividade. Não é desejável, pois, a autoria (privilegiada) e unívoca do pesquisador, senão um jogo em que se produz (conjuntamente) e depois se convida à reflexão e, se possível (e desejável), se produz novamente sobre a reflexão. Compreendemos, de acordo com Boaventura Souza Santos (2002), que:

A ciência torna-se reflexiva sempre que a relação "normal" sujeito-objetcto é suspensa e, em seu lugar, o sujeito epistêmico analisa a relação consigo próprio, enquanto sujeito empírico, com os instrumentos científicos de que se serve, com a comunidade científica em que se integra e, em última instância, com a sociedade nacional de que é membro. (p. 87)

Neste caso, enquanto premissa epistemológica, interessa primeiro a análise do sujeito empírico em seu entorno, no impacto da Produção Partilhada em seu cotidiano, em seu contexto local, para depois consequentemente com a comunidade científica, e assim por diante.

Entretanto, refletimos sobre uma etapa metodológica comum, tanto à Produção Partilhada, quanto à Pedagogia Griô, e a Pesquisa-ação, que consiste efetivamente no princípio do acolhimento. Notadamente a aproximação com qualquer comunidade, seja urbana ou rural, não se dá nem fortuitamente e nem de uma hora para outra, e o trabalho de campo configura-se como uma etapa crucial, ou melhor dizendo, o trabalho de campo é o cerne do próprio trabalho.

O subsídio à análise das relações entre universidade e comunidade, expressa-se, consequentemente, nas relações entre o(s) pesquisador(es) e os interlocutores das comunidades, além da construção de produtos que servem a ambos os propósitos (tanto acadêmicos bem como de suas comunidades de origem). Portanto, pressupor a 
realização de trabalhos de campo, em alguma medida etnográficos (mesmo que autoetnográficos), constitui um problema à priori. Muitas vezes criam-se expectativas de ambos os lados que não podem ser imediatamente atendidas, bem como em outras oportunidades parece reinar uma ausência de "motivos chave"153, em que a comunidade esteja afeita a receber interlocutores acadêmicos, para colaborar neste percurso.

Na pesquisa de mestrado, por exemplo, passamos pela situação de empreender uma viagem de distância considerável - contando com inúmeras dificuldades logísticas a uma aldeia bororo, onde o objetivo seria realizar um documentário junto de Paulinho Kadojeba (realizador bororo) a propósito do tradicional ritual fúnebre de seu povo. Porém, somente ao chegar à comunidade, é que fomos informados de que, por motivos diversos, os registros não seriam permitidos. Embora isso tenha proporcionado, à época, uma reflexão bastante valiosa e oportuna, procuramos agora, de qualquer modo, estarmos precavidos de que situações como esta voltem a ocorrer ${ }^{154}$.

Nesta oportunidade, o que seria um primeiro princípio da Produção Partilhada o acolhimento - não logrou-se possível, pois, dentre outros motivos, avaliamos que a relação anterior necessária com a comunidade não havia sido suficientemente projetada. Estávamos em campo Paulinho Kadojeba e eu. Eu, enquanto pesquisador de uma universidade de São Paulo absolutamente distante da vida cotidiana daquela população. Paulinho, por sua vez, embora sendo um bororo e possuindo parentes ${ }^{155}$ na aldeia, vinha de outra aldeia, Meruri, distante da aldeia Gomes Carneiro.

153 Consideramos que os "motivos chave" para a realização de trabalhos de campo, como no presente caso (objetivando a realização de produtos audiovisuais em produção partilhada), normalmente estão associados às datas festivas, aos rituais, aos momentos de coesão da comunidade onde a importância de um registro criterioso dos eventos é sempre um fato ressaltado e considerado importante por todos.

${ }^{154}$ Como veremos adiante, o processo de produção partilhada que gerou a presente pesquisa, foi fruto de convites frequentes por parte de Juanahú Iny e, de algum modo, de sua comunidade.

155 Enfatizamos aqui que os parentes de Paulinho que viviam na aldeia possuíam com ele um grau de parentesco direto, como pai, tia e irmãs, portanto uma interlocução positiva. Consideramos esta uma informação importante, uma vez que é comum notar que os indígenas brasileiros das mais diversas etnias, em geral, reportam-se uns aos outros como "parentes", considerando-se, de um modo simbólico, parte de uma mesma família. 


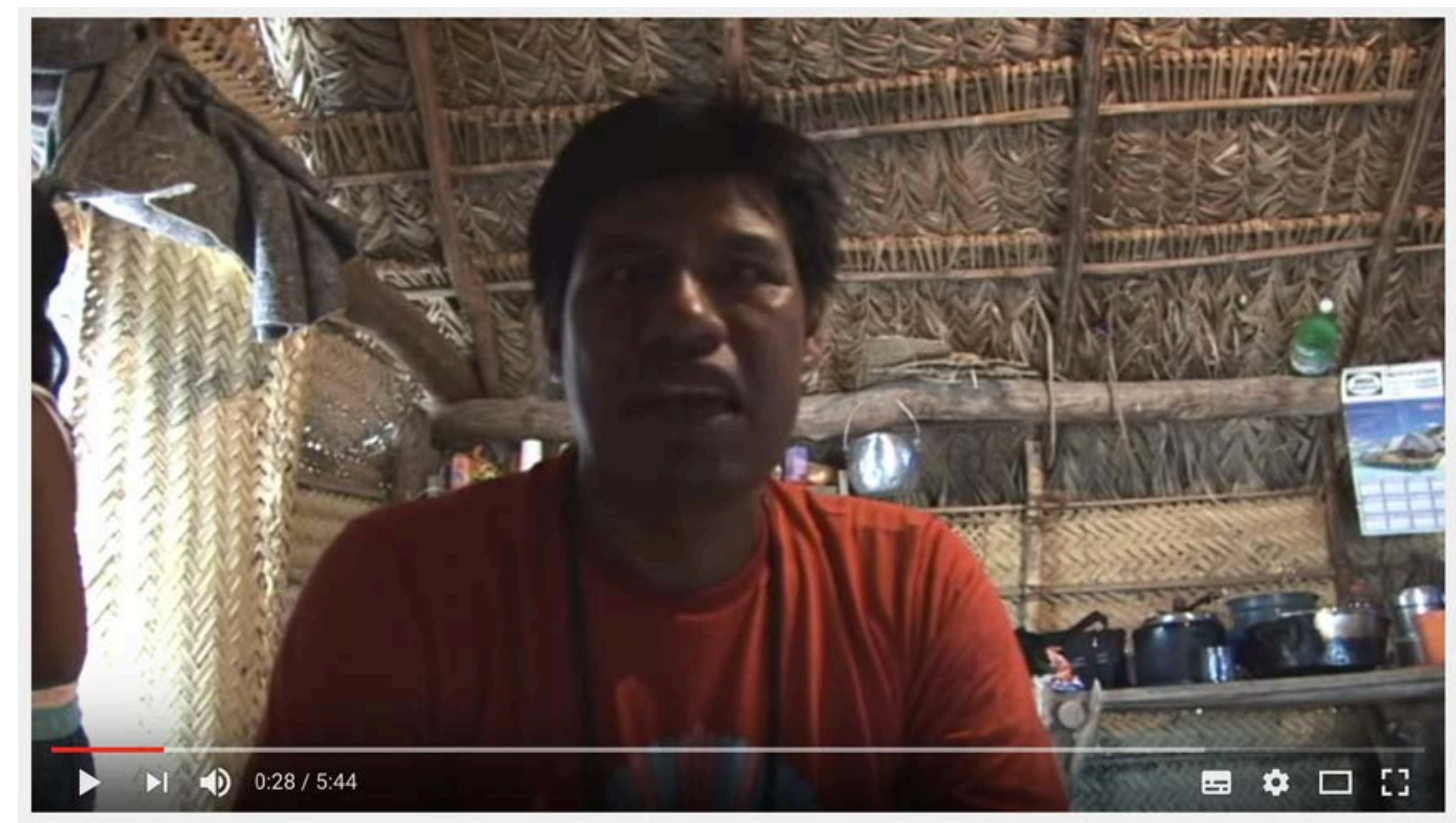

"Quando o índio mesmo filma a sua cultura, o vídeo é um espelho" Paulinho Ecerae Kadojeba

8. CEDIPP - DIVERSITAS FFLCH - ECA / USP - LabAV/U...

fig. 21 - Paulinho Ecerae Kadojeba reflete sobre a não realização do documentário sobre o ritual fúnebre bororo. ${ }^{156}$.

Em todo caso, consideramos esta etapa inicial, do acolhimento, como aquela em que o pesquisador, a partir de redes que estabeleçam uma comunicação frequente e heterárquica, é convidado para um trabalho de campo. Entretanto, o pesquisador em campo, em processo de Produção Partilhada, tampouco chega a romper com a perspectiva exotópica (advinda de um lugar outro) e aqueles que se relacionam à pesquisa, enquanto sujeitos "transitantes", não ocupam tão somente papéis previamente estipulados (o binômio pesquisador x informante), senão reconfigurações dos mesmos.

“b) desta interação resulta a ordem de prioridade dos problemas a serem pesquisados e das soluções a serem encaminhadas sob forma de ação concreta"157

Como em experiências recentes em que pudemos participar de processos de Produção Partilhada do Conhecimento, a interação com as comunidades resultou na tomada de decisão das mesmas e na realização de filmes que retratam aspectos de seu

1560 vídeo está disponível no canal do youtube do Cedipp (Centro de Comunicação Digital e Pesquisa Partilhada) em: https://www.youtube.com/watch?v=rpCUsH8th0g\&t=28s

157 THIOLLENT, 2011 p. 22 
cotidiano, como a importante questão da demarcação de terras indígenas - explorada no curta-metragem bororo intitulado Jarudori (2013)158 - assim como questões de saúde como o alcoolismo e o diabetes (também trabalhados a partir da realização de curtasmetragens pelos xavante e bororo). No trabalho com os karajá, como veremos adiante, outros problema específicos passaram a surgir e a adentrar aos processos de produção partilhada.

“c) o objeto de investigação não é constituído pelas pessoas e sim pela situação social e pelos problemas de diferentes naturezas encontrados nesta situação" 159 .

Assim, é o entorno, as urgências do locus, e as experiências cotidianas e comunitárias que determinam as prioridades e os objetos a serem investigados.

“d) 0 objetivo da pesquisa-ação consiste em resolver ou, pelo menos, em esclarecer os problemas da situação observada"160.

A partir do audiovisual e da hipermídia pretende-se dar relevância aos problemas do local, isto é, aqueles identificados enquanto problemáticos pela população local e explanados por seus interlocutores. Se não a resolução, pretende-se ao menos propiciar uma elaboração conjunta no reconhecimento e na reflexão em torno dos problemas cotidianos revelados pelo encontro.

“e) Há, durante o processo, um acompanhamento das decisões, das ações e de toda a

158 Realizado no âmbito do Cedipp (Centro de Comunicação Digital e Produção Partilhada), a partir de oficinas em aldeias e na universidade. 0 vídeo "Jarudori - bororos, xavantes, estudantes e professores juntos - Produção Partilhada do Conhecimento", pode ser Acesso em: https://www.youtube.com/watch?v=VcKl81dC9rU . Os demais vídeos podem ser acessados no canal do youtube do Cedipp:

https://www.youtube.com/channel/UCk DhOUxbKkywCEF3JNrxDA . A luta pela demarcação da Terra Indígena Jarudori, vem sendo realizada pelos bororo há décadas. Originalmente demarcada pelo Marechal Rondon, em 1912, a T.I possuía aproximadamente 100 mil hectares. Ao longo do século XX, tanto posseiros como o estado apropriaram-se da maior parte destas terras, restando aos bororo uma porção de 4.706 hectares ainda repleta de invasões. A propósito do histórico da T.I Jarudori, Cf: BARROS, Edna Pina; BORDIGNON, Mario. Jarudori: Terra Indígena invadida. 2009, disponível em: http://static.recantodasletras.com.br/arquivos/2613032.pdf?1289730528 . Acesso em: $10 / 10 / 2016$.

159 THIOLLENT, 2011 p. 22

160 Op. cit. 
atividade intencional dos atores da situação"161.

A comunidade apropria-se da pesquisa e elabora uma espécie de curadoria, a partir de seus griôs aprendizes, que acompanha e legitima o processo. Como na experiência de realização do documentário karajá "Berahatxi-rbi Olodu Mahadú - 0 povo que veio do fundo do rio" (LAZANEO, 2013), é o saber local que define a montagem fílmica, e os atores/interlocutores obedecem a esta dinâmica.

“f) A pesquisa não se limita a uma forma de ação (risco de ativismo): pretende-se aumentar o conhecimento dos pesquisadores e o conhecimento ou o 'nível de consciência' das pessoas e grupos considerados"162.

A proposição da Produção Partilhada instabiliza o lugar que, julga-se consuetudinariamente, seja o gerador do saber, isto é os ambientes de educação formal. Enquanto partilha pressupõe que sejam efetivas tanto a participação de pesquisadores no contexto dos saberes locais bem como a participação de interlocutores destas comunidades em atividades propriamente acadêmicas. Compreendemos assim que é essencialmente neste fluxo que se consolida uma epistemologia dialógica, que pode promover uma dupla ruptura, traduzindo-se em conhecimento (e não mero ativismo) e para a qual:

alguns aspectos da crítica ao sistema convencional da pesquisa científica (academicismo, dependência institucional, unilateralidade da interpretação etc.) são muito pertinentes. Mas isto não deve nos fazer abrir mão das ideias de ciência e racionalidade, sem as quais sempre há riscos de "recaídas" no irracionalismo que, tanto no passado como no presente, foi associado ao obscurantismo e às manipulações de toda ordem ${ }^{163}$.

Em diálogo com estas seis etapas, os procedimentos metodológicos que compreenderam os trabalhos in loco (que trataremos no próximo capítulo) pressupõem, por sua vez, as seguintes etapas (LAZANEO, 2012):

1. Aceitação e acolhimento por uma determinada comunidade.

\footnotetext{
161 THIOLLENT, 2011, p.23

162 Op. cit.

163 Ibid, p. 27.
} 
2. Partilha de saberes teóricos e técnicos, in loco, a partir de objetivos em comum.

3. Feedback comum: retorno e aprendizado sobre os saberes locais durante o trabalho de campo..

4. Feedback partilhado: convite aos interlocutores das comunidades à participação em atividades acadêmicas, no espaço acadêmico.

5. Devolução dos produtos audiovisuais, hipermidiáticos e da pesquisa às comunidades.

Estas cinco etapas subsidiam o desenvolvimento das atividades no horizonte da construção dialógica, universidade-comunidade, portanto na experiência com comunidades que encontram-se distantes do contexto acadêmico, como aproximação com o senso comum por meio dos produtos audiovisuais, hipermidiáticos, em reticularidade fílmica a serem produzidos de forma partilhada. 


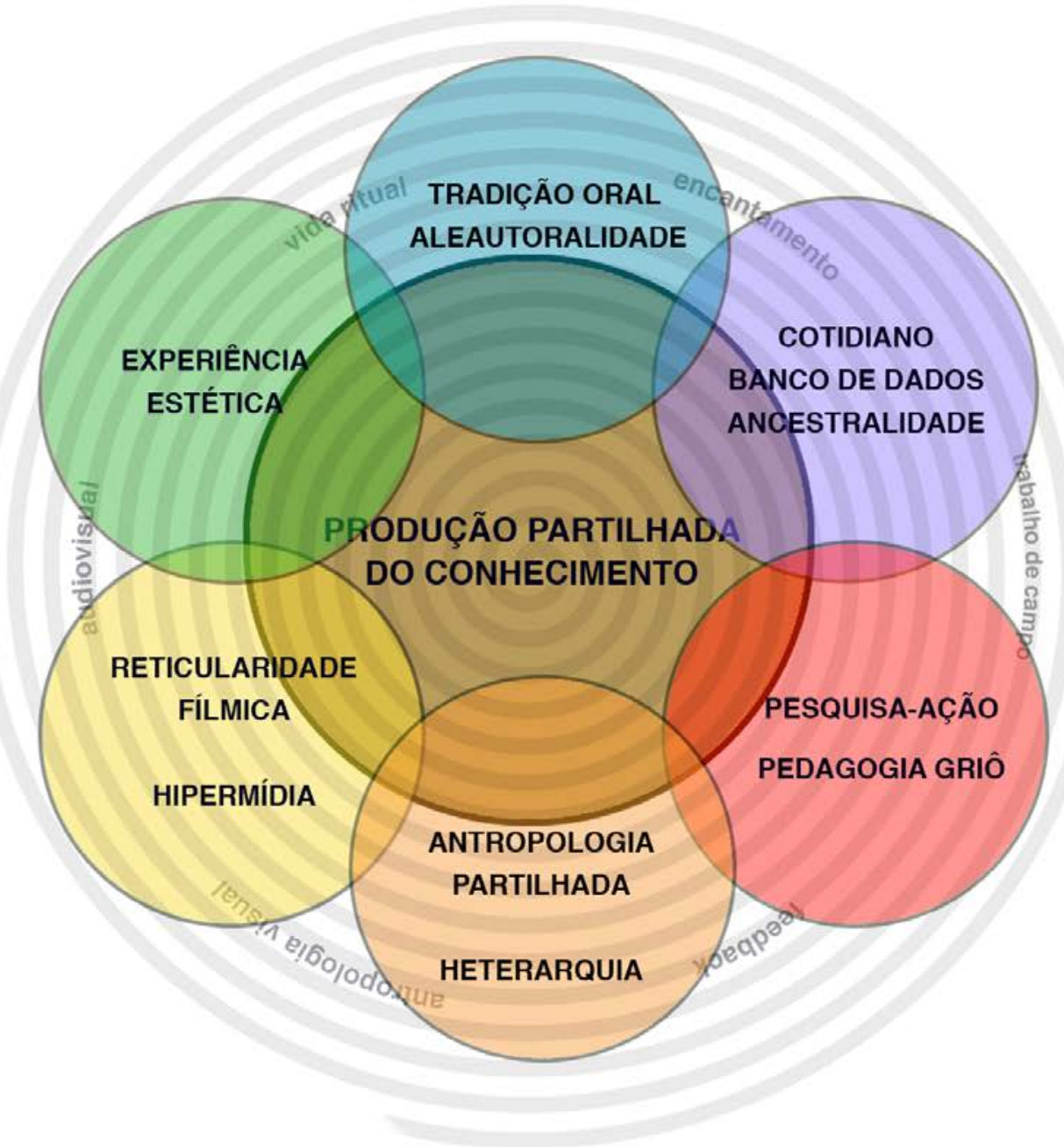

fig.20 - Espiral da Produção Partilhada do Conhecimento. 


\section{CAPÍTULO IV}

\section{DIÁRIO DE PARTILHAS}

\section{Viagem a Hawalo}

O trabalho de campo que envolve a ida à aldeia Iny Hawalo Mahadú (Santa Isabel do Morro) começou a ser pensado em Outubro de 2014. Na ocasião, Juanahú Iny ligou-me algumas vezes no transcurso de um mês, convidando-me a pensar, junto dele, a realização de filmes sobre os araunãs da cultura Iny.

O convite pressupõe uma etapa fundamental à metdodologia da Produção Partilhada e, portanto, prontamente passamos a elaborar um projeto para dar conta da empreitada. Esta oportunidade mostrou-se ainda mais interessante pois finalmente seria possível levar à comunidade Iny cópias (em dvd) do filme de Juanahú, devidamente finalizado. Para tanto, 500 cópias foram conseguidas junto ao Cedipp, nosso centro de pesquisa.

Desde os primeiros diálogos sobre a possibilidade de realizarmos estes novos filmes, manifestei a Juanahú a ideia de que aproveitássemos as temáticas para pensarmos na construção não mais a partir de - tão somente - uma montagem linear, mas que tentássemos explorar a possbilidade de construir caminhos reticulares, isto é, o que temos denominado "reticularidade fílmica".

Juanahú mostrou-se bastante entusiasta da ideia. Levanto aqui a hipótese, outras vezes elaborada, de que o audiovisual em um percurso reticular/ hipermidiático, dialoga com a capacidade de condensar estéticas e escolhas em uma relação mais densa e aprofundada com os modos de vida de comunidades de tradição oral. Basta passar um dia junto a um interlocutor como Juanahú, em sua comunidade, para perceber como os caminhos que sua oralidade percorre, proporcionam uma enorme gama de escolhas que dificilmente (ou insuficientemente) podem ser traduzidas em um único curso. Isto é algo que fora 
apartado da vida do homem urbano, imerso em uma dinâmica produtivista, objetiva, da vida na cidade.

Neste novo percurso, com o consentimento de Juanahú, convidei os amigos Caio Luiz e Yudji Oliveira para nos ajudarem na produção dos filmes. Ambos têm experiência em produção audiovisual e já haviam manifestado algum interesse etnográfico.

Em diálogo com Juanahú, chegamos enfim a sugestão de trabalharmos ao longo do mês de janeiro de 2015.

\section{São Félix do Araguaia}

Chegamos à São Félix do Araguaia após exaustivas 24 horas de ônibus partindo de Goiânia. Uma viagem desta dimensão sempre me faz refletir sobre o quão distante, de fato, estão as grandes universidades brasileiras das comunidades de tradição oral deste país continental (não só do ponto de vista conceitual quanto geográfico mesmo).

Juanahú buscou-nos na rodoviária por volta do meio-dia. Reencontrá-lo em São Félix, após aproximadamente três anos do início dos processos de Produção Partilhada, entre os iny, foi uma experiência muito grata. Almoçamos juntos e, durante a conversa Juanahú ,relatou novos casos de suicídios, ao menos dois, ocorridos em duas aldeias diferentes, somente nos primeiros dias do ano.

Um dos casos acontecera com um primo bastante próximo seu. Segundo ele, praticamente um irmão. A triste notícia ensejou uma reflexão sobre se seria, de algum modo, importante e conveniente a realização de um filme sobre a temática. Algo que buscasse encontrar reflexões no seio da comunidade, junto a interlocução de um Iny. Juanahú demonstrou interesse em fazê-lo, assim como nós nos mostramos dispostos a ajudá-lo a pensar formas possíveis. No entanto, acredito que somente descobriremos se a vontade persistirá no transcorrer do trabalho de campo, haja vista que trata-se de uma questão bastante pungente e que demanda uma enorme cautela. Na chegada à aldeia, pela tarde, Juanahú 
finalmente abriu uma das caixas com os dvds. Seu rosto não escondia a felicidade e o orgulho que inundavam aquele momento. Seus três filhos, Iexika, Heranaki e Malauiru, andavam de um lado ao outro, pegando alguns dvds na caixa e, alegres, conversando algo em Iny que, me parece, remetia também à alegria do pai. Em mim, a satisfação também era imensa. Finalmente a última etapa de um longo processo de Produção Partilhada estava concluído, faltando somente a exibição do filme na aldeia Fontoura (Btoiry), onde fora o mesmo filmado. Sugeri à Jua que projetássemos o filme nas águas do rio Araguaia, já que o mesmo trata do "povo que veio do fundo do rio". A ideia parece ter sido bem aceita.

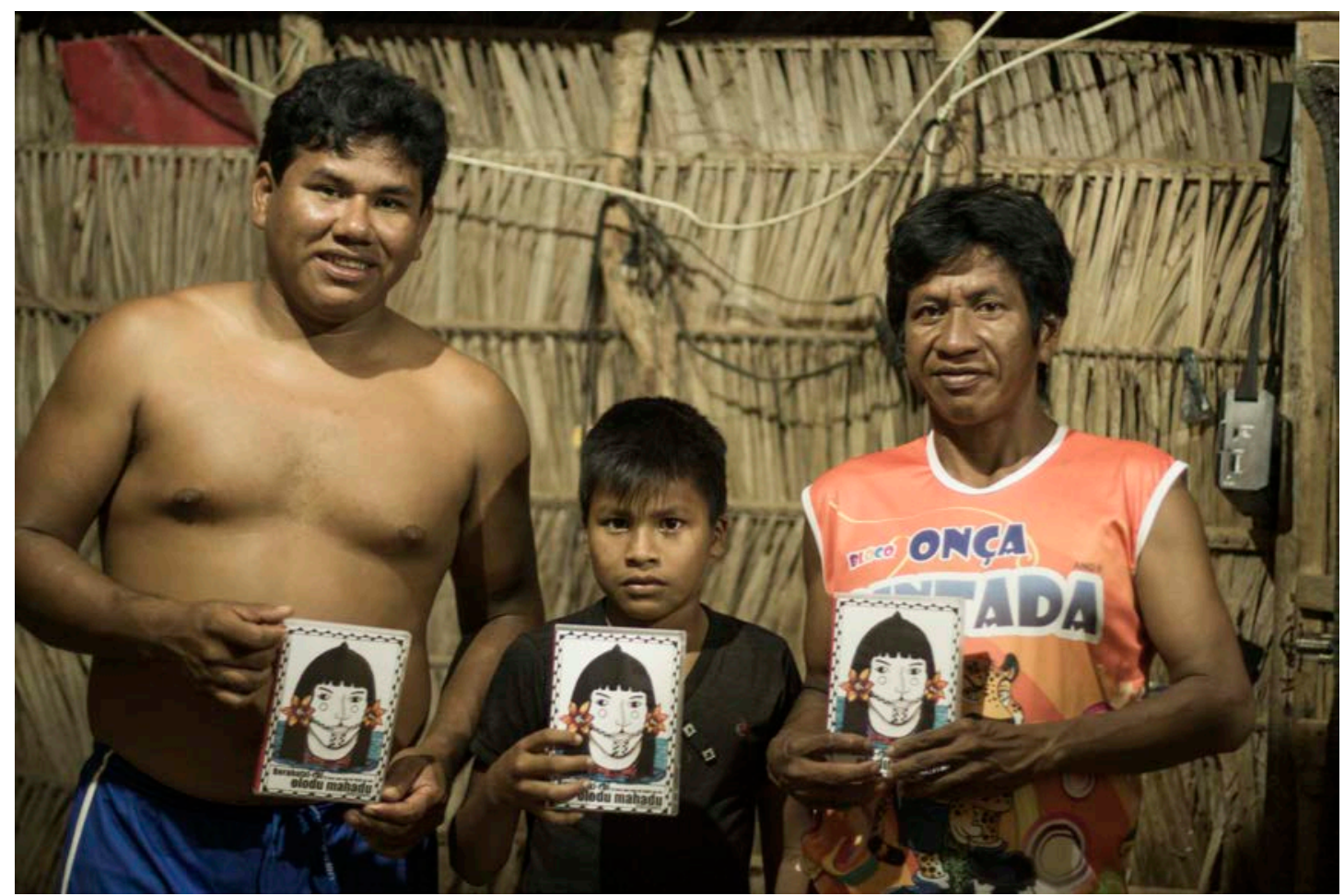

fig. 23 - Juanahú distribui o dvd "Berahatxi-rbi Olodu Mahadu" para o menino Hariteburé e para seu amigo Uriwau na aldeia Hawalo. (Foto: Caio Lazaneo)

Pela noite, por fim, projetamos na parede externa do Hetô (casa) (que Juanahú disponibilizou para nossa estadia) o filme "As Hiper-mulheres" (2011) do amigo Takumã Kuikuro, de Carlos Fausto e Leonardo Sette. Para mim, que já conhecia o excelente filme, sabia que ele poderia inspirar cinematograficamente Juanahú, no sentido de explorar novas formas e pontos de vista diferentes dentro de um ritual. Pela rápida conversa que tivemos após assisti-lo, fiquei com a 
impressão de que o filme lhe tinha sido inspirador, já que comentou algumas vezes, por exemplo, que há na cultura Iny uma infinidade de histórias e que ele desejaria muito contá-las. Nas entrelinhas, fora bonito observar durante o filme, uma relação de bastante afeto entre pai e filhos. A todo momento Juanahú se reportava à Iexika, Heranaki e Malauiru comentando questões do filme. Em alguns momentos externava a nós que seu desejo era de que os filhos se tornassem, no futuro, fotógrafos e editores de seus filmes.

Logo cedo registramos um diálogo com Juanahú a propósito de quais seriam suas ideias para a realização do filme. Durante o diálogo, uma de suas ponderações fora ao encontro da dificuldade de se realizar um filme Iny em uma única linearidade. Juanahú comentava sobre a complexidade dos momentos em que em um ritual (como o Hetohoky por exemplo) acontecem diversas ações correlatas. Assim, por mais que fosse possível deslocar equipes para realizar registros simultâneos e os mesmos fossem organizados linearmente na estrutura de um documentário - ainda que fazendo uso de recursos como a montagem alternada -, esta forma de composição apontaria um caminho bastante restritivo.

Juanahú também relatou fatos recente que ocorreram na aldeia como a queima proposital da "casa dos aruanãs", onde encontravam-se quatro máscaras. Segundo ele, possivelmente isso teria sido obra de algum "bêbado". Talvez um pouco constrangido por este fato e, ao mesmo tempo, aparentemente sem ter tido uma elaboração mais profunda de suas ideias fílmicas, Juanahú passou a contar-nos muito mais sobre as suas preocupações quanto ao que pode representar a ausência dos aruanãs à cultura Iny do que seu projeto inicial para contar a história dos mesmos. A nós, pareceu que a ideia de realizar um filme justamente sobre o onipresente conflito geracional, impresso também no binômio tecnologia x tradição, que por sua vez implica em um certo desinteresse do jovem Iny pelas festas de Aruanã, pudesse talvez ser algo também tão interessante quanto. Esta, aliás, parece-me ser uma temática habitual entre autores de filmes indígenas (o colega xavante Divino Tserewahú, por exemplo, abordara esta temática de um modo muito singular em seu filme "Tsörehipãri"), já que uma enorme parcela de suas aldeias vivenciam o dilema cotidiano de 
conviver cada vez mais com equipamentos eletrônicas e facilidades da "vida moderna" ao passo que seus jovens demonstram um crescente desinteresse em práticas tradicionais (danças, festas, artesanatos, pinturas corporais, etc).

A mim, cada vez mais fica evidente que um filme elaborado de modo plenamente dialógico, inevitavelmente redescobre-se a cada dia, a cada nova conversa, sendo impossível estabelecer uma meta, um objetivo específico. Como parte de uma pesquisa-ação, cabe ao pesquisador compreender e respeitar as demandas da comunidade na interação com suas problemáticas.

O fato é que deste longo diálogo - algo em torno de uma hora e meia - não tivemos, juntos, uma ideia muito elaborada sobre o cronograma de "produção" do filme e, tampouco, qual será sua abrangência. Isto é algo que em situações anteriores me tiraria o sono mas que, depois de algumas experiências singulares durante os processos de Produção Partilhada, pude compreender que não haveria como ser de outra forma. A aleatoriedade de um ser-tão oral implica na escolha da aleatoriedade como expressividade estética. Nas palavras de Juanahú: "A aldeia é circular"154.

Pela tarde acompanhamos algumas partidas de um campeonato de futebol local, um situação lúdica que movimenta toda a aldeia. Todas as equipes femininas e masculinas - têm seus uniformes, alguns dos quais (como o time “Tocantins", cujo padrinho é Juanahú) trazem grafismos Iny estampados nas camisetas. A grande maioria dos jogadores utiliza-se de chuteiras e outros aparatos para a prática do esporte. 0 futebol por sua vez apresenta uma circularidade inerente. A meu ver é o único fenômeno que compete em pé de igualdade - no sentido de mobilizar tantas pessoas - com os rituais que presenciei entre os karajá e xavante.

De fato, é absolutamente interessante uma espécie de ritualização do futebol que transcorre com tamanha naturalidade nestes contextos e não deixa

\footnotetext{
${ }^{154}$ Esta afirmação é curiosa sobretudo por dois aspectos: 0 primeiro é que Juanahú dera esta resposta ao falar sobre a dificuldade de organização sistemática e linear/retilínea de um filme que tratasse da cultura Iny. A segunda é que, paradoxalmente, as aldeias karajá não se organizam em formato circular, como no caso das aldeias xavante (em formato de ferradura), mas sim de forma (talvez) mais dispersa e "quadrangular", o que, por sua vez, embora configure-se enquanto um aspecto geográfico e arquitetônico importante, não o impede de compreender filosoficamente uma aldeia karajá como um habitar em circularidade.
} 
de ser interessante notar que, por outro lado, provavelmente o tempo que os jovens dedicam à prática esportiva, naturalmente lhes subtrai alguma parte do tempo que dedicariam a aprender cantos, danças, entre outras tradições.

Pela noite Juanahú inesperadamente nos chamara em nosso heto, às pressas, para que fossemos com ele registrar a chegada de um barco de uma outra aldeia que vinha à Santa Isabel trazendo homens para lutar a luta ijesu. Em meio a uma profusão de danças, lutas e cantos, marcou-me o comentário breve de Juanahú - enquanto passava de braços dados a um companheiro em uma dança: "Ta vendo por quê é tão difícil esse negócio de linearidade?"

Pela manhã, acordamos no hetô para ir ao encontro do cacique Idiarrina e, pretensamente, gravar uma entrevista. Juanahú nos esperava para o café que, assim como todas outras refeições, temos partilhado com sua família. A presença da comida tori (não indígena) cada vez mais forte na cultura Iny (e com grande incidência na casa de Juanahú) faz com que as diferenças no aspecto gastronômico, a mim, quase não sejam notadas.

De acordo com Juanahú, sua esposa "gosta de cozinhar como toris" e é notável que ela cozinha realmente bem. Em suma, a alimentação tem sido a base de muito arroz, feijão, galinha e farinha. Paradoxalmente, a despeito do gigantesco rio a uma pequena distância de onde ficamos, temos comido pouco peixe. Após o café, finalmente encontramos com o cacique Idiarrina em sua casa, um encontro pelo qual havia uma considerável expectativa, uma vez que a autorização para que, de fato, pudéssemos realizar o trabalho viria dele.

0 cacique Idiarrina é um senhor de 54 anos com uma admirável retórica. Ficamos por volta de 2 horas ouvindo suas histórias, preocupações, divagações e ideias, praticamente calados. Em alguns momentos Juanahú conversava em Iny expondo também suas questões, ao passo que nos restava apenas um exercício interpretativo. Embora entusiasta e demonstrando aceitação das ideias expostas por Juanahú, Idiarrina nos relatou situações onde a realização de um filme somente fora permitida mediante pagamento em dinheiro ou permuta, por exemplo, por equipamentos.

Dentre outras situações tais como uma oportunidade em que "japoneses ou chineses" (ele não se lembrava com exatidão), deram um veículo em troca da 
autorização de filmagem, o cacique deu ênfase ao caso de um francês que por lá passara e que não havia cumprido o que fora acordado entre eles (segundo relatara, o francês teria prometido dar uma câmera de presente, o que não ocorrera).

Sua fala procurava reforçar uma preocupação (bastante comum) de que os Inys sempre são frequentemente registrados e nada ganham com isso. Para mim fora curioso ouvir ele dizer, por exemplo, que diversos pesquisadores amiúde por lá passam e que, a estes, o que interessa, por fim, é apenas "receber um certificado". Em algumas oportunidades sentia bastante vontade de problematizar mais as questões que ele colocava sem, no entanto, me sentir à vontade.

Quando o fiz, aguardando um intervalo em sua longa exposição, reforcei o que estávamos querendo comunicar com a Produção Partilhada era - sobretudo no que diz respeito à autoria dos filmes e a perspectiva conjunta de produção de conhecimento, entre universidade e comunidade - uma proposição na qual, Juanahú, entre os Iny, seria o interlocutor e, portanto, o autor. Busquei sublinhar a diferença que havia, por exemplo, entre o trabalho de uma TV estrangeira que vai até uma aldeia e paga uma quantia considerável para registrar seus rituais (e depois vai embora sem deixar algum retorno - que não seja propriamente material), de uma premissa formativa, onde o protagonismo da autoria é partilhado, como o que estávamos propondo.

Idiarrina parecia concordar ao passo que, por vezes, dizia que de algum modo o interesse dele seria um e o de Juanahú outro (o que me deixava bastante desconfortável, já que compreendo na fala e nas práticas de Juanahú uma preocupação absolutamente comunitária). 0 que para mim, trocando em miúdos, parecia apontar um caminho em que se o filme não pudesse efetivamente ser "monetizado" (a priori) e isso de algum modo não retornasse à comunidade do ponto de vista material, seu cacique não nutriria assim tanto interesse.

Das tantas vezes em que, antes de realizar um trabalho audiovisual com comunidades, dialoguei com uma liderança para que pudesse autorizá-lo (e consequentemente legitimá-lo), esta até hoje me pareceu a situação mais delicada. Comigo persistia o pensamento de que se tivéssemos de chegar a uma situação limítrofe, onde a realização somente fosse permitida se alguma quantia 
estipulada tivesse de ser paga, não me interessaria mais continuar na empreitada.

O fato é que o pressuposto básico para o desenvolvimento deste trabalho se dera a partir dos recorrentes convites de Juanahú para que pudéssemos, juntos, pensar filmes possíveis em sua aldeia. 0 interesse da pesquisa (de ambos), em si, já consistiria enquanto uma troca, portanto pagar por esta relação para mim sugeriria uma espécie de misé-en-scene antropológica, bastante perigosa e que infelizmente é sistematicamente alimentada pelos trabalhos que, em tempos atuais, substituíram os espelhinhos dos colonizadores, por veículos e equipamentos.

Quanto a esta situação não me caberia criticar a liderança com quem conversava, uma vez que penso que eram, sob alguns aspectos, bastante coerentes suas reivindicações. É natural imaginar que as comunidades indígenas, de modo geral tão solapadas de suas terras e tão à mercê dos problemas introduzidos pelas sociedades não indígenas (e não só), recorram com frequência a um protecionismo inerente que somente passa a olhar com algum interesse para a interculturalidade quando essa lhe pode apresentar algum ganho efetivo. De algum modo, isto aponta para um feedback negativo que busca reequilibrar uma relação desigual.

Por fim, assim que as ideias se assentaram e embora a entrevista que planejávamos gravar na manhã não pudesse ser realizada por conta do longo diálogo, Idiarrina curiosamente nos convidou para registrar, para o filme, duas situações que estavam acontecendo em sua casa. A primeira sobre o processo de escarificação em formato circular abaixo dos olhos (uma marca tradicional da cultura Iny) que estava sendo realizado em sua filha, e a segunda sobre uma pequena celebração que em sua casa aconteceria por conta da primeira menstruação de outra de suas filhas. Combinamos de realizar o registro da primeira na manhã seguinte e a segunda quando a celebração acontecesse, quatro dias depois.

Após a conversa com o cacique nos dirigimos ao campo de futebol da aldeia, onde acontecia os campeonato local, a fim de registrar um pouco deste contexto. A nós, este parece um importante eixo em qualquer filme que trate da 
cultura Iny nos dias de hoje, um fenômeno que efetivamente tem uma enorme força em seu cotidiano.

O mais curioso desta situação fora o fato de que não vimos jogo algum já que uma discussão acalorada acontecia entre os integrantes de algumas das equipes que discutiam sobre o regulamento do campeonato e algum ponto de discórdia, em torno dos critérios de classificação, para a continuidade do mesmo.

A mim, remeteu a outras situações que presenciei, em campo, de discussões acaloradas sobre a continuidade (ou o funcionamento) de um determinado ritual, de uma determinada festa. De fato, o futebol novamente mostrava sua vocação ritualística. Pela tarde, não por acaso, jogamos uma animada (e despretensiosa) partida de futebol ao lado do hetô de Juanahú. De um lado ele e suas filhas Herenaki e Malauiru, do outro eu, Yudji e Iexika.

Após o futebol Juanahú trouxe um papel onde constavam anotados os nomes Iny que sua esposa havia escolhido para os três toris que a família acolhia: Asaria seria meu nome, Kumary de Yudji e Ijahure de Caio. Segundo ele, eram nomes da linhagem de sua esposa, neta do famoso Iny, Wataú, com o que ficamos muito honrados.

Como era de se imaginar, após o futebol, a intimidade com os filhos de Juanahú (que no princípio era apenas desconfiança por parte das crianças) cresceu exponencialmente e, até boa parte da noite, os três não paravam de criar brincadeiras tentando inserir os toris nas mesmas. Golaço, ludicamente já me sinto em casa!

Os dias e noites em Hawalo têm sido um tanto polarizados. Ao longo do dia passamos um calor exasperador, que em alguns momentos chega a prejudicar a dinâmica das gravações, já que os equipamentos (sobretudo as câmeras) costumam esquentar de forma muito mais rápida. Nos raros momentos de descanso quando, após almoçarmos, tentamos descansar brevemente nas redes, o calor, sem dar trégua, traz desconforto à sesta. Por outro lado, nas noites a temperatura tem sido mais amena, chegando até mesmo a exigir utilizar o saco de dormir para aliviar o vento gelado que sopra do rio Araguaia. Há quatro dias temos, diariamente, espantado um rechonchudo sapo cururu que insistentemente se posiciona em meio às nossas redes. Depois de tanta 
insistência em afasta-lo e, mesmo quando esse "chega pra lá" se dá de modo abrupto (como nas vezes em que Herenaki, filha mais velha de Juanahú, decide a nosso contragosto, arremessá-lo ao longe), o danado insiste em voltar. Acabamos por fim aceitando a presença do anfíbio.

Nos últimos dias, Juanahú nos contara algumas vezes e com enorme entusiasmo o mito do Yré, demonstrando vontade de realizar um filme ficcional sobre o mesmo. Yré é um jovem Iny que, após ser rejeitado pelos pais desde seu nascimento, recebe os conselhos de um sapo (que dê algum modo retransmitia os conselhos de sua vó - aquela que por fim o criara) sobre como matar um macaco que impedia que ele prosseguisse em sua caminhada. Curiosamente Juanahú tem um medo descomunal de sapos, no entanto, assim mesmo, aceitamos a presença do cururu em nosso hetô. Oxalá ele possa nos trazer bons conselhos.

\section{MITO DO IYRÉ155}

Caio Lazaneo: Ô Jua, pode contar como você quiser cara... que você já...

Juanahú Iny: Wato itsiwadze, atsima apirana ${ }^{157} \ldots$

Caio Lazaneo: Que eu sei que você gosta muito...

Juanahú: Yré? Eu vou contar resumido, tá?

Caio Lazaneo: Tem tempo Juá, como você quiser.

Juanahú. Tá. Yré, não era nem nascido. A mãe tava grávida de Yré e não sabia que era Yré. E quando nasceu era meio doente né? Yré nasceu doente. Só que naquele

155 Pronuncia-se ãré. Relato oral por Juanahú Iny.

$156 \mathrm{O}$ áudio do mito pode ser ouvido no texto em .pdf digital (em leitores de pdf como o Adobe Reader).

157 Wato itsiwadze e atsima apirana são expressões xavante correspondentes a:

“ - Não estou nem aí, te vira!”. Esta expressão popularizou-se de forma lúdica entre mim, Juanahú, Divino Tserewahú e Paulinho Kadojeba, durante os trabalhos de Produção Partilhada, como uma espécie de brincadeira que, entre os xavante, provoca muito riso, diga-se de passagem. 
momento o casal não gostaram do próprio filho e depois não colocaram nome né, chama Yré. Yré quando cresceu, doente né, quem criou foi a vó. A avó criou, quer dizer, a vó que adotou... Na verdade na história o pai não era tanto assim, quem não gostava era a mãe né. A mãe do Yré tinha tudo, pois o pai dele pescava e a mãe dele fazia esteira. E quando o Yré se tornou um rapaz assim, que cresceu, então a avó adotou e dormia assim numa esteira bem desgastada mesmo, sabe, porque antigamente usava mais esteira. Dormia com avó e a mãe nem lembrava dele, porque, Yré, era tipo uma catapora né, eu fico imaginando, uma doença de catapora, parece era tudo ferido...

\section{Caio Lazaneo: - Yré nasceu assim?}

Juanahú: Yré nasceu assim. Só que com tempo certo a mãe que criou né. E de lá ela não queria mais, porque a criança nasceu doente e tal então a avó criou. Então a avó catava um alimento, um restante de comida, né, vamos dizer assim aquele espinho de peixe, porque antigamente comia... catava e colocava, chamava watxiwi, e ajuntava e colocava no pilão para poder fazer iweru, tipo canjica né, como um caldo. Então naquele tempo Yré veio crescendo. O Yré era muito bom, dizem que ele respeitava a avó. E a mãe não gostava e nem o pai. Então Yré começou crescer, com a idade de 10 a 12 anos teve que sair com a vó em busca de weriri, saía e começava a atirar nos passarinhos. E foi indo, atirando nos passarinhos, buscava a flechinha dele e voltava. Aí uns dois anos depois, o Yré ainda estava com a mesma doença dele né, espalhado na cabeça tudo. Ai ele voltou e tinha um pássaro lá, eu não me lembro o nome do pássaro. Yré começou a mirar no pássaro, só que ele voava. Ele voava para atirar no lugar certo para poder a flecha cair na boca do buraco da cobra coral. Então ele começou a atirar, quando caiu ele falou:

- Vó, eu vou buscar minha flecha.

A avó já estava acostumada com ele buscar as flechas. Então ele foi lá e a cobra coral pegou ele. De lá a avó dele voltou chorando, sabe? E começou a chorar... tem um choro né, para neto quando se machuca, quando morre, têm vários choros. Ela começou a chorar, tipo assim que o Yré morreu. Hoje eu posso dizer assim, 20 anos depois Yré voltou. Só que a história começou na avó, depois da avó vai para, como é que fala? Para a cobra coral. A cobra coral cuidou dele. A cobra coral diz que tinha duas filhas bonitas né, e começaram a cuidar dele. Só que o cara lá né, o cobra, dizia:

- Cuida do seu irmão.

Só que ele já disse: -Se fizer alguma coisa com você, você me avisa.

Que as duas meninas não podem ter relacionamento com Yré. Porque o pai dele era muito assim, hyrí né, sabia de tudo. Então começaram a curar ele. Com cada raíz, diz que a primeira raíz não deu efeito, né, pra ele curar. Então na segunda acho que acertaram, mudaram de remédio dele e começaram a banhar ele, sabe? E deu certo, começou a falhar aquela doença dele. E Yré começou a crescer também. Então de lá diz que o Yré falou assim: Agora eu vou te levar, vamos fazer teste, ver se você está bom mesmo. Se chamava deoreru. deoreru para nós se fala rede, rede de pescar né. Ele foi com o que chamava wary né, wary parece. Diz que era o tio deles que pescava pirarucu. Só que antigamente a rede não era 
em cima daquela água, né. A rede de tori. Antigamente a rede que eles colocavam era embaixo né, embaixo do lago. Eles faziam com aquela que chamava adu. Uma corda que dura dentro da água né, a hora que o peixe entra, ele pode tá pegando igual rede, ele não sai, ele nem abre. Então ele diz assim ó: - Vamo lá, agora é sua vez de brincar. Ele fez teste na frente:

- Ó assim que faz!

- Eles ficaram no espírito do peixe pirarucu.

Brincavam e ele disse: - Você tem que fazer isso. Esse pessoal que armaram aqui são gente. São seus tios. Seu avô, são da sua família.

E ele: - Ah eu não vou não, senão eu vou morrer.

- Não Yré, vai! Yré não queria ir. Então Yré foi depois. Ele foi e ai ele foi maiado na rede. Ele falou assim:

- Faz o que eu te falei, faz isso.

Então ele chamava assim:

- Eu vou morrer, eu vou morrer.

Ai ele falava que não, o Yré não ia morrer não: - Eu quero que você tenta.

O espírito dele é muito forte. Entrava no espírito da piranha, cortava aquela malha da corda e soltava ai saía cansado na beira do lago. Ai ele voltou de novo e não tava bom. Ai começaram a dar mais remédio caseiro. Yré, essas duas meninas pintaram ele. Pintaram ele porque ele tava curando né. Aquela robi né, pintura de weriribó. Eu não sei como era a pintura de weriribó né. Isso do Yré é antigo. Por isso que eu quero fazer filme. Quero buscar mais histórias. Então de lá, as duas meninas mexeram com Yré, tocou nele, né. Só que, acho que chegou a fazer relacionamento com as duas meninas. E diz assim ó:

- Eu vou te dar um sinal para você. Que tu vai me acertar quem mexer contigo.

O sinal não sei qual lado que deu. Então de lá o pai descobriu e por isso que o Yré tava fraco, né. Não conseguia sair. Porque assim, quando tem relacionamento, diz que tira mais ou menos $80,90 \%$ de energia né. Então isso que ele fez e falou pra ele:

- Qual que mexeu contigo?

Só que yré não queria falar. Porque ele não queria que a irmã, vamos dizer assim a irmã né, que o dele fizesse mal pra ninguém. Ai disse que ele viu assim, a mulher fez assim com o rosto e viu tipo um sinal pretinho aqui, e ai falou:

- Foi ela!

Ai falou: - Por que que ele fez isso?

Ai a mulher falou: Ela achou bonita.

Yré não vai poder morar aqui com a gente. 0 Yré a gente trouxe aqui para gente ver a situação dele, porque ele tava sofrendo. Agora não, agora virou homem. De 
lá Yré veio para a avó, 20 anos depois. Eu imagino assim né, 20 anos depois. Com uns 22. Cobra coral deu flecha para ele de reserva, arco de reserva e para beber água que chamava, roo, hoje é muito difícil ver, antigamente eu, quando nasci, já vi o meu avô levando água dentro. Roo, é bonito cara..

Ai falou para ele assim ó:

- Você tá pronto Yré! Você tá pronto porque agora eu vou te levar.

Levaram yré, levaram yré e falou assim:

- Não olha para trás.

Parece. Ai ele veio, chegou.

Mais ou menos assim chegando na aldeia, falou assim:

- Ó Yré voltou, Yré voltou!

Antes de ele vim, a história vem para a avó agora. 0 amigo dele batia na porta da avó assim:

- Vó eu sou o yré!

Ai a avó dele abria e cadê o Yré? E as crianças saíam rindo dessa senhora. Ai o amiguinho.. depois a mulher não queria abrir a porta da casinha dela né, porque tavam brincando com ela.

Então o Yré de verdade chegou e era bonito, igual eu. Ai chegou numa aldeia lá e falou:

- 0 Yré voltou.

Ai falou para a vó:

- Vó, voltei!

Ai a vó sabia a voz dele né. Ai abriu a porta que era ele. Bonito, pintado. Ai diz que quando a mãe dele que soube que tava chegando, que chegou, ai trouxe a esteira bonita e jogou assim ó:

- Meu filho querido, senta aqui, sua cadeira é essa aqui.

- Não é essa aí que é a minha esteira. Vó, cadê minha esteira?

Ai a vó dele foi com a esteirinha né, que dormia naquela esteirinha né. Soltou lá e sentou. Ai diz que a mãe dele tava lá pegando um peixe né...

- Aqui meu filho, sua comida...

-Não, não é essa daí que é a minha comida. Vó cadê minha comida?

Então a avó foi buscar a mesma comida que ela fazia né, com o restante das comidas sabe. Catava do lixo. Então fazia a mesma comidinha. A história fala que não sei quantos dias, com certeza viveram muito tempo juntos e depois resolveu sair da casa da avó, falando duma palavra assim:

- Vó agora eu vou. Eu vou atrás do.... 
Não me lembro cara, tem hora que voa a história...

- Agora eu vou atrás daquele que... Eu vou, assim né, seguir o caminho né.

Onde que meu tio, meus vôs, que foram, então eu acho que tenho que ir nesse lugar. Então o Yré, eu me esqueci lá. Antes do... cobra coral, falou assim:

- Você tem que agradar sua vó... Negócio de sapo lá, sabe. 0 sapo falava assim:

- Você tem que agradar. 0 sapo lá falava assim: - Ô fica comigo, tal...

Ai ninguém agradava a vó por isso que quando ele passava lá que falavam assim:

- Ó, você vai morrer. 0 macaco lá vai te acertar bem no coração.

Então o cobra coral ensinou o Yré falar isso:

- Na hora que sua vó falar pra você, você tem que agradar.

Então Yré veio tudo preparado na guerra. Yré chegou e falou assim:

- Vó eu to saindo.

E ai foi, ai seguiu onde que os tios iam buscar, assim, hoje eu considero hoje onde que eu tô. 0 Yré abiu o caminho. Só que eu não sei, eu nunca finalizei a história Ai, Yré chega... Saiu de manhã, e diz que ele anoitece lá onde o sapo gosta de ficar. Então sai de manhã e quando foi a tarde chegou num lugar onde que tá o sapo. Ai viu assim ó:

- Nossa, você é bonito meu filho. Eu só preciso de uma coisa de você. Eu quero que você fica comigo.

Então o Yré, já vê tudo né... Ele não ia chegar e pegar assim.. ele só pegou a flechinha né, foi na perninha dela lá e de lá ele fez:

- Annnnnn. Muito obrigado meu querido filho, neto, você vai acertar. Você vai matar aquele macaco, né, que matou seus tios, que matou sua família.

E no outro dia, chegou lá. Só que única coisa falou assim, você fala pra ele e ele vai te exigir você jogar primeiro o arco nele. Só que você fala, que nunca aceita, tem que ser ele.

Então, tipo assim, já cai no feitiço né. Que foi lá e falou:

- Não, você que vai jogar.

Então os dois se trocavam..

- Não, você que vai.

O macaco convenceu o macaco joga a flecha nele e atirou e errou. Ai diz que ele falou assim: 
- Agora você vai mirar né, não pode acompanhar.

Ai ele atirou certinho no meio e acertou.

Só que eu vou te falar a verdade. Em português é muito difícil contar para mim né. Na minha língua é assim né, eu conto mais ainda. Por isso que pra fazer um roteiro eu conto na língua e ao mesmo tempo eu tenho que gravar as mais velhas né. Porque Yré não finaliza, ele é uma história muito curtinha, não chega a duas horas não. Mas dá para fazer um filme de 15, como é que fala? Filme curtametragem.

Caio Lazaneo: - Mas aí acaba aí? 0 Yré flecha o macaco?

Juanahú: O Yré abriu caminho, para todos iny. Então a chegada do Yré seria mais ou menos numa aldeia assim. Abriu o caminho de Fontoura, esse BR que vai aí, entendeu? Que ninguém ultrapassava esse lugar. Quer dizer, para mim o pessoal de Fontoura queria vir para cá mas o macaco não deixava, matava lá mesmo. Então o Yré resolveu o caminho. Então hoje o caminho foi para o Javaé, foi para Fontoura, Macaúba. Então no filme eu imagino assim, pegar uma gurizada e o Yré chegando de lá com flecha, pintado... Eu vou ser Yré. Ele não chega onde que chega, não finaliza. Mas a gente pode contar história né. Procurar mais senhoras, um senhor que sabe, só que eu já entrevistei vários iny e não chega o final. Chega e diz que ele começou a abrir...

Caio Luiz: - Esse é o final!

Caio Lazaneo: - É o final.

Juanahú: - Esse é..... esse é o final

Pela manhã logo cedo nos dirigimos à casa do cacique Idiarrina para possivelmente registrarmos a escarificação iny de sua filha. Por alguma confusão em relação ao horário acabamos não o encontrando e sua esposa sugeriu que voltássemos no dia seguinte. A agenda das lideranças iny costuma ser bastante cheia, por vezes percorrendo diariamente muitos quilômetros na Ilha do Bananal tratando de interesses econômicos, políticos, etc.

Da minha parte confesso que ainda não me adaptei ao horário praticado na aldeia, ao menos os horários ditados por Juanahú. Minha impressão é de que esta parte do Brasil central vive em permanente crise com o fuso-horário (sobretudo por conta do horário de verão). Por vezes o que vale é o horário de Brasília, em outros momentos o horário de Mato-grosso. Juanahú, por sua vez, 
parece misturar ambos e sugerir horários que nunca batem com o meu relógio (que por sua vez marca o horário de Brasília). Assim, minha opção é apenas seguir sua sugestão. 0 horário rígido já nem importa tanto, restando acompanhálo quando decide efetivamente sair do hetô.

$\mathrm{Na}$ impossibilidade de gravarmos na casa de Idiarrina, conversamos rapidamente sobre o que filmar. Como um roteiro aleatório, em um entorno reticular, a montagem durante a observação vertovniana - como força motriz da situação de rodagem de um cotidiano - parece surgir espontaneamente. $\mathrm{Na}$ ausência do cacique, chefe político, fomos ao hyri (pronuncia-se rãrí), chefe espiritual.

0 eixo principal do(s) filme(s) tem, agora, se afirmado como uma busca por uma festa de Aruanã que já não mais acontece. 0 filme se (re)monta no imprevisto do cotidiano. Chegamos assim à casa do hyri Sokrowé, um iny que embora pareça jovem para sua função, com pouco tempo de conversa já é possível atestarmos porquê a ocupa.

Sokró nos narrou como se tornara hyri. Um dia, em uma lagoa da Ilha do Bananal, tomara um choque muito forte que segundo ele era o chamado do Aruanã. Após o choque ficou muito doente por dias, sem comer, sofrendo com alucinações. E assim, à medida que se recompunha, ia descobrindo seu dom. Os hyri Iny obedecem a esse chamado e passam a desenvolver-se como curadores, conselheiros, chefes cerimoniais, etc. O sonho, segundo ele, constituía um momento de aprendizado.

Registramos uma conversa de Sokró com Juanahú em duas locações distintas. Uma próxima à sua casa onde ele relatara sobre como se tornara hyri e o que isso significa dentro da cultura Iny. A segunda conversa fora próximo do que restara da casa de Aruanã, onde recentemente (em novembro de 2014) fora ateado fogo (segundo a hipótese de Juanahú o fogo teria sido ateado por algum bêbado).

Sokró falou então sobre o conflito do abandono da tradição, dando sua interpretação sobre a perda do interessa na festa Aruanã. Pela tarde retornamos a casa de Sokró e fizemos um registro de um momento de singular beleza. Sua esposa pintava sua filha e a adornava com brincos, braçadeiras e enfeites da festa de Hetohoky. A troca entre em mãe e filha, o modo com que fazia as pinturas 
corporais e prendia os enfeites nos braços, cabelo e pernas, traduziam uma situação de marcante afeto.

Pela noite, durante o jantar, ouvimos Juanahú relatar diversas de suas histórias, com ênfase, desta vez, na relação conflituosa que tivera com seu pai, durante a infância e adolescência, por conta do alcoolismo paterno. Apesar da pouca idade, Jua é um grande contador de histórias e, não à toa, a possibilidade de contá-las também a partir do audiovisual o faz tão feliz. Pouco a pouco temos sentido uma guinada na temática do filme. 0 que a princípio sugeria um filme sobre os diferentes Ijasó (araunãs), paulatinamente tem se tornado um filme sobre seu iminente abandono.

Os karajá foram, até pouco tempo atrás, inimigos direto dos xavante e até meados do século 20 protagonizaram conflitos com diversas etnias como os kayapó, tapirapé, entre outras. Em sua dissertação a propósito da Cosmologia Iny, Toral (1992) narra de forma bastante completa as disputas que envolviam o povo Iny até o momento em que definitivamente se estabeleceram na Ilha do Bananal ${ }^{158}$

Destarte, o primeiro filme de Jua, que envolveu na equipe um xavante e um bororo fora, para mim, uma das melhores formas que conseguimos elaborar do ponto de vista teórico-metodológico - a Produção Partilhada do Conhecimento. Interlocutores de etnias que outrora provavelmente se enfrentariam, hoje produzem filmes juntos.

Pela manhã Jua nos narrava algumas destas disputas, embora sua precisão cronológica com frequência não pareça ser tão confiável (e a mesma dificuldade com as horas se faça presente nas datas). Disto se pode destacar um certo respeito todas as vezes em que a história guinava para as disputas com os xavante (povo este tido como muito guerreiro por Juanahú e de modo geral pelos Iny).

Segundo nos contara, os xavante, sempre estratégicos, costumavam atacar pela madrugada, em horários não convencionais para peleja. Também

158 Cf. Procedência e contato com outros grupos indígenas, in: TORAL, André Amaral de. Cosmologia e Sociedade Karajá. UFRJ. Dissertação de mestrado, 1992. 
destacava como as disputas com os tapirapé, que por algum tempo habitaram a Ilha do Bananal, foram facilmente vencidas pelos Iny, já que as casas dos tapirapé possuíam apenas uma porta, sendo fácil afugentá-los e não apresentar saída quando os Iny - em guerra - incendiavam, propositalmente, suas casas.

Jua nos contava estas histórias em frente à casa do cacique Idiarrina. Havíamos combinado de registrar uma entrevista pela manhã ou, se possível, a escarificação de sua filha. Após aproximadamente meia hora de conversa, Idiarrina chegou, desceu de seu veículo e se aproximou de nossa roda. Imediatamente passou a falar sobre uma reunião de lideranças que Juanahú deveria participar para resolver um impasse. Segundo nos narrava, um arrendatário (tori - não indígena) de terras ${ }^{159}$ devia 9 mil reais para a comunidade e amparava-se no fato de ser casado com uma indígena (da etnia xerente) para dar seguidos "calotes". Curiosamente Idiarrina nos disse em tom ligeiramente exaltado: “-Será que ele está pensando que é como 200 anos atrás?”. "Hoje nós temos nossas armas e espingardas para reivindicar". Coincidentemente esta fala somada à conversa anterior com Juanahú levava a pensar que, de algum modo, o método seguia semelhante ao de um passado não tão distante, onde outrora os conflitos eram resolvidos com flechas e bordunas, que hoje talvez pudessem ser substituídas por armas de fogo.

Por conta de um novo compromisso de Idiarrina, não fora possível gravarmos o que havíamos pensado na casa do cacique. Pela tarde fomos de barco à aldeia JK, que leva esse nome por conta do hotel - hoje em ruínas - que o presidente Juscelino Kubitchsek mandara construir no local (e que visitava com alguma frequência). Na aldeia mora Ijawaru, filha do cacique Iwuraru, que está tecendo uma esteira cerimonial para o próximo ritual Hetohoky e que Juanahú fez questão de entrevistar. Aproveitamos também para, das margens da aldeia, assistirmos ao belo pôr-do-sol que, neste lugar, brinda os Iny com uma vista estupenda e privilegiada.

$159 \mathrm{O}$ arrendamento de terras para pastagem na Ilha do Bananal consiste em uma das principais rendas para as aldeias Iny. 
Na quarta-feira, no horário combinado, voltamos à casa de Idiarrina. É curioso notar que o cacique está constantemente atarefado e seu horário cronometrado, por vezes, contrasta com o ritmo que observamos na aldeia. Assim, mais uma vez não fora possível registrar o que havíamos previsto, já que o cacique citou um novo compromisso urgente. A caminhada até sua casa, enquanto rotina matinal, tem se configurado como um primeiro exercício diário, em que, logo após o café da manhã, a equipe começa a refletir sobre o que vai filmar durante a jornada.

Embora após várias tentativas não tenhamos efetivamente conseguido gravar uma entrevista com Idiarrina, penso que este percurso reflete a constante imprecisão de um fieldwork, onde as diversas subjetividades guiam muito mais a pesquisa do que propriamente a vontade do pesquisador. Não haveria como ser diferente. Isto reflete também a reticularidade implícita nas culturas em circularidade. A cada hiperlink que se fecha, Juanahú rapidamente consegue descobrir e propor um novo.

Assim, da casa de Idiarrina, fomos ao hetô do velho Kurania, um artesão e compositor Iny extremamente gentil e amigável. Kurania, é o mais próximo que conheci de um griô nestes dias de Hawalo. Artesão, compositor, pescador, aglutinador de diversos saberes, traduz, em si, a complexidade e riqueza das culturas orais. Pelos relatos que ouço e que colhemos, temo que este patrimônio imaterial, dos saberes griôs, é o que mais corre risco de se extinguir em culturas tão singulares como a Iny.

A força avassaladora (e de modo desigual) com que alguns aspectos da cultura tori tem entrado na aldeia, fomentando sobretudo o desinteresse do jovem Iny, parece sugerir, neste contexto, um conflito entre aspectos da cultura iny e algumas tecnologias específicas - que se acentuaram com a chegada da luz elétrica (inserção da televisão, celulares, motocicletas, etc). Embora, com enorme receio, ainda não me sinta confortável para levantar esta hipótese.

0 fato é que isso aponta para um momento chave: Enquanto os campos de futebol e as veredas repletas de motocicletas estão em plena efervescência, a casa de Aruanã fora novamente queimada ameaçando a realização de um novo ritual, o que incomoda muito alguns inys, sobretudo os mais velhos. 
Dentre os vários depoimentos sobre as possíveis causas para os diversos suicídios de jovens (em torno de 25 jovens, das aldeias Iny localizadas na Ilha do Bananal, suicidaram-se desde 2010), escutamos inclusive relatos sobre ameaças, que partiam de jovens, que teriam dito que se matariam caso a família não lhes presenteasse, por exemplo, com uma motocicleta. Todo este panorama faz parte de um ainda maior, partilhado por diversas etnias, contextos diaspóricos, comunidades urbanas e rurais, em que o jovem amiúde apresenta um elo bastante frágil do processo social.

É bastante compreensível, neste sentido, que Juanahú esteja tão preocupado com o contexto atual de sua aldeia. Por sua vez - o que não deixa de ser curioso - Jua é um assíduo praticante do futebol (um dos fatores, por sinal, que ele lista como maior causador de desinteresse entre os jovem Iny com sua cultura) e segundo também nos relatara (e que fica evidente em nossas conversas) já fora evangélico, uma vez que também é sobrinho de um pastor Iny que lutou pela construção de uma igreja adventista dentro da aldeia Hawalo ${ }^{160}$.

Esra ambiguidade torna este meu amigo um sujeito ainda mais interessante. Jua é um está entre muitos mundos, cohabitando-os. Tal qual um jogador em um campo de futebol, elabora passes, cruzamentos, jogadas e orquestra, de algum modo, - contando com seu talento individual - a sua coletividade. 0 futebol, amiúde, me parece uma metonímia deste processo de negociação cultural sempre fluído, osmótico, em que certos padrões de culturas específicas "jogam” com o "jogo”. Mais do que compreendê-lo sob a lógica de um espetáculo homogeneizador (como, de fato, tantas vezes se apresenta), nas várzeas, nos campos de populações menos abastadas, nas favelas, nas aldeias, nos rincões, é que observamos, de modo mais enfático e em campo, as culturas em jogo.

O que poderia aproximar jovens com a camisa do Barcelona, em Hawalo (que por vezes mal falam o português) de jovens de mesma idade e que vestem a mesma camisa do time catalão, por exemplo, no Paquistão? Talvez a universalidade circunscrita à noção de jogo (e do aleatório), tão evidente no

\footnotetext{
160 Igreja esta que é vizinha a um dos campos de futebol da aldeia e que trata-se de um empreendimento mais recente do que, por exemplo, a missão adventista do 7o dia na aldeia Btoiry (Fontoura) que, segundo Toral (1992), está presente entro os Iny de lá embora de modo intermitente - pelo menos desde 1935.
} 
futebol, possa nos ajudar a mapear alguns destes caminhos. Os times da aldeia Hawalo normalmente são nomeados seguindo referências locais e culturais, trazendo traços de sua "glocalidade"161. Os jovens que dispendem parte do seu tempo em inúmeros campeonatos, parecem fazê-lo com tanto empenho e entusiasmo como quando estão a lutar o Ijesu.

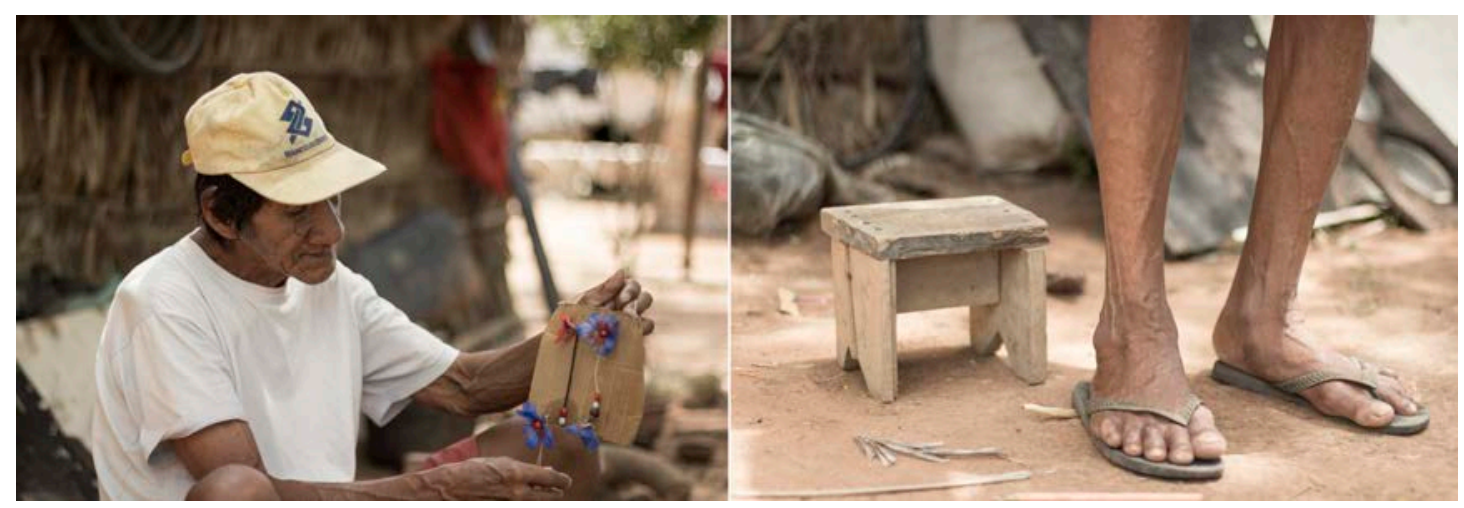

fig. 24 - 0 velho Kurania mostra brincos e artesanatos que confecciona. A foto ao lado mostra o pequeno banco que o homem, de grande sabedoria, costuma se sentar. (Foto: Caio Lazaneo )

O velho Kurania estava sentado em um minúsculo banco de madeira, que contrastava com sua enorme sabedoria. A conversa, em frente a seu hetô, fora muito bonita, tranquila, seguindo o ritmo do velho griô - ainda que em alguns momentos interrompida pelo renitente barulho das onipresentes cigarras que atrapalhavam a gravação do audio. Ouvimos e registramos alguns de seus cantos, e das histórias sobre os mesmos. Embora não compreendamos o idioma, apenas algumas palavras, é possível ver, pelos olhos de Juanahú, quando se conta algo bonito sobre sua cultura.

Uma outra situação, a mim muito cara, tem sido flanar pela aldeia, sendo guiado em suas veredas por Juanahú e, repentinamente, perceber que dentro de algum hetô alguém assiste a "Berahatxi-rbi Olodu Mahadú", o primeiro filme de Jua, que realizamos em Produção Partilhada. Neste dia, em especial, muitas crianças e mulheres se reuniam em frente a uma TV dentro de um hetô da família de Krehalore, primo de Jua. No "altar" dedicado à tv, uma bandeira do Brasil provavelmente um resquício da última copa do mundo de futebol - a sustentava.

161 Tocantis, Hawalo, Estrela do Morro, Escola Maluá, Sol, JK, Kuriala e AIB são atualmente os times da aldeia Hawalo. 

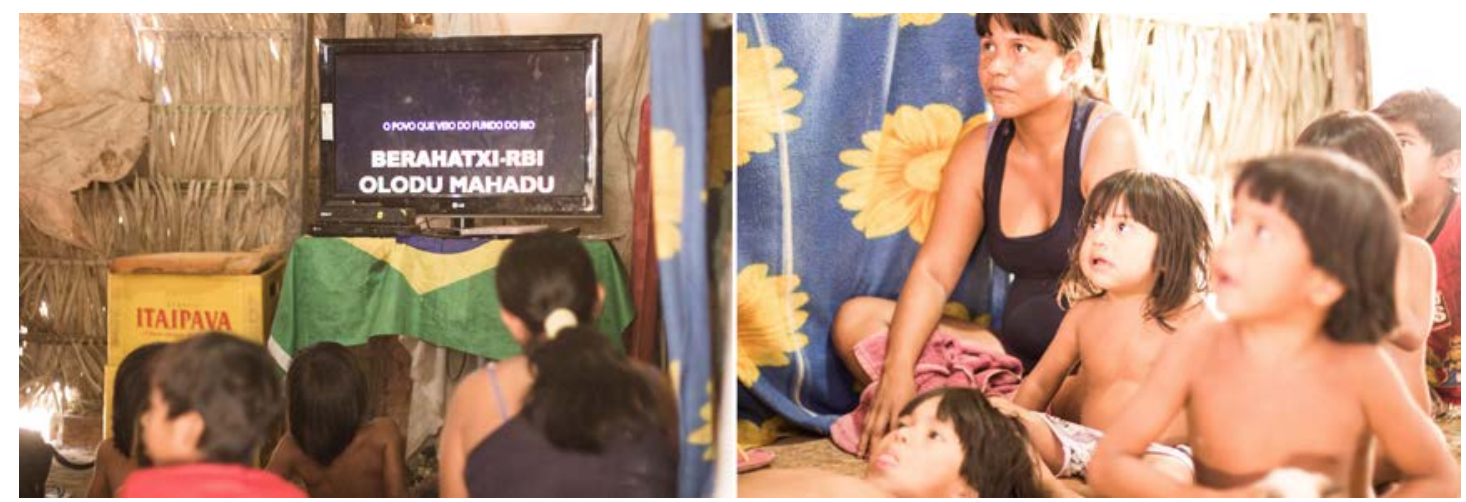

fig. 25 - Crianças e mulheres se reúnem para assistir à Berahatxi-rbi Olodú Mahadu, primeiro filme de Juanahú. (Foto: Caio Lazaneo)

Pela noite, por fim, decidimos registrar uma cena com o intuito de constituir uma espécie de prólogo do filme. Reunimos em volta de uma fogueira Jua e seus filhos, para que Jua lhes narrasse histórias de sua infância, e contasse como eram as festas de Ijasó, o medo enorme de Lateny que o fazia se esconder imediatamente embaixo das esteiras - só de ouvir falar que o mesmo estava andando pela aldeia.

A proposta funcionou muito bem, embora por conta da pouca luz tenhamos planejado regravar o encontro em outro local um pouco mais iluminado. Aproveitamos também para registrar o audio de Mariceru (já que por conta da timidez ela não fosse muito afeita ao registro audiovisual), esposa de Jua, contando, em Iny, o mito Yré, já que segundo Jua ela é uma exímia contadora deste mito o que, de fato, se confirmava pela veemência e entusiasmo ao narrar a história.

Fizemos pela primeira vez uma pausa na rotina de gravações. Pela manhã apenas um breve registro dos filhos de Jua assistindo desenhos infantis na TV. Curiosamente, enquanto os registrava assistindo à animação Tom \& Jerry (desenho clássico, cujo mote é sempre a perseguição de um rato por um gato e, consequentemente, o fracasso do gato na empreitada), o desenho mostrava a invasão de uma terra, pertencente ao rato, por uma dupla de gatos. Um 
cachorro, que aparentemente representava um xerife, repentinamente chegava ao local e, de forma violenta, expulsava os gatos dizendo: "Se eu pegar vocês, gatunos, se apossando da terra de alguém, vou enviar as carcaças de vocês à cadeia, entenderam bem?". De alguma forma o desenho conectava-se com o contexto das terras Iny, assim como de modo geral, com as disputas em torno de terras indígenas no Brasil e no mundo, frequentemente aviltadas por gatunos.

Pela tarde pretendíamos ir à São Félix para comprar mantimentos, no entanto não encontramos barco disponível para a travessia. Ficamos por volta de uma hora sentados à beira do rio aguardando algum barco. É curioso que com esta espera, nós, toris, vindos de uma cidade tão caótica como São Paulo, nos impacientávamos com o fato de não sabermos, ao certo, que horas conseguiríamos pegar o barco. Sinto que olhávamos para o rio e apenas o víamos enquanto travessia. Jua por sua vez, permanecia imóvel, contemplativo, em seu próprio ritmo, um sujeito que sabe observar o tempo de sua terra (e água!), o seu próprio tempo.

Por fim, Juá continuou a esperar por algum barco e nós voltamos ao seu hetô. Com a pausa nas gravações aproveitamos a tarde para organizamos nosso material, lavarmos roupas, etc. Ao fim da tarde jogamos novamente futebol com algumas crianças da aldeia, que parecem se divertir ainda mais quando jogam contra ou com toris.

A noite assistimos nas paredes externas do hetô ao filme "Terra deu, terra come" (2010), de Rodrigo Siqueira. 0 filme é fruto de uma incrível imersão em um povoado quilombola do interior de Minas Gerais e mais especificamente no conhecimento de "Seu Pedro" a propósito do Vissungo, um tipo de ritual fúnebre celebrado por algumas etnias de escravizados trazidos ao Brasil. Neste ser(tão) da oralidade, Jua visualizava semelhanças com a cultura Iny, como, por exemplo, o jarro com água e o prato de comida que é deixado como oferenda ao morto, tradição esta comum a muitas culturas. Iexika, filho mais velho de Juá, parece adorar os filmes que projetamos, já que todos os dias nos pergunta se vamos assistir algum filme a noite. Ele também tem nos auxiliado e acompanhado algumas das gravações, já que Jua pretende que ele venha a ser um futuro "cineasta" e assim faz de tudo para incentivá-lo. 


\section{“Calma que o Brasil é nosso"}

Conheci Divino Tserewahú em 2011, quando demos uma oficina de produção audiovisual para jovens xavante, bororo, kuikuro e kalapalo, em sua aldeia Tsörehípãri (Sangradouro). Desde então nos tornamos grandes amigos (itsiwahwú uptabi) e sempre que nos encontramos damos muita liberdade às brincadeiras, já que Divino é um autêntico auwétoire (em sua língua xavante, um "bincalhão", "palhaço") e eu sempre fui muito afeto ao universo do clown.

Por outro lado, Divino é muito sério e competente quando está realizando um filme. Não canso de aprender com este que "é o maior antropólogo visual do mundo" - como certa vez me dissera o antropólogo Massimo Cannevacci.

Divino costuma distribuir provérbios jocosos, que recolhe e aprende com muitos de seus amigos waradzu (não indígenas). Quando o assunto sugere uma ansiedade logo ele solta, sabiamente, um "calma que o Brasil é nosso", frase esta que em minha leitura sugeria, em um passado recente - de contexto bélico -, paciência uma vez que a hegemonia da pátria seria respeitada. Sempre que o escuto dizê-la, penso o quanto soa, de forma cortante, um tanto paradoxal. Infelizmente não sei o quanto o Brasil tem sido "nosso" no tocante à situação indígena. Alguns povos continuam marginalizados às beiras de rodovias, como o urgente e trágico caso dos Guarani Kaiowá no estado do Mato Grosso do Sul.

Projetos faraônicos continuam a ser tocados por um estado insensível à questão indígena, como o caso da hidrelétrica de Belo Monte, no estado do Pará, que afetará todo o regime do Rio Xingú, de suma importância para as 13 etnias do parque indígena de mesmo nome. De fato, o Brasil parece um país completamente distante da imensa maioria dos indígenas que, ao mesmo tempo, parecem estar longe de poderem ser chamados de "brasileiros" (um imaginário de nação e de identidade tão distante da realidade das aldeias).

De algum modo, o provérbio tão repetido por este sábio amigo poderia também sugerir a virtude da paciência, uma vez que o Brasil poderia ser dos indígenas, já que sempre fora assim (muito antes da chegada dos colonizadores), e temos muito o que aprender com esta "calma", com esta compreensão de mundo. 
Divino e eu vínhamos nos falando com frequência nos últimos dias e aproveitei para convidá-lo a ajudar-nos na realização do filme na aldeia Hawalo, já que também havíamos trabalhos juntos no primeiro filme de Jua - "Berahatxirbi Olodu Mahadú". Na sexta-feira, por volta do meio-dia, ele chegou para integrar a equipe por 3 dias, já que na segunda, deveria estar de volta à Primavera do Leste, por conta de compromissos de trabalho.

Sua chegada trouxe um misto de otimismo e dinamismo à equipe. É visível que Juanahú se sente ainda mais seguro com a presença do colega. Pela tarde, já contando com a ajuda de Divino, finalmente filmamos a festa de Ijadoma (moça). Nela, a filha do cacique Idiarrina, que há pouco tivera sua primeira menstruação (e por isso se encontrava reclusa), recebeu um corte de cabelo tradicional Iny (que consiste em fazer uma espécie de "penacho", cortando um punhado de cabelo da parte superior de trás da cabeça e emplastrando-o com cêra), feito por sua madrinha, que depois o fez em sua mãe e sua mãe, por sua vez, na madrinha.

Antes disso, porém, algumas das mulheres circularam pela aldeia oferecendo com sete tigelas de alimentos (frutas, pipoca, balas, bolachas, salgadinhos), oferecendo-os em algumas casas específicas. Findo o corte do cabelo da menina, da madrinha e da mãe, uma anciã escolhida pelo pai se dirige à menina e a alimenta na boca. Logo após, novas (e enormes) bacias contendo principalmente pipoca, salgadinhos e bolos são partilhadas com todos os presentes e as mulheres, eufóricas, enchem sacolinhas com os alimentos, enquanto as crianças disputam seus quinhões. Tudo de forma muito rápida e quase coreografada (esta etapa do ritual deve ter levado em torno de 50 minutos).

A situação me remeteu ao ritual Wapté Mñoño (iniciação do jovem), que acompanhei entre os xavante, onde também há uma oferta de alimentos por parte das famílias dos wapté (jovens) e a mesma era recheada de muita comida de waradzu / tori (dos não indígenas), como no caso Iny. Por fim, como é de praxe, a situação se mostrou bastante complexa para um registro audiovisual, com uma quantidade excessiva de informação acontecendo ao mesmo tempo, embora eu acredite que nosso registro tenha sido suficiente. Pela noite, para celebrar a chegada de nosso colega, assistimos ao filme " 0 mestre e o Divino", um ótimo documentário dirigido por Thiago Torres, cujo 
protagonista é Divino Tserewahú e o mestre salesiano Adalbert Heide, retratando a curiosa relação de ambos.

“Quando se pede um empréstimo, é preciso saber honrá-lo", era o que dizia, em seu sermão, um jovem (que substituía o pastor, de férias), na manhã do sábado, em frente ao púlpito da Igreja Adventista presente na aldeia Hawalo. Esta fora a segunda vez, em pesquisa de campo, que pude acompanhar um rito cristão acontecendo dentro de uma aldeia. A primeira fora na missão salesiana entre os xavante de Sangradouro. Confesso que, por conta de meu posicionamento, esta é, para mim, uma situação sempre um tanto difícil. Não apenas no sentido crítico à lógica do colonialismo religioso que é, de fato, tantas vezes extremamente nocivo à cultura ameríndia (embora tenha percebido, entre os xavante, por exemplo, uma tática contra-hegemônica que não pode ser entendida apenas na lógica de uma simples "submissão"). Nem, tampouco, de atribuir aos Iny "convertidos", uma passividade subalterna. Mas, sobretudo, de tentar entender como, no âmbito institucional, o estado brasileiro se mostre tão negligente ao ponto de, na sua ausência, incentivar a entrada desenfreada de missões cristãs em terras indígenas, algo que ainda vem acontecendo em pleno século XXI (há relatos de aldeias guarani, por exemplo, que possuem quatro igrejas evangélicas, de diferentes segmentos, no mesmo território).

É inevitável que essas instituições, em uma constante tentativa de sobrepor camadas da cultura nativa de modo a se estabelecer no topo da mentalidade ameríndia - enquanto principal referencial -, não façam estragos pelo caminho. Jua, que é sobrinho de um pastor adventista Iny, algumas vezes nos sugerira uma leitura da cultura do Aruanã (ou os espíritos Ijasó) como sendo algo próximo do "satanás". Essa toada "demonizadora" é mais frequente sobretudo entre os evangélicos, uma vez que os católicos, desde concílio II do Vaticano, mudaram sua estratégia de conversão, tornando-a mais sofisticada, incluindo no imaginário cristão aspectos da cultura local (e vice-versa) - neste caso com o claro objetivo de "facilitar" a entrada da "palavra evangelizadora".

É curioso observar nos católicos de Sangradouro, por exemplo, os cânticos na língua nativa, além do crucifixo central na igreja onde o Cristo veste 
uma gravatinha típica dos xavante. Já a Igreja Adventista da aldeia Hawalo, pareceu-me mais "padronizada", embora sua fachada apresentasse alguns grafismos Iny na parede.

Por sua vez, os cânticos também não eram em língua nativa, mas em português, sendo reproduzidos juntos à clipes bastante toscos, em um telão central. 0 jovem, substituto do pastor, enquanto mestre de cerimônia, cantava ao microfone (um típico playback - por cima das músicas já gravadas), com uma entonação quase caricata. Jua, do lado de fora, estava bastante animado enquanto fazíamos os registros tanto internos quanto externos da igreja.

A mesma, no entanto, não estava lotada, sendo possível notar lugares vazios. Os Iny presentes eram algo próximo a 30, mas com frequência, e sem aviso, alguns saíam e outros entravam. 0 jovem substituto do pastor não falava a língua Iny, e todas as vezes que necessitava da leitura de algum trecho bíblico, solicitava a um rapaz local que o fizesse na língua, pelo microfone.

Durante os cânticos, os Iny pareciam enfrentar alguma dificuldade linguística (e quiçá rítmica), já que pouquíssimos cantavam. Por conta sobretudo do público formado em número maior por mulheres e crianças, sai do evento matinal com a impressão de que, neste contexto, talvez a igreja não seja um dos principais fatores para o esvaziamento da festa de Aruanã (organizada principalmente pelos homens), embora contribua, no imaginário, para uma cultura de desinteresse para com os rituais Iny.

Pela tarde, logo após o almoço, entrevistamos Iwraru, cacique da aldeia Ataú (bastante próxima de Hawalo), a fim de captarmos sua opinião sobre a hipótese de Juanahú (e do filme) a propósito do contínuo abandono da festa de Ijasó (Aruanã).

O consumo de álcool, a entrada cada vez mais incisiva de hábitos dos toris (futebol, televisão, etc) seriam fatores que contribuiriam com o arrefecimento da festa? Sua opinião endossava essa hipótese. Iwraru, neto do famoso líder Iny Ataú, é uma conhecida liderança que participa com frequência da vida política Iny, mas que também se aventura na política "fora" da aldeia, tendo sido eleito vereador no município de Lagoa da Confusão, em 2012.

Além de cacique, Iwraru é um grande compositor, assim aproveitamos a entrevista inclusive para registrar alguns de seus cantos. Talvez também por 
conta de seu trânsito fora da aldeia, Iwraru costuma apoiar projetos que envolvem alguma polêmica, como a extensão da BR-242 cruzando a Ilha do Bananal, embora outras lideranças que permanecem mais na aldeia também apoiem projetos dessa magnitude.

Temo que a pavimentação e abertura dessa futura estrada represente para os povos da Ilha do Bananal algo semelhante (em diferente escala) ao que vai representar a faraônica usina de Belo Monte para os povos do Xingú. Embora muito próximo de Iwraru e de outras lideranças favoráveis à construção da rodovia, Juanahú é completamente contrário ao empreendimento, com uma leitura bastante lúcida de que, inevitavelmente, a rodovia acentuará ainda mais alguns dos problemas pelos quais passam os Iny.

Por parte do estado - sempre nutrindo de desinteresse no tocante às questões indígenas - a justificativa para a construção parece seguir os ditames do "progresso" à moda brasileira (em curso desde a chegada dos portugueses): É urgente derrubar florestas para construir estradas, sobretudo para escoar a soja que, para seu plantio, por sua vez, já desmatou outras tantas terras mais. Assim como, no Rio Xingú, era "urgente" a construção de uma faraônica usina hidrelétrica (que - embora quando pronta venha a ser a terceira maior do mundo - praticamente não funcionará por 4 meses no ano, durante o período de estiagem), mudando o regime de um rio e afetando toda a fauna e flora locais, além de intervir substancialmente nas práticas dos povos e comunidades que habitam a região. À algumas instituições cristãs, parece ser "urgente" suplantar a compreensão de mundo do indígena, da "inconstante alma selvagem", do universo mitológico que consideram como "primitivo", "bestial".

Neste sentido é possível retomar a reflexão inicial a propósito da leniência do estado no tocante a entrada desenfreada de igrejas em terras indígenas. Enquanto este perpetua seu ideal de "progresso", em uma disputa geográfica e econômica, as igrejas "cumprem o papel" de tentar esvaziar o sentido das práticas rituais ameríndias, de preferência demonizando-as. Assim, consolidam uma dupla atuação eficiente, "progressiva", em uma incursão de “desapropriação” territorial, ideológica e cosmológica dos povos indígenas.

Finda a entrevista com Iwraru, fomos à São Félix a fim de comprarmos mantimentos. É curioso notar que embora estejamos em plena Ilha do Bananal, 
com o imenso Rio Araguaia a uma curta distância da aldeia, os Iny parecem muito propensos a acrescer ao hábito de comer peixes, o consumo substancial de outras carnes (principalmente de ave e bovina). Embora estejamos em época de cheia do rio, o que evidentemente dificulta a pesca, durante os dias que estamos na casa de Jua, por exemplo, não chegamos nem sequer perto de saborear um bom peixe e na lista de compras elaborada por sua esposa Mareciru - do que deveríamos trazer da cidade -, enquanto proteína, somente constavam carne de boi e ave.

Percebo que a pesca inclusive costuma ser um tema jocoso, sobretudo entre os homens adultos. É comum que quando um Iny deseje de certo modo "desqualificar" um colega (sugerindo que ele seja mais tori do que iny), faça piadas sugerindo-o enquanto um mau pescador e caçador. Juanahú, que trabalha na cidade e é entusiasta das câmeras fotográficas e filmadores (práticas atribuídas mais aos não indígenas), é um alvo frequente.

Pela manhã nos encontramos com Waxiaki, uma simpática prima da esposa de Jua. Waxi estudou pedagogia em São Paulo e é um exemplo, um tanto raro, de mulher Iny que saiu da aldeia para estudar (sendo algo mais comum entre os homens) e hoje trabalha na escola local.

É também frequentadora assídua da Igreja Adventista da aldeia e, a nós, interessava muito coletar seu ponto de vista a propósito da relação entre um potencial conflito da teologia cristã com a "religião" dos Iny. Já imaginávamos, no entanto, que seu ponto de vista não seria crítico a esse propósito, o que se confirmou com a entrevista.

Segundo nos relatara Waxi, a igreja seria uma oportunidade ao jovem Iny que desejasse seguir um caminho mais "sério" e não simplesmente perambular pela aldeia, jogando futebol e perdendo o tempo com cachaça e afins. Do mesmo modo, Waxi nos confirmou algum desinteresse pelo modo de vida ritual, sobretudo pela festa de Aruanã (Ijasó) e o Hetohoky. Como uma espécie de denegação, à medida em que afirmava que as práticas adventistas não seriam motivo para o "esquecimento" da vida ritual tradicional, de algum modo sugeria 
o mesmo. 0 fato é que, aliado a esse desinteresse, Waxi incorporou novos hábitos a seu cotidiano, como por exemplo a ideia de transformar seu hetô em uma espécie de lanchonete, com venda de lanches, pastéis, bolos e refrigerantes.

Após a entrevista, por sinal, provamos seu pastel, bastante apetitoso. A venda de refrigerantes é algo bastante disseminado em aldeias com contato mais frequente com a população não indígena, o que evidencia a urgência de se observar o alto índice de diabetes entre as populações indígenas, que, de modo geral, é substancialmente agravado pelo metabolismo pouco habituado ao açúcar. Certa vez, em São Paulo, conheci o Dr. João Paulo de Arruda Botelho médico e professor da Unifesp especialista na questão da diabetes - que desenvolve um amplo trabalho com populações indígenas e que me alarmara para o fato de que, em algumas aldeias que atende, o índice de diabéticos chega a ser de 70\%. À época registrei, a seu convite, um depoimento com o kayapó Bepkamerék - alertando para os perigos do açúcar -, na língua xikrin-kayapó, a fim de que ele distribuísse o vídeo entre seu povo.

Após a entrevista - conversando com Waxi - pela primeira vez escutamos (de um modo mais incisivo) um Iny desqualificar a hipótese de "feitiço" constantemente atribuída ao grande número de suicídios que vem acontecendo desde 2010 em diversas aldeias. Waxi dizia que, em sua leitura, a ideia de feitiço seria "bobagem", apenas uma "crendice", naturalmente embasada por sua afeição à doutrina adventista.

Pela tarde, resolvi propor o registro de um diálogo entre Juanahú, Divino e eu. A ideia, de forma abrangente, era de que conversássemos sobre a Produção Partilhada (já que nós três, junto ao nosso grupo na USP - CEDIPP - temos há algum tempo desenvolvido esta proposição a partir do audiovisual e hipermídia) e, também, pensarmos conjuntamente ideias para o filme que estávamos gravando.

No entanto, ao mesmo tempo, de minha parte não havia o desejo de sugerir um argumento retórico a fim de conduzir deliberadamente o diálogo (e que deste modo não seria propriamente um diálogo). Assim, expus a ideia inicial e a conversa se desenrolou durante 50 minutos, com falas principalmente de Divino e Juanahú. Como de praxe, Jua fez uma longa introdução sobre seu início no audiovisual. Divino por sua vez citou resumidamente sua experiência, 
lembrando também das semelhanças nos percursos da realização de um filme entre os xavante e os karajá (as dificuldades ao lidar com o desinteresse dos jovens, sobretudo pela questão do álcool).

Após algum tempo, porém, o assunto deu uma ligeira guinada, sobretudo na fala de Divino que passou a cobrar soluções - do ponto de vista financeiro para que os trabalhos que envolvem a "Produção Partilhada" sejam contínuos, crítica esta que aceito e compartilho, embora com frequência eu lhe explique que, no contexto acadêmico, dependemos de uma série de instituições e apoios e que esses trâmites nunca se dão de forma simples.

Reconheço que o discurso de Divino transpassa uma necessidade de segurança com a qual ele ficou habituado durante o período em que trabalhou junto ao VNA (Vídeos nas Aldeias) ${ }^{162}$. O VNA, embora seja uma ONG que habitualmente lide com dificuldades para encontrar apoiadores e patrocinadores a fim de cooperar no desenvolvimento de seus projetos, conseguiu por um tempo considerável criar condições muito profícuas de trabalho com diversas etnias e o que é de suma importância - capitaneando verbas para tanto a partir de uma rede muito atuante.

Assim, embora Divino reconheça a relevância dos trabalhos em Produção Partilhada já desenvolvidos (e valorize - dentro deste contexto -, por exemplo, a ida de grupos xavante à Universidade de São Paulo, bem como os filmes já realizados), é natural que sinta por vezes a falta de apoio financeiro (para a continuidade de determinados projetos), sobretudo tendo ficado mais de dez anos dentro do VNA ${ }^{163}$. Esta reflexão de Divino é bastante oportuna (e recorrente). Deste modo, acredito que temos de continuar tentando criar condições possíveis e interessantes, mutuamente, para os trabalhos que envolvem Universidade e Comunidade.

Ao fim do dia fomos à aldeia $\mathrm{JK}$ a fim de entrevistarmos o cacique Paulo Krumari. Ele, também evangélico e frequentador assíduo da igreja adventista.

\footnotetext{
${ }^{162}$ Sobre um resumo das atividades do Vídeo nas Aldeias, Cf. CARELLI, Vincent, GALLOIS, Dominique. Vídeo e Diálogo Cultural - Experiência do projeto Vídeo nas Aldeias. Horizontes Antropológicos, Porto Alegre, ano 1, n. 2, p. 61-72, jul./set. 1995 ${ }^{163}$ Após o tempo de formação no VNA (tendo realizado neste período 7 filmes), Divino deixou o projeto para trabalhar no Museu Comunitário de sua aldeia - que é vinculado ao Museu das Culturas Dom Bosco (de Campo Grande) e que, por sua vez ,é mantido pela UCDB (Universidade Católica Dom Bosco).
} 
Interessava-nos seu ponto de vista a propósito do paulatino abandono da festa. Curiosamente Krumari vestia uma camiseta com os dizeres "Ousider". Aquilo me fez refletir novamente sobre os arranjos e montagens do acaso. Em sua fala, assumia seu desinteresse pela tradição Iny o que, de alguma forma, corrobora com a hipótese de que o imaginário adventista, como presumível, contribui para o abandono de algumas práticas, em nome de, segundo ele, um caminho de "Deus" (oposto ao dos espíritos Ijasó). Endossou também que, não fosse pela igreja, estaria condenado à morte, já que estava "perdido" na bebida.

Sua casa, à beira do rio, parece-se bastante com um rancho ribeirinho (uma casa com uma arquitetura bastante comum - que não lembra em nada os hetôs Iny - e que poderia estar situada à beira de qualquer rio no Brasil central), no entanto, o pôr-do-sol visto a partir dela é um espetáculo à parte. Por sua posição geográfica (na aldeia JK), é possível ver o rio Araguaia engolindo o sol (o que não é, possível, por exemplo, de Hawalo).

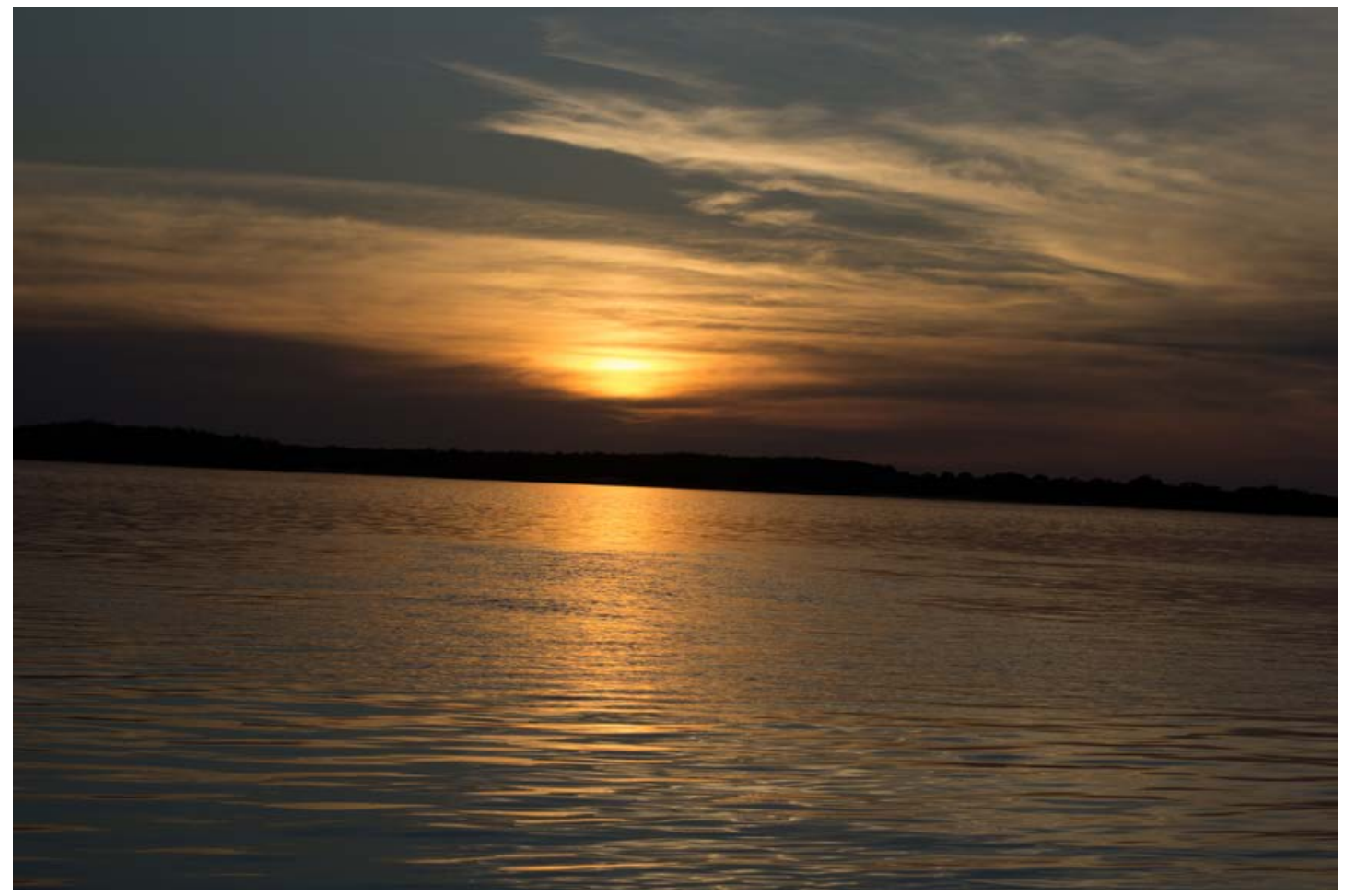

fig. 26 - Pôr-do-sol da Aldeia JK, Ilha do Bananal. (Foto: Caio Lazaneo)

\section{"Eu ando respeitando a cultura"}


Pela manhã nos despedimos de Divino que voltaria à Tsörehípãri. Pela tarde um forte temporal caiu na aldeia e não pudemos fazer nada a não ser, de dentro do hetô, esperarmos a chuva passar. Com o tempo melhor, propus que registrássemos uma conversa entre a equipe em que pudéssemos refletir sobre o trabalho desenvolvido até então e sobre como pretendíamos continuá-lo.

A conversa fluiu muito bem, de forma que pudemos inventariar o que até então havíamos registrado e, de modo especulativo, pensar nos pedaços ainda necessários ao encaixe dos filmes. Jua, por sua vez, revelou uma certa "trapaça antropológica". Sem conseguir esconder o riso que lhe é habitual, revelara que, desde meados do ano passado, em nossos primeiros contatos telefônicos e conversas a partir da ideia de realizar um filme sobre os Aruanãs, vinha de certo modo me enganando ("Para deus a gente não pode mentir, mas para o Caio eu tava mentindo", disse ele).

Sempre que eu lhe perguntava como estavam os preparativos para a festa na aldeia ("Tem Aruanã aí?"), Jua me respondia: - Tem sim, está tudo bem waxerioré!164 Muitas foram as vezes que ele - agora confessando - dissera-me que tudo transcorria bem porque pressupunha que se o diagnóstico mais próximo do que de fato acontecia (ausência de Aruanãs) na aldeia me fosse transmitido, eu declinaria ao convite.

Vínhamos conversando pelo menos desde agosto de 2014 sobre a ideia de desenvolvermos novos trabalhos em Produção Partilhada, em especial na aldeia Hawalo (com a possibilidade de realizar uma cartografia fílmica dos Aruanãs) e, da minha parte - quando pedia que Juanahú contasse sobre como estavam os preparativos na aldeia - a intenção era fundamentalmente propiciar um diálogo em que ele, enquanto interlocutor da comunidade, pudesse pensar as possibilidades fílmicas a partir de sua leitura no local.

Na cabeça de Jua, me parece, passava um dilema entre qual seria o filme (idealizado) que interessaria a este novo encontro, quando na verdade estava testemunhando conflitos pelos quais a aldeia passava e que, de certo modo, o guinavam para uma outra perspectiva. Ao insistir em sua "trapaça", ainda à distância, afirmava a mim uma possibilidade de realização de um filme sobre a

${ }^{164}$ Em iny $=$ irmão 
festa de Aruanãs (Ijasó) transcorrendo em perfeita "harmonia", com a comunidade efetivamente participando das festividades, o que, em campo, percebemos que se mostrava bastante nebuloso. Compreendo seu movimento como um duplo vínculo: Ao passo que Jua vê, de alguma forma, negado seu "ritual idealizado", passa a insistir (para mim) na idealização do mesmo, acreditando que, em algum momento, este se repetiria tal qual em suas memórias de infância e adolescência.

Ao mesmo tempo, parece-me, na perspectiva de uma troca simbólica, esta trapaça, da parte de Jua, se justificaria enquanto um "engodo antropológico" reforçando que um determinado imaginário - sobretudo acadêmico - estaria habituado a seduzir-se por aquilo que as culturas ameríndias teriam de mais "genuíno", ou seja, suas diferenças. Assim, um "autêntico" ritual Iny seria muito mais "proveitoso", para fins de pesquisa, do que um ritual "problemático". No entanto, em minha perspectiva, nunca houve (e nem poderia haver) um pressuposto idealizado sobre o que encontraríamos ${ }^{165}$ em campo, em situação de pesquisa.

A ideia de trabalhar com a festa de Aruanã partiu sempre de uma sugestão de Jua que é quem, em última instância, poderia eleger o que interessaria a si, enquanto interlocutor, e à comunidade enquanto de algum modo também protagonista da pesquisa (e consequentemente do filme). Para nossa surpresa, o duplo vínculo de Jua permanecia também em sua relação com a dicotomia introduzida pela teologia cristã, onde ele, em sua leitura afirmava, haveria apenas dois caminhos possíveis: o de deus e o de satanás. Nesse binarismo pouco generoso, é fácil imaginar qual é o lugar reservado às manifestações tradicionais dos Iny, bem como o lugar do hyri, chefe espiritual,

1650 que potencialmente iria contrariamente a algo que nos interessa, do ponto de vista metodológico no horizonte da pesquisa-ação, que é justamente assumir o "inesperado" em campo, ou seja, compreendê-lo como substrato fundamental de uma Produção Partilhada, onde não só os sujeitos diretamente envolvidos na pesquisa manifestam-se de maneiras tantas vezes imprevisíveis, bem como o entorno que determina estas relações (aqui inexoravelmente a relação universidade-comunidade). Thiollent (2011) afirma que na pesquisa-ação estamos sempre sujeitos a "[...] interação de grupos sociais no qual se manifestam muitas variáveis imprecisas dentro de um contexto em permanente movimento". (p. 40) 
naturalmente "condenados" como o "caminho do satanás". Aqui mais uma vez o comportamento contraditório assumia, em Jua, uma face complexa e sedutora.

Seria como imaginar um sujeito praticante do candomblé que, sendo também evangélico, dedicaria enorme respeito, admiração e empenho em registrar (e produzir filmes!) sobre os rituais do candomblé, embora supostamente acreditando que este representaria o "caminho ruim". A própria recusa em assumir definitivamente essas determinações, me parece, reafirma o que há de mais interessante no perspectivismo, ou seja um anticartesianismo (circular) que a todo momento luta contra certas convenções ocidentais, fundamentadas em tipificações binárias.

Em suma, Jua dizia analogamente que todo sujeito tem duas pernas e assim deve definir um caminho, um curso, compreendendo assim que haveria um caminho "do bem" e um caminho "do mal" (provavelmente muito influenciado pela fala de Paulo Krumari no dia anterior). Ao mesmo tempo nenhuma de suas práticas parecia sugerir que ele acreditaria substancialmente nessa compreensão. Conforme assumia, já havia sido evangélico (batizado por seu tio, pastor adventista) e conhecia o que seria o "caminho de deus", embora não fosse mais assíduo da igreja. Não obstante, solicitava a seu tio: "Ore por mim". "Eu ando respeitando a cultura", fora uma de suas frases que, para mim, mais marcaram (neste diálogo) sua singular compreensão. Respeita a qual cultura? Iny? Tori? Adventista? Andar, verbo intransitivo, traduz em Jua sua circular (e respeitosa) caminhada, sua perene dúvida o coloca sempre, para além de todo binarismo redutor, na terceira margem do rio. 


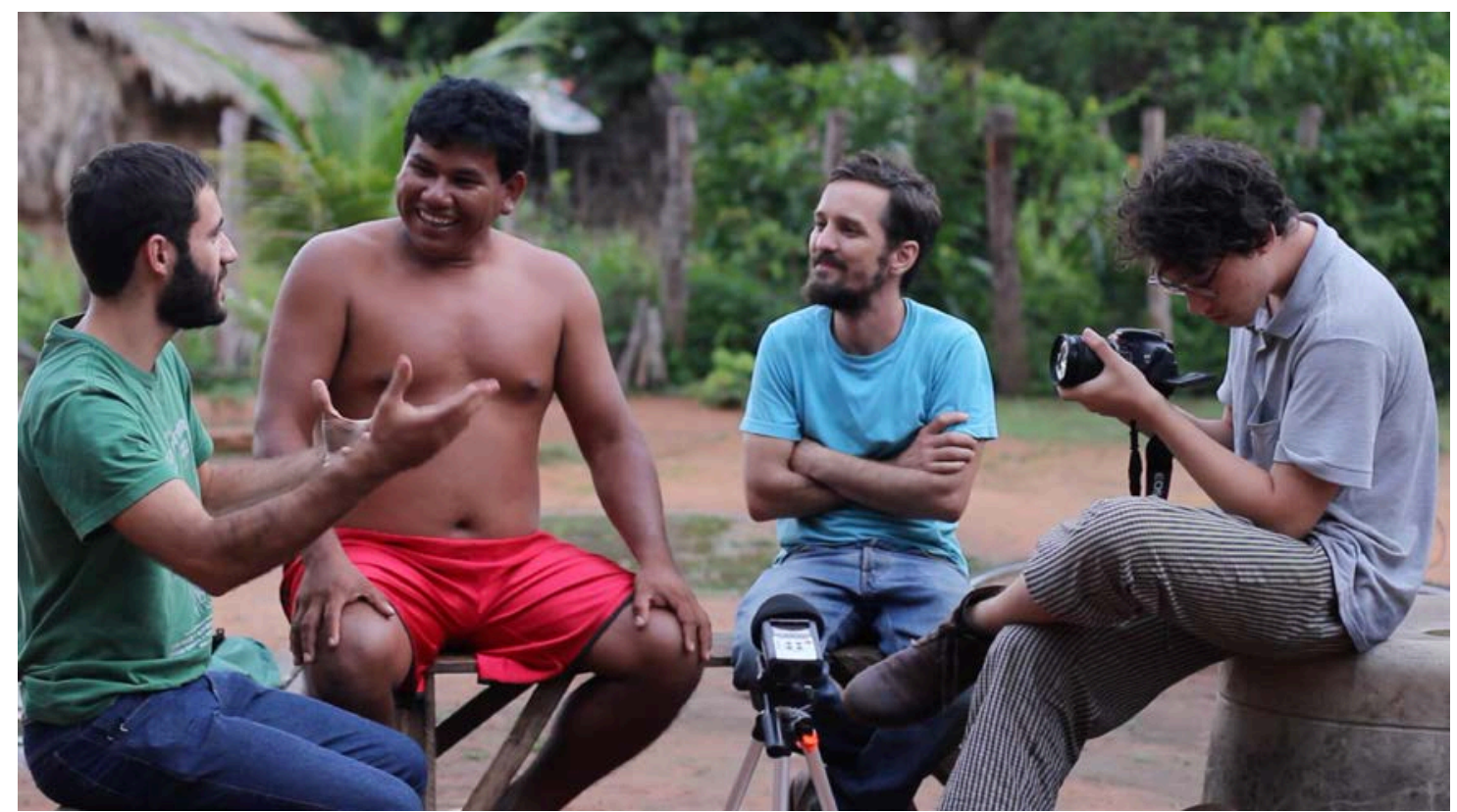

fig. 27 - Da esquerda para direita: Caio Luiz, Juanahú, Caio Lazaneo e Yudji Oliveira. Conversa da equipe sobre o filme em andamento (still retirado de audiovisual).

Pela manhã, durante o café, decidimos (toda a equipe) iniciar novos registros paralelamente aos que fazíamos sobre a festa de Aruanã. A ideia seria realizar um curta documentário sobre a questão do suicídio entre os jovens Iny. 0 assunto se manifestara espontaneamente em muitas das conversas desde a nossa chegada. Assim, contando com o aval e interlocução de Jua, pensamos na realização deste possível filme, acrescentando que procuraríamos colher as entrevistas em língua portuguesa (portanto privilegiando interlocutores que a falassem), para que, desta forma, o filme / documento pudesse chamar atenção de forma mais disseminada (sem barreira linguística aos lusófonos) e, assim, pela urgência que o tema enseja, não depender do considerável tempo dedicado ao trabalho de legendagem.

Gravamos uma primeira entrevista com Axiawá, irmão de Waxiaki, com quem havíamos conversado dois dias antes. 0 jovem iny (de 27 anos) cursa Licenciatura Intercultural (com ênfase em Ciências da Natureza) ${ }^{166}$, na Universidade Federal de Goiânia, e tem um exímio domínio da língua portuguesa.

166 Durante o diálogo, Axiawá nos contara que seu trabalho de pesquisa em curso na graduação era dedicado a estudar o choro ritual de lamentação (ibrohoky) na sociedade iny. 
Em uma direção diferente de sua irmã, Axiawá valoriza sobremaneira as especificidades da cultura iny. As casas do dois irmãos, que ficam praticamente uma em frente a outra, são cortadas pela estrada de terra que, nesta extremidade da aldeia, é um dos caminhos para JK. O contraste é evidente, enquanto a moradia de Waxiaki é já edificada em alvenaria (e conta com um cardápio com oferta de pasteis, bolos e refrigerantes, pendurados em uma árvore logo em frente à fachada), a casa de Axiawa, recém-construída, segue os moldes tradicionais das moradias iny. Imerso em sua infinda pesquisa pela cultura iny, Axi propõe hipóteses e descrições acerca dos rituais (aqueles ainda "vivos" e aqueles em vias de extinção) e constrói assim, uma autêntica interdisciplinaridade.

É o caso de uma antropologia reversa, em que a pesquisa legitima a perspectiva do próprio insider, em um contexto em que, felizmente, ao passo que novas epistemologias conseguem ganhar voz na academia, a mesma com enorme frequência solapa os saberes locais. Axiawa citou os vários choros por ele encontrados (e catalogados) como o choro da passagem do jovem para a adolescência (choro do menino), o choro da menina (quando da primeira menstruação), o choro "identitário" (quando é realizada a escarificação circular facial característica do povo iny), o choro do "corredor / guerreiro" e, por fim, o choro funeral. Segundo Axiawá, os Aruanãs representariam o espírito do "povo submerso", protetores dos iny diante das "coisas perigosas". Analogamente dizia que enquanto os toris "oram" para pedir proteção, os iny a pedem aos Aruanãs, fazendo-lhes oferendas.

Os aruanãs em síntese são os protetores da sociedade iny. A propósito da luta Ijesu, Axi dizia haver diferentes nomes a cada um dos golpes empregados (assim como diferentes "usos" da luta) e que, assim, não se tratava de uma simples brincadeira. Realmente em todas as oportunidades que a acompanhei mais de perto, sempre chamara atenção uma técnica bastante apurada entre os oponentes (além de uma singular ridicularização na provocação que os mesmos faziam antes e depois da luta entre os próprio combatentes). 
Sobre o suicídio, Axi dizia: "É difícil dar uma resposta definitiva". Porém acreditava que o egoísmo, de certo modo alastrado entre os jovens, poderia ser um dos fatores: "Os adolescentes estão se achando demais". A vida em comunidade estaria se tornando - segundo ele - visivelmente mais individualizada em detrimento do coletivo. Da mesma forma acreditava que a hipótese de um feitiço (que estaria de modo generalizado e fora de controle) recaindo sobre as comunidades Iny não poderia ser afastada, assim como o fato de que o consumo de bebidas alcoólicas, açúcar e sal sempre crescente, estaria provocando terríveis desequilíbrios, sobretudo entre os jovens.

Citou também que "antigamente" até mesmo os jovens tinham suas chefias - dentro de seu grupo -, cuja representação "criativa" era respeitada (os jovens deveriam sentir-se "atraídos" por essa liderança), mas que hoje esse lugar fora praticamente abandonado. A uma certa dicotomia sedutora, a um certo híbrido entre feitiço e fetiche (causa de um mal maior), Axi sugeria: "Em qual conhecimento vamos gastar energia?"

Referia-se portanto aos conhecimentos iny e tori, indígena e não indígena, que em tantas circunstâncias parecem competir mais do que somar. É fato que os iny têm contatos mais ou menos frequentes com a sociedade não indígena desde pelo menos o século XVII, no entanto, sobretudo na última década, este contato passou a intensificar-se cada vez mais, principalmente pelo acesso à novas tecnologias como a televisão, celular, internet, etc. Se até a pouco tempo a aldeia ficava às escuras a partir da sete horas da noite, com alguns poucos geradores (particulares) disponíveis para usos específicos, hoje em dia a energia chega a praticamente todos os hetôs.

Uma cena bastante comum que pode ser observada em Hawalo é o contato diário das crianças (e não só) com a televisão, a qual tenho ligeiramente a impressão de estar ligada a todo momento. No hetô de Jua, por exemplo, é raro que o aparelho fique desligado, o que normalmente somente acontece durante a noite, quando todos vão dormir. Não interpreto (e não atribuo) aqui uma exclusividade deste desequilíbrio (notado e enfatizado com frequência por muitos iny) tão somente aos dispositivos eletrônicos e as tecnologias, esta interpretação seria inclusive incoerente com nossas propostas. Acredito que até mesmo a televisão - tão citada - naturalmente encontra grande simpatia entre os 
iny, pois lida com signos caros às comunidades de tradição oral, quais sejam as matrizes sonoras e visuais.

No entanto é notório que três fenômenos importantes coincidem ao menos nos últimos dez anos nas comunidades Iny da Ilha do Bananal: 1. Intensificação do contato com dispositivos eletrônicos tais como aparelhos celulares, televisores, computadores, etc, sobretudo a partir da chegada da luz elétrica através de programas governamentais como o "Luz para todos"167. 2. Desinteresse crescente dos jovens iny nas práticas rituais tradicionais como o Hetohoky ${ }^{168}$ e 3 . Alto índice de suicídio, com enorme incidência entre jovens menores de 18 anos.

Dada a extrema complexidade que o tema envolve, temos tido enorme dificuldade de encontrar estatísticas oficiais que nos apresentem números mais precisos. Ao mesmo tempo, o luto que frequentemente envolve a comunidade ${ }^{169}$ que com perplexidade enfrenta a morte de seus jovens envolta em enorme dor, nos implica a delicadeza necessária para evitar qualquer abordagem mais "objetiva”. Por vezes em um diálogo com algum interlocutor, a conversa subitamente toma outro rumo e, respeitosamente, é melhor que assim o seja.

De acordo com o relatório da OMS (Organização Mundial da Saúde) "Preventing suicide: A global imperative”, de 2014, a taxa de suicídios no mundo, no ano de 2012 (em análise no relatório), fora de 11,4 casos para cada grupo de 100 mil habitantes (totalizando 804 mil casos). O último censo da Funasa (Fundação Nacional da Saúde), de 2010, aponta que os iny possuem uma população de 3.198 habitantes. Os dados colhidos a partir de relatos - portanto extraoficiais - dão conta de ao menos 25 casos de suicídios nos últimos 10 anos em aldeias iny, embora a imensa maioria tendo ocorrido nos últimos 5 anos (talvez teriam sido apenas 6 os casos antes dos últimos 5 anos). Assim, mesmo se levarmos em conta os últimos 10 anos, é possível estimar que o índice de

167 Isto circunscrito às aldeias karajá da T.I Parque do Araguaia onde a chegada da luz elétrica (através de implementação governamental) se dera muito recentemente. Em outras aldeias karajá, como Buridina, município de Aruanã - GO, este processo ocorreu há mais tempo por conta de uma maior proximidade com o contexto urbano.

168 Diferentes relatos dão conta de que até 2003, por exemplo, o ritual ainda despertava enorme atenção e participação de toda a(s) comunidade(s) envolvida(s), o que sucessivamente, ritual após ritual, vem se arrefecendo.

169 Os últimos suicídios ocorridos em aldeias iny, aconteceram logo no começo do ano de 2015, ou seja, poucos dias antes de nossa chegada. 
suicídio, entre os iny, seja de quase 7 vezes maior do que a média mundial, um número extremamente preocupante para uma população pequena.

Por fim, pela tarde, tomamos um divertido banho no rio junto às crianças iny que surgiam por todos os lados. Embalados por suas brincadeiras subimos várias vezes no alto da chalana da aldeia (ancorada na margem) para mergulharmos no Araguaia.

Decidimos aproveitar a ida à São Félix para encontrar com Kohalue, iny chefe de posto da Funai na cidade. A caminho da margem para esperarmos a voadeira (lancha de almunínio) que nos levaria à cidade, algumas mulheres interpelaram Jua para que fossemos registrar algo que aconteceria.

Quando chegamos ao hetô nos deparamos com um número grande de mulheres que andavam de um lado para o outro na casa e em torno de uma outra mulher com um bebê. Repentinamente (como que a um sinal que não pude perceber bem de onde partia) todas alvoroçaram-se em torno de uma bacia cheia de sabonetes (bastante vermelhos por conta do urucum), tentando pegar algum em meio a um mar de mãos e braços. Aquelas que conseguiam, saíam da casa a rir. Até que, em pouquíssimo tempo, restaram apenas a bacia vazia, a tia-avó, a avó e as netas sentadas no chão da sala. De acordo com Jua, os sabonetes foram oferecidos às brotyré170 da criança.

\footnotetext{
170 O brotyré (pronuncia-se brotãré) é um papel de enorme importância na cultura iny. De acordo com Toral (1992), os brotyré são como "um aliado para a criança em situações liminares que podem ameaçá-la" (p. 139). Diversos parentes (mais velhos ou mais novos que os pais) podem apresentar-se como brotyré da criança e recebem por isso retribuições materiais dos pais. No caso que acompanhamos, os pais do bebê ofereciam aos parentes mais próximos (provavelmente e, de acordo com Jua, os brotyré daquela criança) os sabonetes utilizados para limpar a pintura de urucum feita por uma tia-avó do bebê. Segundo Jua, essa pintura normalmente é feita na criança em seus primeiros meses de vida, no entanto, em algumas ocasiões, a mesma pode ser feita em um parente no lugar da criança (dependendo da vontade dos pais).
} 


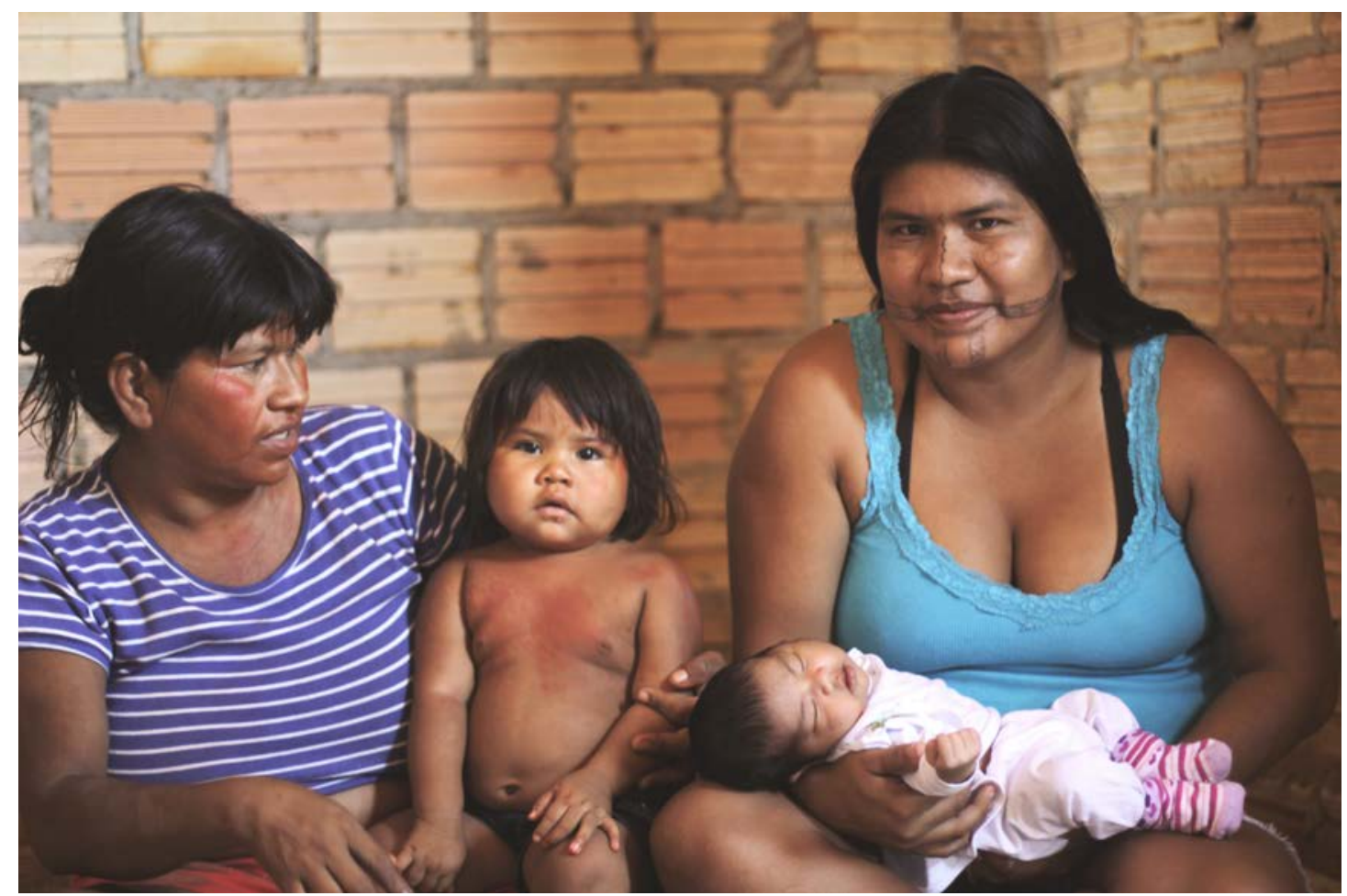

fig. 28 - Da esquerda para direita Myralu Derahawi (tia-avó), as crianças e Koixaru (avó do bebê), na casa onde se dera a oferta (no caso sabonetes) aos brotyré. (Foto: Caio Lazaneo)

Quando chegamos à cidade, acompanhamos Jua que decidira pedir formalmente o apoio da Funai para a exibição de seu filme na aldeia Fontoura e, ao mesmo tempo, gravar uma entrevista com Kohalue tanto sobre a festa de Ijasó quanto sobre a questão do suicídio. De forma mítica, Kohalue nos contou brevemente uma história (dizendo que assim desejava introduzir a conversa):

Assim que chegaram os primeiros europeus no Brasil, os mesmos se depararam com os indígenas, as praias lindas e assim por diante. Um primeiro português, por sua vez, teria tido um filho com uma índia e este (assim como sua mãe) fora rejeitado por sua etnia (passando a habitar entre dois mundos: entre os arredores dos aldeamentos indígenas e portugueses, sem ter efetivamente um lar). Passou assim a constituir um sujeito "sem-identidade", sendo filho de europeu não era índio e sendo filho de índio não era europeu. Kohalue abordava assim, sucintamente, a mestiçagem fundacional do país. Porém o fazia com um viés bastante crítico, dizendo que os jovens iny, hoje em dia, estariam em semelhante situação ao do primeiro filho mestiço do Brasil, portanto "sem identidade". 
Não obstante, embora sua fala pudesse embasar um certo imaginário de pureza (a qual não passaria de uma quimera, dado que mesmo antes da chegada dos portugueses, o contato interétnico sempre produzira mestiçagens), logo após a introdução, Kohalue assumia seu passado de jovem "farrista", de quem gostava de ir às festas (de "toris") na cidade sem, embora, nunca deixar de participar das festas de Ijasó, dos rituais Hetohoky, das pinturas corporais, etc, na aldeia. Seria, assim, um sujeito multi-identificado (multivíduo), em trânsito. Sendo "farrista" nas festas da cidade era iny, sendo iny na aldeia era também alguém que conseguia estabelecer algum trânsito com a cidade.

Não à toa, a meu ver graças a essa capacidade de circulação, tornara-se uma liderança (hoje chefe de posto da Funai em São Félix, um cargo bastante respeitado pelos demais iny). Tanto Jua quanto Kohalue (um tanto saudosistas) lamentavam: “Antigamente Hetohoky era 'forte'”. Jua, por sua vez, levantou a hipótese de que os inys mestiços seriam os maiores responsáveis (de modo geral) por levar as bebidas alcoólicas para as aldeias, uma vez que "inys puros" não poderiam comprar facilmente bebidas.

Jua aproveitou também para cobrar Kohalue quanto a um certo abandono da Funai em relação ao povo iny, ao que o chefe respondeu que por conta da mudança de portarias (e com as quais não compactuava) havia menos recursos e funcionários à disposição da Funai em São Félix (embora se tratando da questão indígena em âmbito institucional no Brasil, a falta de recursos e funcionários seja um velho enredo).

A propósito dos suicídios, Kohalue nos trazia com mais detalhes questões que até então apenas muito timidamente tínhamos escutado. Embora não fosse determinista quanto ao feitiço como sendo o motivo maior da onda de suicídios (elencando os problemas paralelos como o uso de álcool e drogas), tratava-o como uma questão "cultural espiritual". Segundo nos narrava, até seus 18 anos de idade (o período que viveu propriamente na aldeia Hawalo) este fato praticamente inexistia. Seu relato dava conta de que a onda teria iniciado em 2011 e vitimado muitos jovens, sempre com enforcamento. À época, fez parte de um grupo de trabalho (envolvendo instituições governamentais, agentes de saúde, lideranças indígenas, pesquisadores, entre outros) para investigar a causa 
dos recorrentes suicídios cuja conclusão fora de que as motivações seriam sobretudo três: Drogas, bebidas alcoólicas e feitiçaria.

E, segundo ele, no que tange ao assunto da feitiçaria, isso estaria somente ao alcance dos pajés e àqueles que não dominavam os segredos não restaria nada a fazer. Kohalue nos disse também que, tradicionalmente, os hyris seriam aqueles que foram pegos pelo espírito do aruanã, enquanto, de outro modo, havia também jovens que aprendiam feitiçarias (e que eram conhecidos como "feiticeiros") dedicando-se a praticar malefícios.

Os jovens que cometeram suicídio seriam, de acordo com Kohalue, substancialmente atingidos pelo "feitiço" por estarem fragilizados (com o "espírito fraco") por conta das drogas e bebidas alcoólicas. Dois anos antes, a Sesai - Secretaria Especial de Saúde Indígena, (a pedido da comunidade iny) havia contratado duas pajés xinguanas (que até onde conseguimos verificar seriam elas da etnia kamayurá) para fazerem uma espécie de varredura nas aldeias em busca de feitiços. Segundo Kohalue, à época teriam encontrado bonecos de cêra com fios de nylon enroladas no pescoço em determinados lugares das aldeias que passaram.

Os casos de suicídio então cessaram, mas paulatinamente teriam voltado a acontecer (cerca de 6 meses depois). Kohalue também narrou que à época do falecido Maluaré - um conhecido hyri da aldeia Hawalo -, os feitiços eram sempre "quebrados", já que os "conselhos" - reunião de hyris - teriam o controle espiritual sobre os feitiços, e ele próprio, era um hyri muito poderoso (algo raro hoje em dia), portanto alguém capacitado para desfazer feitiços, mesmo aqueles mais difíceis.

Cronologicamente o atual feitiço teria sido originado na aldeia Itxalá, depois "repassado" para a aldeia Macaúba, posteriormente para a aldeia Fontoura e, por fim, para a aldeia Hawalo. Às nossa dúvidas, Kohalue respondia: "Sokró sabe tudo. Ele, se quiser, conta tudo para você. Ele é pajé, ele vê o que está acontecendo lá, mas ele não vai te falar porque isso é segredo deles".

Ao fim da conversa nos encontrávamos inevitavelmente tanto surpresos quanto preocupados. De acordo com o diagnóstico de Kohalue, havia em curso um feitiço alastrado e sem controle. 
No meio da tarde um forte temporal caiu e veio ao nosso encontro quando de voadeira atravessávamos o Araguaia na volta à Hawalo. Chegamos ao hetô completamente ensopados, mas com os equipamentos a salvo graças às sacolinhas plásticas preventivamente trazidas por Juanahú, que tão bem conhece o clima local.

Pela tarde na escola de Hawalo, ainda pudemos entrevistar Chang Whan. Chang é curadora e gestora científica de documentação cultural do Museu do Índio (do Rio de Janeiro) e faz um importante trabalho junto ao povo iny, tendo organizado exposições sobre a sua cultura e, inclusive, propiciado que muitos deles participassem efetivamente das exposições (com demonstrações de cantos, rituais, artesanato, etc.).

Juanahú também participara de treinamentos no Rio de Janeiro junto à equipe de audiovisual do museu graças à mediação de Chang. Além do valioso trabalho de pesquisa sobre a bonecas artesanais iny (em inyrybé [língua karajá]: Ritxoco), Chang constantemente auxilia e participa das equipes de pesquisadores na área de linguística que se dedicam ao estudo da língua iny. Como pudemos observar, ela e sua família são muito bem recebidas pela comunidade onde há visivelmente um afeto recíproco.

Chang classifica como a luta pelos jovens como sendo a mais importante do povo iny. Este período de vida, em especial, que segundo ela situa-se em uma espécie de "limbo" (que poderíamos, nos termos de Turner, entender como liminaridade): Recém saídos da adolescência, não são ainda propriamente adultos, no entanto recebem uma enorme expectativa por parte da comunidade. Ao mesmo tempo são aqueles mais diretamente seduzidos pela cultura consumista da sociedade não indígena, posto que, em fase de afirmação, buscam identificar na cultura tori o que pode diferencia-los dentro da aldeia (uma moto, um celular, camisetas, etc.). E quando estão fora da aldeia, em contato com a "sociedade nacional", sobretudo nas grandes cidades do sul e sudeste, muitas vezes são valorizados no sentido do reconhecimento de uma cultura autêntica. Enquanto nas cidades próximas das aldeias (nas populações regionais) vivenciam de maneira mais intensa os preconceitos que secularmente destina-se aos indígenas no Brasil, tantas vezes tidos por "preguiçosos", "beberrões", 
"inaptos" ao trabalho, etc., gerando, deste modo, uma recusa à própria identidade étnica como forma de fugir destes estigmas.

Chang, assim, partilha de uma importante preocupação quanto a projetos que incluam atividades voltadas aos jovens iny, e isto está pensado e proposto diretamente em seu trabalho voltado para a valorização da língua e da cultura de forma geral. A propósito da questão do suicídio, Chang diz acreditar que, de algum modo, a maior incidência de suicídios entre os jovens poderia refletir certas contrariedades e comportamentos típicos de jovens fugindo de situações tensionantes e de pressão. 0 aspecto contagioso na sucessão dos suicídios, segundo sua leitura, refletia uma certa necessidade de "gerar comoção".

Um caso acontecia em uma aldeia e, repentinamente, se repetia em outras aldeias. Citou inclusive o caso de uma mulher iny que depois de brigar com o marido havia se jogado do alto da torre de telefonia da aldeia, um mês depois outro iny também teria cometido o suicídio de igual forma.

Pela noite Jua recebeu em seu hetô a visita de Eduardo Nunes. Eduardo que é antropólogo pela UNB, é também conhecido entre os iny de Hawalo como "Ioló". Ioló fala bem o inyrybé (língua iny), que é como habitualmente se comunica com os próprios iny no trabalho de campo em Hawalo. Está hoje no doutorado na UNB e desenvolve pesquisas junto aos iny desde sua graduação. Eduardo nos contou um pouco sobre sua pesquisa entre o iny de Buridina, onde fez sua pesquisa mestrado. E, como não poderia deixar de ser, conversamos bastante sobre a questão do suicídio. Ele, que participara a convite da Sesai do grupo de trabalho que elaborou um relatório sobre o suicídio entre os iny, era bastante convicto da hipótese do feitiço, acrescentando ainda mais detalhes ao que Kohalue havia nos contado pela manhã. Assim sugerimos gravar com ele uma entrevista no dia seguinte.

\section{Aldeia Fontoura}

Finalmente, com o apoio da Funai, seguimos até a aldeia Fontoura para, na parte da noite, exibirmos "Berahatxi-rbi Olodu Mahadu" no local em que ele fora gravado. Antes de partirmos gravamos uma entrevista com a psicóloga 
Elisabete Alves Gama, funcionária da Sesai e amiga de Jua. Ela fora contratada pelo orgão para acompanhar desde os casos de tentativa de suicídio entre os iny, bem como realizar assistência às famílias que perderam seus parentes. Desde nossa chegada a São Félix, vínhamos tentando obter oficialmente (através da Sesai) os números exatos de casos que o órgão considerava em seus relatórios, entretanto mesmo com bastante insistência não nos foram liberadas maiores informações.

Agora, durante a entrevista, Elisabete nos trazia os dados com que a Sesai trabalhava e que seriam, segundo ela, 4 casos em 2002, 2 casos em 2005, 2 casos em 2008, 8 casos em 2012, 2 casos em 2013 e 6 casos em 2014, totalizando 24 casos. Segundo ela, uma das características mais visíveis em suas visitas às aldeias é uma espécie de "desmantelamento" de uma estrutura tradicional que consistia em reuniões ao fim do dia onde os mais velhos narravam histórias aos mais jovens, algo que hoje é muito raro de ocorrer. Uma segunda característica, de ordem econômica, consiste no fascínio que os jovens iny nutrem pelos objetos materiais (pouco acessíveis) da sociedade não indígena. Por fim, Elisabete considerava ainda essencial a hipótese do feitiço como algo que exerce grande influência do ponto de vista sócio-cultural entre os iny.

Ao término da entrevista, uma caminhonete nos levou até a aldeia Teribré onde, depois de esperarmos uma forte chuva passar, atravessamos a barco o Araguaia para chegar a Btoiry (Aldeia Fontouta). Para nossa tristeza, ao chegar Btoiry fomos informados de que a aldeia estava sem energia e o prazo para o religamento não era nada animador. Assim, a projeção, do filme que dependia da energia, não poderia ocorrer.

De qualquer forma percorremos a aldeia com Jua que fez questão de levar um dvd para a família de um jovem já falecido, que aparecia no filme. Passamos a noite em uma casa de alvenaria que serve de abrigo aos funcionários da Funai e Funasa quando estão na aldeia. Como a proximidade com o rio era enorme, a quantidade de "muriçocas" também o era. Assim passamos a noite brigando contra os mosquitos que fizeram de nós o seu inesgotável banquete. Logo pela manhã do dia seguinte fizemos o caminho de volta e aproveitamos o período da tarde para gravarmos, já em Hawalo, uma entrevista com Juanahú sobre sua percepção em torno do suicídio. 


\section{De volta a Hawalo, chegaram os aruanãs.}

Depois de uma noite extremamente mal dormida, por conta do excesso de picadas, o dia tornou-se substancialmente exaustivo. As incômodas picadas tiravam-nos o humor. Cheguei a contar três delas na região da testa, um lugar que eu sempre julgara inoportuno para insetos ávidos por sangue. Pela tarde por fim gravamos uma entrevista de Jua com uma velha artesã que em sua fala explanava a tristeza de ver a aldeia de hoje, mesmo em tempos de festa Ijasó, tão pouco festiva, desconfiando até mesmo de que não veria a chegada dos aruanãs.

Pela manhã, com a urgência da partida, conseguimos ainda gravar uma nova e rápida entrevista com o cacique Iwuraru, da aldeia Ataú, que estava em Hawalo. Nos preparativos deste Hetohoky, em especial, Iwuraru se encontrava demasiadamente ocupado já que um dos jyrés (jovem iniciante) é seu neto e, portanto, isso lhe demandava enorme dedicação. Surpreendentemente Iwraru tem um ponto de vista bastante divergente em relação aos suicídios, chegando a classificar que a ideia de que seriam motivados por feitiço não passaria de "crendice". Em sua família mesmo já havia presenciado duas tentativas mais próximas, sendo uma de sua esposa e uma do filho. No caso da esposa, a tentativa sucedera a uma briga conjugal e de mesmo modo no caso do filho. Ambos os casos o levavam a crer em uma certa "fraqueza do pensamento" que abatia as pessoas que tentavam o suicídio.

Pela tarde finalmente pudemos acompanhar a tão esperada chegada dos Aruanã pelo rio. 0 momento que antecedia a chegada gerava um grande burburinho na aldeia. Na margem, um grupos de homens, de modo altivo, mirava o rio ao mesmo tempo em que ininterruptamente conversavam. Para nós era bastante nítido que a chegada do Aruanã tinha seu impacto imediato nos ânimos da comunidade, que parecia se mostrar, em especial naquela ocasião, mais festiva e coesa. Os aruanãs por fim desembarcaram na aldeia e, mais ou menos em torno de uma hora, entoaram seus cantos e danças específicas com grande parte da população local seguindo-os por seu percurso. Aproveitei o belo final de tarde para gravar às margens do rio uma imagem que a alguns dias vinha, em termos de composição, nos chamando a atenção. Em uma de nossas andanças 
pela aldeia havíamos encontrado uma boneca de cerâmica (ritxoco), perdida em uma estrada, representando uma mãe que carregava uma criança. Em algum momento da confecção da peça, algo se sucedera e a criança no colo da mãe perdera a cabeça. Por isso, nos parecia evidente, a peça havia sido despretensiosamente dispensada, já que provavelmente não teria mais valor comercial.

Quando a encontramos, de imediato vimos naquela peça uma metonímia da atual situação dos iny: Uma mãe que carrega um filho em seus braços mas, no entanto, o filho já não mais está lá. Assim, aquela imagem nos comunicava algo e de algum modo propunha uma reflexão para os filmes que vínhamos realizando. Pela noite, por fim, gravamos uma nova roda de conversas de Juanahú com seus filhos. Ao final, recebemos dos filhos de Jua carinhosos desenhos (em que eles nos retratavam) e assim nos despedimos para o início do retorno logo na manhã do dia seguinte.

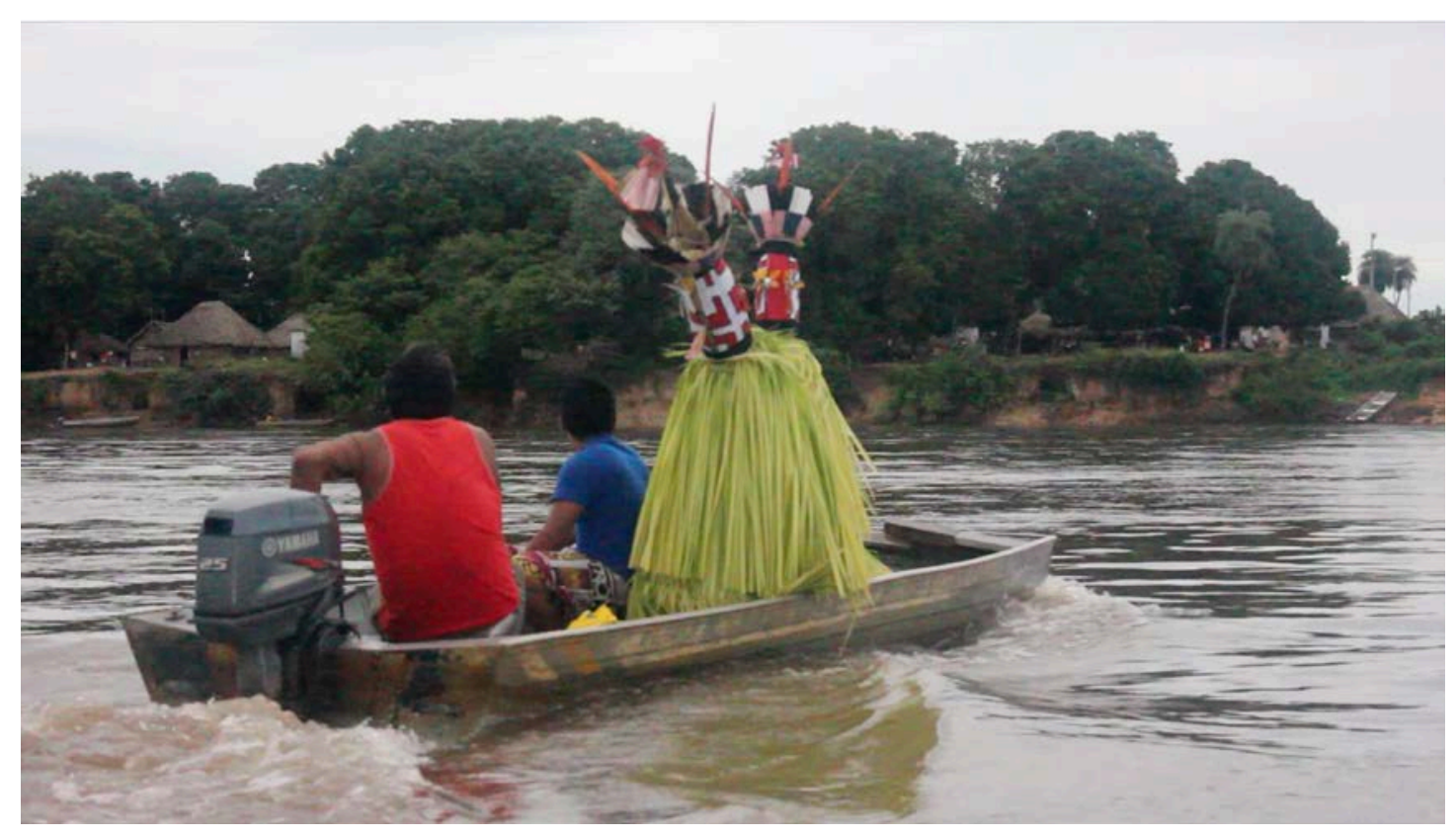

fig. 29 - Chegada dos Aruanãs à Hawalo (Foto Caio Lazaneo) 


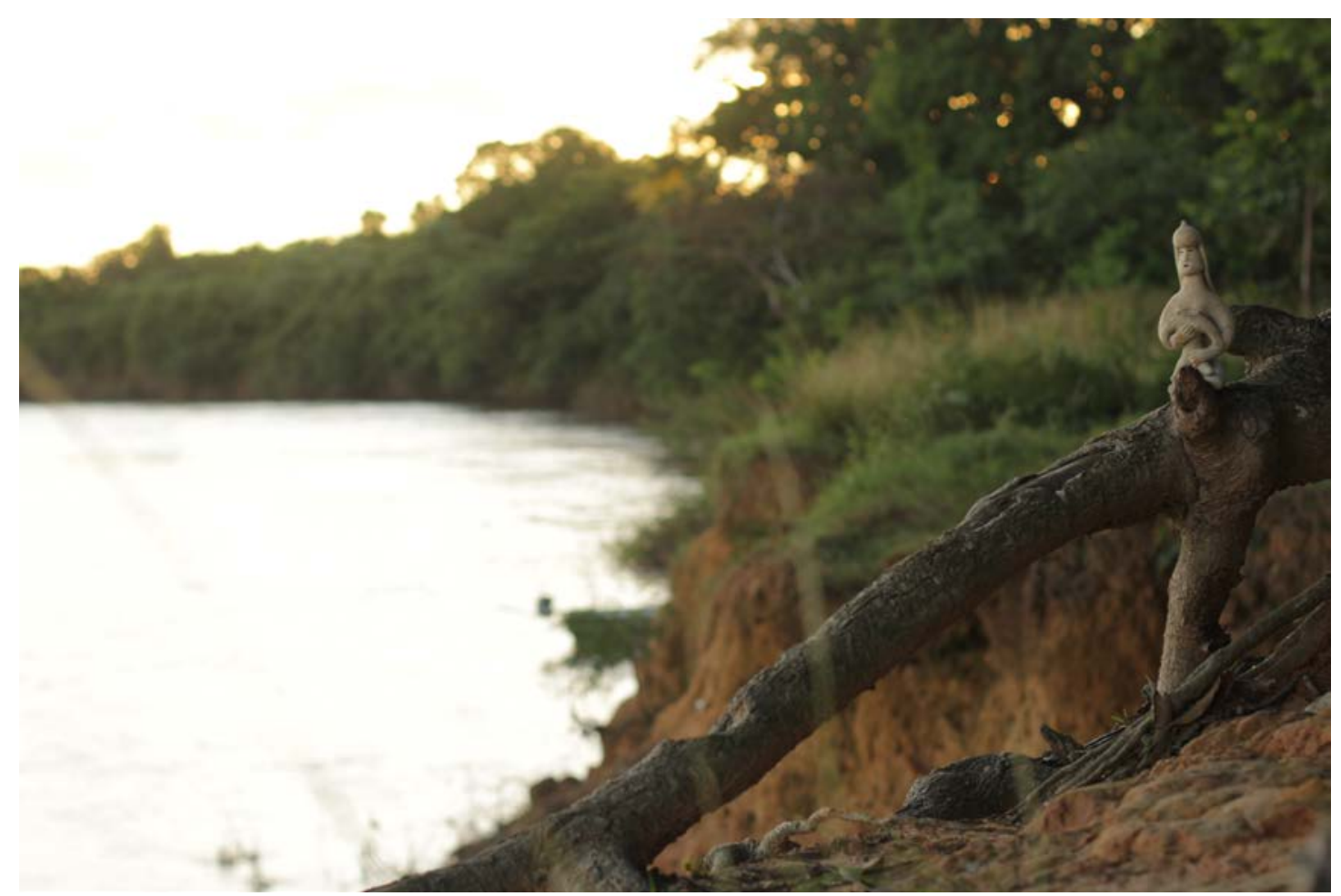

fig. 29 - Ritxoco na beira do rio Araguaia. (Foto: Caio Lazaneo) 
Não poder se orientar numa cidade não significava muita coisa; mas para se perder, como a gente se perde na floresta, para isso é preciso aprendizado. (BENJAMIN apud MARCONDES FILHO, 2007) ${ }^{171}$

Nos caminhos desta pesquisa buscamos propor composições poéticas enquanto ima(r)gens, desenhos livres, com os quais saboreamos um pouco de um saber primitivo, sensível, como expresso por Vico, em que "o labor mais sublime da poesia está em dar sentido e paixão às coisas insensíveis e é uma característica das crianças o tomar em coisas inanimadas entre as mãos e, brincando, falar-lhes como se elas fossem pessoas vivas." 172 (VICO, apud BAIRON, 2014). Outrossim, dentro da marginalidade do texto científico acadêmico, propomos uma compreensão da Reticularidade Fílmica, enquanto uma possibilidade (re)inaugural da inter-relação entre a oralidade, a aleatoriedade, a experiência estética, o audiovisual, a ambiência hipermidiática e a Produção Partilhada do Conhecimento. Assim sublinhamos a proximidade conceitual que, no sentido fílmico, abrangem as proposições anteriores às novas medias e as taxionomias e compreensões apropriadas ao audiovisual interativo. Assim, no sentido poético, buscamos também propor reflexões e sensibilidades subsidiadas por estas relações, ou melhor, por "extras" relações.

Os filmes em reticularidade analisados, apontam-nos um caminho auspicioso nesta direção. "Out my "Window" expressa o perder-se em meio ao mundo das habitações verticais, reencontrando os sentidos em uma experiência do acolhimento, na casa dos sujeitos que são os próprios narradores de suas histórias, como se fossemos convidados a adentrar suas habitações. Sua ambiência, sua interatividade, sua autonomia da interface, sua polifonia na

171 MARCONDES FILHO, C. J. R. Walter Benjamin e a difícil conciliação entre encantamento com a técnica e desespero com a história. Um pensador fora dos moldes. In Revista (UNAERP), v. 3, p. 2-20, 2007.

172 In VICO, Gianbatista. Ciência Nova. Lisboa, Cotovia, 1990. p. 67. 
concepção imagética e sonora, sua estrutura reticular, demonstram uma solução ímpar que, por outro lado, enfatiza também a complexidade de sua produção.

Nos percursos que nos tangenciam, embora compreendamos esta enquanto uma reticularidade fílmica exemplar, guardamos ainda, evidentemente, uma distância desta capacidade operacional, em que proposições desta natureza, por vezes, chegam a envolver equipes de 30 ou mais profissionais, entre programadores, realizadores, produtores, etc.

Por outro lado, "Rodovia Rojoko" e as reticularidade guarani-mbya, demonstram de forma relativamente simples a apropriação necessária de uma "ocupação digital-reticular" que é, sobretudo, empreendida a partir do audiovisual. Aquilo que chamamos de "media xonadro", compreende no contexto pós-colonialista, um contra-ataque mediático a partir de características específicas destes povos. As manifestações reticulares organizadas pelos guarani-mbya e sua Comissão Guarani Yvyrupá, sobretudo desde 2012, traduzem a dimensão premente da ação de populações sujeitas a todo tipo de violência produzidas pelo processo colonial e que, não obstante, têm nestas lutas logrado importantes conquistas político-jurídicas, como a demarcação de seus territórios na cidade de São Paulo.

Os interlocutores dos povos karajá, xavante e bororo, com os quais nos relacionamos nas proposições de Produção Partilhada, demonstram também a apropriação desta espécie de "media xondaro", produzindo audiovisuais com ênfase em suas questões cotidianas, inerentes aos seus modos de vida e às diversas problemáticas que vivenciam. Outrossim, a Produção Partilhada enseja a oportunidade do diálogo entre novas redes, espirais reticulares, nas quais estes povos possam mutuamente articular demandas, contrapor e evidenciar violências institucionais e produzir conhecimento. Assim como enfatiza Bairon,

[...] o que faz sentido na contemporaneidade é que o saber acadêmico aprenda e divida espaços de aprendizagem com o senso comum cultural com o qual interage. Uma espécie de filosofia às avessas, por meio da qual não intencionamos apenas nossos pares da academia, mas possamos criar condições de respeito e convivência intelectual com um tipo de intelectualidade orgânica que raramente foi considerada como tal." (2014, p. 66) 
Não podemos, entretanto, deixar de observar e refletir sobre as próximas coordenadas do atual processo principiado com os trabalhos na aldeia Hawalo. Como problematizado na introdução desta tese, a criação do banco de dados fílmicos que comporá esta primeira experiência de Reticularidade Fílmica em Produção Partilhada com os karajá, encontra-se ainda em processo, isto é, não em processo em seu sentido fruitivo, senão ainda na estrutura de uma préprodução. Como salientado, demandamos portanto o apuro linguístico da tradução, bem como de uma logística que propicie frequentemente encontros entre os pesquisadores.

Esta questão enseja ainda refletir sobre a dimensão tecnológica que, na atual conjuntura, pode atuar de certa forma em direção contrária a uma desejável democratização destes trabalhos. Quando nos deparamos com as limitações no acesso à internet, sobretudo das populações geograficamente afastadas dos grandes centros urbanos, faz-se necessário antever um problema inerente à criação das estruturas fílmico-reticulares. Se os filmes em plataformas de compartilhamento, muitas vezes são suficientemente pesados ao ponto de impedir àqueles que não dispõem de conexão e banda, que os assistam, as ambiências reticulares são, nestes contextos, ainda mais inacessíveis, pois pressupõem o "carregamento" dos diversos vídeos, que a compõem, para permitir sua navegação. Isto nos direciona a uma complexa relação econômica e tecnológica que deve ser suficientemente enfrentada. Neste sentido, os pesquisadores da Produção Partilhada devem pensar estratégias possíveis para o que o processo de devolução dos filmes se dê de uma forma coerente à proposta, mesmo que isto signifique recorrer temporariamente à medias com menores possibilidades interativas.

Em relação ao trabalho em curso junto à Hawalo e Juanahú, os filmes reticulares proporão construir principalmente uma reflexão a propósito dos dois problemas mais urgentemente enfrentados por esta comunidade: $\mathrm{O}$ abandono da festa de Aruanã e o suicídio entre os jovens. Curiosamente, em um breve intervalo enquanto escrevo estas linhas, recebo um telefonema de Juanahú que me expõe que as competições de futebol estão "crescendo cada vez mais". Além do futebol, ele conta-me que a igreja Adventista tem formado grupos de jovens 
(evangelizadores) entre os iny, nomeados "desbravadores". Temas sobre os quais, Juanahú, a seu modo, expõe recorrentemente sua vontade de produzir reflexões.

Assim, seguimos com uma "produção nos fios da ação partilhada griô". Neste fios e nós, a Antropologia Partilhada encontra-se também, pois, com um pilar fundamental da Pedagogia Griô, qual seja a perspectiva do encantamento, isto é, da valorização do encontro, como o olhar desarmado (nos termos de Vertov), que possa "reconhecer o lugar social e político da pessoa de tradição oral como sujeito, autor, educador" (PACHECO, 2016, p. 42). A Antropologia Partilhada de Rouch é sempre produto de um encontro, não subsidiado em princípios teóricos predeterminantes, portanto

não é uma 'antropologia aplicada' que se tem em vista, afinal, isso implicaria do mesmo modo a anterioridade da teoria em relação à prática, pois somente se aplica a um conhecimento que já foi construído de antemão. Para Rouch, prática e teoria, assim como etnografia e cinema, se dão concomitantemente". (SZTUTMAN, 2004, p. 53)

$\mathrm{Na}$ mesma medida os pilares metodológicos da pesquisa-ação correspondem às premissas éticas em campo tanto da Pedagogia Griô quanto da Antropologia Partilhada. Nestes laços, a comunicação, e poderíamos portanto dizer o conhecimento, somente faz sentido enquanto ação partilhada e, para além, espiralada.

Ao perpassarmos as relações mais próximas da Produção Partilhada com a Antropologia Partilhada, a Pedagogia Griô e a Pesquisa-ação, propomos portanto uma composição a partir dos "fios", embora intangíveis, de ação partilhada griô. Isto é, criar articulações, proposições, conjunções, "desenhos livres", que envolvam trabalhos com comunidades, e que nestes trabalhos os grupos organizem-se com vistas à possibilidade da melhoria em questões que lhes aflijam, que os saberes locais passem por uma ampla valorização, que a oralidade subsidie encontros e partilhas, que os produtos sejam desenvolvidos heterarquicamente na construção conjunta de horizontalidades de sentidos, que 
a experiência estética que subsidia modos de vida não seja solapada (e que esteja devidamente tratada em filmes, ambiências hipermidiáticas, rodas, encontros, no batuque, no canto, na dança, no corpo e, inclusive, nos livros), que o feedback esteja circunscrito às etapas de pesquisa, que haja acolhimento do pesquisador na comunidade (desde que essa assim deseje) e que haja acolhimento de interlocutores da comunidade na universidade e que o pesquisador, portanto, crie espaços e laços para tanto.

Como enfatizamos ao longo desta tese, procuramos endossar a perspectiva do reconhecimento que deve existir no papel epistemológico, cognitivo e dialógico da produção de imagens e sons, isto é, o que Bairon, chama de "os desdobramentos sinestésicos de uma corporeidade da escritura" (2014, p. 63). No lugar do caráter de ilustração que o meio científico habitualmente relegou a estas instâncias é, portanto, no "modo oral de ser do senso comum cultural" que encontramos uma perspectiva outra, fecunda, em que estas experiências estéticas e expressividades configuram, desde sempre, parâmetros fundamentais na transmissão e na produção do conhecimento dentro do senso comum cultural.

A partir de uma abordagem no liame entre a estética e política, Rancière (1995, p.7) assim compreende que

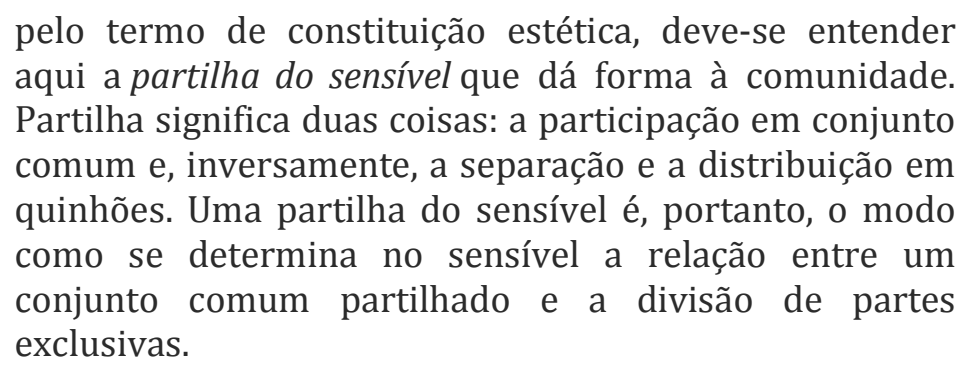

Compreendemos que, portanto, consiste na experiência estética o lugar inaugural que possibilita um encontro comum, partilhado, entre universidade e comunidade (dois polos de instâncias políticas, bem como, poderíamos entender, de produções estéticas). Assim, este encontro não poderia, de outro modo, somente materializar-se no livro, na tradição de uma matriz que erigiu-se e consolidou-se no distanciamento dos saberes, da autoria individual. Para Rancière, “[...] a política ocupa-se do que se vê e do que se pode dizer sobre o que 
é visto, de quem tem competência para ver e qualidade para dizer, das propriedades do espaço e dos possíveis do tempo". (2005, pp. 16-17). Assim, o sensível partilhado é como um híbrido onde as partes comuns (o conjunto comum partilhado) atuam em uma composição que redefine amiúde os lugares e portanto as políticas - do mundo. Outrossim, a Produção Partilhada e a Reticularidade Fílmica, a partir daquilo que Bairon (2007) compreende como a "retomada da experiência estética na produção do conhecimento", podem atuar conjuntamente nesta composição onde o audiovisual digital-reticular é um locus fundamental para seu subsídio. 


\section{REFERÊNCIAS}

AARSETH, Espen J. Nonlinearity and Literary Theory. In: Landow, George ed. Hyper/Text/Theory. Baltimore: John Hopkins University Press. 1994. pp. 51-86.

ARAÚJO, Ana Carvalho Ziller; CARVALHO, Ernesto Ignacio de \& CARELLI, Vincent (orgs.). Vídeo nas Aldeias 25 anos: 1986-2011. Olinda: Vídeo nas Aldeias, 2011

BAIRON, Sergio. A formação interdisciplinar e não-disciplinar na produção de conhecimento: ou o que ainda temos a aprender : a habilitação do senso comum nas esferas heterárquicas da produção de conhecimento. Anais do IX Seminário Internacional Imagens da Cultura / Cultura das Imagens São Paulo: [s.n.], 2014. Disponível em:

http://www2.eca.usp.br/redeicci/ebook/ebook_ICCI_2013.pdf Acesso em: $04 / 08 / 2016$

BAIRON, Sérgio. A hipermídia como comunicação integrada e a retomada da experiência estética na produção de conhecimento. Tese de livre docência. Universidade de São Paulo, 2007.

BAIRON, Sérgio. Os movimentos da estética: o cinema de Dziga Vertov como reflexão à Hipermídia. RUA. Revista Universitária do Audiovisual - UFSCar, v. 07, p. 3-12, 2008.

BAIRON, Sérgio. Tendências da Linguagem Científica Contemporânea em Expressividade Digital. Cibertextualidades:Portugal - Porto, v. 1, n. 1, p. 53-106, 2006.

BAIRON, Sérgio, LAZANEO, Caio. Produção Partilhada do conhecimento: Do filme à hipermídia. In: COSTA, Maria Cristina (org). Comunicação, Mídias e Liberdade de Expressão. 1. ed. São Paulo: Intercom, 2013, v.04, pp. 57-79.

BAIRON, Sérgio, PETRY, Luís Carlos. Hipermídia, Psicanálise e História da Cultura. São Paulo / Caxias do Sul, Educs / Ed. Mackenzie, 2000.

BAIRON, Sérgio; LAZANEO, Caio. S. BATISTELLA, Roberta. Fundamentos da Produção Partilhada do Conhecimento e o saber do Mestre Griô. Revista Diversitas, v. 3, p. 246-265, 2015.

BARCINSKI, Philippe. 0 Cinema ainda está na Pré-História, in: Revista Bravo, ano 11, no 122. São Paulo: Abril, out. 2007, Pp, 78-80.

BARTHES, Roland. Elementos da semiologia. São Paulo: Cultrix, 2006. 
BARROS, Edna Pina; BORDIGNON, Mario. Jarudori: Terra Indígena invadida. $2009 . \quad$ Disponível em: http://static.recantodasletras.com.br/arquivos/2613032.pdf?1289730528 Acesso em 10/10/2016.

BAZIN, André. 0 que é o cinema? São Paulo;Cosac Naify,2014.

BENSE, Max. Inteligência brasileira: uma reflexão cartesiana. São Paulo: Cosac Naify;2009.

BULGAKOWA, Oksana. Eiseinstein, the Glass House and the Spherical Book. 2005. Disponível em: http://www.rouge.com.au/7/eisenstein.html. Acesso em 20/03/2015.

BRAND, Stewart. The Media Lab. London: Penguin. 1998.

CAIXETA, Rubens, GUIMARÃES, César. Pela distinção entre documentário e ficção, provisoriamente. In: COMOLLI, Jean-Louis. Ver e poder A inocência perdida: Cinema, Televisão, Ficção, Documentário. Belo Horizonte: Editora UFMG. 2008.

CALABRESE, Omar. A idade neobarroca. Lisboa: Edições 70, 1987.

CANCLINI, Néstor García. As culturas populares no capitalismo. São Paulo: Brasiliense, 1983.

CANCLINI, Néstor García. Culturas híbridas: estratégias para entrar e sair da modernidade. São Paulo: Edusp, 2013.

CANEVACCI, Massimo. Digital Auratic Reproducibility: Ubiquitous Ethnographies and CommunicationalMetropolis, An Ethnography of Global Landscapes and Corridors, Diponível em: http://www.intechopen.com/books/an-ethnography-of-global-landscapesandcorridors/digital-auratic-reproducibility . 2012. Acesso em 03/03/2016.

CARELLI, Vincent, GALLOIS, Dominique. Vídeo e Diálogo Cultural Experiência do projeto Vídeo nas Aldeias. Horizontes Antropológicos, Porto Alegre, ano 1, n. 2, p. 61-72, jul./set. 1995

CASTRO, Eudardo Viveiros de. 0 nativo relativo. Revista Mana. Número 8. páginas: 113-148, 2002

CHIAMPI, Irlemar. Barroco e Modernidade: Ensaios sobre literatura latinoamericana, São Paulo: Perspectiva: FAPESP, 1998.

CLASTRES, Pierre. A sociedade contra o estado.

COELHO, Renato; ESTEVES, Leonardo. (Org.). Rosemberg 70 - Cinema de afeto. 1ed.: , 2015. 
COLLEYN, Jean-Paul,.Jean Rouch, presque un homme-siècle, L'Homme, pp. 171-172 - Musique et anthropologie, Disponível em: http://lhomme.revues.org/25007 Acesso em 13/10/2016.

COMOLLI, Jean-Louis. O Futuro do Homem. O homem da câmera de filmar. in: O Olhar de Ulisses. O Homem e a Câmara. Cinemateca Portuguesa. 2001. pp. 47-67.

COSTA, Ana Carolina da; LIMA, Mestre Alcides de. Dos griots aos Griôs: a importância da oralidade para as tradições de matrizes africanas e indígenas no Brasil. Revista Diversitas, v. 3, p. 216-245, 2015.

DANOWSKI, Débora, CASTRO, Eduardo Viveiros de. Há mundo por vir? Ensaios sobre os medos e os fins. Desterro (Florianópolis): Cultura e Barbárie: Instituto Socioambiental. 2014.

DA-RIN, Silvio. Espelho Partido: Tradição e transformação no documentário. Rio de Janeiro: Azougue Editorial, 2004

DELEUZE, Gilles. A imagem-tempo. Tradução Eloisa de Araujo Ribeiro. São Paulo: Brasiliense, 2005.

EISENSTEIN, Sergei. A forma do filme. São Paulo:Zahar. 2002.

EISENSTEIN, Sergei. O sentido do filme. São Paulo:Zahar,2002.

FARIA, Camila Salles de. A luta Guarani pela terra na metrópole paulistana: contradições entre a propriedade privada capitalista e a apropriação indígena. Tese (Doutorado) - Faculdade de Filosofia, Letras e Ciências Humanas da Universidade de São Paulo. Departamento de Geografia. São Paulo, 2015.

FERREIRA, Jairo. Cinema de Invenção. Azougue Editorial: 2016.

GADAMER, Han-Georg. A verdade e método I: Traços fundamentais de uma hermenêutica filosófica. Tradução de Flavio Paulo Meurer; Revisão de tradução de Enio Paulo Giachini. 11 ed - Petrópolis, RJ: Vozes, 2011

GALLOIS, Dominique Tilkin. Terras ocupadas? Territórios? Territorialidades? In: RICARDO, Fany (org.) Terras Indígenas e Unidades de Conservação da Natureza: o desafio das sobreposições. São Paulo: Instituto Socioambiental, 2004, p. 37-41.

GAUDENZI, Sandra. The Living Documentary: from representing reality to co-creating reality in digital interactive documentary. Tese de Doutorado. University of London. 2013.

GONÇALVES, Marco Antônio, 0 real imaginado. Etnografia, cinema e surrealismo em Jean Rouch. Rio de Janeiro, Topbooks/ Capes, 2008. 
GONÇALVES, Marco Antônio. Sensorial throught: Cinema, perspective and Anthropology. Vibrant. V9, n.2. p. 160-183. 2012.

HAMPATÉ BÂ. Amadou. A tradição viva. In: KI-ZERBO, J. (coord.) Metodologia e Pré-História da África, História Geral da África. Brasília: Unesco, 2010. v.1

HIKIJI, Rose Satiko G. Rouch compartilhado: Premonições e provocações para um antropologia contemporânea. Iluminuras, Porto Alegre, v.14, n.32, p.113-122, jan./jun. 2013

LAZANEO, Caio de Salvi. Produção partilhada do conhecimento: uma experiência com as comunidades indígenas Xavante e Karajá. 2012. Dissertação (Mestrado em Teoria e Pesquisa em Comunicação) - Escola de Comunicações e Artes, Universidade de São Paulo, São Paulo, 2012.

LATOUR, Bruno. Jamais Fomos Modernos: ensaios de antropologia simétrica. Rio de Janeiro: Ed. 34. 1994

LÉVY, Pierre. 0 que é o virtual? São Paulo: Editora 34, 1996.

LIPOVETSKY, Gilles \& SERROY, Jean. A Tela Global: mídias culturais e cinema na era hipermoderna. Ed. Sulina, Porto Alegre: 2009.

MANOVICH, Lev. Histories of Internet Art. Disponível em: http://art.colorado.edu/archive/hiaff/interviewc154.html?id=133\&cid=12, 2002, Acesso em 04/06/2016.

MANOVICH, Lev. The Language of New Media. MIT: 2001

MEAD, Margaret; BATESON, Gregory. "'For God's sake, Margaret', conversation with Gregory Bateson and Margaret Mead" (by Stewart Brand). The CoEvolution Quarterly, California, University of Pensylvania, 1976, June, no. 10 (published by the Whole Earth Catalog), pp. 32-44. 1976

METZ, Christian. A Significação no Cinema. Tradução de Jean-Claude Bernardet. São Paulo: Perspectiva, 1977

METZ, Christian. O significante imaginário. Psicanálise e Cinema. Lisboa: Livros Horizonte., 1980.

MILANEZ, Felipe. Martírio: um filme para indignar Brasília. Revista Carta Capital. Publicado em 22/09/2016. Disponível em: http://www.cartacapital.com.br/cultura/martirio-um-filme-para-indignarbrasilia . Acesso em: 05/10/2016

MONTEIRO, John Manuel de. Dos Campos de Piratininga ao Morro da Saudade: a presença indígena na história de São Paulo. In: Porta, Paula. 
História da cidade de São Paulo: a cidade colonial. vol.1. São Paulo, Paz e Terra, 2004.

MOURÃO, Maria Dora G. Reflexões sobre o cinema e o movimento das novas tecnologias. Tese de livre docência. Universidade de São Paulo.1998.

NIANE, Djibril Tamsir. 0 Mali e a segunda expansão manden. In: NIANE, Djibril Tamsir (coord.). África do século XII ao XVI, História Geral da África. Brasília: Unesco, 2010. v.4

NICHOLS, Bill. Introdução ao documentário. Campinas;Papirus, 2012.

NICHOLS, Bill. Representing realities. Issues and concepts in Documentary. Bloomington: Indiana University Press. 1991

PACHECO, Lilian. Pedagogia Griô: A reinvenção da Roda da Vida. LençóisBahia, Grãos de Luz e Griô, 2006.

PACHECO, Lilian. A Pedagogia Griô: educação, tradição oral e política da diversidade. Revista Diversitas, São Paulo:USP. ano 2 n.3. set 2014/mar 2015. p. 22-99.

PEREIRA, Eliete da Silva. o local digital das culturas: as interações entre culturas, medias digitais e territórios. 2013. Tese (Doutorado em Interfaces Sociais da Comunicação) - Escola de Comunicações e Artes, Universidad de São Paulo, São Paulo, 2013.

PIAULT, Marc-Henri. Anthropologia y Cine. Traducción de Manuel Talens. Ediciones Cátedra: Madrid, 2002.

PINK, Sarah. The future of visual anthropology. New York, London, Routledge, 2006

PISSOLATO, Elizabeth. A duração da pessoa: mobilidade, parentesco e xamanismo mbya (guarani). São Paulo: Unesp Editora: Pronex: Nuti/ ISA, 2007.

RANCIÉRE, Jacques. A partilha do sensível. Editora 34. 2005.

RANCIÉRE, Jacques. A política da escrita. Editora 34. 1995

RIBEIRO, José da Silva. Jean Rouch: Filme etnográfico e Antropologia Visual. Doc On-line, n.03, Dezembro 2007, pp. 6-54. Disponível em: http://www.doc.ubi.pt/03/artigo_jose_ribeiro.pdf . Acesso em 23/10/2015.

RIBEIRO, José da Silva; BAIRON, Sérgio. (Org.). Antropologia Visual e Hipermídia. Lisboa: Edições Afrontamento, 2007, p.13- 41. 
RIBEIRO, José da Silva. Homem da Câmera de Filmar: o cinema ou uma história do cotidiano? Revista Galáxia, São Paulo, n. 11, p. 37-55, jun, 2006.

ROCHA, Marília Librandi. A Carta Guarani Kaiowá e o direito a uma literatura com terra e das gentes. Revista de Estudos de Literatura Brasileira Contemporânea. UNB, 2014.

ROCHA, Marília Librandi. Escritas de ouvido na literatura brasileira. Literatura e Sociedade, São Paulo, n. 19, p. 131-148, apr. 2015. Disponível em: http://www.revistas.usp.br/ls/article/view/97228. Acesso em: 20/05/2016

ROSA, Marilse. 0 ativismo político indígena no Brasil pós-1988 e os desafios à garantia dos seus direitos. 8ํㅡㄹ Encontro da ANDHEP - Políticas Públicas para a Segurança Pública e Direitos Humanos. Faculdade de Direito USP. São Paulo, 2014.

ROUCH, Jean. "Entrevista com Jean-Paul Colleyn". Cadernos de Antropologia e Imagem (1), Rio de Janeiro, UERJ, 1995.

ROUCH, Jean. The camera and Man. In: CINÉ-ETNOGRAPH/ Jean Rouch ; edited and translated by Steven Feld.. Visible evidence . v. 13. 2003.

RUBY, Jay. Los últimos 20 años de Antropología visual - una revisión crítica. Revista Chilena de Antropologia Visual. Número 9. Santiago: 2007.

SANTOS, Boaventura de Sousa. Introdução a uma ciência pós-moderna. Porto: Edições Afrontamento. 2002

SANTOS, Boaventura de Sousa (org.). Semear outras soluções: os caminhos da biodiversidade e dos conhecimentos rivais. Rio de Janeiro: Civilização Brasileira, 2005

SCHMIDLEHNER, M. F. Os desdobramentos do capitalismo de desastre no Acre: a "adicionalidade do medo". Revista Contra Corrente, Belém - PA, p. 29 32, 23 set. 2013.

SHOHAT, Ella e STAM, Robert. Crítica da imagem eurocêntrica: Multiculturalismo e Representação. São Paulo: Cosac Naify, 2006.

SZTUTMAN, Renato. 2004. Imagens perigosas: a possessão e a gênese do cinema de Jean Rouch. Cadernos de campo, n.13, 2005.

SZTUTMAN, Renato. 2004. Jean Rouch, um antropólogo-cineasta. In CAIUBY NOVAES, Sylvia et alli (orgs.) Escrituras da imagem. São Paulo: Edusp, pp. 49-62.

TEIXEIRA, Francisco Elinaldo. (Org.). Documentário no Brasil: tradição e transformação . São Paulo: Summus. 2004.

THIOLLENT, Michel. Metologia da pesquisa-ação. São Paulo: Cortez, 2011. 
TORAL, André Amaral de. Cosmologia e Sociedade Karajá. UFRJ. Dissertação de mestrado, 1992.

WITNESS, Global. En terreno peligroso. 2015.

XAVIER, Ismail (org.). A experiência do cinema. Rio de Janeiro: Graal, 1983.

XONDARO Mbaraete: a força do xondaro. Coordenação editorial: Centro de Trabalho Indigenista (CTI). São Paulo: 2013.

\section{FILMOGRAFIA:}

\section{Filmes disponíveis no youtube:}

A Universidade e a Pedagogia Griô - Matéria PGM:

https://www.youtube.com/watch?v=TCSiE_FH5Jo

Berahatxi-rbi Olodu Mahadu:

https://www.youtube.com/watch?v=E6_FEeu51bI\&t=454s

Curso Pedagogia Griô e Produção Partilhada na USP:

https://www.youtube.com/watch?v=_Z7hN4dGWGo

MANIFESTO por quê paramos a rodovia dos bandeirantes:

https://www.youtube.com/watch?v=eV7WMdvGirM

MENSAGEM à bancada ruralista:

https://www.youtube.com/watch?v=zFMKpzSU9Yk

RODOVIA Rojoko:

https://www.youtube.com/watch?v=JCBOU4wQmR8

\section{Filmes em outros suportes:}

BATAILLE sur le grand fleuve. Direção de Jean Rouch, 1950.

CRÔNICA de um Verão. Direção Jean Rouch e Edgar Morin,1960

HISTOIRE(S) du Cinema. Direção de Jean-Luc Godard, 1980-1988

LES glaneur et les glaunese. Direção de Agners Varda, 2000.

MARTÍRIO. Direção de Vincent Carelli, 2016.

MOI un noir. Direção de Jean Rouch, 1958.

O HOMEN com a câmera de filmar. Direção de Dziga Vertov, 1929.

O LIVROde cabeceira, Direção de Peter Greenaway, 1996.

THE TULSELupper suitcases, direção de Peter Greenaway, 2003-2005.

OUT my Window. Dirigido por: Katerina Cizek. Disponível em: http://outmywindow.nfb.ca/ - /outmywindow .2010

SERRAS da Desordem. Direção: Andrea Tonacci. 2006.

QUE Viva México. Direção de Sergei Eisenstein, 1979.

XAPIRI. Direção de Bruce Albert, Gisela Motta, Laymert Garcia dos Santos, Leandro Lima, Stella Senra. 2012 
APENDICE A - Carta da comunidade Guarani-kaiowá de Pyelito-Kue.

\section{Carta da comunidade Guarani-Kaiowá de Pyelito Kue/Mbarakay-Iguatemi- MS para o Governo e Justiça do Brasil}

Nós (50 homens, 50 mulheres e 70 crianças) comunidades Guarani-Kaiowá originárias de tekoha Pyelito kue/Mbrakay, viemos através desta carta apresentar a nossa situação histórica e decisão definitiva diante de da ordem de despacho expressado pela Justiça Federal de Navirai-MS, conforme o processo $\mathrm{n}^{\mathrm{o}}$ 0000032-87.2012.4.03.6006, do dia 29 de setembro de 2012. Recebemos a informação de que nossa comunidade logo será atacada, violentada e expulsa da margem do rio pela própria Justiça Federal, de Navirai-MS.

Assim, fica evidente para nós, que a própria ação da Justiça Federal gera e aumenta as violências contra as nossas vidas, ignorando os nossos direitos de sobreviver à margem do rio Hovy e próximo de nosso território tradicional Pyelito Kue/Mbarakay. Entendemos claramente que esta decisão da Justiça Federal de Navirai-MS é parte da ação de genocídio e extermínio histórico ao povo indígena, nativo e autóctone do Mato Grosso do Sul, isto é, a própria ação da Justiça Federal está violentando e exterminado e as nossas vidas. Queremos deixar evidente ao Governo e Justiça Federal que por fim, já perdemos a esperança de sobreviver dignamente e sem violência em nosso território antigo, não acreditamos mais na Justiça brasileira. A quem vamos denunciar as violências praticadas contra nossas vidas? Para qual Justiça do Brasil? Se a própria Justiça Federal está gerando e alimentando violências contra nós. Nós já avaliamos a nossa situação atual e concluímos que vamos morrer todos mesmo em pouco tempo, não temos e nem teremos perspectiva de vida digna e justa tanto aqui na margem do rio quanto longe daqui. Estamos aqui acampados a 50 metros do rio Hovy onde já ocorreram quatro mortes, sendo duas por meio de suicídio e duas em decorrência de espancamento e tortura de pistoleiros das fazendas.

Moramos na margem do rio Hovy há mais de um ano e estamos sem nenhuma assistência, isolados, cercado de pistoleiros e resistimos até hoje. Comemos comida uma vez por dia. Passamos tudo isso para recuperar o nosso território antigo Pyleito Kue/Mbarakay. De fato, sabemos muito bem que no centro desse nosso território antigo estão enterrados vários os nossos avôs, avós, bisavôs e bisavós, ali estão os cemitérios de todos nossos antepassados.

Cientes desse fato histórico, nós já vamos e queremos ser mortos e enterrados junto aos nossos antepassados aqui mesmo onde estamos hoje, por isso, pedimos ao Governo e Justiça Federal para não decretar a ordem de despejo/expulsão, mas solicitamos para decretar a nossa morte coletiva e para enterrar nós todos aqui. 
Pedimos, de uma vez por todas, para decretar a nossa dizimação e extinção total, além de enviar vários tratores para cavar um grande buraco para jogar e enterrar os nossos corpos. Esse é nosso pedido aos juízes federais. Já aguardamos esta decisão da Justiça Federal. Decretem a nossa morte coletiva Guarani e Kaiowá de Pyelito Kue/Mbarakay e enterrem-nos aqui. Visto que decidimos integralmente a não sairmos daqui com vida e nem mortos.

Sabemos que não temos mais chance em sobreviver dignamente aqui em nosso território antigo, já sofremos muito e estamos todos massacrados e morrendo em ritmo acelerado. Sabemos que seremos expulsos daqui da margem do rio pela Justiça, porém não vamos sair da margem do rio. Como um povo nativo e indígena histórico, decidimos meramente em sermos mortos coletivamente aqui. Não temos outra opção esta é a nossa última decisão unânime diante do despacho da Justiça Federal de Navirai-MS.

Atenciosamente, Guarani-Kaiowá de Pyelito Kue/Mbarakay

\section{Relatório do conselho Aty Guasu explica a situação dos Guarani Kaiowá de Pyelito Kue/Mbarakay}

Este relatório é do conselho da Aty Guasu Guarani e Kaiowá, explicitando a história e situação atual de vida dos integrantes das comunidades GuaraniKaiowá do território tradicional Pyelito Kue/Mbarakay, localizada na margem de Rio Hovy, 50 metros do rio Hovy, no município de Iguatemi-MS. 0 acampamento da comunidade guarani e kaiowá de Pyelito Kue/Mbarakay começou no dia 08 de agosto de 2011.

É importante ressaltar que os membros (crianças, mulheres e idosos) dessa comunidade proveniente de uma reocupação, no dia 23 de agosto de 2011, às $20 \mathrm{~h} 00$, foram atacados de modo violentos e cruéis pelos pistoleiros das fazendas. A mando dos fazendeiros, os homens armados passaram permanentemente a ameaçar e cercar a área minúscula reocupada pela comunidade Guarani-Kaiowá na margem do rio que este fato perdura até hoje.

Em um ano, os pistoleiros que cercam o acampamento das famílias guaranikaiowá, já cortaram/derrubaram 10 vezes a ponte móvel feito de arame/cipó que é utilizada pelas comunidades para atravessar um rio com a largura de 30 metros largura e mais de 3 metros de fundura. Apesar desse isolamento pistoleiros armados ameaçam constantemente os indígenas, porém 170 comunidades indígenas reocupante do território antigo Pyelito kue continuam resistindo e sobrevivendo na margem do rio Hovy na pequena área reocupada até os dias de hoje, estão aguardando a demarcação definitiva do território antigo Pyelito Kue/Mbarakay.

No dia 8 dezembro de 2009, este grupo já foi espancado, ameaçado com armas de fogo, vendado e jogado à beira da estrada em uma desocupação extra-judicial, promovida por um grupo de pistoleiros a mando de fazendeiros da região de Iguatemi-MS. Antes, em julho de 2003, um grupo indígena já havia tentado retornar, sendo expulso por pistoleiros das fazendas da região, que invadiram o acampamento dos indígenas, torturaram e fraturaram as pernas e os braços das 
mulheres, crianças e idosos. Em geral os Guarani e Kaiowa são hoje cerca de 50 mil pessoas, ocupando apenas 42 mil hectares. A falta de terras regularizadas tem ocasionado uma série de problemas sociais entre eles, ocasionando uma crise humanitária, com altos índices de mortalidade infantil, violência e suicídios entre jovens.

No último mês a Justiça Federal de Navirai-MS, deferiu liminar de despejo da comunidade Guarani e Kaiowá da margem do rio Hovy solicitado pelo advogado dos fazendeiros e, no despacho cita "reintegração de posse", mas observamos que o grupo indígena está assentado na margem do rio Hovy, ou seja, não estão no interior da fazenda como alega o advogado dos fazendeiros. De fato, não procede à argumentação dos fazendeiros e por sua vez do juiz federal de Navirai sem verificar o fato relatado, deferir a reintegração de posse. Não é possível despejar indígenas da margem de um rio. Por isso pedimos para Justiça rever a decisão de juiz de Navirai-MS.

No sentido amplo, nos conselhos da Aty Guasu recebemos a carta da comunidade de Pyelito Kue/Mbarakay em que consta a decisão da comunidade que passamos divulgar a todas as autoridades federais e sociedade brasileira.

Tekoha Pyelito kue/Mbarakay, 08 de outubro de 2012

Atenciosamente,

Conselho/Comissão de Aty Guasu Guarani e Kaiowá do MS.

APENDICE B - Juanahú entrega o dvd do filme Berahatxi-rbi Olodu Mahadu a Beialari (foto: Caio Lazaneo)

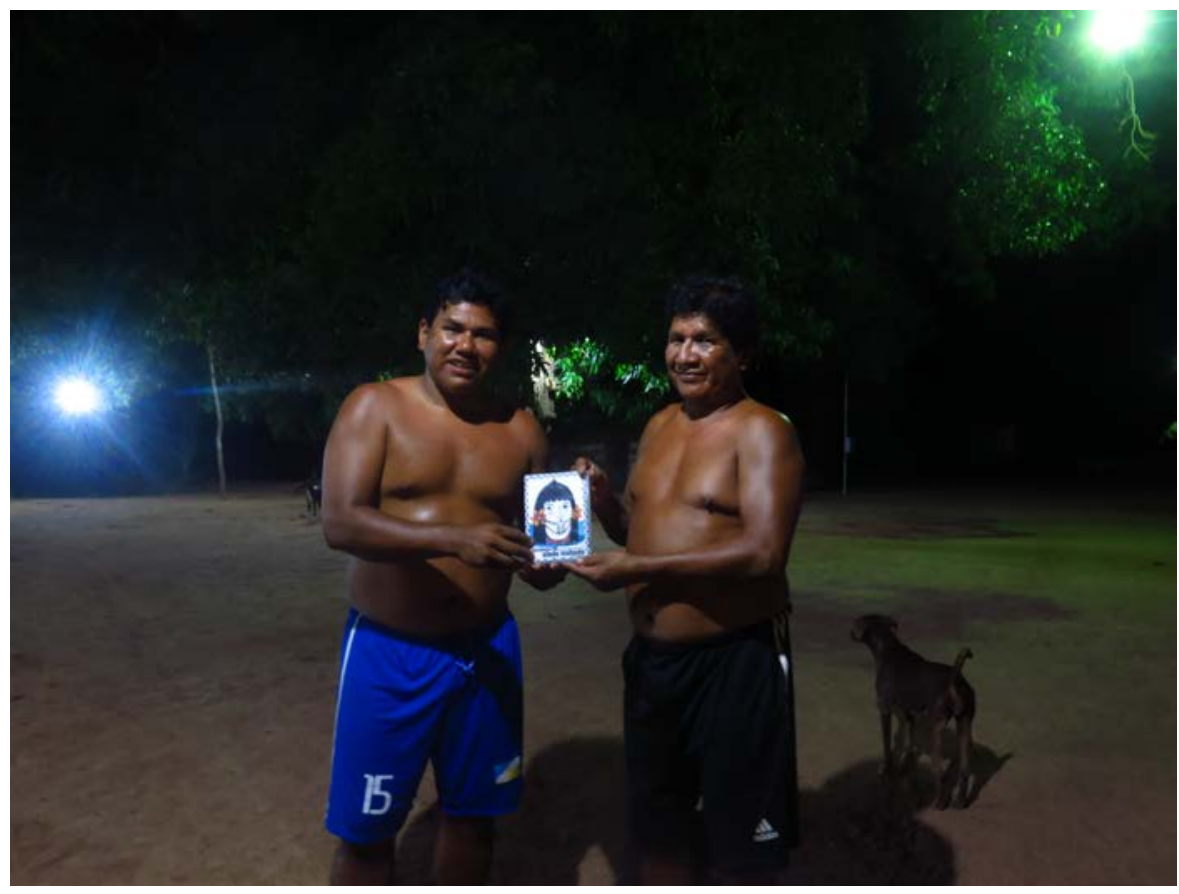


APENDICE C - Futebol tori-iny (foto: Caio Luiz)

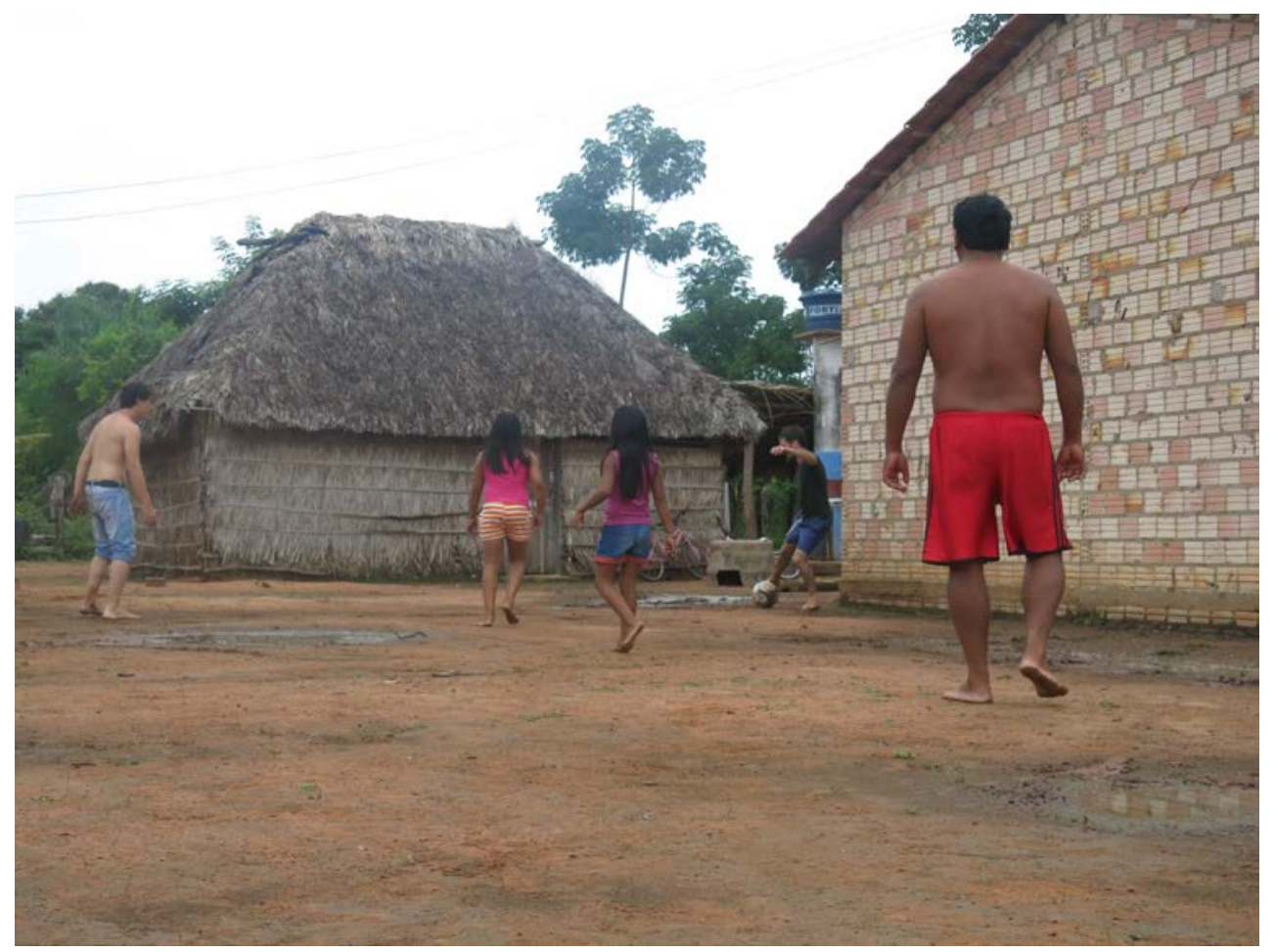

APENDICE D - Futebol tori-iny (foto: Caio Luiz)

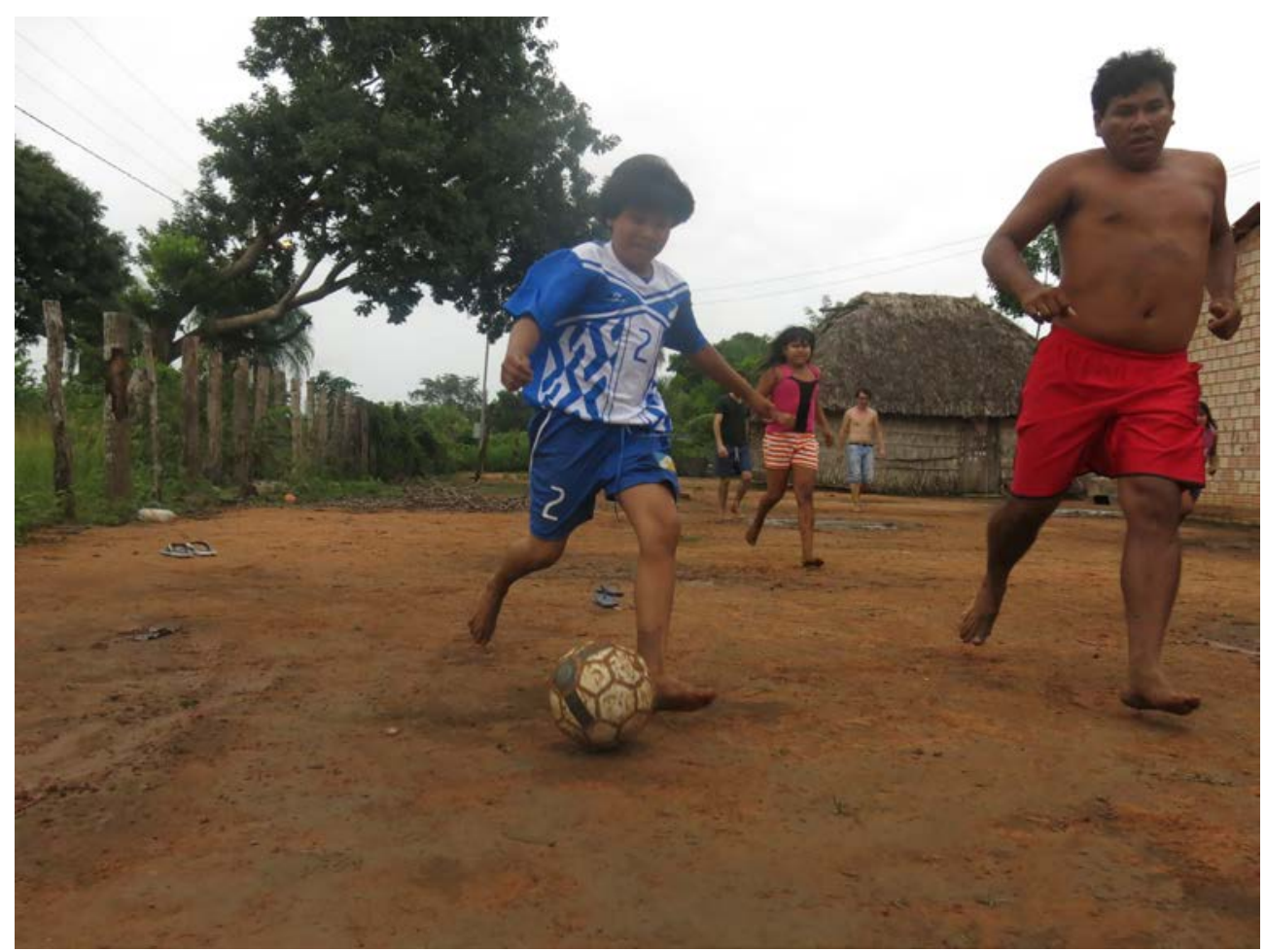


APENDICE E - Gravações (foto: Caio Luiz)

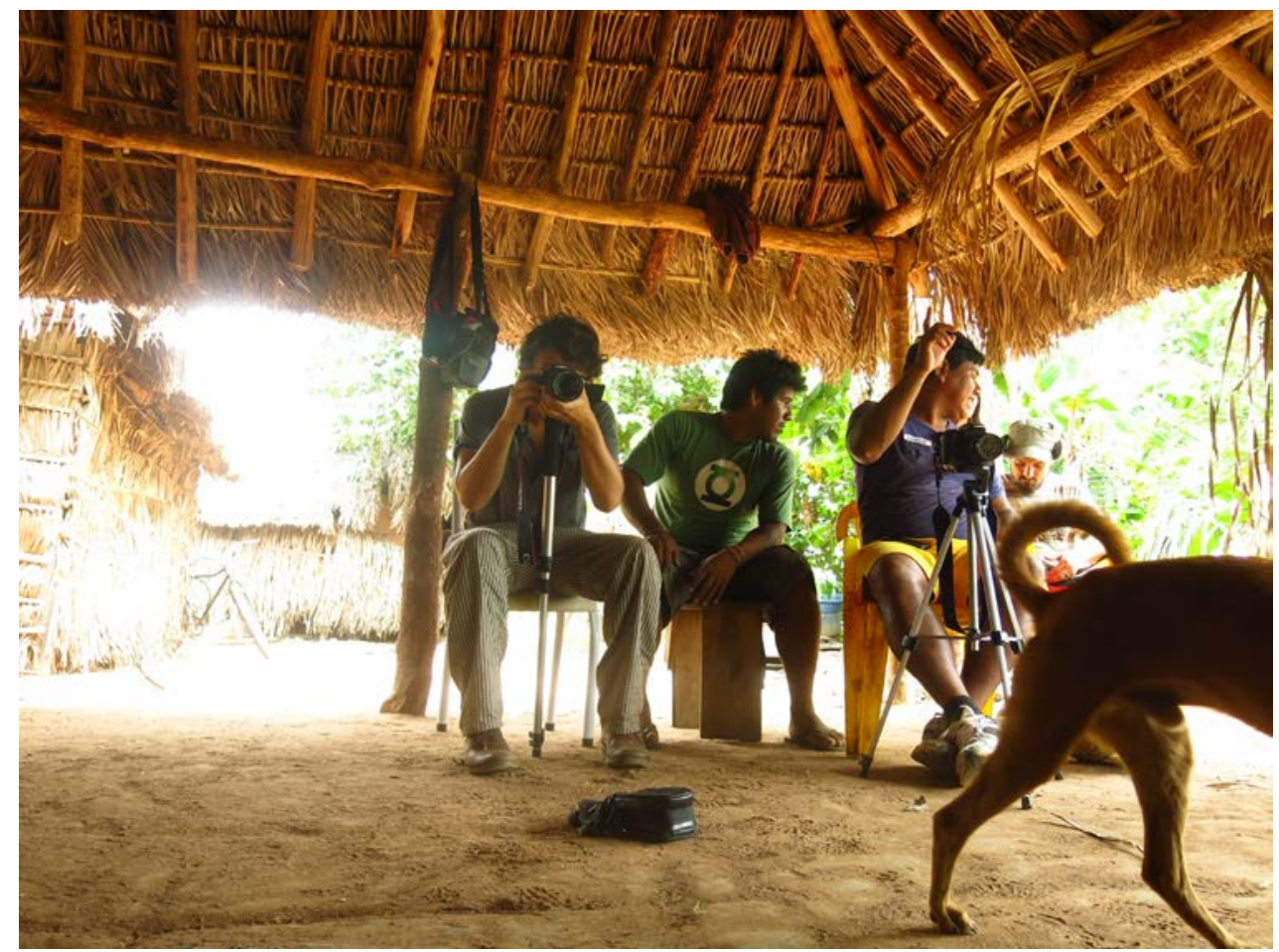

APENDICE F - Igreja Adventista de Hawalo (foto: Caio Lazaneo)

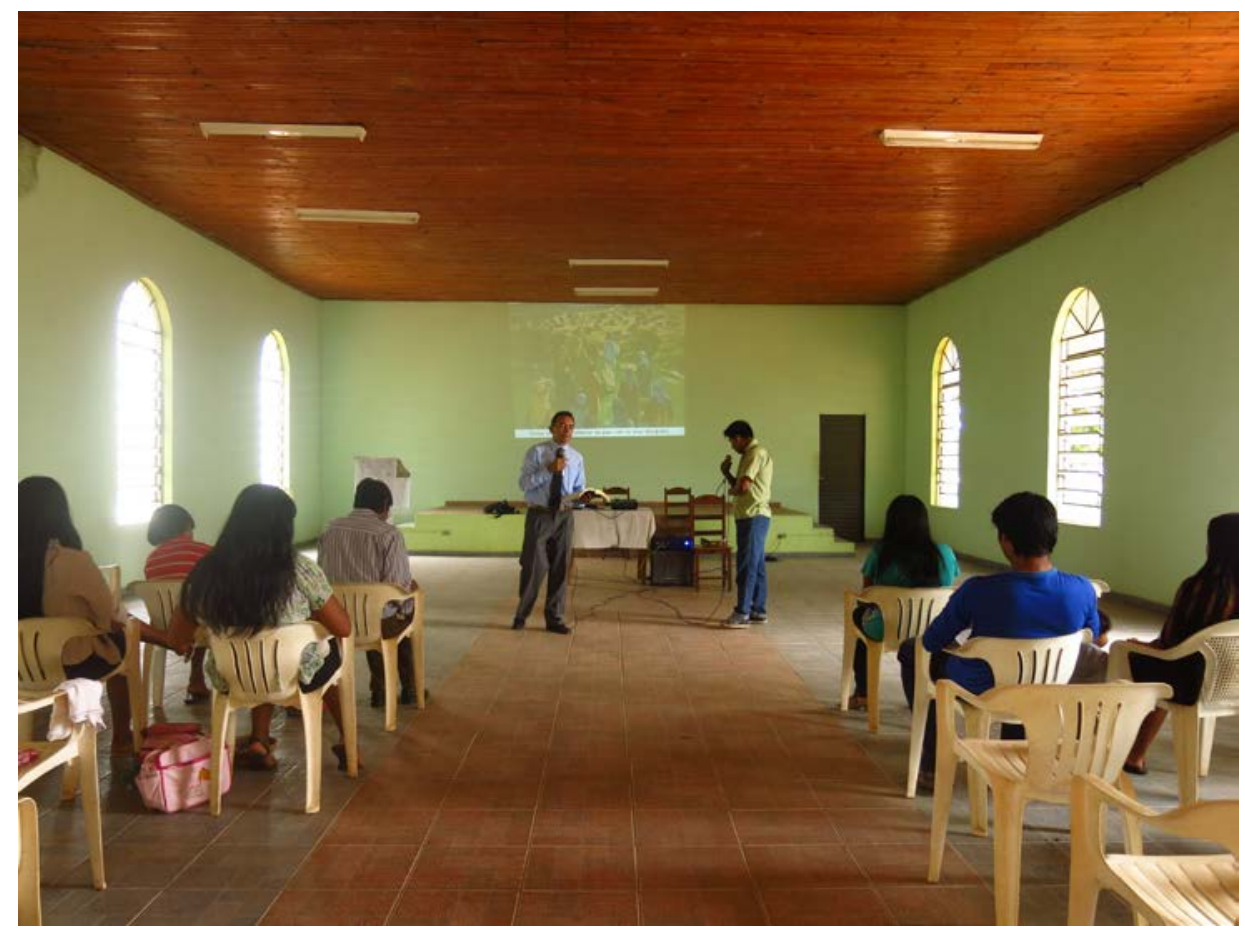


APENDICE G - Ixyse e sua filha Kuanadiki (Foto: Caio Lazaneo)

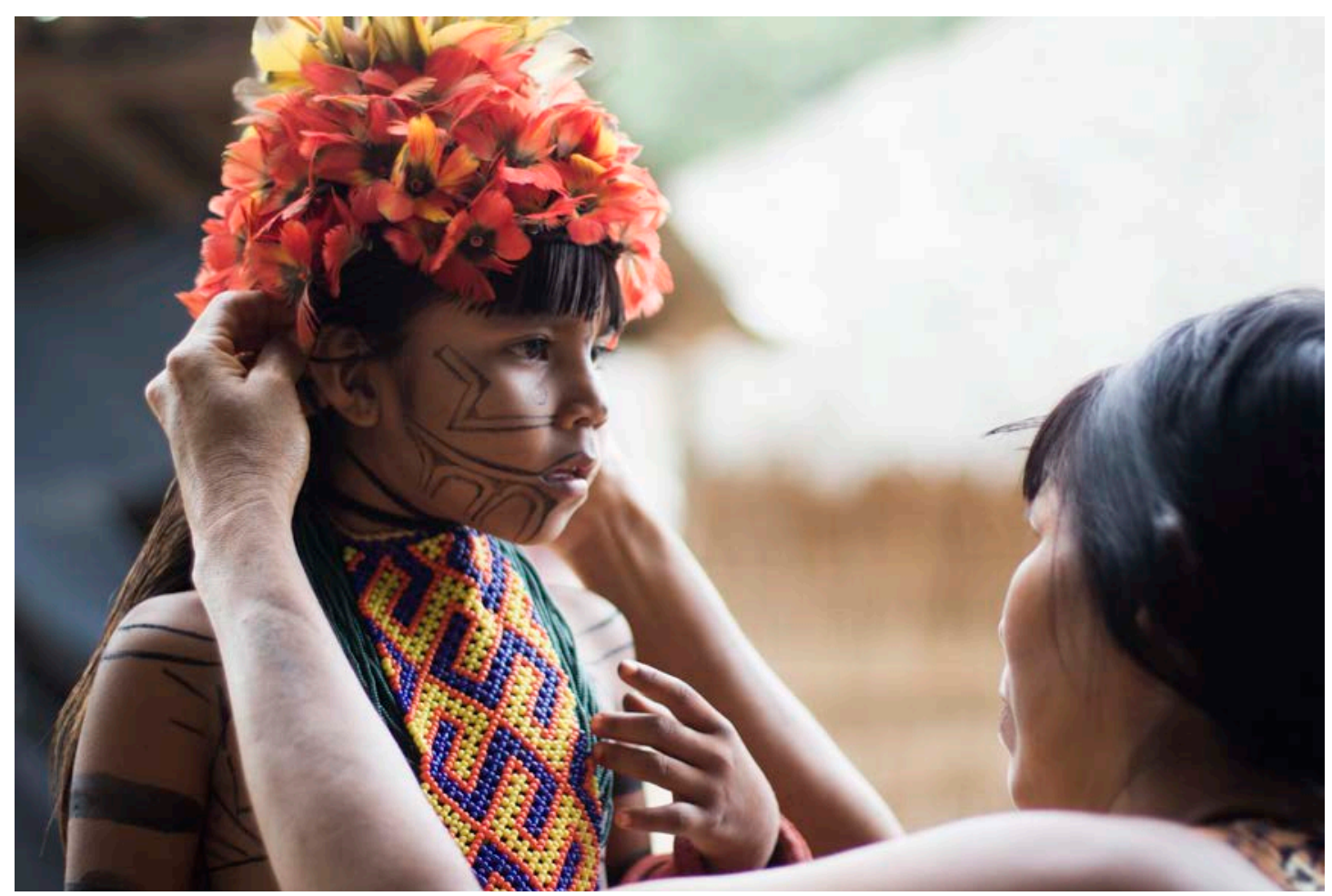

APENDICE H - Caio Lazaneo mostra foto para Ixyse e sua filha Kuanadiki (Foto: Yudji Oliveira)

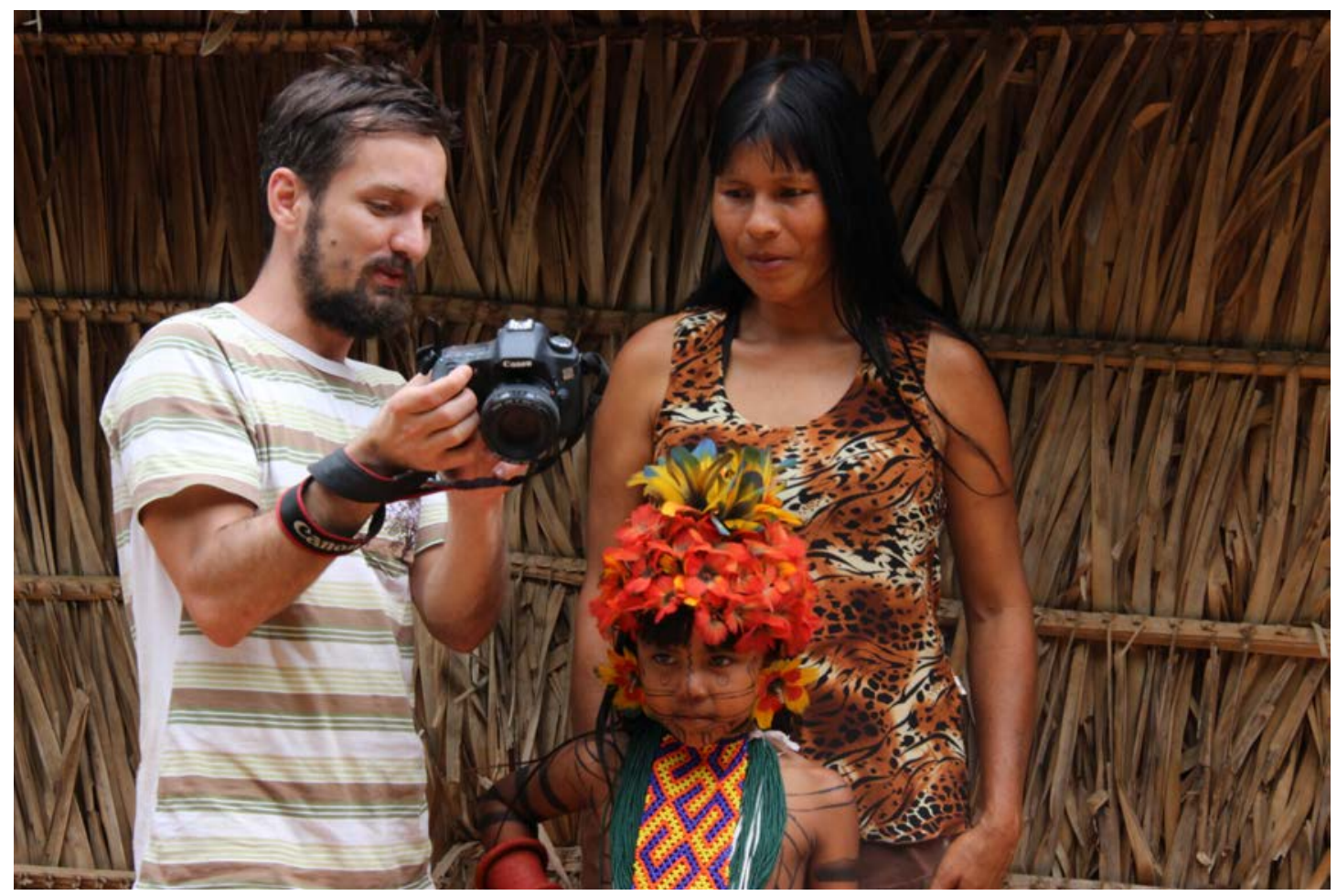


APENDICE I - Gravação na casa do hyrí Sokrowé. Da esquerda para direita: Caio Luiz, Juanahú Iny, Yudji Oliveira, Kuanadiki, Sokrowé, Ixyse e Caio Lazaneo. (foto automática).

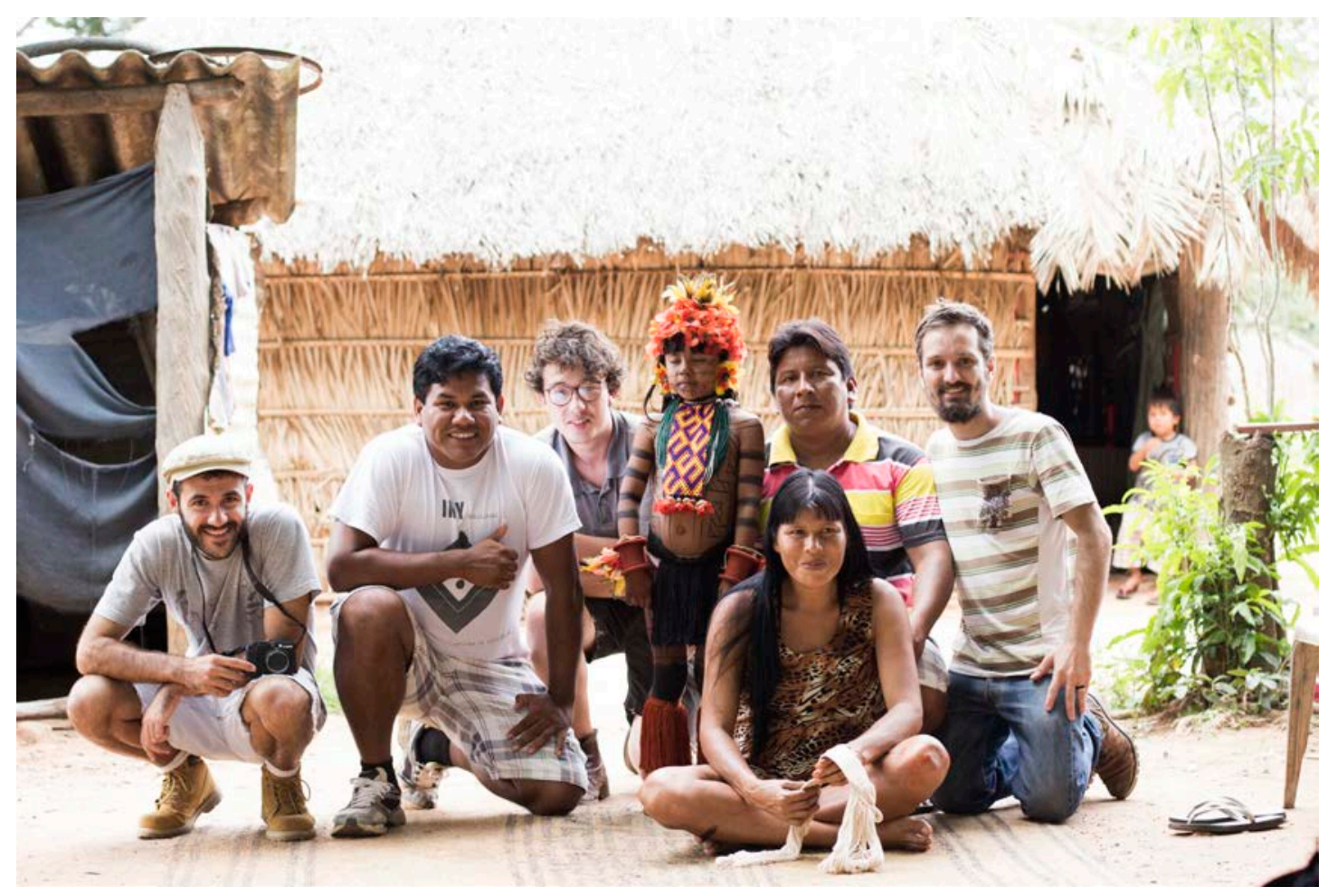

APENDICE J - Sessão de filmes indígenas projetados no hetô (Foto: Caio Lazaneo)

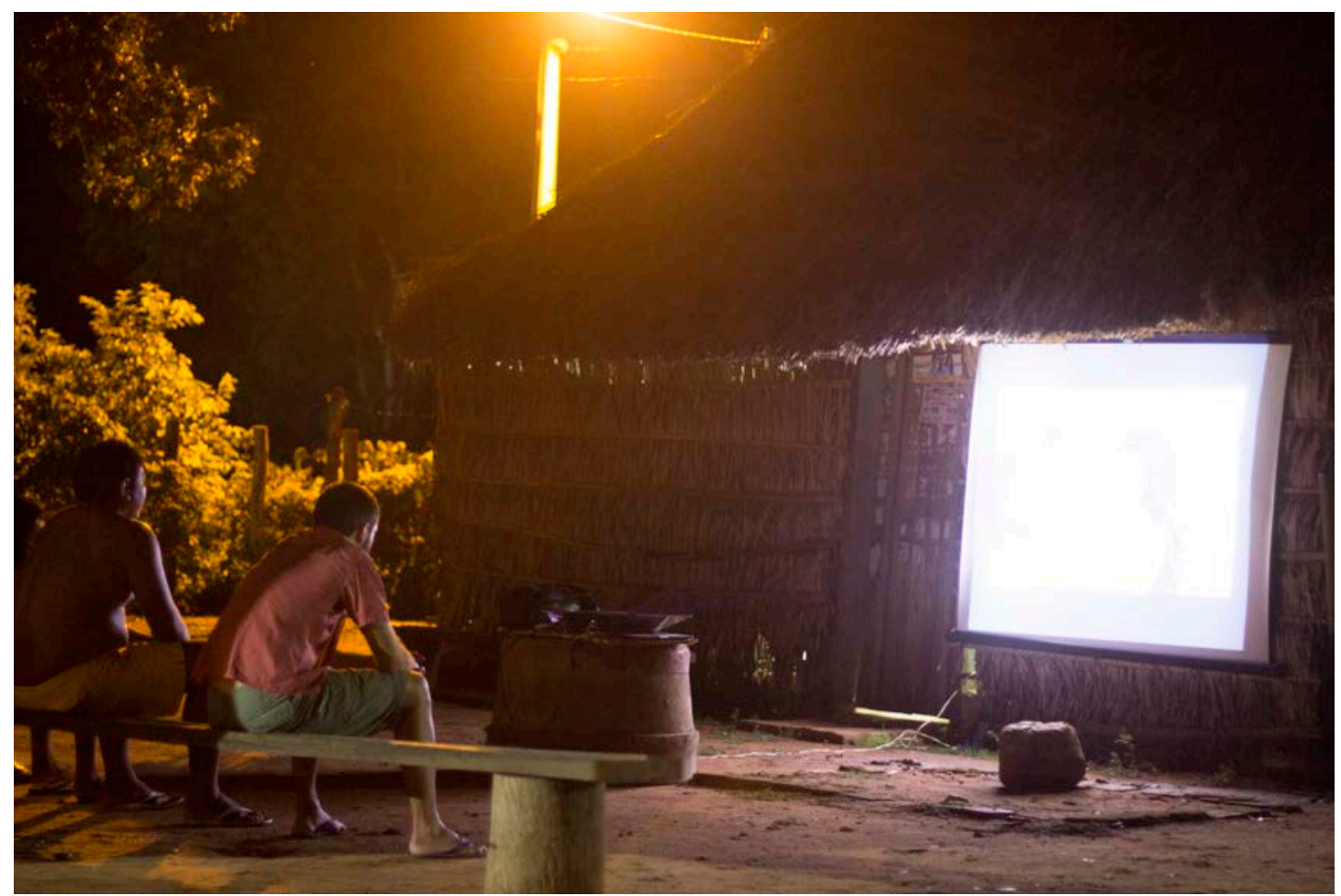


APENDICE L - Da esquerda para direita: Caio Lazaneo, Caio Luiz, Yudji Oliveira, Juanahú Iny, Mirna e Woujiji. (foto automática)

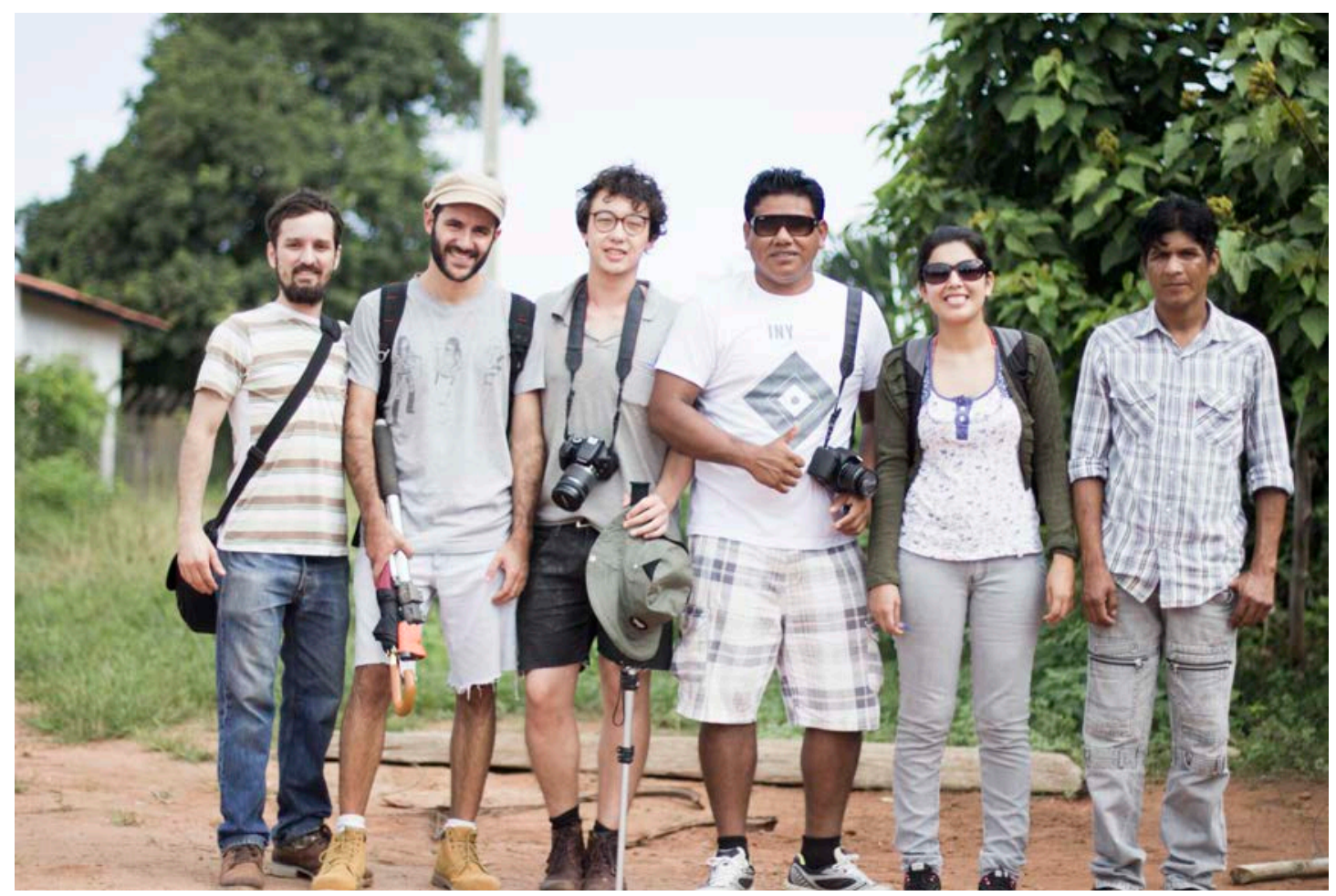

APENDICE M - Da esquerda para direita: Caio Lazaneo, Juanahú Iny e Caio Luiz (Foto: Yudji Oliveira)

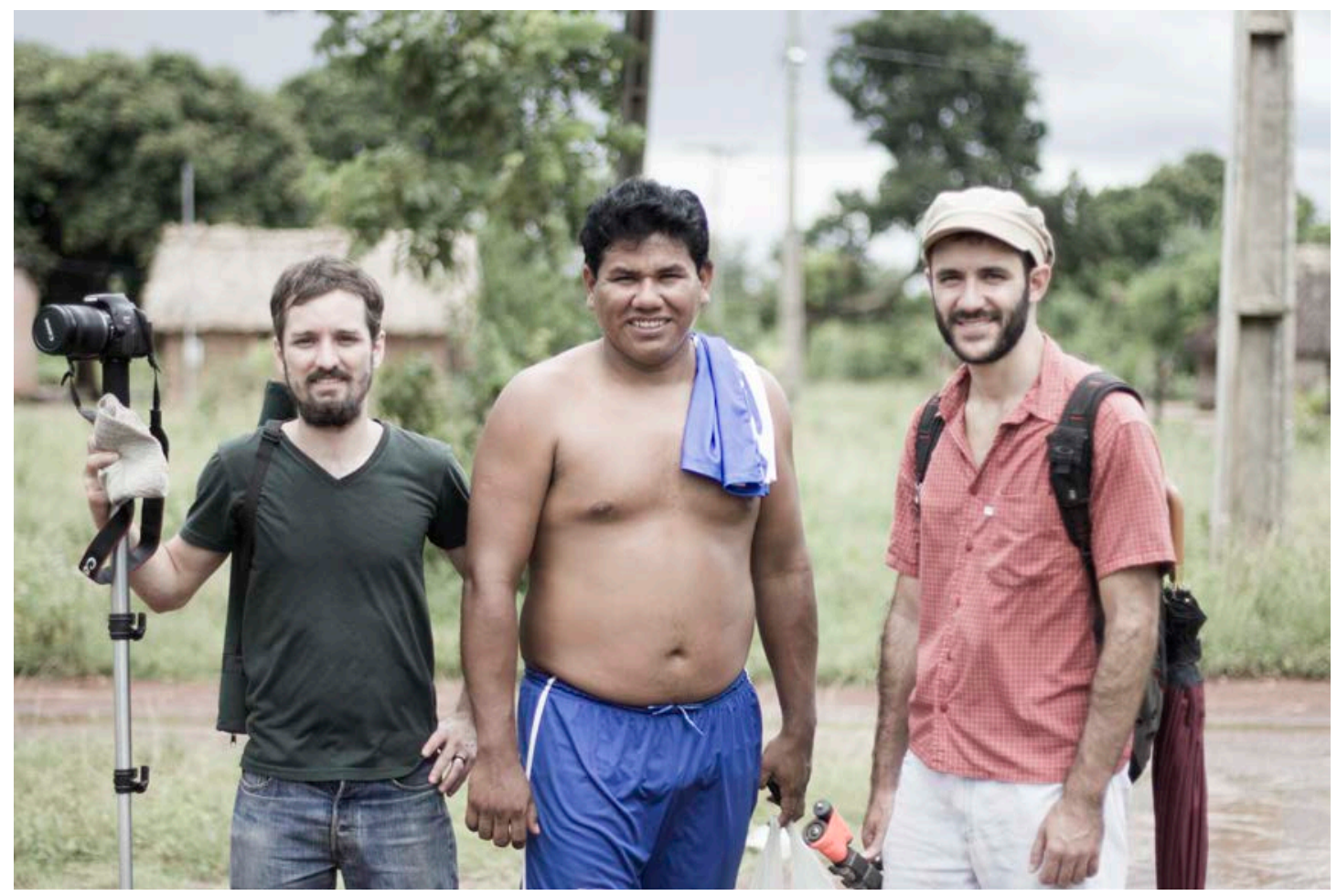


APENDICE N - Gravação de conversa com cacique Iwraru (Foto: Juanahú Iny)

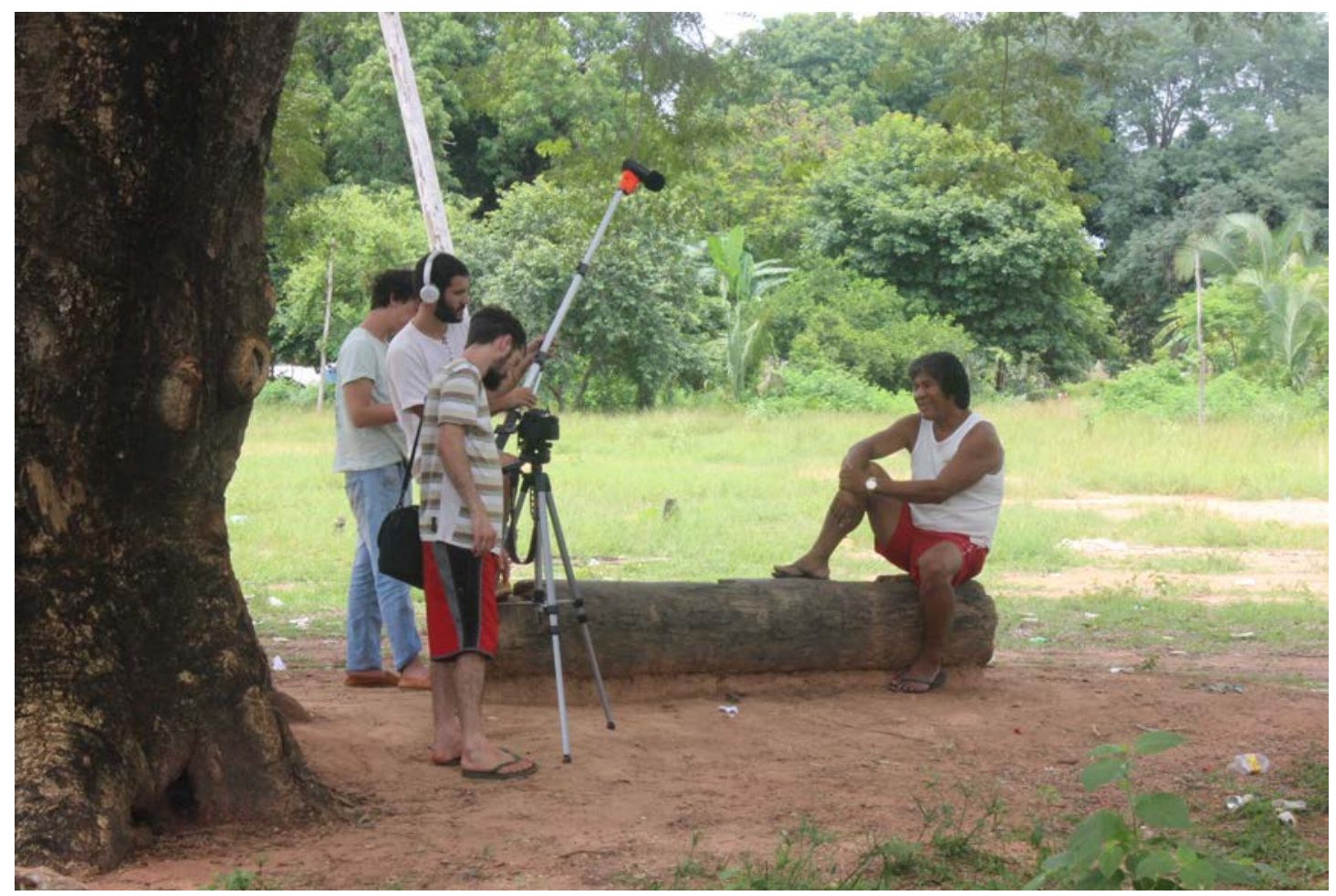

APENDICE 0 - Da esquerda para direita: Juanahú Iny, Caio Lazaneo e Divino Tserwahú. (Foto: Caio Luiz)

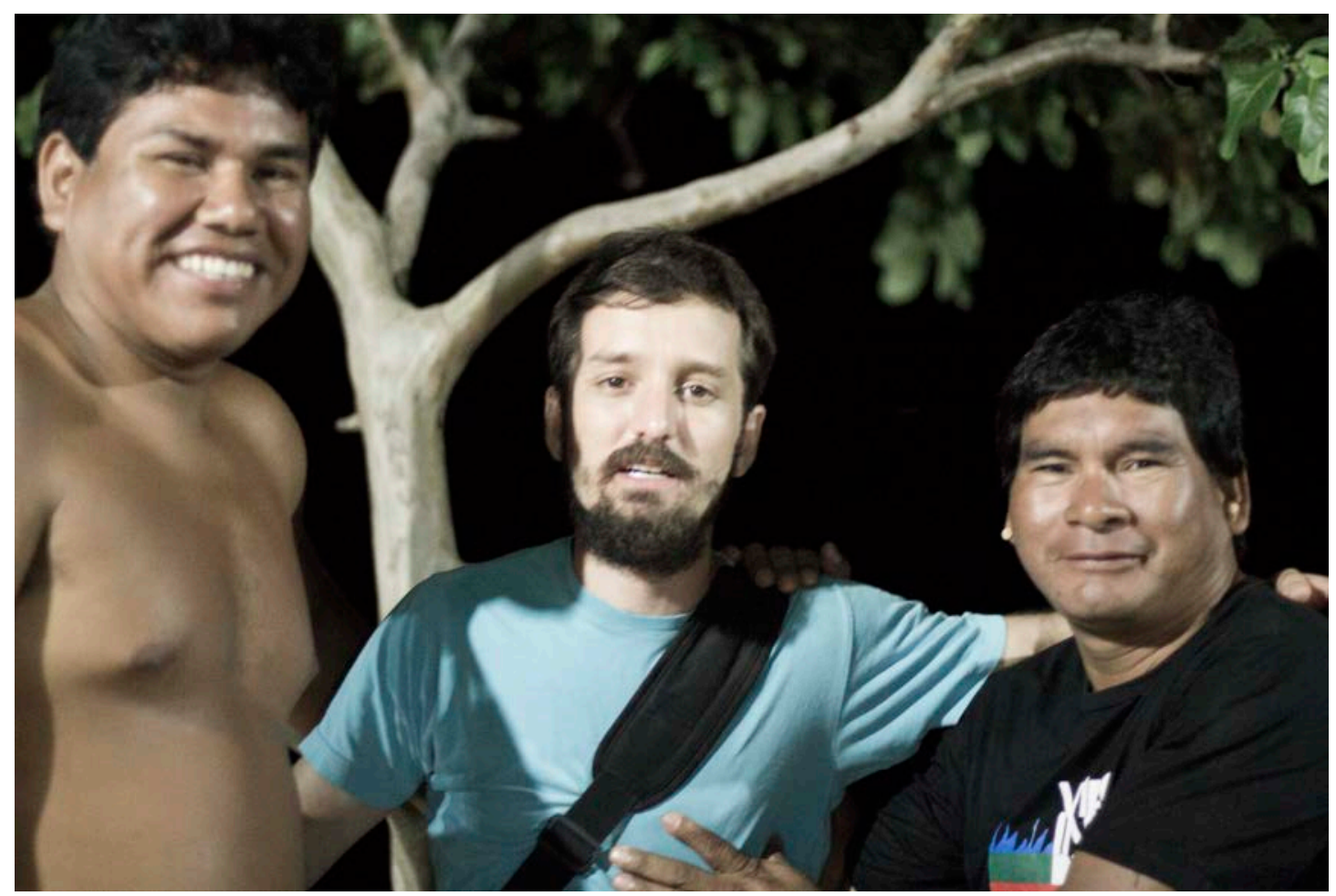


APENDICE P - Da esquerda para direita: Caio Lazaneo, Divino Tserewahú, Yudji Oliveira e Caio Luiz (Foto: Juanahú Iny)

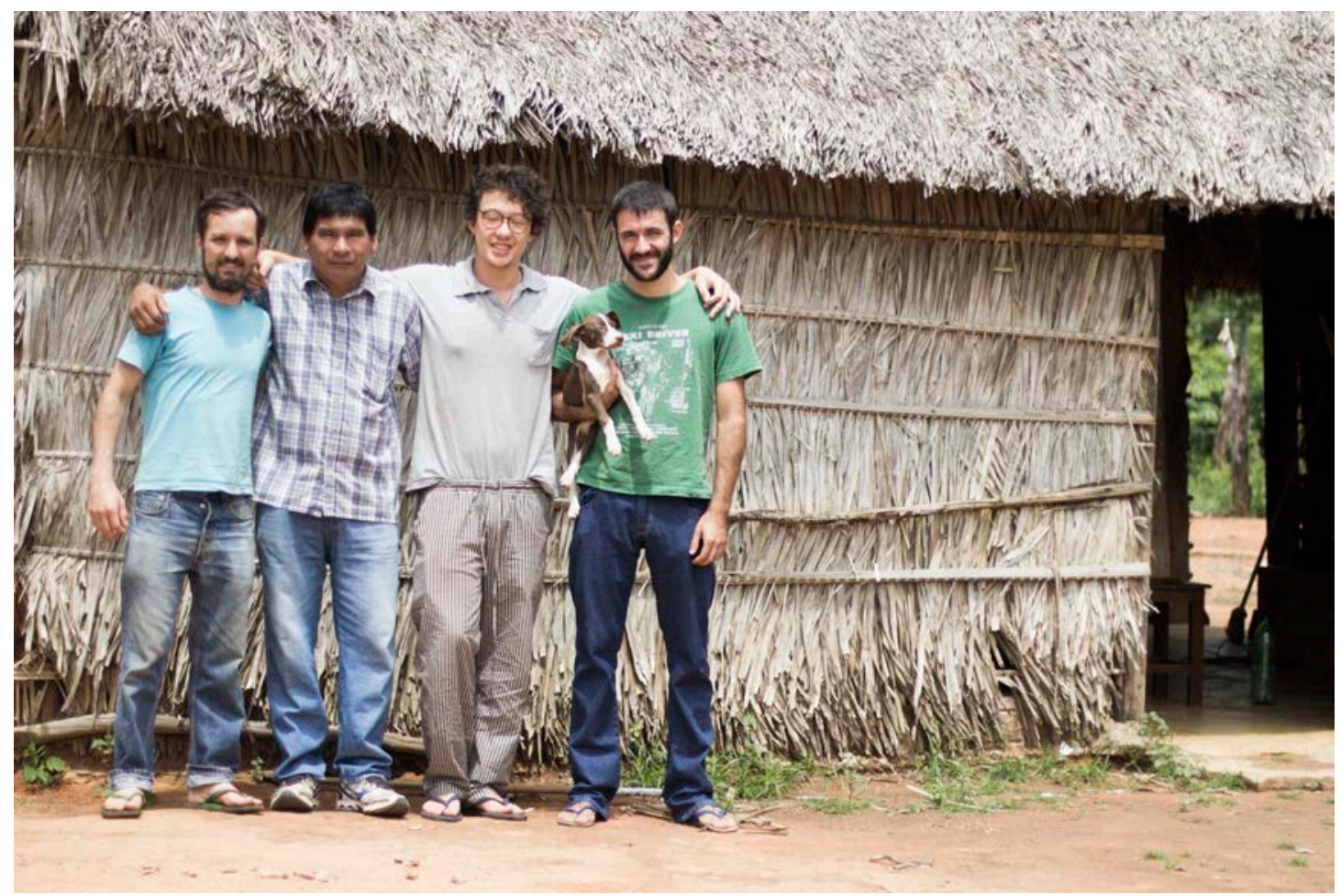

APENDICE Q - Waxiaki e sua pequena filha Wekuka (Foto: Caio Lazaneo)

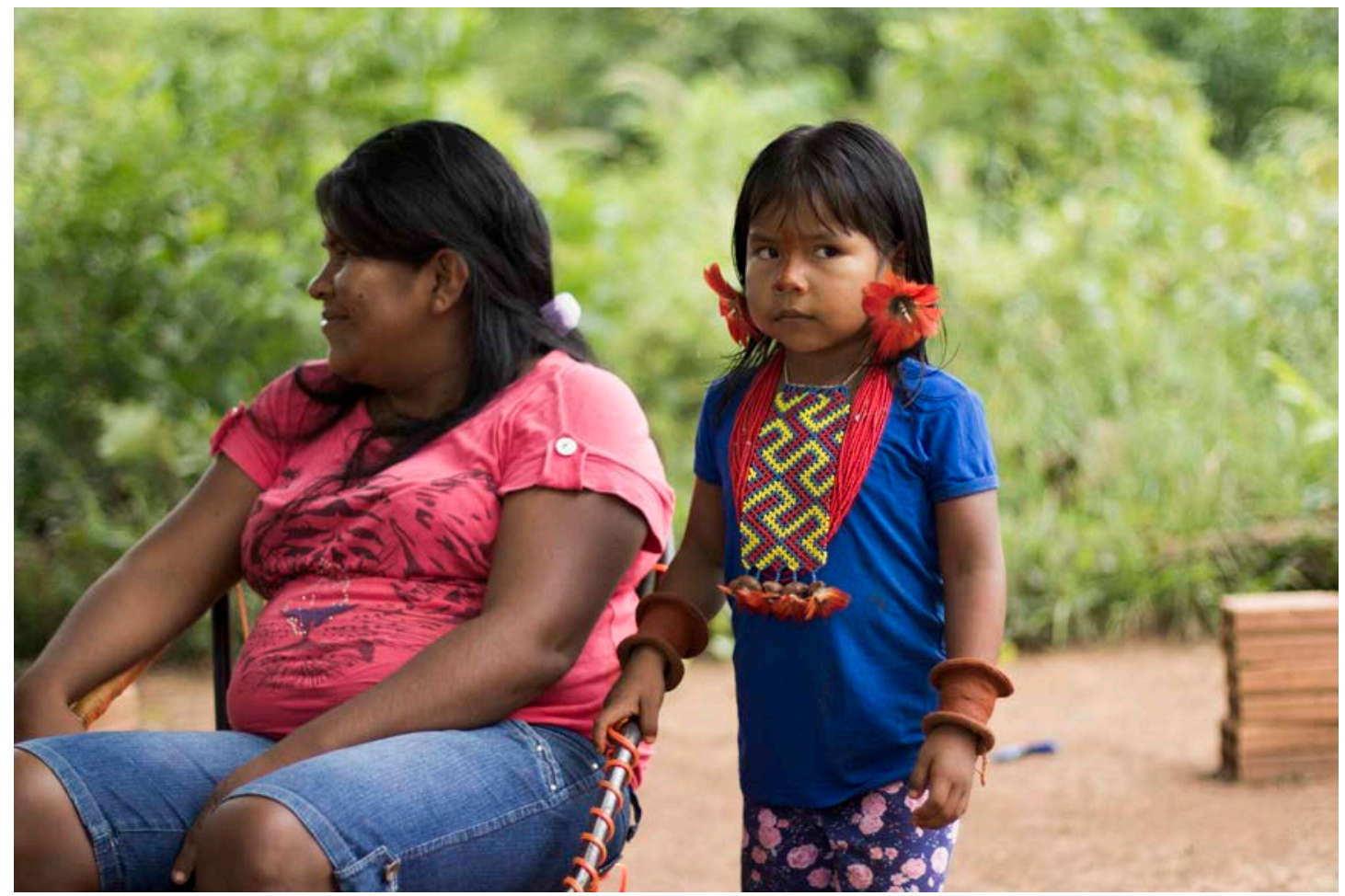


APENDICE R - O hyrí Sokrowé. (Foto: Caio Luiz)

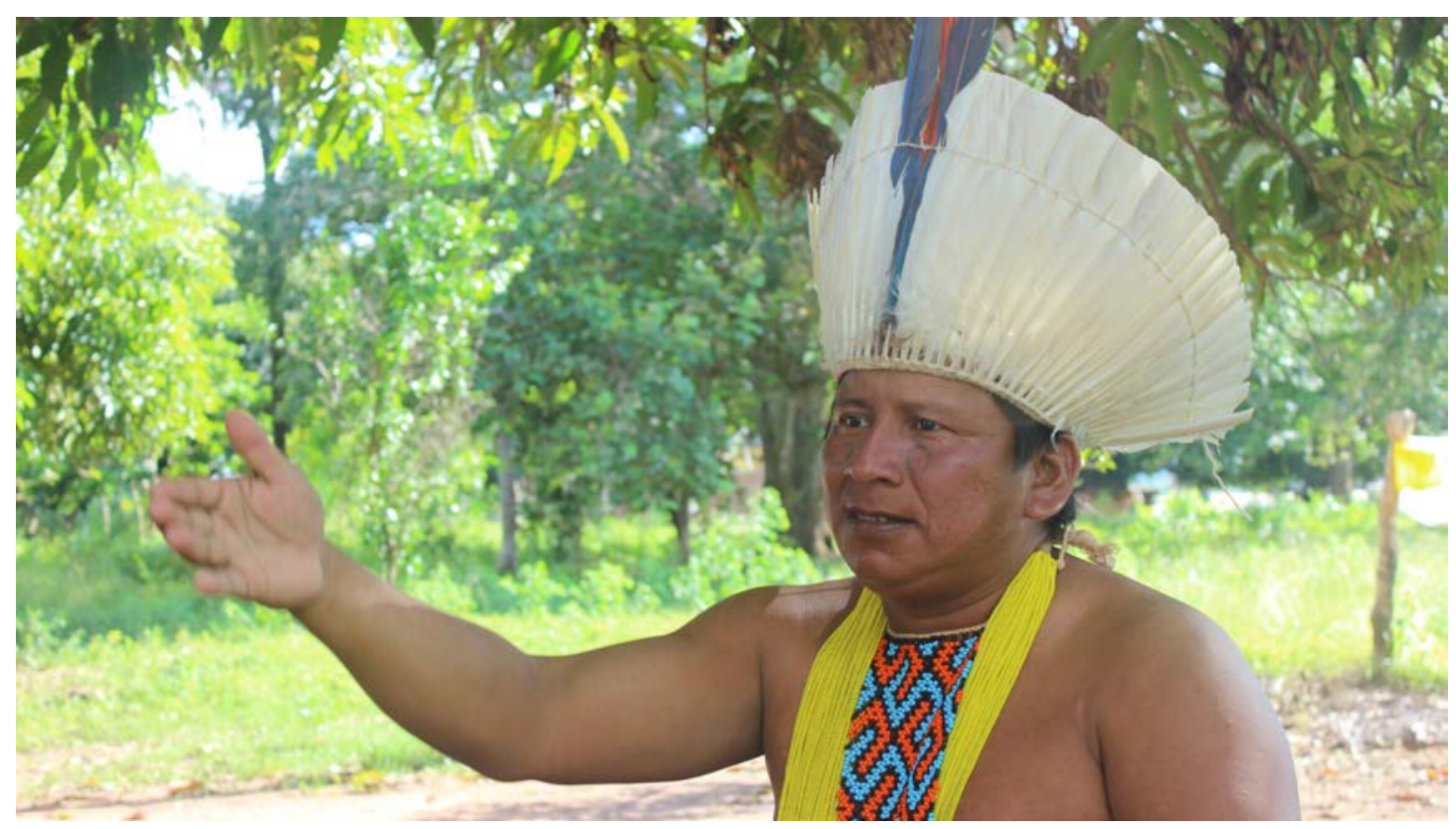

APENDICE S - Gravações da conversa entre Jua e Sokro (Foto: Yudji Oliveira)

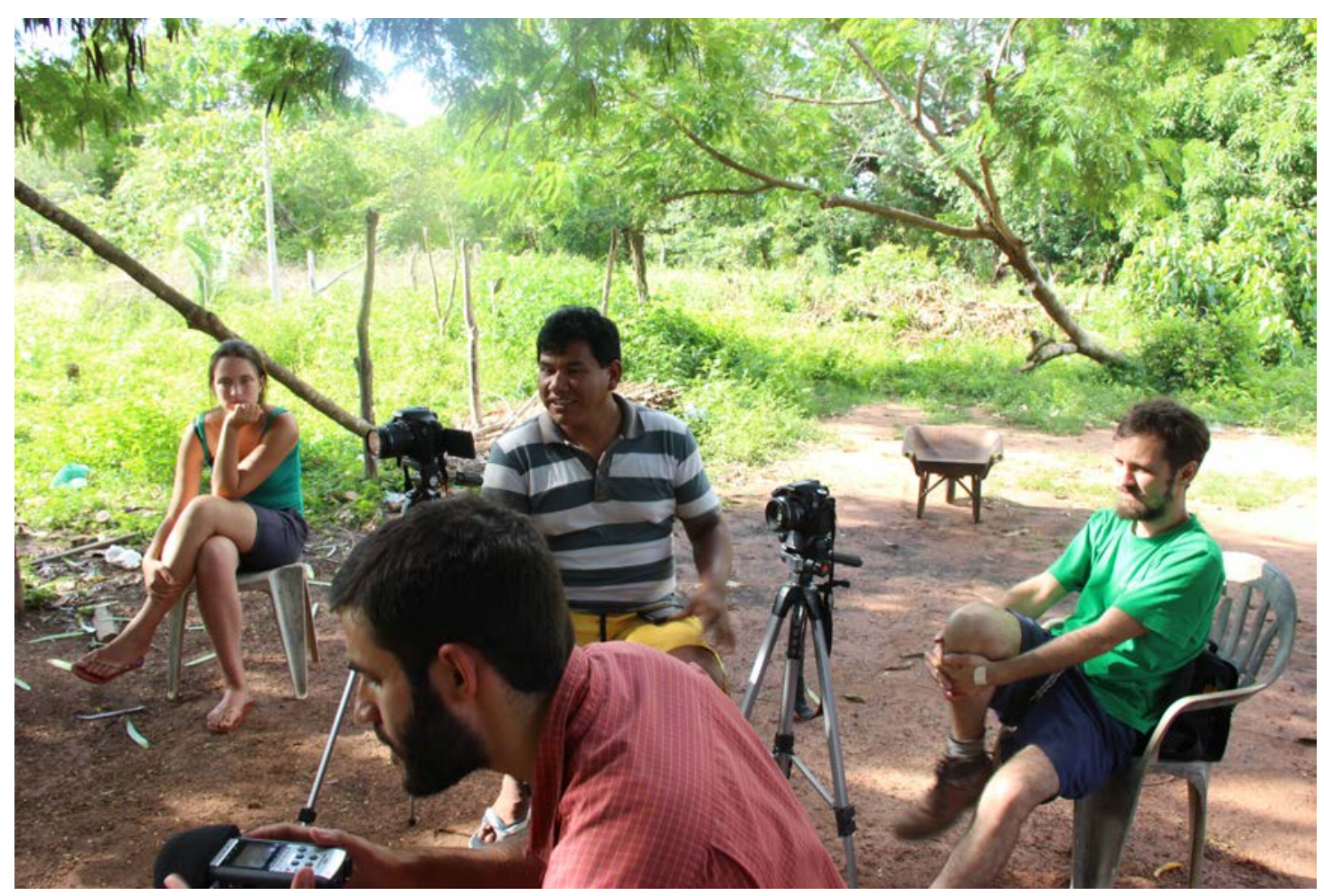


APENDICE T - Juanahú filma Sokrowé. (Foto: Caio Lazaneo)

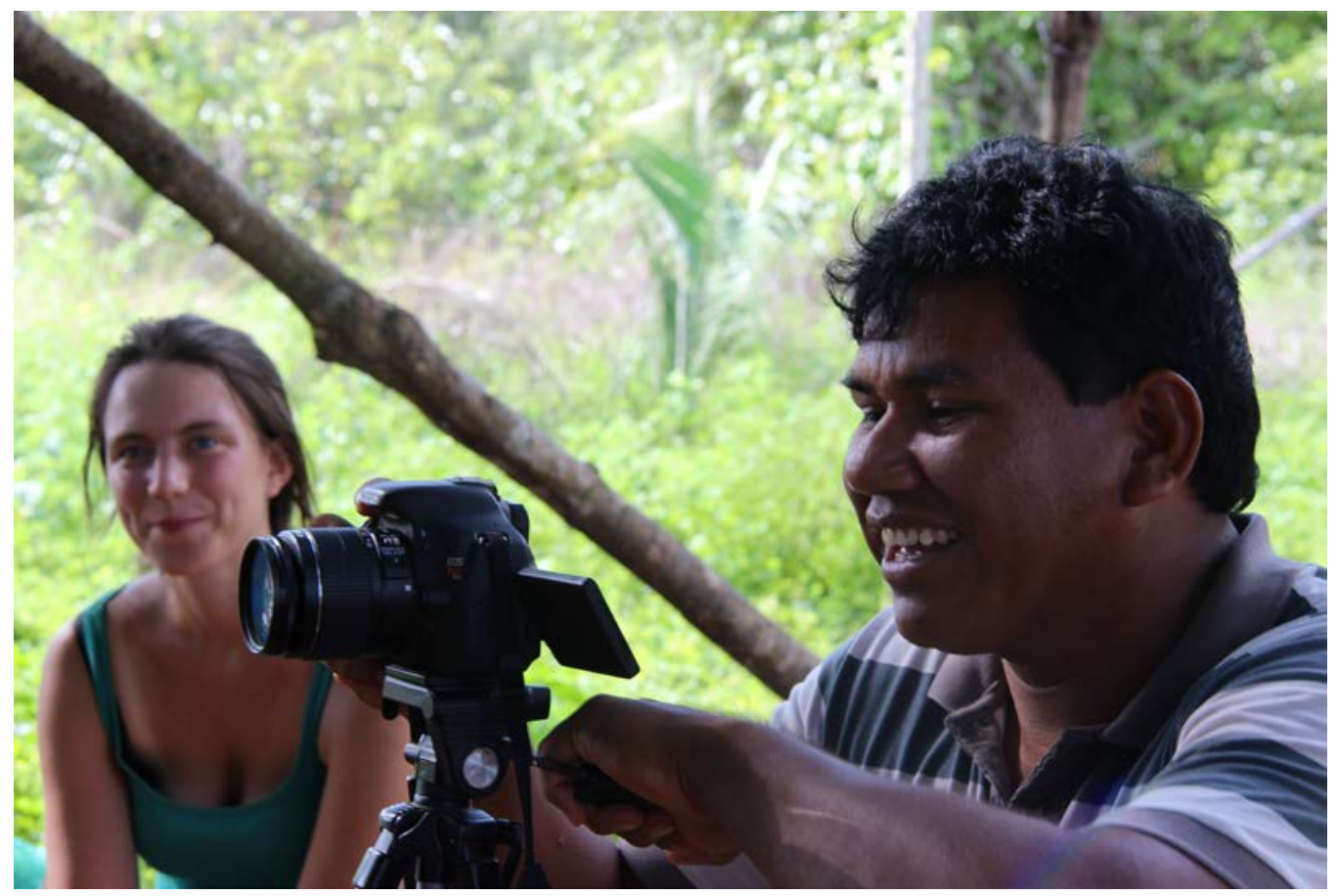

APENDICE U - O sorriso do hyrí Sokrowé. (Foto: Caio Luiz)

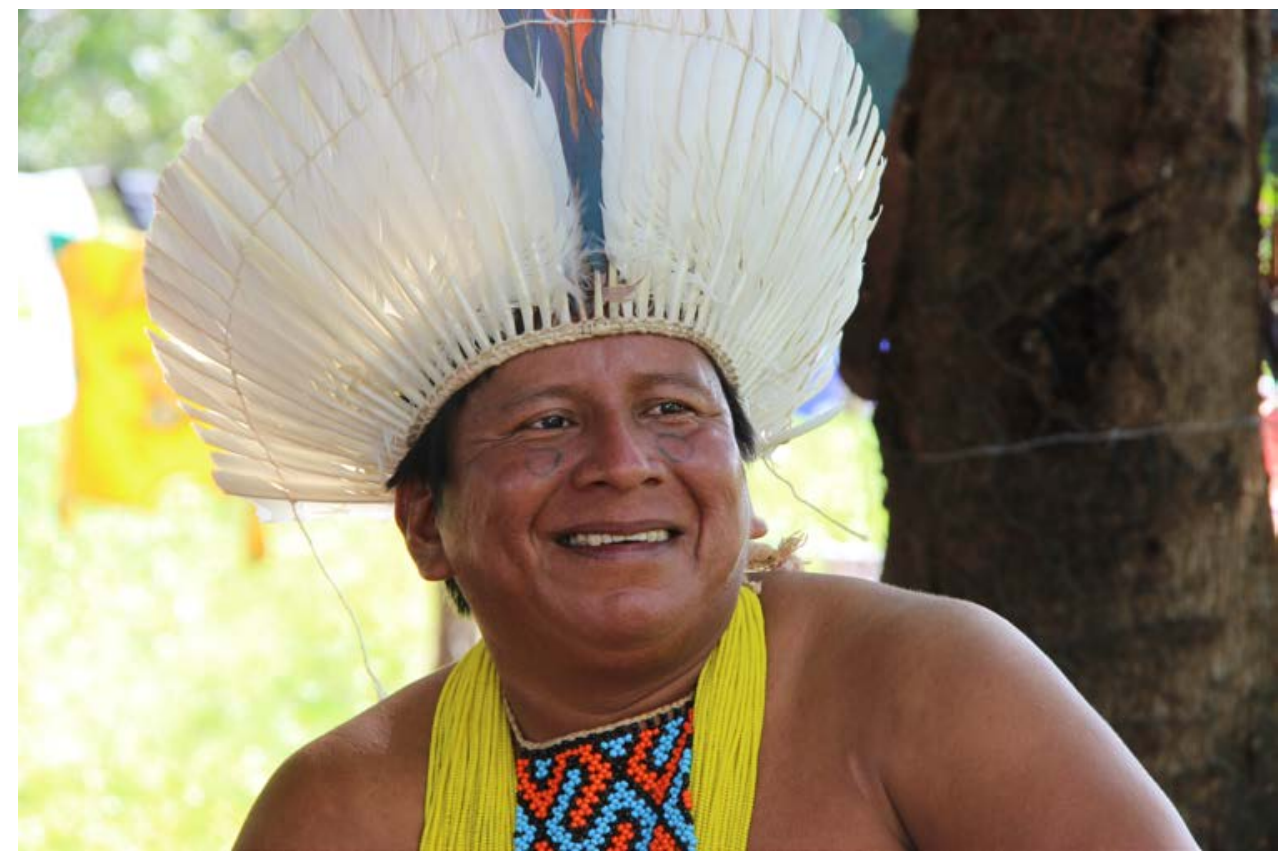


APENDICE V - Juanahú entre o dvd do filme Berahatxi-rbi Olodu Mahadu à Itxawyraru na aldeia Fontoura (foto: Caio Lazaneo)

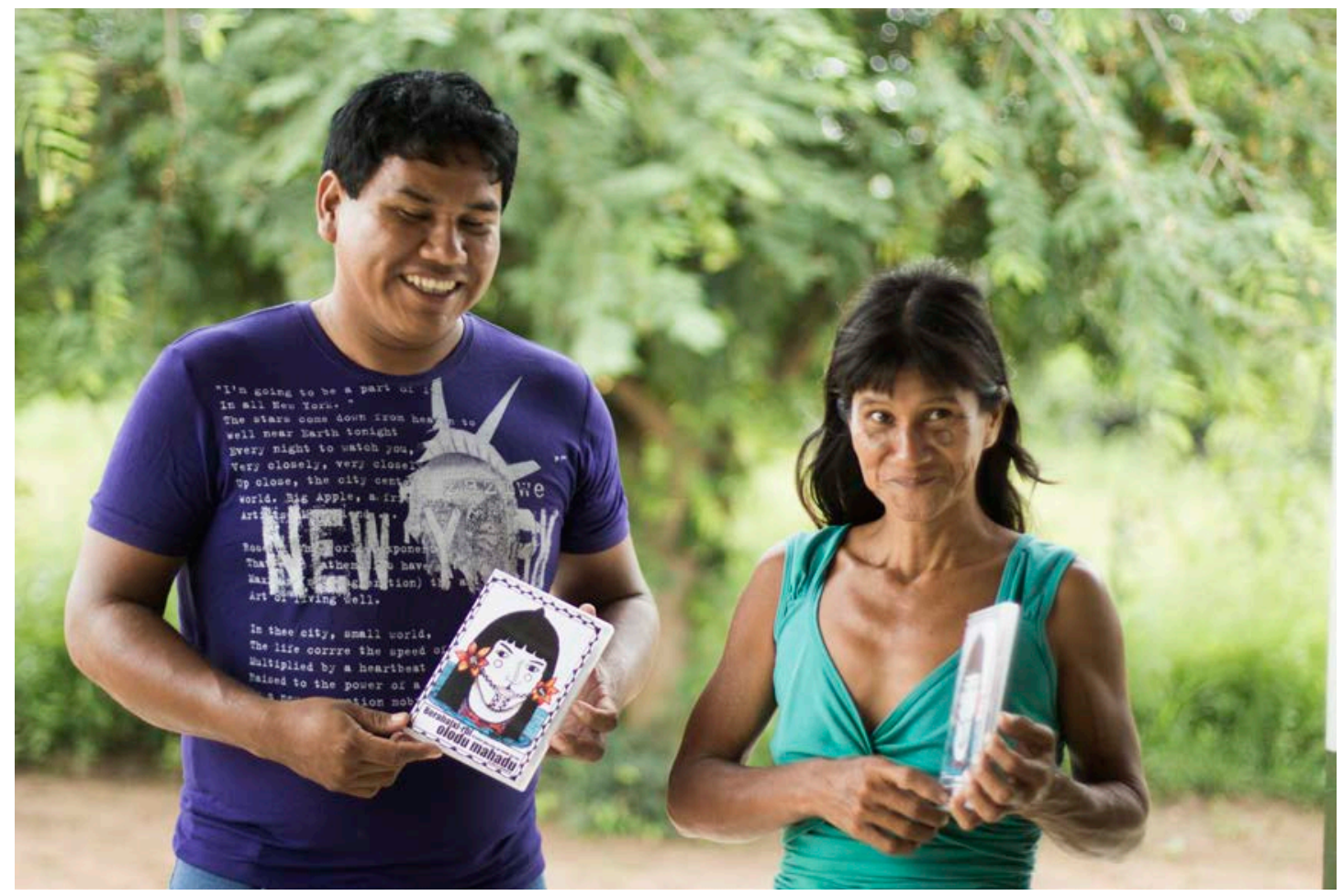

APENDICE X - Juanahú entre o dvd do filme Berahatxi-rbi Olodu Mahadu a Teoworo, cacique da aldeia Fontoura (foto: Caio Lazaneo)

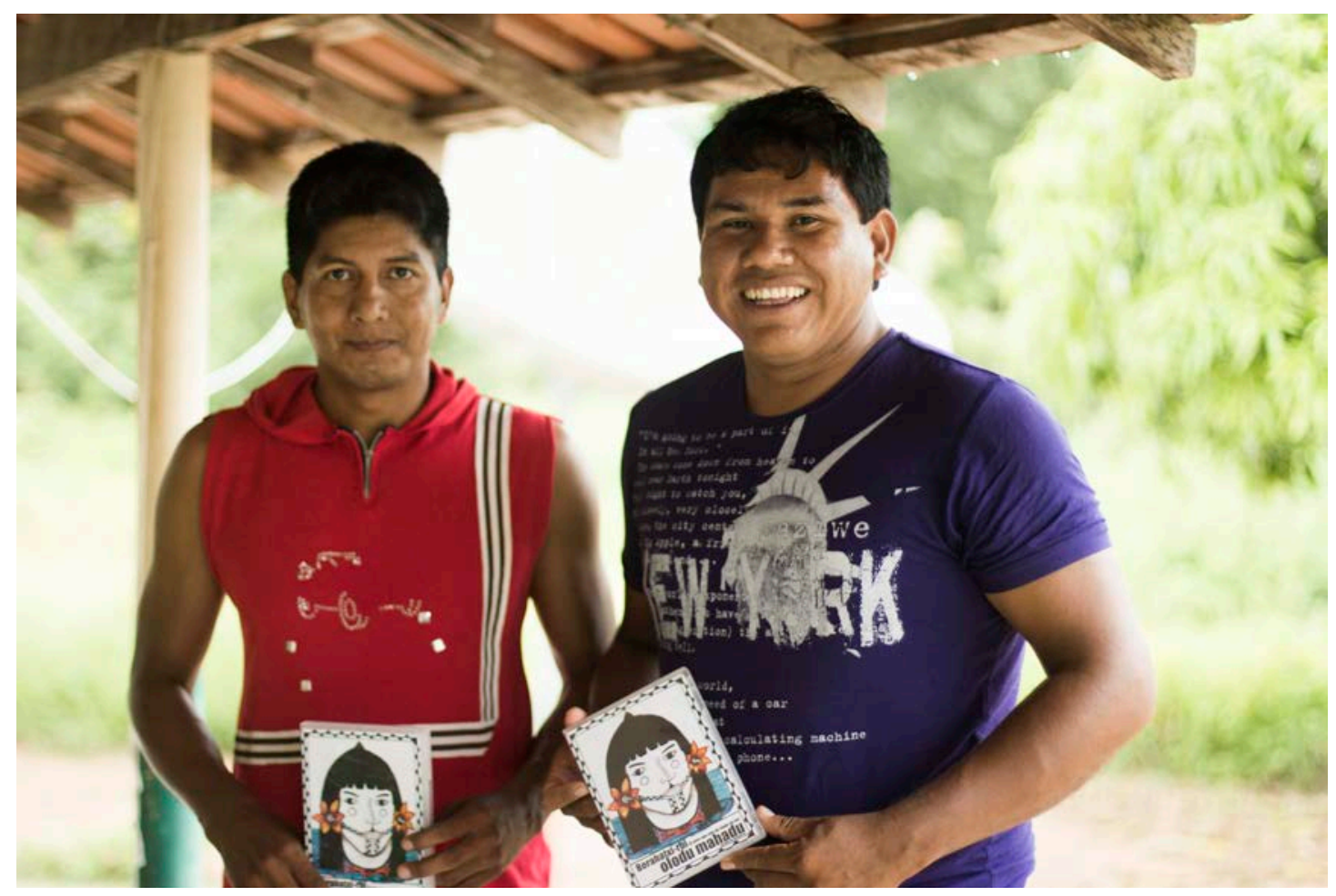


APENDICE Z - Conversas pela aldeia. (foto: Juanahú Iny)

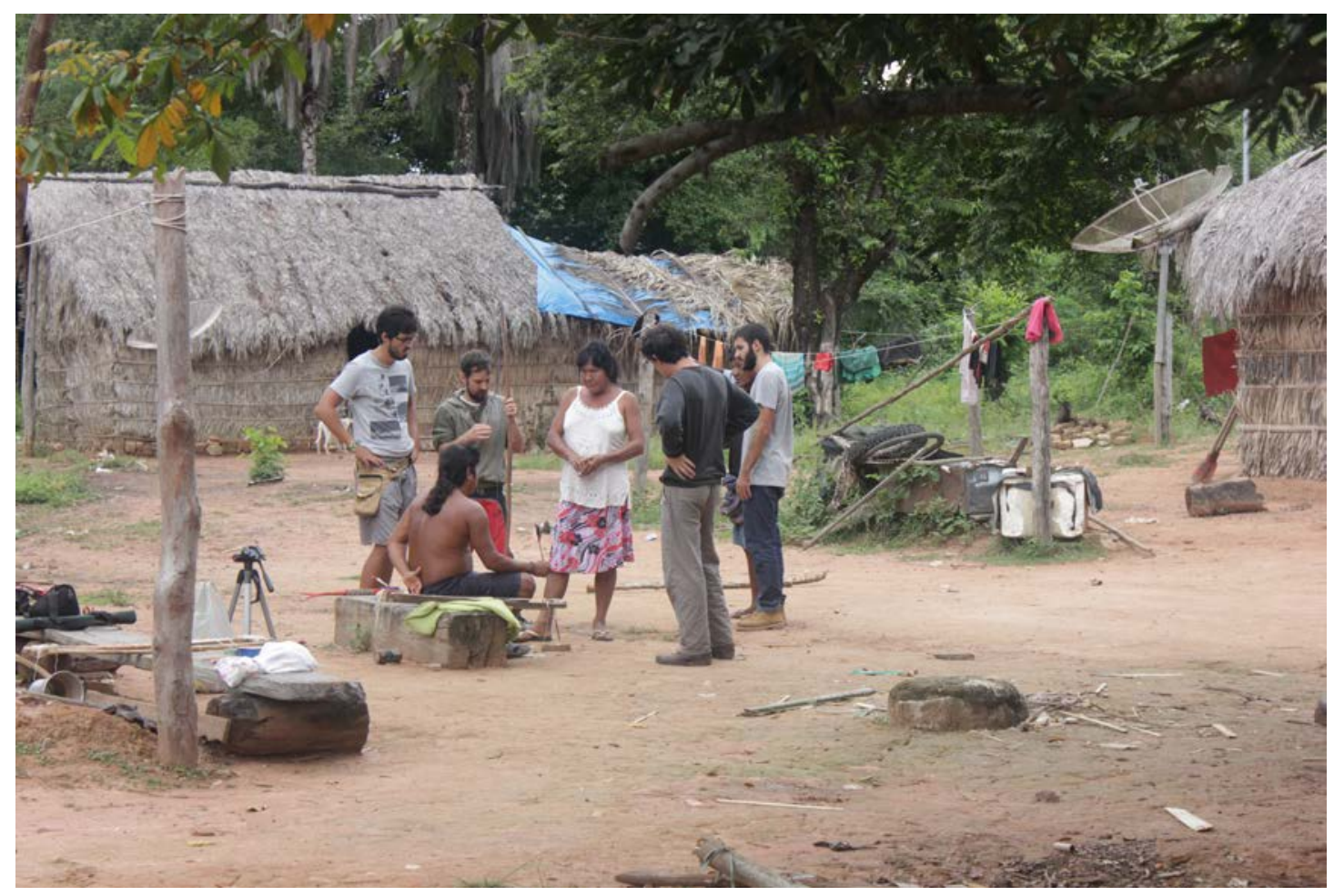

APENDICE A2 - Chegada dos aruanãs. (foto: Juanahu Iny)

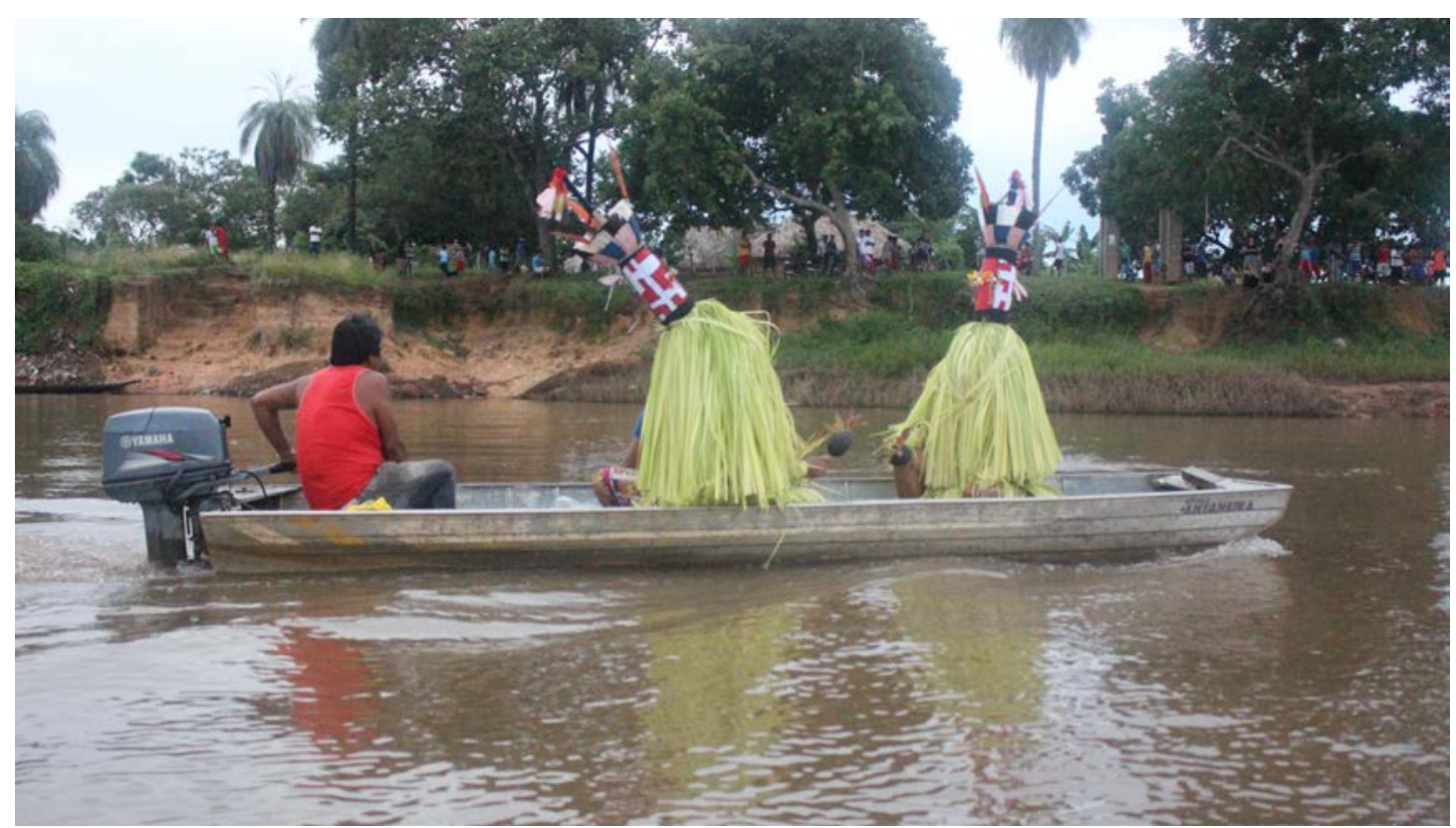


APENDICE B2 - Da esq. Para dir. Yudji Oliveira, Caio Lazaneo, Herenaki, Iexika, e abaixo, Malawiru, (foto: Caio Luiz)

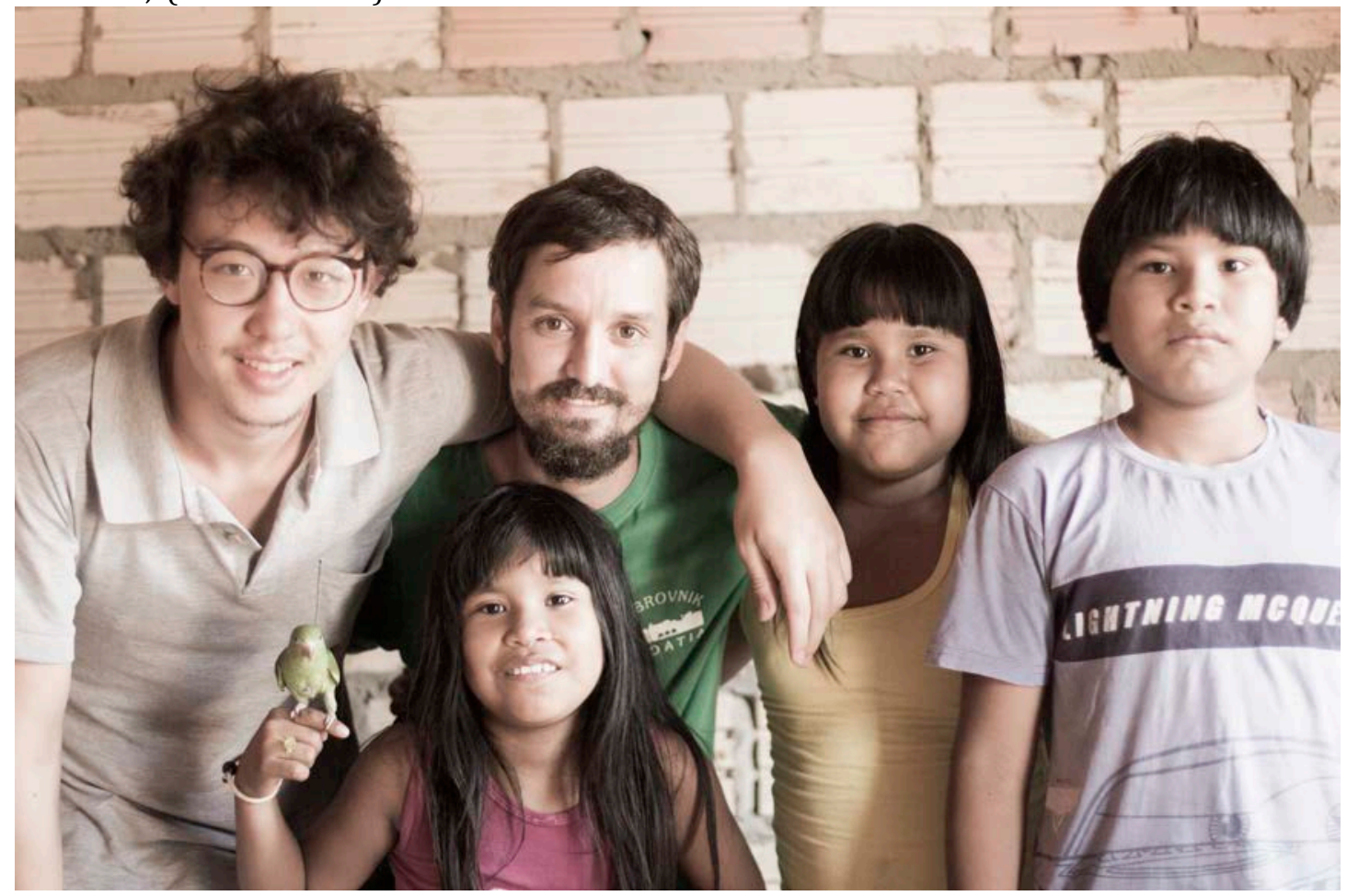

APENDICE C2 - Malawiru e Herenaki sopram o barquinho na poça (foto: Caio Lazaneo)

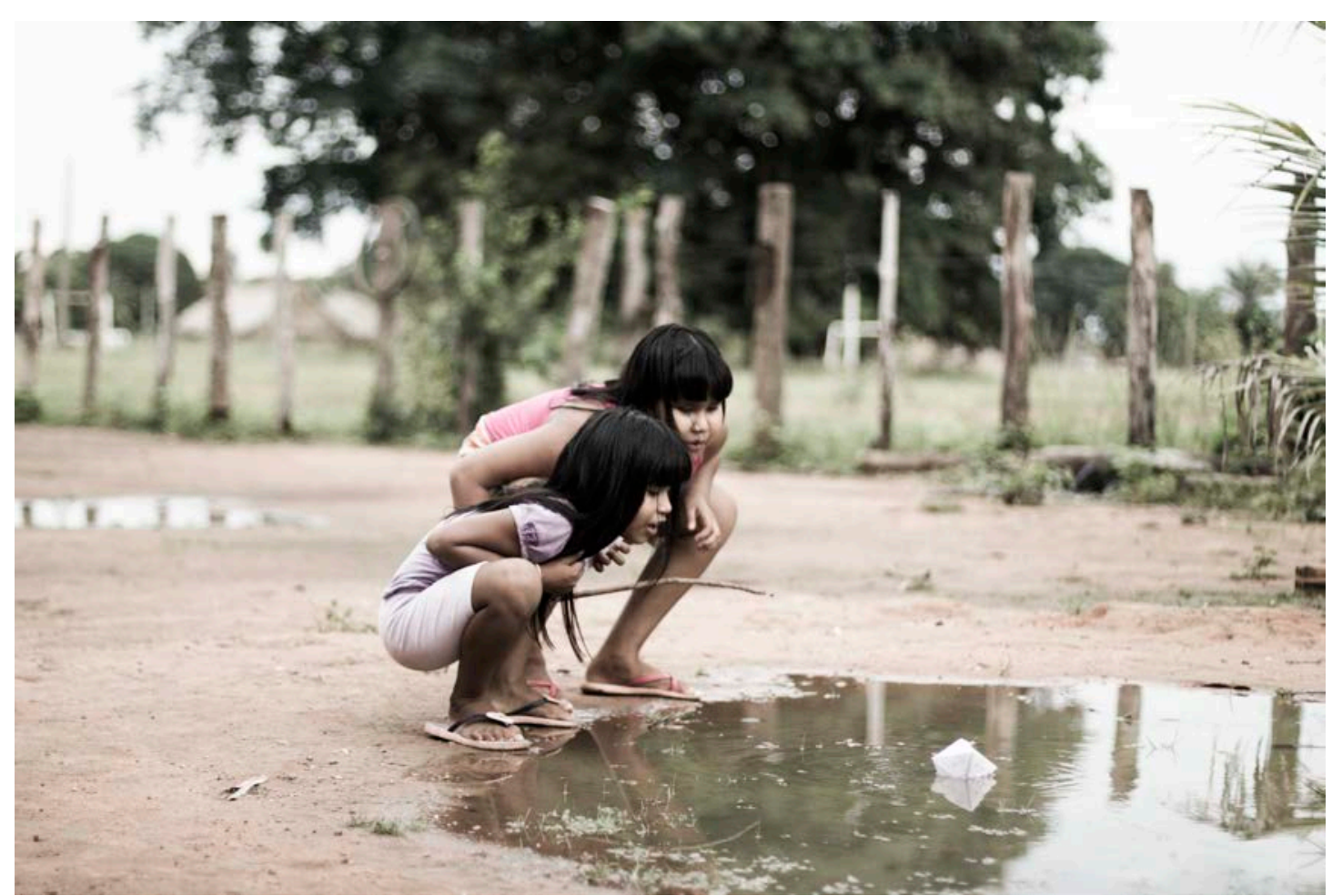


APENDICE D2 - Desenhos de Iexika representando os três amigos que visitaram sua casa durante o mês de janeiro de 2015. (foto: Caio Lazaneo)

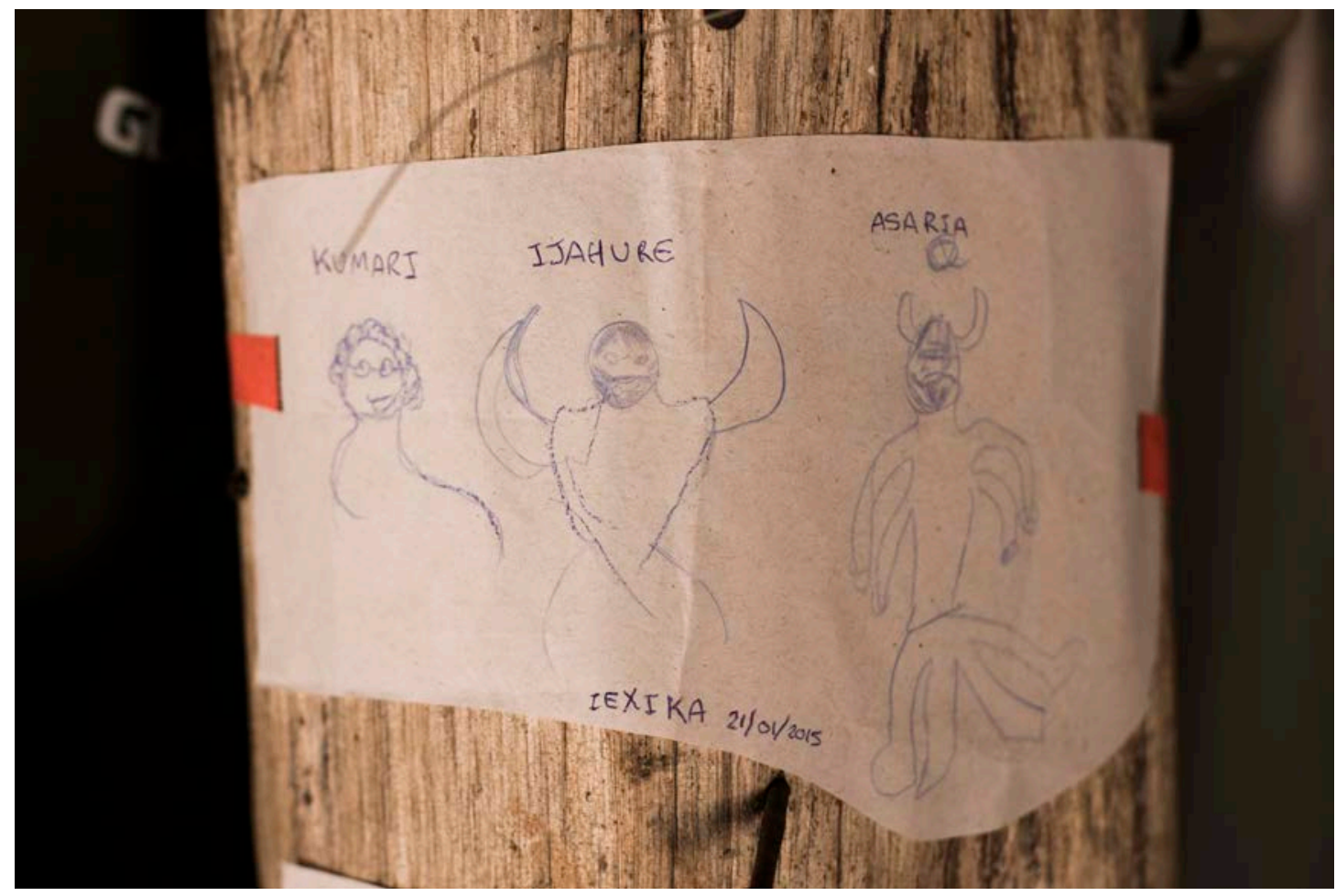

APENDICE E2 - Desenho de Herenaki representando o amigo Asaria (Caio Lazaneo) que visitou sua casa durante o mês de janeiro de 2015. (foto: Caio Lazaneo)

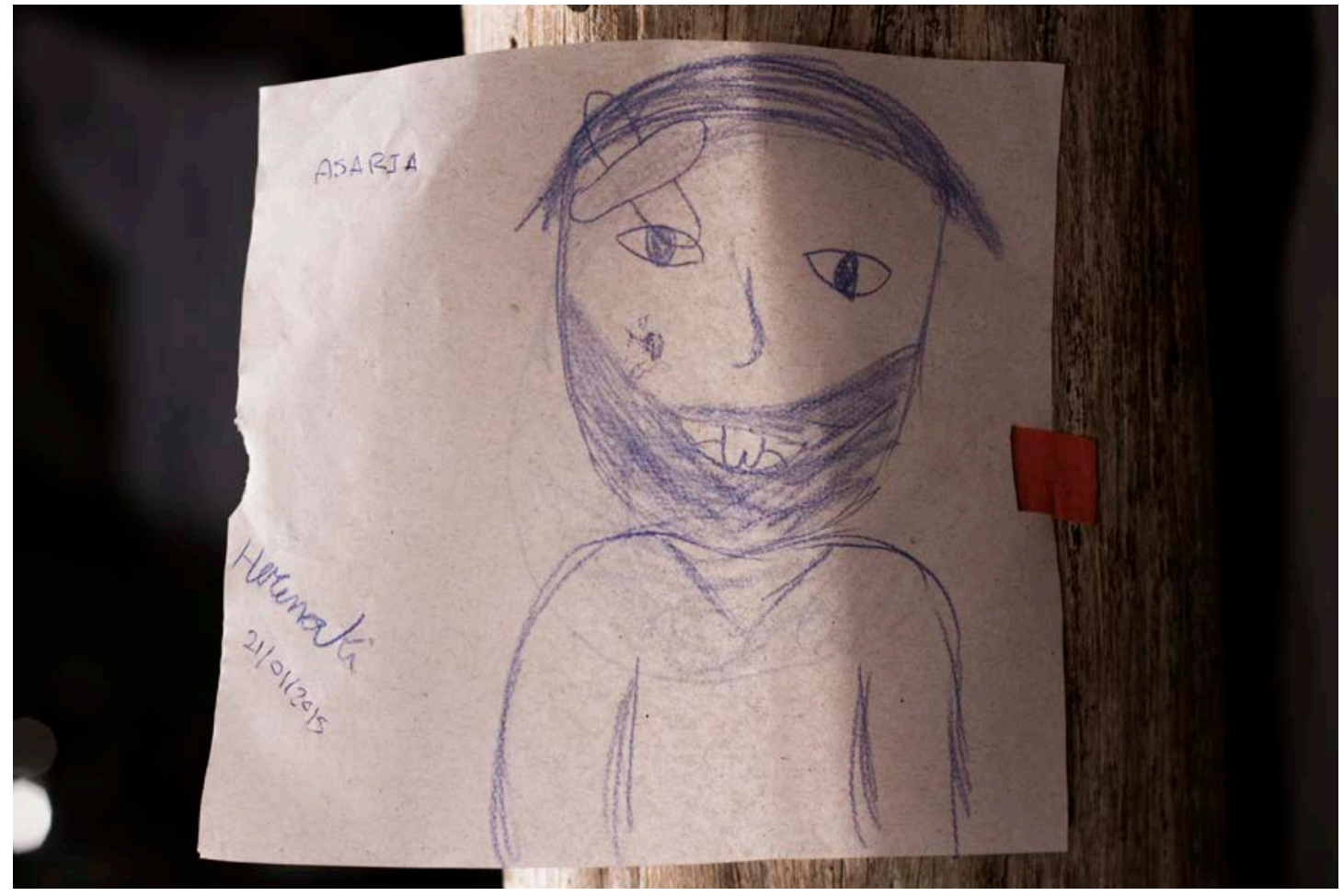


APENDICE F2 - Desenho de Malawiru representando o amigo Asaria (Caio Lazaneo) que visitou sua casa durante o mês de janeiro de 2015. (foto: Caio Lazaneo)

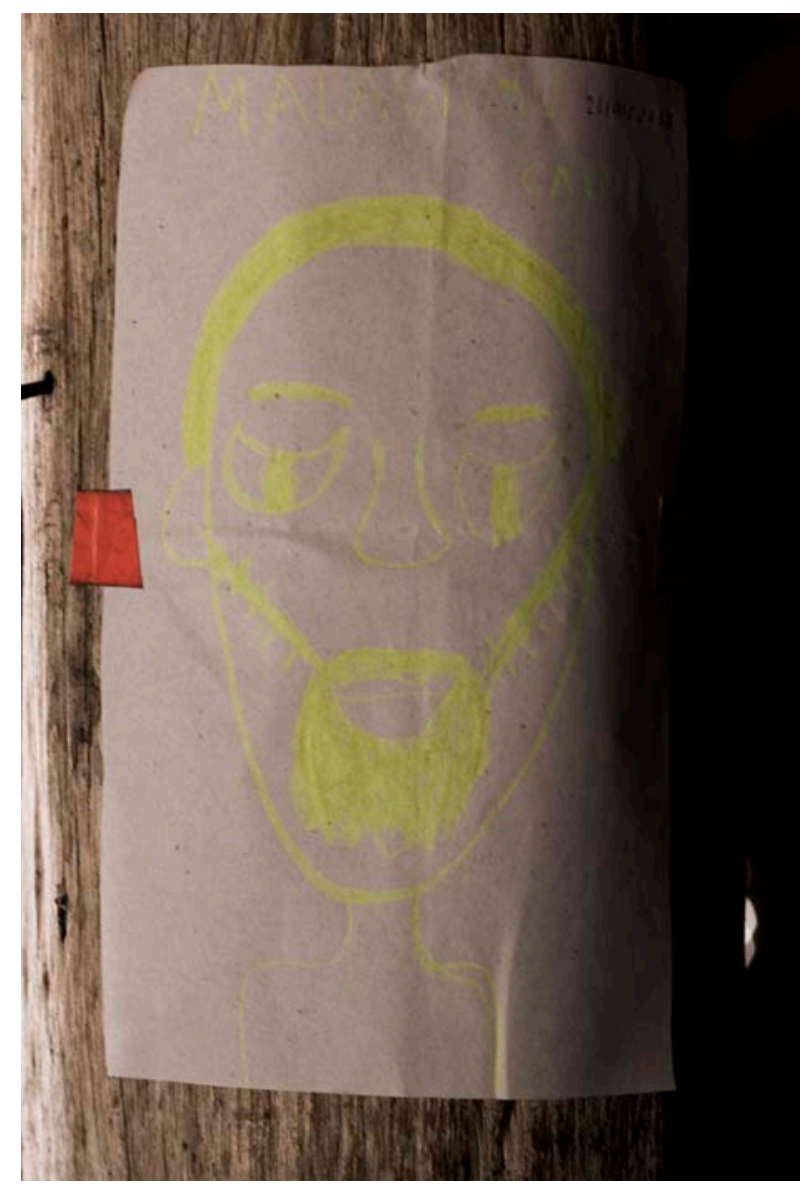

